\title{
The Administrative Risk Decision-making Mechanism regarding the Authorization of GMOs in Germany/the EU and in China
}

\author{
Inaugural-Dissertation \\ zur Erlangung des Grades \\ Doktor der Rechtswissenschaften (Dr. jur.) \\ des Fachbereichs Rechtswissenschaft \\ der Johann Wolfgang Goethe-Universität Frankfurt am Main \\ vorgelegt von \\ Yanni Luo aus Xiangxiang City, Hunan Province (VR China) \\ Frankfurt am Main, \\ November 2021
}


Luo, Yanni

The Administrative Risk Decision-making Mechanism regarding the Authorization of GMOs in Germany/the EU and in China

Dissertation der Goethe-Universität Frankfurt am Main

Erster Gutachter: Prof. Dr. Eckard Rehbinder

Zweiter Gutachter: Prof. Dr. Michael Bothe

Mündliche Prüfung fand am 6. Dezember 2021 statt. 


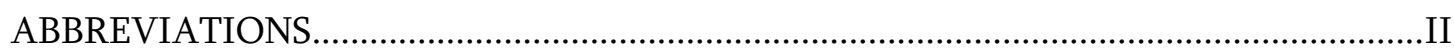

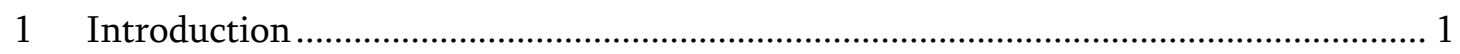

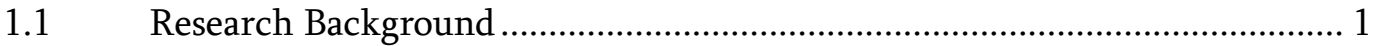

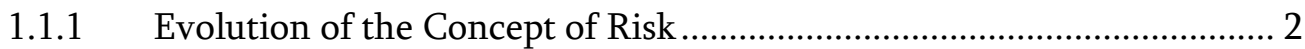

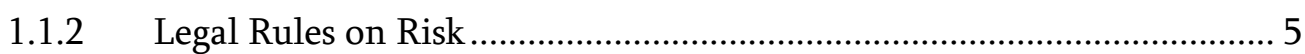

1.1.3 Increased Demand for Ex-ante Intervention......................................... 10

1.1.4 GM techniques as an Example of Uncertain Risk ................................. 13

1.1.5 Dilemma of Decision-making on ex-ante Intervention in GM Risk .... 18

1.2 Research Problem and Structure of Research .............................................. 20

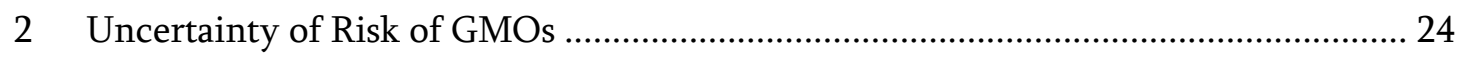

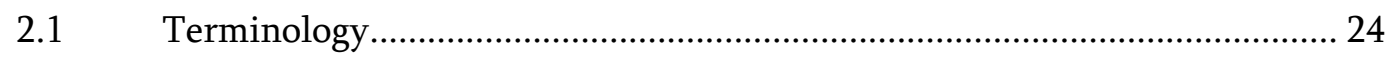

2.1.1 Danger, Risk, Hazard, and Uncertain Risk......................................... 24

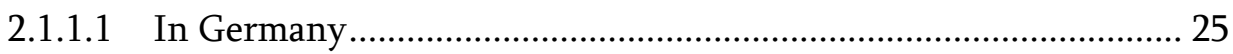

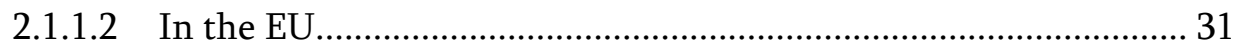

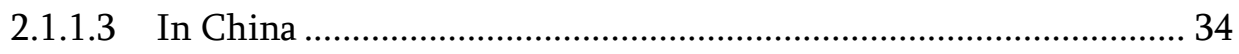

2.1.2 The Administrative Decision-making Mechanism on Risk................... 34

2.2 Characteristic Features of Uncertain Risk of GMOs..................................... 37

2.2.1 Manifestation: Epistemically Uncertain ............................................... 38

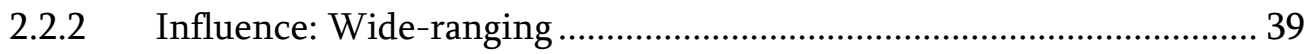

2.2.3 Generation: Manufactured .................................................................... 40

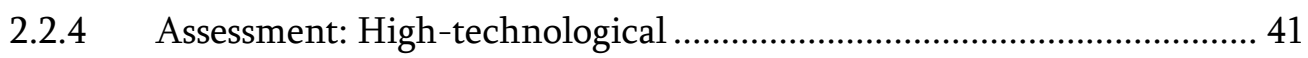

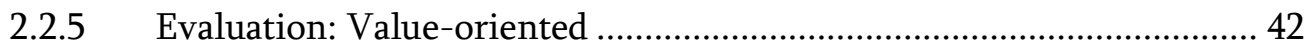

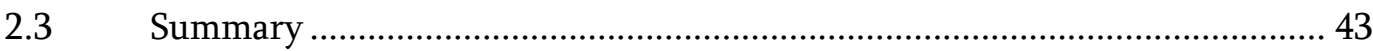

3 Conventional Administrative Decision-making Mechanism Regarding ex-ante

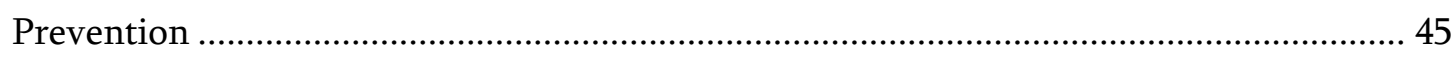

3.1 Danger Prevention as the Legal Task of ex-ante Intervention ..................... 47

3.2 Administrative Decision-making Mechanism on Danger Prevention ......... 48

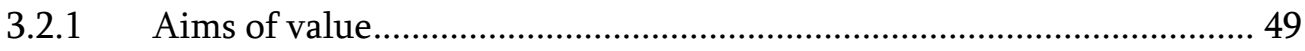

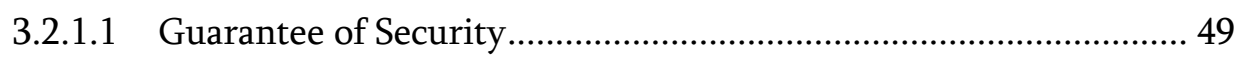

3.2.1.2 Control of the Administration and Protection of Freedom ............ 50

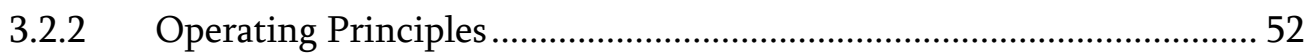

3.2.2.1 Rationality ……................................................................. 52

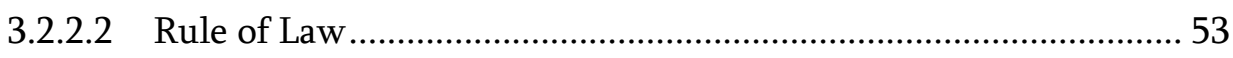

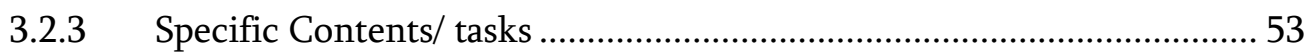

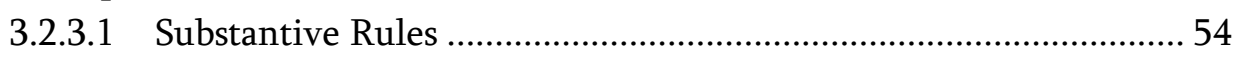

3.2.3.1.1 Cognitive Rule for Factual Rationality ........................... 54

3.2.3.1.1.1 Generation of the Cognitive Reference standard .... 55

3.2.3.1.1.1.1 Relative Stability of Knowledge and Experience 55

3.2.3.1.1.2 The Causal Paradigm 57 
3.2.3.1.1.2 The Content of the Cognitive Reference Standard.. 61

3.2.3.1.2 Rules for Normative Legitimacy....................................... 62

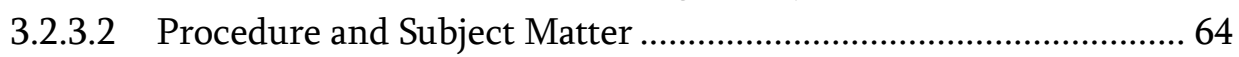

3.2.3.2.1 Identification of the Facts and Prognosis of Damage...... 64

3.2.3.2.2 The Subsumption of Individual Facts under the Norm and

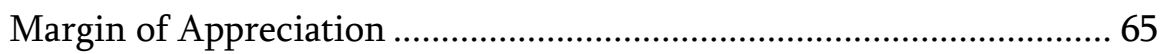

3.2.3.2.3 Determination and Substantiation of Legal Consequences 67

3.3 Summary 67

4 The Challenges to the Conventional Decision-making Mechanism Associated with Uncertain Risk.....

4.1 The Expanded Legal Task of ex-ante Intervention in Risk ........................... 70

4.2 The Challenge to the Conventional Decision-making Mechanism............... 73

4.2.1 The Dilemma of Generating the Cognitive Reference Standard........... 74

4.2.1.1 Relative Dynamics of Risk Knowledge .......................................... 74

4.2.1.2 Partial Failure of the Causal Paradigm in Organizing Risk-related

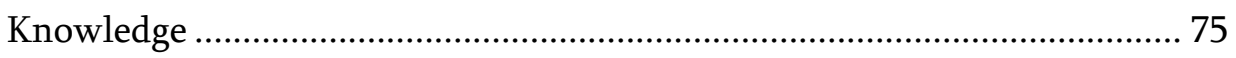

4.2.1.3 The Deficits of Spontaneous Accumulation of Knowledge in

Establishing the Cognitive Reference Standard............................................. 77

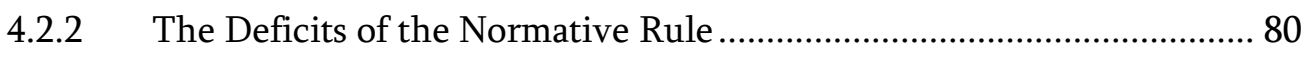

4.2.3 Dilemmas in Procedure ...................................................................... 81

4.2.3.1 Lack of Reliable Information in the Process of Identification and

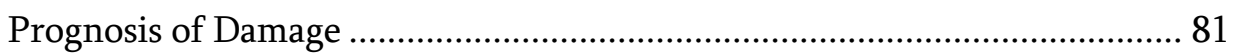

4.2.3.2 Lack of Normative Standards in Subsumption: Extended Margin of

Appreciation but Less Control ..................................................................... 82

4.2.3.3 Incapability to Make a Proportionate Decision............................... 83

4.2.4 The Affected Operating Principles ...................................................... 85

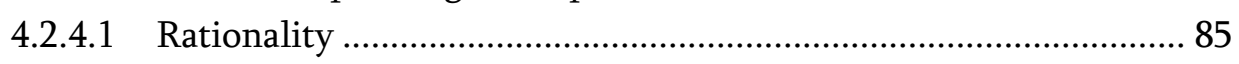

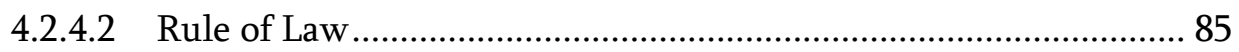

4.2.5 Aims of value: Losing the Equilibrium between Security and Freedom 86

4.3 Summary 87

5 General Legal Response Pertaining to the Administrative Decision-making Mechanism on Risk 89

5.1 Primary Perspectives Reformulating the Administrative Decision-making

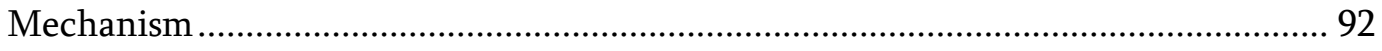

5.1.1 Generation of Knowledge..................................................................... 93

5.1.1.1 Necessity and Function of Generation of Knowledge.................... 93

5.1.1.2 Subordinate Requirements........................................................... 96

5.1.1.2.1 De-materialization of Legislation and Delegation to the

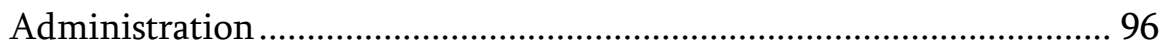


5.1.1.2.2 Multipartite Participation in Collecting Information ..... 99

5.1.1.2.3 Open Procedure for Updating the Information ............ 101

5.1.1.3 Secondary Problems Raised by Generation of Knowledge .......... 101

5.1.1.3.1 Legitimacy and Certainty Problems of the Administrative

Decision 102

5.1.1.3.2 Validity Problems of Generation of Knowledge ........... 103

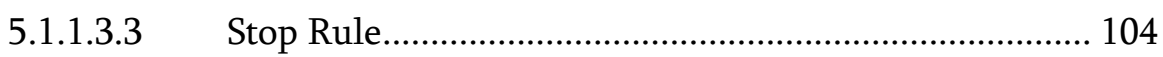

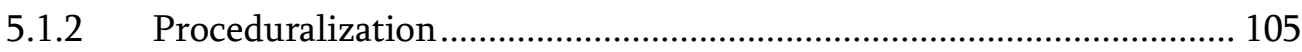

5.1.2.1 Necessity and Function of Proceduralization ............................... 106

5.1.2.1.1 Generation of Knowledge and Stop Rule....................... 106

5.1.2.1.2 Promotion of Reconciliation and Predictability ........... 107

5.1.2.1.3 Compensation for Substantive Control.......................... 108

5.1.2.2 The Subordinate Requirements for Proceduralization................. 110

5.1.2.3 Secondary Problems Raised by Proceduralization ........................ 111

5.2 Theoretical Reformulation of the Administrative Decision-making

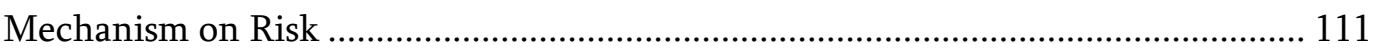

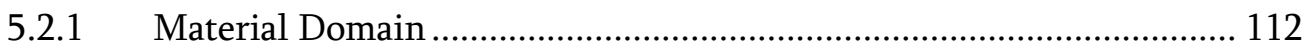

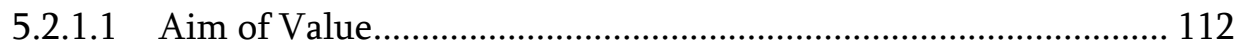

5.2.1.2 Operating Principle: Risk Precaution ............................................ 113

5.2.1.3 The Substantive Rule ................................................................. 115

5.2.1.3.1 Cognitive Reference Standard: The State of Art of Science

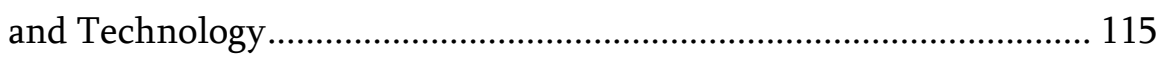

5.2.1.3.2 Normative Rules............................................................. 116

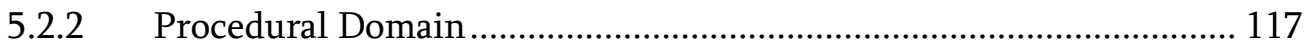

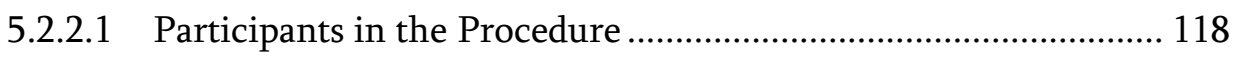

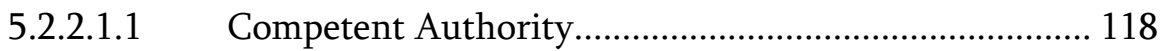

5.2.2.1.2 Professional Experts ......................................................... 119

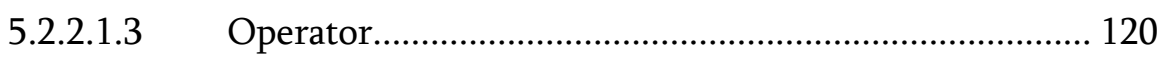

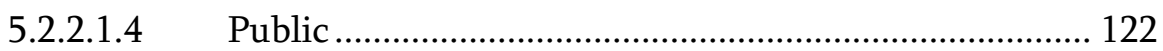

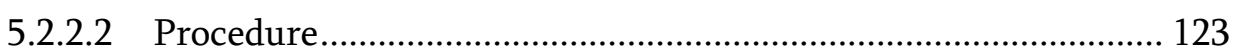

5.2.2.2.1 Risk Assessment ........................................................... 124

5.2.2.2.2 Risk Communication ................................................... 127

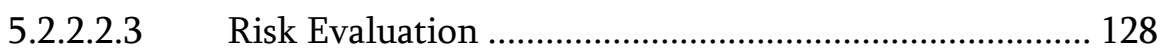

5.2.2.2.4 Risk Management....................................................... 129

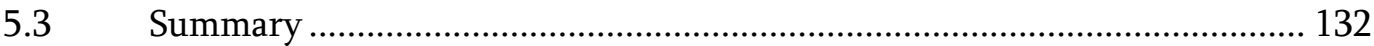

6 Concrete Administrative Decision-making on Risk regarding the Authorization for Agricultural GMOs: Comparing Germany/the EU and China........................................ 134

6.1 Overview of the Regulatory Framework on GMOs ................................... 134

6.1.1 Germany/the EU ................................................................................ 134

6.1.1.1 Basic Regulations of GMOs for General Use............................... 147

6.1.1.1.1 The Regulation at the EU Level: Directive 2001/18/EC 147

6.1.1.1.2 The Regulation at the German Domestic Level: 
6.1.1.2 Basic Regulation of GMOs for Food and Feed Use: Regulation (EC) No $1829 / 2003$ 152

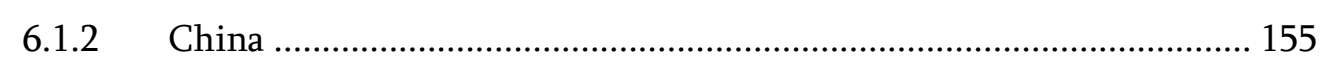

6.1.2.1 Regulation on Management of Safety of Agricultural GMOs...... 161

6.1.2.2 Implementing Administrative Regulations.................................... 163
6.1.2.2.1
ARMSA-AGMO 163
6.1.2.2.2
ARML-AGMO. 164
6.1.2.2.3
AREAP-AGMO 164
6.1.2.2.4
ARMSI-AGMO 165
6.1 .2 .2 .5
ARMIQEE-GM Products 165
6.1.2.2.6
ARMEA-GMF . 165

6.2 The Function of Administrative Risk Decisions on GMOs in the Form of an Authorization 166

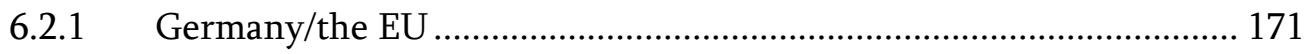

6.2.1.1 Decision-making on GMOs for General Use .............................. 172

6.2.1.1.1 Release of GMOs .......................................................... 172

6.2.1.1.2 Marketing of GMOs ..................................................... 177

6.2.1.2 Decision-making on GMOs for Food and Feed Use ..................... 178

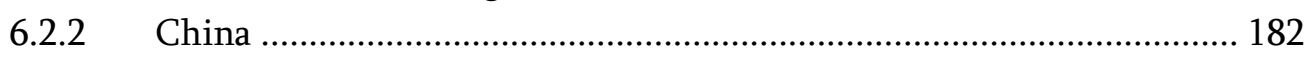

6.3 Procedural Level of Administrative Decision-making on GMO Risks....... 187

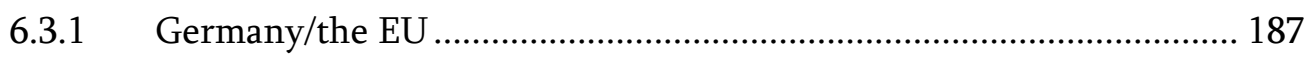

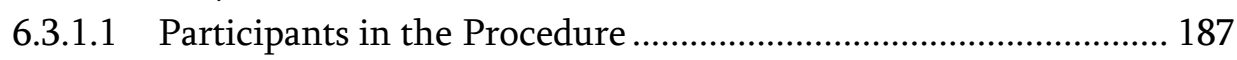

6.3.1.1.1 Competent Decision-making Authority ......................... 188

6.3.1.1.1.1 Release and Marketing of GMOs........................... 188

6.3.1.1.1.2 Marketing of GMOs for Food and Feed Use .......... 189

6.3.1.1.2 Cooperating Decision-making Authorities..................... 190

6.3.1.1.3 Scientific Institute ......................................................... 191

6.3.1.1.3.1 Release and Marketing of GMOs............................ 191

6.3.1.1.3.2 Marketing of GMOs for food and feed use............. 194

6.3.1.1.4 Consulted Institutes ...................................................... 198

6.3.1.1.4.1 Release and Marketing of GMOs............................. 198

6.3.1.1.4.2 Marketing of GMO for Food and Feed Use............ 199

6.3.1.1.5 Applicant ...................................................................... 199

6.3.1.1.5.1 Release and Marketing of GMOs............................ 199

6.3.1.1.5.2 Marketing of GMOs for Food and Feed Use .......... 202

6.3.1.1.6 Public....................................................................... 202

6.3.1.1.6.1 Release and Marketing of GMOs............................ 202

6.3.1.1.6.2 Marketing of GMOs for Food and Feed Use .......... 204

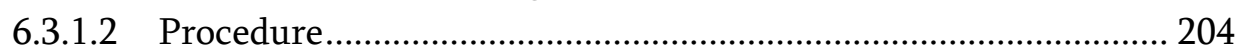

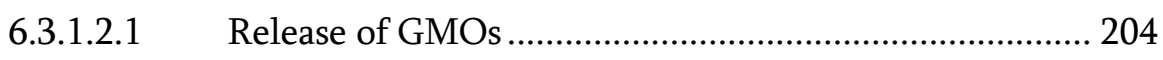

6.3.1.2.1.1 Application Stage................................................... 204

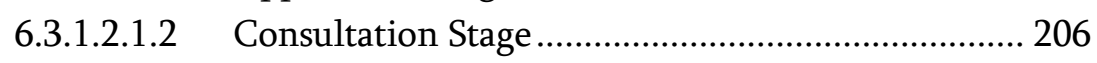




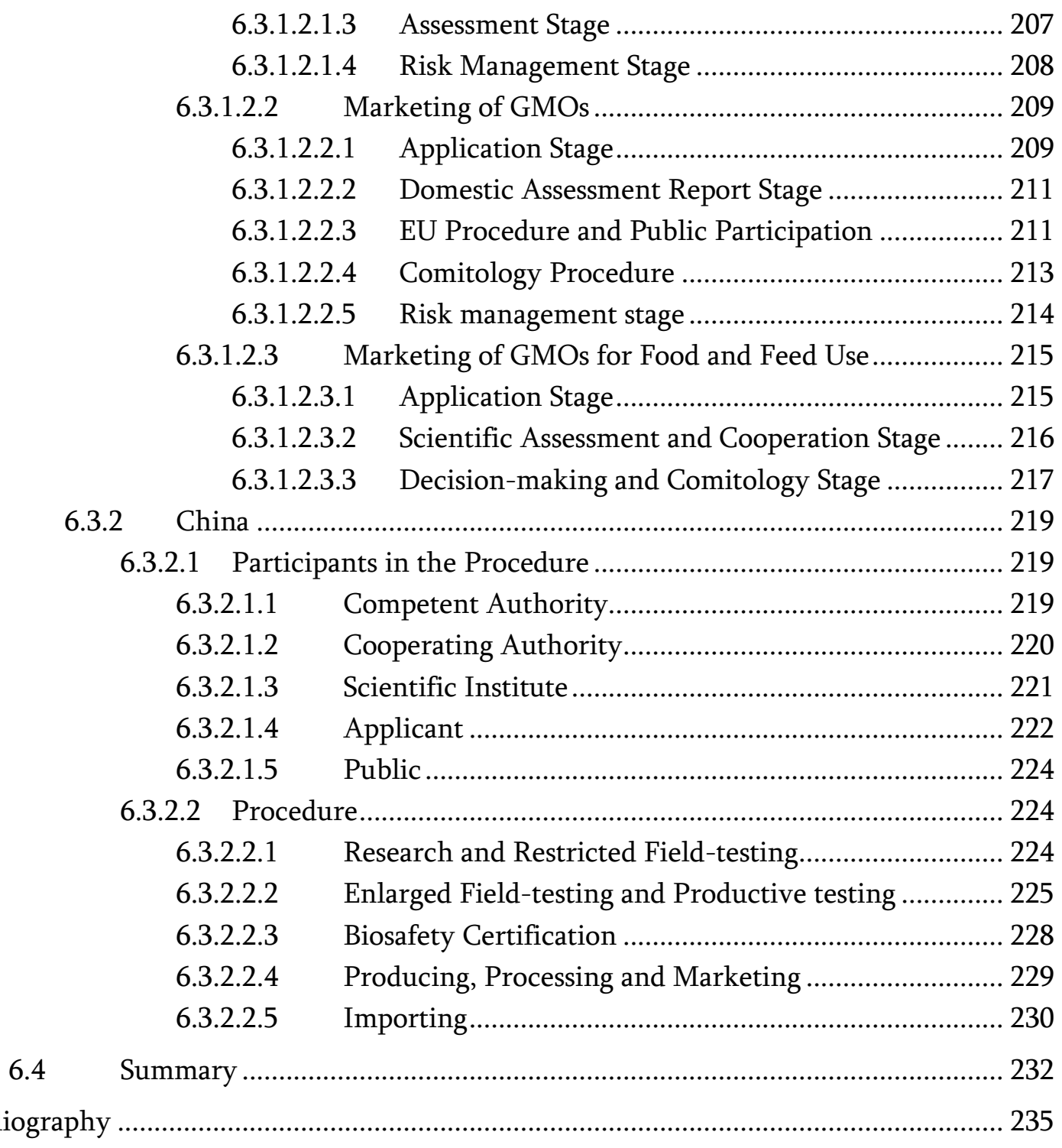




\section{ACKNOWLEDGEMENTS}

I would like to express my sincere gratitude to my doctoral supervisor, Prof. Dr. Eckard Rehbinder, for his great forbearance, profound guidance and meticulous academic help in the past 6 years. Without his help and support, this work would not have been possible. His strict academic attitude will inspire me in my academic future. It is one of the most fortunate experiences of my life to have been his doctoral student.

I am indebted to Prof. Dr. Michael Bothe for the speedy preparation of the second evaluation and constructive suggestions. I would also like to thank Prof. Dr. Tianbao Qin, Prof. Dr. Jianwei Zhang, Ms Jie Feng, Dr. Chujia Zhang, Dr. Hai Li, for their selfless help and support to me.

My heartfelt thanks go to my parents and my husband for their love, encouragement and patience. 


\section{ABBREVIATIONS}

AREAP-AGMO

ARMEA-GMF

ARMIQEE-AGM Products

ARML-AGMO

ARMSA-AGMO

ARMSI-AGMO

Art.

BB

$\mathrm{BfN}$

BfR

BGenTGKostV

BoFG

BSE

$\mathrm{Bt}$

BVerfGE

BVerwGE

BVL

COVID-19

CRISPR

DÖV

DriZ
Administrative Regulation for the Examination and Authorization of Processing of Agricultural GMOs Administrative Regulation of Management of Examining and Approving Methods for Genetic Engineering Activities of Forest

Administrative Regulation for the Management on the Inspection and Quarantine of Entering and Exiting the Territory of the GM Products

Administrative Regulation for the Management of the Label of Agricultural GMOs

Administrative Regulation for the Management of the Safety Assessment of Agricultural GMOs

Administrative Regulation for the Management of the Safe Import of Agricultural GMOs

Article

Betriebs-Berater

Bundesamt für Naturschutz

Bundesinstitut für Risikobewertung

Bundeskostenverordnung zum Gentechnikgesetz

Bureau of Forestry and Grassland

Bovine Spongiform Encephalitis

Bacillus thuringiensis

Bundesverfassungsgericht

Bundesverwaltungsgericht

Bundesamt für Verbraucherschutz und

Lebensmittelsicherheit

Coronavirus Disease 2019

Clustered Regularly Interspaced Short Palindromic Repeats

Die Öffentliche Verwaltung

Deutsche Richterzeitung 
DVB1.

DW

ed(s).

EFSA

EGGenTDurchfG

FAO

FLI

FMD

Food Sci Hum Well

GenTAnhV

GenTAufzV

GenTBetV

GenTG

GenTG

GenTNotfV

GenTPflEV

GenTSV

GenTVfV

GG

GMOs

$\mathrm{Ht}$

i.b.s.

i.n.s.

ISAAA

JKI

KriV

MoA

$\mathrm{NuR}$

NVwZ

PEI

RKI

RMS-AGMO
Deutsches Verwaltungsblatt

Die Verwaltung

editor(s)

European Food Safety Authority

EG-Gentechnik-Durchführungsgesetz

Food and Agriculture Organization

Friedrich-Loeffler-Institute

Foot and Mouth Disease

Food Science and Human Wellness

Gentechnik-Anhörungsverordnung

Gentechnik-Aufzeichnungsverordnung

Gentechnik-Beteiligungsverordnung

Gesetz zur Regelung der Gentechnik

Gentechnikgesetz

Gentechnik-Notfallverordnung

Gentechnik-Pflanzenerzeugungsverordnung

Gentechnik-Sicherheitsverordnung

Gentechnik-Verfahrensverordnung

Grundgesetz

Genetically Modified Organisms

Herbicide-tolerant

in broad sense

in narrow sense

International Service for the Acquisition of Agri-biotech

Julius Kühn Institute

Kritische Viertejahresschrift

Ministry of Agriculture and Rural Affairs

Natur und Recht

Neue Zeitschrift für Verwaltungsrecht

Paul-Ehrlich-Institute

Robert Koch-Institute

Regulation on Management of Safety of Agricultural GMOs 
TFEU

UTR

VerwArch.

Vol.

VVDStRL

VwVfG

WHO

ZAW

ZKBS

ZKBSV

ZUR
Treaty on the Functioning of the European Union

Umwelt und Technikrecht

Verwaltungsarchiv

Volum

Veröffentlichungen der Vereinigung der Deutschen

Staatrechtslehrer

Verwaltungsverfahrensgesetz

World Health Organization

Zeitschrift für allgemeine Wissenschaftstheorie

Zentrale Kommission für Biologische Sicherheit

ZKBS-Verordnung

Zeitschrift für Umweltrecht 
1 Introduction

\subsection{Research Background}

The ongoing worldwide COVID-19 pandemic is a wake-up call that human cannot dominate nature but can only try to live in harmony with it. Simultaneously, uncertain risk, induced by the benefit-oriented, rapidly developing modern technologies, has been prominent in unprecedented dimensions, which has or may cause far-reaching adverse effects on relations between nature, individuals, social structures, and relationships between generations. ${ }^{1}$ It is eminently reified in proliferating public anxiety and a sense of insecurity about the technology. Contemporary biotechnology is a typical exemplification of a phenomenon that can cause significant damage to public safety and security and to nature. While we deal with biotechnology, it is urgent to develop the necessary codes of conduct for the harmonious coexistence of people, nature, and technology.

However, facing the uncertain risk of modern biotechnology, the measures to deal with public safety and security issues are not (entirely) certain and remain (largely) in our cognitive blind spot. The uncertain risks of science and technology, to a certain extent, shake the legitimacy of the operation of the law: on the one hand, the law of risk regulation needs to develop timely and effective measures to underpin public safety, but which kind of means is effective remains to be explored and examined; on the other hand, the law lacks a sufficient empirical basis, and improper legal interventions in the manner of "trial and error" are also likely to create "second-order" institutional risks². These are topics that have been studied by scholars for the past thirty years but are still not fully resolved: the origins of modern risks, the traditional legal response to risks and the challenges GMO uncertain risk posing to the legal system, and the legal responses and the inadequacies of existing laws.

\footnotetext{
1 Murswiek, Die Bewältigung der wissenschaftlichen und technischen Entwicklungen durch das Verwaltungsrecht, VVDStRL Vol. 48 (1990), p. 208.

2 Scherzberg, Risikosteuerung durch Verwaltungsrecht: Ermöglichung oder Begrenzung von Innovationen?, VVDStRL Vol. 63 (2004), p. 214, 219.
} 
How to maintain the rationality of the law itself, this dilemma is still troubling policymakers in all countries. In particular, while old biotechnological issues remain unresolved, such as the social acceptance of GMOs, new ones are emerging, such as geneediting technology CRISPR and synthetic biology. In fact, the technologies applied to GMOs are closely related to newer technologies, which all involve gene editing. Collating, summarizing, and comparing the experiences and lessons learned in GMO risk management should provide guidelines for risk management of new technologies, especially in the administrative risk decision domain.

\subsubsection{Evolution of the Concept of Risk}

When one speaks of uncertainty, it is negatively understood as being synonymous with risk, and the term of security is often mentioned as the opposite side. ${ }^{3}$ However, in the first place, dating back to the $16^{\text {th }}$ and $17^{\text {th }}$ centuries, "risk" was a neutral word with both "benefitdamage" two possible sides and was created mainly due to printing ${ }^{4}$. The word first appeared in sea voyages and maritime trade matters, ${ }^{5}$ indicating that adventures were always associated with risks. ${ }^{6}$ Specifically, the risk was a kind of situation in which a condition or behavior was likely to trigger considerable profits as well as undesirable damages if the event occurs unhindered, i.e., risk condition or risk-related behavior could lead to an uncertain result. Henceforth, all kinds of adventures with the uncertainty of the outcome were expressed as "risk," which intrinsically contains two sides, i.e., goodness and badness. It is intertwined with the social actor's decision to conduct a risk-related behavior and implies the individual's adventurous intent. ${ }^{7}$ In addition, "risk" signified mainly courage instead of a threat in the context of that epoch.

Following the discovery of probability theory, the connotation of the "risk" in the sense of

\footnotetext{
${ }^{3}$ Spiecker gen. Döhmann, Rechtliche Strategien und Vorgaben zur Bewertung von Nichtwissen, in: Hill \& Schliesky (eds.), Management von Unsicherheit und Nichtwissen, 2016, p. 90.

${ }^{4}$ Luhmann, Soziologie des Risikos, 1991, p. 16.

${ }^{5}$ Silveira Marques, Der Rechtsstaat der Risikovorsorge, 2018, p. 54.

${ }^{6}$ Luhmann, Soziologie des Risikos, 1991, p. 17.

${ }^{7}$ Beck, Risikogesellschaft, 1986, p. 28.
} 
having calculable properties evolved. People found out that there are specific regular rules in some incidents, and the frequency of the occurrence of the outcome could be statistically calculated after a longtime observation. Social experience provides the regularity of individual events or adventures ${ }^{8}$, thereby underpinning the calculation of their undesired damages and expected benefits and their occurring probabilities. ${ }^{9}$ Since then, the instrument of probability theory has been created to calculate the occurring probability, which is also applied to identify the risk. As a result, the probability element based on life experience and knowledge gradually becomes a constitutive element of risk that replaces uncertainty. The magnitude of damage and its probability of occurrence becomes two pivotal elements constituting the risk situation/behavior. They are assumed to be calculable, which implies default certainty justified by experience. In fact, the statistics of the probability of risk are not absolutely correct, which still includes uncertainty and the possibility of change, but the probability theory assumes the certainty and correctness of this probability before the difference appears. Indeed, due to lack of empirical evidence or high statistical costs, not all the magnitude of damage and the probability of occurrence of dangerous situations can be calculated so that they might be regarded and accepted as residual risk or as vis major. In this way, uncertainty is gradually disconnected from risk and enters residual risk.

Ultimately, the concept of risk is closely connected with mathematics and statistics ${ }^{10}$ to measure the worth of adventures with known alternatives for action and make a more rational decision, which capacitated society to predict bad affairs. Mathematics and statistics are used as decision techniques for prognosis. ${ }^{11}$ In general, individuals have traditionally made a relatively rational choice based on empirical predictions of "cause-result" causality and the degree/probability of harm. While making a decision, the dangerous situation is

\footnotetext{
${ }^{8}$ Scherzberg, Risiko als Rechtsproblem. Ein neues Paradigma für das technische Sicherheitsrecht, VerwArch. Vol. 84 (1993), p. 493.

${ }^{9}$ Weimer, The Origins of "Risk" as an Idea and the Future of Risk Regulation, European Journal of Risk Regulation Vol.8:1 (2017), p. 11.

${ }^{10}$ Bernstein, Against the Gods: The Remarkable Story of Risk, 1996, p. 1.

${ }^{11}$ Weimer, The Origins of "Risk" as an Idea and the Future of Risk Regulation, European Journal of Risk Regulation Vol.8:1 (2017), p. 13.
} 
either considered as a calculable risk or ignored by the decision-maker as a residual risk. With the aid of risk decision techniques and guidance of risk-related rules, human beings ambitiously take multifarious adventures, exploring nature, improving science, innovating technology, and launching the industrial revolution. Historically, adventurous behaviors with risk, mainly in the form of technological innovation, facilitate us to increase capacity over nature, improve social productivity, increase the general wellbeing, promote the society marching towards modernity, etc. ${ }^{12}$

In modern times, the semantics of risk has evolved into containing more uncertain attributes and imply social "formulated discomfort", ${ }^{13}$ and the scope of risk is continually expanding. In the second half of the 20th century - more precisely, in the late sixties - the risk was already widely discussed, ${ }^{14}$ e.g., a topical example: the discussion about nuclear technology, gene technology, and more recently, synthetic biology. ${ }^{15}$ The modern risk may entail immeasurable potential uncertain destructive power, threatening national security. ${ }^{16}$ Against the backdrop that there are not enough available experience-based quantitative data nowadays, the risks from technology could not be statistically calculated with the instrument of probability theory. However, if they are easily classified as residual risks and ignored, they may cause massive damage. Furthermore, with the development of technology, personal risks have massively evolved into public risks. The issues of uncertain risk continue to come to the fore, so they must be taken seriously, counted, or dealt with. Beck summarized this temporal phenomenon as the advent of risk society, in which the social-political, environmental, and personal risks induced by the momentum of innovation invalidate existing risk-related rules and protective foundations of modern society cumulatively. ${ }^{17}$

\footnotetext{
12 Bernstein, Against the Gods: The Remarkable Story of Risk, 1996, p. 1.

${ }^{13}$ Bonß, Vom Risiko, 1995, p.14; Silveira Marques, Der Rechtsstaat der Risikovorsorge, 2018, p. 53.

${ }^{14}$ Silveira Marques, Der Rechtsstaat der Risikovorsorge, 2018, p. 55.

${ }^{15}$ Bonß, Vom Risiko, 1995, p. 9.

${ }^{16}$ Scherzberg, Risiko als Rechtsproblem. Ein neues Paradigma für das technische Sicherheitsrecht, VerwArch. Vol. 84 (1993), p. 493; Murswiek, Die staatliche Verantwortung für die Risiken der Technik, 1985, p. 79.

${ }^{17}$ Beck, Risk Society and Provident State, in: Scott, \& Wynne, (eds.), Risk, Environment \& Modernity: Towards A New Ecology, 1996, p. 27.
} 
Many disciplines interpret risk separately in their own ways, such as political science, philosophy, sociology, ${ }^{18}$ technology assessment, or psychology. ${ }^{19}$ Since then, the modern risk dialogue has also emerged in these disciplines. The discourse in jurisprudence that focuses on risk control and residual risks is not an exception..$^{20}$ Various substantive terms represent an uncertain risk, such as potential hazard, potential risk, ambiguous risk, unknown risk, ignorance, etc.

\subsubsection{Legal Rules on Risk}

Given that the risks arise from individual personal intent when the outcome of an individual's risky decision endangers their personal interests, the risky outcome is selfsustaining. However, an individual's risky behavior may occasionally damage the interests of others and create insecurity for others. Man's need for security is an anthropological constant. ${ }^{21}$ Therefore, many risk-related rules have emerged to achieve an equilibrium of social interests and keep society in order. In general, whoever is taking a risk must, therefore, expect to suffer loss and be accountable for others' loss. ${ }^{22}$ Regarding that risk may cause injuries to others, some rules for ex-ante prevention as well as the ex-post compensation or indemnification have to be established. To avoid the jungle rule, the state becomes the most crucial security maintainer and legal rule-maker to guarantee social security.

The security obligation and rule-making power of the state come from people's grants. According to those enlightening state philosophical theories, such as Thomas Hobbes and John Locke ${ }^{23}$, man grants sovereignty to an instance and accepts that this instance is to

\footnotetext{
${ }^{18}$ Fehling, Der Umgang mit Unsicherheit in der wirtschaftlichen Analyse des (Öffentlichen) Recht, in: Hill \& Schliesky (eds.), Management von Unsicherheit und Nichtwissen, 2016, p. 203.

${ }^{19}$ Spiecker gen. Döhmann, Rechtliche Strategien und Vorgaben zur Bewertung von Nichtwissen, in: Hill \& Schliesky (eds.), Management von Unsicherheit und Nichtwissen, 2016, p. 90.

${ }^{20}$ Bonß, Vom Risiko, 1995, p. 9.

${ }^{21}$ Preuß, Risikovorsorge als Staatsaufgabe, in: Grimm (ed.), Staatsaufgaben, 1996, p. 523, 526.

22 Murswiek, Die Bewältigung der wissenschaftlichen und technischen Entwicklungen durch das Verwaltungsrecht, VVDStRL Vol. 48 (1990), p. 208.

${ }^{23}$ Köck, Risikovorsorge als Staatsaufgabe, Archiv des öffentlichen Rechts Vol. 121 (1996), p.1.
} 
deploy means of violence exclusively. It is in exchange for peace and order that this instance can preserve and reward. Therefore, peace-keeping and the responsibility of preventing damages are an obligation of that instance. This appears to be the answer to the question of why the state exists. In order to fulfill its tasks, the state establishes many specific institutions: police apparatus, military apparatus, judiciary. ${ }^{24}$ It is a self-evident rule that a modern state's fundamental tasks include: elimination of mutual endangering between individuals, guarantees of collective security, and safeguards of the common goods. ${ }^{25}$ They legitimize the state's internal sovereignty and monopolization of violence in turn. According to a common idea, security has hitherto been defined as a status of absence of danger or threat. ${ }^{26}$ It is necessitated when there are feelings of discomfort or insecurity due to lack of something, such as possession, social conditions, etc. Nevertheless, as one of the oldest, primary, and permanent missions of the state, ${ }^{27}$ the guarantee of security appears to have a continuously varying scope and fulfilling different measures at different times. ${ }^{28} \mathrm{It}$ is molded and characterized by specific diverse social contexts, such as religion, philosophy ${ }^{29}$, and orientations of nations.

Generally, collective security is usually guaranteed in the process of establishing rules and preserving them. Firstly, the legislature will summarize the life experience with the aid of probability mathematics, form epistemological presumptions about the insecurity-causing behavior, probability of occurrence and extent of damage, and the causal connection between them ${ }^{30}$, predicting the future behavior-related factual dangerous outcome. Subsequently, based on former presumptions with relatively reliable certainty, the behavioral rule can be formulated. Behavioral rules are made up of individual acts together

\footnotetext{
${ }^{24}$ Köck, Risikovorsorge als Staatsaufgabe, Archiv des öffentlichen Rechts Vol. 121 (1996), p.2.

${ }^{25}$ Preuß, Risikovorsorge als Staatsaufgabe, in: Grimm (ed.), Staatsaufgaben, 1996, p. 523, 524.

${ }^{26}$ Calliess, Rechtsstaat und Umweltstaat, 2001, p. 151; Isensee, Das Grundrecht auf Sicherheit, 1983, p. 26.

${ }^{27}$ Hermes, Das Grundrecht auf Schutz von Leben und Gesundheit, 1987, p. 148 et seq.; Bull, Die Staatsaufgaben nach dem Grundgesetz, 1977, p. 347.

${ }^{28}$ Möstl, Die staatliche Garantie, 2002, p. 3.

${ }^{29}$ Preuß, Risikovorsorge als Staatsaufgabe, in: Grimm (ed.), Staatsaufgaben, 1996, p. 523, 524.

${ }^{30}$ Hoffmann-Riem, „Anscheingefahr“ und „Anscheinverursachung“ im Polizeirecht, in: Vogel \& Tipke (eds.), Verfassung, Verwaltung, Finanzen, Festschrift für Gerhard Wacke zum 70. Geburtstag, 1972, p. 328; Darnstädt, Gefahrenabwehr und Gefahrenvorsorge, 1983, p. 59, 75 et seq.; Murswiek, Die staatliche Verantwortung für die Risiken der Technik, 1985, p. 382.
} 
with the respective punitive reactions in the circumstances of a behavioral violation. At last, the legislation will grant intervening power to the administration or jurisdiction to enforce the law. In Germany's "public-private dichotomy", when risks endanger individual interests, private law provides the basis for defense and remedy for civil rights and interests; in contrast, public law undertakes the task of preventing and punishing to protect public safety when risks endanger public safety.

Traditionally, demarcated by the temporal caesura line of breaching a norm or legal interest, ${ }^{31}$ the state uses two legal approaches to guarantee social security: (ex-ante) preventive and (ex-post) repressive. ${ }^{32}$ The preventive approach refers to taking action to cut off the causal relationship between the damage action and the "damage consequences" to prevent the realization or expansion of the damage as a consequence of risk. Since some risky actions (freedom) may cause excessive or irreversible damage, the law often authorizes the state or relevant individuals to take (ex-ante) intervention or defense measures to avoid the materialization of damage. These preventive measures are mainly based on public law (such as Danger Prevention in police law), a few on private law (such as Nuisance Abatement Claims in property law). State organizations, such as police and army to which centralized and monopolized power has been conferred, are obliged to take measures to exante intervention in case of particular, prescribed conditions to prevent more extensive or irreversible damage. ${ }^{33}$ In contrast, the ex-post repression (redress) approach refers to the determination of legal consequences in the form of prosecution, punishment, and compensation after the risk has materialized, i.e., after the infringements of order (including criminal offenses, administrative violation, and civil liability). The repressive measure constitutes a results-oriented approach, i.e., specific actions are only taken when the risk of damage is realized. The main areas of law involved are tort liability law, insurance law, and the law on criminal offenses. Admittedly, this dividing line between

\footnotetext{
${ }^{31}$ Möstl, Die staatliche Garantie, 2002, p. 147 et seq.; Stoll, Sicherheit als Aufgabe von Staat und Gesellschaft, 2003, p. 15; Stein, Polizei- und Ordnungsrecht auf einen Blick, 2019, p. 6.

${ }^{32}$ Möstl, Die staatliche Garantie, 2002, p. 147 et seq.; Stoll, Sicherheit als Aufgabe von Staat und Gesellschaft, 2003, p. 15.

${ }^{33}$ Preuß, Risikovorsorge als Staatsaufgabe, in: Grimm (ed.), Staatsaufgaben, 1996, p. 525.
} 
these case groups has not been drawn clearly and is also controversial. ${ }^{34}$ However, this reservation does not hinder the discussion here.

The fact is that broad statutory terms ("unbestimmte Rechtsbegriffe") 35 under public law with an indefinite legal meaning open up a remarkable boundless administrative power of intervention. ${ }^{36}$ Arbitrary discretion of the state is more prominent in ex-ante prevention measures than ex-post repressive ones, as ex-ante measures rely on relatively subjective prediction ${ }^{37}$ and estimation of the possibility of damage rather than objective facts that actually happened. Just as Hobbes assumed, a sovereign can effectively prevent the "endangerment of man by man", but this protection itself is not reliable. ${ }^{38}$ In the times of the liberal constitutional states, the gravity of public regulations to guarantee collective security lies not in the original purpose- security- but more in constraining state arbitrary power and protecting individual freedom. Accordingly, a series of rules and principles were formulated to restrain the state's arbitrary powers, for instance, the rule of law (Rechtsstaat) in Germany. The rule of law establishes manifold legal ties on the sovereign and ultimately creates "security from the guardian of security." 39

In Germany, in order to control the state's ex-ante intervention power and balance security and freedom, the doctrinal concept of danger and the doctrinal theory of "danger prevention" have been constructed since the times of the Prussian Higher Administrative Court. ${ }^{40}$ In a nutshell, the doctrinal theory of danger prevention systematizes the doctrinal

\footnotetext{
${ }^{34}$ Detterbeck, Allgemeines Verwaltungsrecht (17th edition), 2019, p. 159 No. 504; Private law or criminal law is by no means limited to in the results-oriented regulating model. There are also some ex-ante preventive functional measures set up by the legislature to regulating the private relationships, such as formulating prohibitive provisions as ex-ante repressing certain behavior, or granting entitle the individual a right of taking ex-ante action.

35 Wißmann, Generalklauseln, 2008, p. 1 et seq.

${ }^{36}$ Di Fabio, Risikoentscheidungen im Rechtsstaat, 1994, p. 27.

${ }^{37}$ Darnstädt, Gefahrenabwehr und Gefahrenvorsorge, 1983, p. 8 et seq.

${ }^{38}$ Kaufmann, Sicherheit als soziologisches und sozialpolitisches Problem (2nd edition), 1973, p. 56; with further references; Möstl, Die staatliche Garantie, 2002, p.147 et seq.

${ }_{39}$ Preuß, Risikovorsorge als Staatsaufgabe, in: Grimm (ed.), Staatsaufgaben, 1996, p. 526; Isensee, Das Grundrecht auf Sicherheit, 1983, p. 5 et seq.

${ }^{40}$ Ladeur, Risiko und Recht, in: Bechmann G. (ed.) Risiko und Gesellschaft. 1993, p. 209; with further references, Di Fabio, Risikoentscheidungen im Rechtsstaat, 1994, p. 16-24.
} 
requirements for ex-ante intervention activities, ${ }^{41}$ which are valid for legislatures, the executive, and the judiciary. In particular, the administrative decision of ex-ante intervention is bounded by (doctrinal) danger prevention., the "danger" situation is the only subgroup of risk (in the broad sense), which is of legal relevance and can be the object of intervention by the administrative authority (more information in Chapter 3)

The diagram shows the structure of some legal instruments to regulate traditional risks in the times of liberal constitutional states. ${ }^{42}$

\begin{tabular}{|l|l|l|}
\hline & Ex-ante prevention & Ex-post repression \\
\hline Administrative & $\begin{array}{l}\text { danger prevention, authorization, etc. } \\
\text { (police Law, environmental Law) }\end{array}$ & $\begin{array}{l}\text { administrative penalties, } \\
\text { social insurance, etc. }\end{array}$ \\
\hline Criminal law & $\begin{array}{l}\text { endangerment offenses } \\
\text { (Gefährdungsdelikte) }\end{array}$ & $\begin{array}{l}\text { injury pres } \\
\text { (Verletzungsdelikte) }\end{array}$ \\
\hline Civil law & defense claim (Abwehranspruch) & $\begin{array}{l}\text { tort liability, private } \\
\text { insurance }\end{array}$ \\
\hline
\end{tabular}

Upon the liberalization trend, the security task has, therefore, submerged into the background of theoretical interest. ${ }^{43}$ Accordingly, the law assumes the missions of protecting personal interests (freedom) and limiting intervening state power. That is to say, the legal system is designed to balance security and freedom. In Germany, at the level of administrative law, classical police and regulatory law, such as food law and environmental law, are functionally oriented at limiting state intervention. The core regime of administrative law - danger prevention - has a task-describing meaning, whereby the term "danger" signifies the central prerequisite for state intervention. ${ }^{44}$ Therefore, danger performs the function of balancing freedom and security and stabilizing social expectations. The identification of danger depends on acquired knowledge and experience. ${ }^{45}$

\footnotetext{
${ }^{41}$ In fact, the ex-ante prevention mechanism exists also in the private law.

${ }^{42}$ Seiler, Recht und technische Risiken, 1997, p. 57.

${ }^{43}$ Preuß, Risikovorsorge als Staatsaufgabe, in: Grimm (ed.), Staatsaufgaben, 1996, p.523, 524.

${ }^{44}$ Di Fabio, Risikoentscheidungen im Rechtsstaat, 1994, p. 7.

${ }^{45}$ Preuß, Risikovorsorge als Staatsaufgabe, in: Grimm (ed.), Staatsaufgaben, 1996, p. 528.
} 
Here the relationship between order and knowledge is of special significance. More precisely, the function of danger as a stabilizer of social expectations is based on the regular "cause-effect" causality rule provided by knowledge and experience. By referring to "cause and effect" causation with regularity in experience and knowledge, the probability of occurrence and extent of damage existing in the relevant situation can be predicted and assessed. In furtherance of this, it is possible to determine whether the circumstances fall under "danger", and the administration can take corresponding preventive strategies to avoid damages (make a prognostic decision). The implied functional interactive relationship between order and knowledge work for state-guaranteed security. ${ }^{46}$ In developing and implementing legislation, it is crucial to draw on experience at the factual level and anticipate the possibility of damage. However, the lack of experience or knowledge and the inability to predict the possibility of damage are critical reasons for the failure of traditional legal systems under an uncertain risk background. (This is explained in detail in chapter 3)

\subsubsection{Increased Demand for Ex-ante Intervention}

In the context of risk society, there are more and more uncertain risks caused by new technologies such as biotechnology that do not meet the definition of danger, and society lacks of knowledge and experience with the "cause-effect" causal chain and the "product" of damage/probability. According to Wahl and Appel, the reason that the probability of damage and the consequences of damage is uncertain is not that their inherent potential for damage is actually (objectively) low, but that their (operating) rules and natures are not (yet) recognizable by conventional means of knowledge. ${ }^{47}$ The damage potential of an objectively modern risk is not necessarily lower, but in some instances, it is just that humans lack sufficient knowledge so that it is easy to confuse uncertain risk with low-probability risk. The fact that damage from uncertain risks may now involve life, health, and safety and the people fear the unknown has led to a reluctance to wait for ex-post repression after the

\footnotetext{
${ }^{46}$ Preuß, Risikovorsorge als Staatsaufgabe, in: Grimm (ed.), Staatsaufgaben, 1996, p. 523, 524.

47 Wahl \& Appel, Prävention und Vorsorge: Von der Staatsaufgabe zur rechtlichen Ausgestaltung, in: Wahl \& Appel (eds.), Prävention und Vorsorge, 1995, p. 83.
} 
damage from risks has materialized and to a desire for more preventive state intervention. The need for security and ex-ante prevention is becoming active in people's view again, even far more urgently. In addition, the nature of uncertain risk dictates the need for exante intervention measures. (More information in Section 2.2) For example, with the widespread use of technology, the influence of risk has extended from individuals to the public, thus becoming a public risk that endangers public safety and order and needs to be brought under public law regulation. Due to the fact that life experience and scientific findings do not accurately predict cause-effect relationships anymore, considerable irreversible disadvantages and some of them even destructive ones cannot be ruled out, which are not pure imagination, such as nuclear energy, genetic engineering, and nanotechnology. ${ }^{48}$ Here, ex-ante interventions are beneficial to avoid irreversible damage. Furthermore, the complexity of causality in science and technology determines the allocation of duty of care, and ex-post individual imputation often lacks an objective basis. ${ }^{49}$ Therefore, the need for ex-ante prevention has never been more in demand by society to tackle the risk situation, such as in the form of administrative authorization.

However, in the context of a liberal constitutional state, ex-ante preventive measures under public law are strictly bound by the doctrinal concept of danger prevention, i.e., only in danger situations the state can intervene into individual freedom; therefore, danger prevention is unable to cover the uncertain risk posed by modern technology and is not sufficient to meet the public safety needs. By its nature (see section 2.2), the uncertain modern risk is very different from conventional doctrinal "danger", because it is difficult to assess objectively and rationally by law. Therefore, the question is whether "State" responsibility for ex-ante prevention should be expanded. How much absorptive capacity does the law have for handling the conflict material? Can it fulfill its function as the "immune system of society" in this respect? Can the legal instruments assist the state in

\footnotetext{
${ }^{48}$ Ehlers, Verwaltung und Verwaltungsrecht im demokratischen und sozialen Rechtsstaat, in: Ehlers \& Pünder, (eds.), Allgemeines Verwaltungsrecht, 2016, p. 35; Ossenbühl, Vorsorge als Rechtsprinzip im Gesundheits-, Arbeits- und Umweltschutz, NVwZ (1986), p. 163-164; Scherzberg, Risiko als Rechtsproblem. Ein neues Paradigma für das technische Sicherheitsrecht, VerwArch Vol. 84 (1993), p. 490-491.

${ }^{49}$ Köck, Risikovorsorge als Staatsaufgabe, Archiv des öffentlichen Rechts Vol. 121 (1996), p. 2.
} 
efficiently performing its security functions, and at the same time, achieve the protection of individual freedom, such as technological freedom, from the state's arbitrary encroachment under the rule of law? Having removed danger as the balance between liberty and security, how does the law reconfigure this balance under the rule of law?

These are issues that, since the 1985s, have attracted the attention of many legal scholars. ${ }^{50}$ In practice, both in China and Germany, there have been many years of experience with the legislation, and GMOs is a typical example. There is already an abundance of sophisticated literature devoted to these studies in Germany, not China. It has triggered the emergence of new approaches to law and regulation in both theory and practice. Scholarly work on new modes of governance, ${ }^{51}$ risk regulation ${ }^{52}$, responsive regulation ${ }^{53}$, risk precaution, etc., has contributed to rethinking traditional government, law, and regulation. ${ }^{54}$ Theoretically, the doctrinal theory of risk prevention has been created, which expands the scope of administrative intervention from danger to a broad risk. In practice, both in China and the EU, the legislature has contributed to regulating GMOs and laid down ex-ante prevention measures, such as the authorization reservation regarding GMOs. The legislations have been amended and expanded several times.

However, both China and Germany are still encountering a specific dilemma in the administrative risk decision-making mechanism, which manifests itself in that one cannot effectively reach decisions on preventive or precautionary measures. For example, it is still

\footnotetext{
${ }^{50}$ For more information see: Weimer \& Marin, The Role of Law in Managing the Tension between Risk and Innovation: Introduction to the Special Issue on Regulating New and Emerging Technologies, European Journal of Risk Regulation Vol.7: 03 (2016), p. 469; Brownsword \& Yeung (eds), Regulating Technologies: Legal Futures, Regulatory Frames and Technological Fixes, 2008; Wiener, The Regulation of Technology, and the Technology of Regulation, Technology in Society Vol, 26 (2004), p. 483.

${ }^{51}$ For more information see: Sabel \& Zeitlin, Experimentalist Governance in the European Union: Towards a New Architecture, 2010; van Asselt \& Renn, Risk Governance, Journal of Risk Research Vol. 14 (2011), p. 431. ${ }^{52}$ For more information see: Vos \& Everson, Uncertain Risks Regulated, Taylor \& Francis 2008; Weimer, Risk Regulation and Deliberation in EU Administrative Governance-GMO Regulation and Its Reform, European Law Journal Vol. 21 (2015), p. 622; Lee, Beyond Safety? The Broadening Scope of Risk Regulation, Current Legal Problems Vol. 62 (2009), p. 24.

${ }^{53}$ Black \& Baldwin, Really Responsive Risk-Based Regulation, Law \& Policy Vol. 32 (2010), p. 181.

${ }^{54}$ Weimer \& Marin, The Role of Law in Managing the Tension between Risk and Innovation: Introduction to the Special Issue on Regulating New and Emerging Technologies, European Journal of Risk Regulation Vol.7: 03 (2016), p. 469
} 
challenging to obtain commercial authorization for GMOs. ${ }^{55}$ It is normal that some of the applications are denied, and only a minimal number of GMO authorization applications are granted, which means that the legal authorization reservation system may be hindering the development of technology. In the authorization reservation framework, the freedom of development of science and technology is not fully guaranteed because authorization decisions cannot be reached.

As mentioned at the very beginning of this dissertation, while old biotechnological issues remain unresolved, such as the social acceptance of GMOs, new ones are emerging, such as gene-editing technology CRISPR and synthetic biology. GM techniques are a scientific and technological issue that the legal profession has devoted a great deal of attention to since the 1990s. Both China and the European Union have nearly 30 years of legislative experience in this area. Despite three decades of experience, GM technique still faces difficulties in administrative decision-making and a lack of public acceptance. While the GM technique issue is still unresolved, the EU is already focusing on synthetic biology ${ }^{56}$. A reflection on the decision-making mechanism on GMOs may be helpful to provide lessons also for the regulation of synthetic organisms.

\subsubsection{GM techniques as an Example of Uncertain Risk}

2021 represents the $27^{\text {th }}$ year of worldwide marketing of genetically modified (GM) crops since the approval of the Bt potato with transgenic technology ${ }^{57}$ in 1995 by the U.S. Food

\footnotetext{
${ }^{55}$ Schubert, Zwanzig Jahre Gentechnikgesetz - eine Erfolgsgeschichte? NVwZ 2010, p. 871.

${ }^{56} \mathrm{EU}$ activities on synthetic biology, available at:

https://ec.europa.eu/search/?queryText=Synthetic+Biology\&query source=europa default\&filterSource=europ a default\&swlang=en\&more options language=en\&more options $f$ formats=\&more options date $=$ Last Visit in $15^{\text {th }}$ July 2021.

57 To be clarified, the first commercial cultivation approval of GM crops was granted in 1992 for transgenic tobacco in China, and first American approval was in 1994 for transgenic Flavr Savr Tomato containing delayed ripening characteristics. Nevertheless, considering that American transgenic tomatoes were withdrawn from the market shortly after the entrance and the commercialization of GM crops in large scale and densely was ushered after the USA approval of Bt potato, the scholars hence regarded the year of 1995 as a banner year. For more historical information see: Zhang, Wohlhueter, \& Zhang, Genetically modified foods: A critical review of their promise and problems. Food Sci Hum Well Vol. 3: 5 (2016), p. 116; Bruening \& Lyons, The case of the FLAVR SAVR tomato. California Agriculture Vol.54: 4 2000, p. 6. see: http://calag.ucanr.edu/Archive/?Art.=ca.v054n04p6; Clive \& Anatole, Global Review of the Field Testing and
} 
and Drug Agency, and thereby it has been witnessed the comprehensive advent of substantial and rapid application of the transgenic technique in various species. ${ }^{58} \mathrm{GM}$ technology can be applied to a wide range of fields. Generally, these fields can be divided into three broad categories, based on their intended functions, namely, application in connection with humans (so-called red GM techniques), application in relationship with pharmacy (so-called white GM techniques), and application in contact with food, agriculture and waste management (so-called green GM techniques). 59 "Brown" stands for wastewater treatment and "yellow for natural resource modification. There are currently four categories of all GM crops, almost accounting for $99 \%$ of their cultivating hectarage in the world, i.e., soy, corn, cotton, and canola. ${ }^{60}$ The countries capable of exporting sufficient agricultural products, e.g., the United States, Brazil, and Argentina ${ }^{61}$, mainly engage in GM agriculture, and GM technology adoptions in the US are over $90 \%$ for the principal crops of maize (92\% adoption), soybean (94\%), and cotton (94\%). ${ }^{62}$

Concluding from the statistical figures, GM technologies are undoubtedly associated with extensive economic benefits and ecological prospects. ${ }^{63}$ In 2016, the global area of biotech/GM crops $^{64}$ had reached 189.8 million hectares ${ }^{65}$, economically benefiting from the

Commercialization of Transgenic Plants: 1986 to 1995, International Service for the Acquisition of Agri-biotech 1996; Christoph Then, 30 years of genetically engineered plants -20 years of commercial cultivation in the United States: a critical assessment, 2013. See:

https://www.testbiotech.org/sites/default/files/TESTBIOTECH\%20Cultivation_GE_\%20plants_US.pdf;

Brookes \& Barfoot, Environmental impacts of GM crop use 1996-2016: impacts on pesticide use and carbon emissions. GM Crops \& Food Vol. 9:3 (2018), p. 1.

${ }^{58}$ Brookes \& Barfoot, Environmental impacts of GM crop use 1996-2016: impacts on pesticide use and carbon emissions. GM Crops \& Food Vol. 9:3 (2018), p. 2.

${ }^{59}$ Kloepfer, Umweltrecht, 2016, § 18 No. 82 et seq.; Kauch, Gentechnikrecht, 2009, No. 14.

${ }^{60}$ Clive, Global Status of Commercialized Biotech/GM Crops: 2014. ISAAA brief No. 49. International Service for the Acquisition of Agri-biotech Applications (ISAAA) 2015, Ithacak, NY.

${ }^{61}$ Clive. Global Status of Commercialized Biotech/GM Crops: 2014. ISAAA brief No. 49. International Service for the Acquisition of Agri-biotech Applications (ISAAA) 2015, Ithacak, NY. The US is still the largest cultivator, accounting for $40.3 \%$ (73.1 million hectares) of the global area under GM crops in 2014. Brazil grows $23.3 \%$ (42.2 million hectares), and Argentina 13.4\%.

62 ISAAA Brief 51-2015: Executive Summary

See: https://www.isaaa.org/resources/publications/briefs/51/executivesummary/

${ }^{63}$ Baram \& Bourrier (eds), Governing risk in GM agriculture, 2010, p. 7.

${ }^{64}$ Although the application domains of GM techniques are far more than in agricultural crops, considering that GM crops are the ones attracting the most public attention and concern and they are directly related to our daily lives, this Art. thus focuses on the representative subjects, GM crops.

${ }^{65}$ ISAAA, Global Status of Commercialized Biotech/GM Crops in 2017: Biotech Crop Adoption Surges as Economic Benefits Accumulate in 22 Years. ISAAA Brief No. 53. ISAAA 2018, Ithaca, NY. See: http://www.isaaa.org/resources/publications/briefs/53/ 
fact that biotechnology has significantly accelerated income increase of growing farms, collectively accounting nominally to $\$ 186.1$ billion from 1996 to $2016 .{ }^{66}$ Besides, they are exceptionally environmentally friendly in many, even though arguably not in all respects. With the aid of GM techniques, fuel use of aggregate 10,925 million liters has been reduced, and additional soil carbon sequestration has occurred every year, reducing the amount of GM crop-related carbon dioxide emission to roughly 29,169 million $\mathrm{kg}$, equivalent to the emissions of the utilization of 16.75 million cars. ${ }^{67}$

All those economic or eco-friendly merits stem from diverse GM traits/methods ${ }^{68}$, which generate different functions. Up to date, GM crops marked with two of these traits, namely herbicide tolerance and insect resistance ${ }^{69}$, make up approaching 99\% of all GM crop planting hectares, contributing to yield and quality improvement by inhibiting pests and disease and creating herbicide resistance. ${ }^{70}$ No more than $1 \%$ of GM crop ${ }^{71}$ areas express some other traits, like virus resistance, tolerance of drought, salinity or cold tolerance, nutritional enhancement, producing recombinant pharmaceutical proteins (molecular farming), etc. ${ }^{72}$ Regarding other traits in non-crop GMOs, such as GM vaccine ${ }^{73}$, there is

\footnotetext{
${ }^{66}$ Brookes \& Barfoot, Environmental impacts of GM crop use 1996-2016: impacts on pesticide use and carbon emissions. GM Crops \& Food Vol. 9:3 (2018), p. 2.

${ }^{67}$ Brookes \& Barfoot, Environmental impacts of GM crop use 1996-2016: impacts on pesticide use and carbon emissions. GM Crops \& Food Vol. 9:3 (2018), p. 11.

${ }^{68}$ Some typical characters in GM crops include delayed ripening, resistance to insecticide, herbicide, drought, black spot, viral disease, and fusarium infection. See: Ge et al, Modeling the optimal strategies for mitigating genetically modified (GM) wheat contamination risks. Conference: 2016 Agricultural and Applied Economics Association. Boston. p.1.

${ }^{69}$ Herbicide-tolerant $(\mathrm{Ht})$ crops are engineered to survive applications of particular herbicides, which would otherwise kill the crop plants. This means that the herbicide can be applied on an entire field, killing the weeds but leaving the GM crop standing. Monsanto's GM "Roundup Ready" crops, which are genetically engineered to tolerate applications of the company's glyphosate-based herbicide, "Roundup", are the most common Ht crops today. Insect-resistant crops are engineered with a gene from the bacteria Bacillus thuringiensis (Bt), which is toxic to some insects. GM Bt plants are engineered to synthesize Bt endotoxin in their cells, making the entire plant toxic to some above- and/ or below-ground insects such as butterflies and beetles. See: Canadian Biotechnology Action Network (CBAN) report: Where in the world are GM crops and foods? March 19, 2015, see: https:/gmoinquiry.ca/wp-content/uploads/2015/03/where-in-the-world-gm-crops-foods.pdf

${ }^{70}$ Dadgarnejad, Kouser \& Moslemi, Genetically Modified Foods: Promises, Challenges and Safety Assessments, Applied Food Biotechnology Vol. 4:4 (2017), p.193.

${ }^{71}$ Clive. Global Status of Commercialized Biotech/GM Crops: 2014. ISAAA brief No. 49. International Service for the Acquisition of Agri-biotech Applications (ISAAA) 2015, Ithacak, NY.

72 World Health Organization. Food, genetically modified. Available from: http://www.who.int/topics/foodgeneticallymodified/en/

${ }^{73}$ As for GM vaccine example, Dengvaxia, an authorized live attenuated GMO vaccine in the EU, is used to avoid dengue disease brought about by dengue virus serotypes 1, 2, 3 and 4 .
} 
currently no comprehensive global statistical description for those. Thanks to these technologies, the conductive functions of low $\operatorname{cost}^{74}$, higher yields ${ }^{75}$, and improvement of nutritional content ${ }^{76}$ in the same crops, and the most critical reduction of mortality and malnutrition, as well as, at least to a significant extent, environmental protection ${ }^{77}$, etc., have been/ will be achieved. ${ }^{78}$

As estimated, a roughly 70\% expansion of the food supply is required to bolster the expected 10 billion worldwide population by $2050^{79}$. The food crisis still exists in some developing countries presently, with presumably 108 million people suffering from subsistence problems ${ }^{80}$. The United Nations $(\mathrm{UN})$ has recognized the importance of establishing enabling mechanisms to promote the sustainable application of biotechnology, inter alia, for developing countries. ${ }^{81}$ Under these circumstances, the advantages of GM technology should be fully utilized under rational, compelling, and legitimate conditions to support the rising populations and a future below the poverty level.

While recognizing the demonstrated fascinating advantages of GMOs in various countries

\footnotetext{
${ }^{74}$ Such as lowering chemical insecticide consumption. See: Alberts van Zyl \& Gelderblom, Biologically Based Methods for Control of Fumonisin-Producing Fusarium Species and Reduction of the Fumonisins, Front Microbiol Vol. 7 (2016), p. 1.

${ }^{75} \mathrm{GM}$ maize expressing crystal (cry) proteins from Bacillus thuringiensis ( $\mathrm{Bt}$ ) to diminish insect damage and fumonisin infection in comparison to non-GM counterparts, therefore, the production is largely imporved. See: Alberts, van Zyl \& Gelderblom, Biologically based methods for control of fumonisin-producing fusarium species and reduction of the fumonisins, Front Microbiol Vol. 7 (2016), p. 1.

${ }^{76}$ Such as GM Vitamin-A-enhanced rice called "Golden Rice", it can provide the nutrient Vitamin-A in the rice, which is lack in conventional rice. See: CBAN's factsheet, January 2014.

See: www.cban.ca/GoldenRiceFactsheet

${ }^{77}$ Results of a 2-year field study with Bt Shanyou 63 in Wuhan suggested that planting of Bt rice can reduce pesticide spraying by $50-60 \%$ compared to non-Bt rice, and that Bt rice could increase rice yield by $60-65 \%$ compared with non-Bt rice when no insecticide was applied. See: Wang et al, Influence of transgenic hybrid rice expressing a fused gene derived from cry1 Ab and cry1Ac on primary insect pests and rice yield, Crop Protection Vol. 29 (2010), p.128.

78 Aerni, Agricultural biotechnology and public attitudes: an attempt to explain the mismatch between experience and protection, in: Ronald, Ross \& Watson, VRP (eds), Genetically modified organisms in foods production, safety, regulation and public health, Elsevier 2015, p. 149.

${ }^{79}$ Lee, et al., Breeding crops to feed 10 billion, Nature Biotechnology Vol.37 (2019), p. 744.

80 ISAAA, Global Status of Commercialized Biotech/GM Crops in 2017: Biotech Crop Adoption Surges as Economic Benefits Accumulate in 22 Years. ISAAA Brief No. 53. ISAAA 2018, Ithaca, NY. See: http://www.isaaa.org/resources/publications/briefs/53/

81 Agenda 21, Section II Conservation \& Management of Resources for Development, Chapter 16 Environmentally Sound Management of Biotechnology.
} 
mentioned above, the broader public was suspicious of these products' safety. ${ }^{82}$ Risks were discussed controversially from the outset ${ }^{83}$, such as threatening biodiversity and health. There are main types of dangers/risks often mentioned as being more likely to occur. Priority one is the risk of health. Glyphosate, an herbicide that the GM crops can be immune to and is frequently referred to instantiate possible health risks, may release into the soil and activate the growth of fungus, Fusarium, and further cause botanical infections. Fusaria have a potentiality of toxin production, which have ultimately carcinogenic and cytotoxic effects ${ }^{84}$. Apart from the former instance, GM crops may tend to produce a certain amount of exogenous protein in excess ${ }^{85}$, and if it was an allergen undetectable by traditional methods, it might also cause allergies in certain people. The other concern is ecological danger/risk. Typical environmental damage possibilities include impacts on nontarget species ${ }^{86}$, unintended effects on biogeochemistry ${ }^{87}$, gene flow, the evolution of resistant pests or weeds threatening biodiversity ${ }^{88}$, etc. ${ }^{89}$ Of course, some other unknown

\footnotetext{
${ }^{82}$ Dadgarnejad, Kouser \& Moslemi, Genetically Modified Foods: Promises, Challenges and Safety Assessments, Applied Food Biotechnology Vol. 4:4 (2017), p.193.

${ }^{83}$ Karthaus, Risikomanagement durch ordnungsrechtliche Steuerung, 2001, p. 24.

${ }^{84}$ Fernandez et al, Glyphosate associations with cereal diseases caused by Fusarium spp. in the Canadian prairies, European Journal of Agronomy Vol. 31: 3, (2009), p. 133. Indeed, it has been proved that glyphosate affects soil's living organisms differently depending on dosage, number of applications and biochemical conditions of soil, and European Food Safety Authority (EFSA) believes that glyphosate does not cause carcinogenicity if used within the range of maximum residue limits. See: European Food Safety Authority. Conclusion on the peer review of the pesticide risk assessment of the active substance glyphosate, EFSA J. Vol. 13: 11 (2015), p. 1; Dadgarnejad, Kouser \& Moslemi, Genetically Modified Foods: Promises, Challenges and Safety Assessments, Applied Food Biotechnology Vol. 4:4 (2017), p.193.

${ }^{85} \mathrm{Fu} \& \mathrm{Liu}$, Exogenous Cry1 Ab/c Protein Recruits Different Endogenous Proteins for Its Function in Plant Growth and Development, Front Bioeng Biotechnol Vol. 8 (2020), p. 685.

${ }^{86}$ Rissler \& Mellon, The Ecological Risks of Engineered Crops, 1996, p.42.

${ }^{87}$ Unintended effects on the dynamics of populations in the receiving environment as a result of impacts on non-target species, may occur directly by predation or competition, or indirectly by changes in land use or farming practices. Unintended effects on biogeochemistry are through impacts on soil microbial populations that regulate the flow of nitrogen, phosphorus and other essential elements. The gene flow is transferring of inserted genetic material to other domesticated or native populations, through pollination, mixed matings, dispersal or microbial transfer. See: Ajami, Alimoradi \& Ardekani, Biotechnology: Two decades of experimentation with genetically modified foods, Applied Food Biotechnology, Vol. 3:4 (2016), p. 228 ; Dadgarnejad, Kouser \& Moslemi, Genetically Modified Foods: Promises, Challenges and Safety Assessments, Applied Food Biotechnology Vol. 4:4 (2017), p.193.; Dale, Clarke, and Fontes, Potential for the Environmental Impact of Transgenic Crops, Nature Biotechnology Vol. 20 (2002), p.571.

88 There are currently 500 unique cases (species x site of action) of herbicide resistant weeds globally, with 256 species (149 dicots and 107 monocots). Weeds have evolved resistance to 23 of the 26 known herbicide sites of action and to 167 different herbicides. Herbicide resistant weeds have been reported in 93 crops in 70 countries. For more information about the status of resistant weed. See: http://www.weedscience.org/

${ }^{99}$ Baram \& Bourrier (eds), Governing risk in GM agriculture, 2010, p. 7; Ajami, Alimoradi \& Ardekani, Biotechnology: Two decades of experimentation with genetically modified foods, Applied Food Biotechnology, Vol. 3:4 (2016), p. 228; Dadgarnejad, Kouser \& Moslemi, Genetically Modified Foods: Promises, Challenges and Safety Assessments, Applied Food Biotechnology Vol. 4:4 (2017), p.193.
} 
risks might exist. According to an Article published in nature, the presently most prominent GM technique, CRISPR/Cas, can cause accidental genetic deletions and complex genomic rearrangements exceeding experts' estimates..$^{90}$ Nevertheless, there has not been definite scientific evidence or sufficient empirical research supporting the potentially adverse effects of extensive cultivation of agricultural GMOs on biodiversity.

\subsubsection{Dilemma of Decision-making on ex-ante Intervention in GM Risk}

It is undoubtedly true that GM technology is relatively crucial to both China and Germany/the EU. On the one hand, most GM crops, like soybeans, neither in China nor in the EU, are legal. On the other hand, as China and the EU cannot cultivate self- sufficiently conventionally non-GM crops due to the finite area of arable land, they both have to import a large number of crops to avoid a deficit of supply, especially for feed use. ${ }^{91}$ That is to say, China and the EU have no choice but to rely on GMOs to fill the domestic gap in agricultural production. In the EU, GM soybeans, maize, and oilseed rape, cotton are imported to satisfy the substantive demand and used as feed material to farm animals, etc. Taking the soybean as an example, the total domestic yield, the most important protein source, is 1.7 million tons, accounting for less than $5 \%$ of EU need. ${ }^{92}$ As for China, more than 90 million tons of soybeans are consumed every year, and approximately $90 \%$ of soybeans are imported from the international market. There are two primary uses: oil extraction from soybeans for food use, and the other is producing feeding material with the residues from soybean oil extraction, i.e., feeding the pigs with soybean meal. ${ }^{93}$ Due to the impact of the trade war between the USA and China, China's imports of soybeans from Brazil increased from 50.93 million tons in 2017 to 66.082 million tons in 2018, accounting for $75.1 \%$ of China's imports. Meanwhile, the United States dropped from 32.86 million

\footnotetext{
${ }^{90}$ MKosicki, Tomberg \& Bradley, Repair of double-strand breaks induced by CRISPR-Cas9 leads to large deletions and complex rearrangements, Nature Biotechnology Vol. 36 (2018), p.765.

${ }^{91}$ Giovanni Tagliabue, The EU legislation on "GMOs" between nonsense and protectionism: An ongoing Schumpeterian chain of public choices, GM Crops Food Vol. 8:1 (2017), p. 57.

92 https://www.europabio.org/agricultural-biotech/faq/gmos-and-the-european-union/why-does-eu-importgmos

93 Using "soybean logic" to look at the US-China trade war

See: http://www.xinhuanet.com/world/2019-02/24/c 1124155745.htm
} 
tons in $2017^{94}$ to 16.64 million tons in 2018 , still accounting for $18.9 \%$ of China's imports. ${ }^{95}$ In fact, the amount of soybeans that South America can supply to China is about 70 million tons, while China's import demand is about 97 million tons, leaving a supply gap of several tens of millions of tons. It can be seen that even though reducing the demand for US soybeans, it is not yet possible to eventually find an alternative country to make up the demand gap in China.

Although GM technology is relatively crucial to both China's ${ }^{96}$ and the EU's social development, against the backdrop of shared public anxiety over GM techniques in China and the EU, the GM staple crop commercialization and especially the GM crop cultivation, both face the dilemma of social mis-confidence on both the safety of GM products and the sense of responsibility by the competent authorities. ${ }^{97}$ This predicament is distinctly reflected in that the decision-making on the authorization of GMOs has become politicized..$^{98}$ In the EU, since the entry into force of the current GMO legal framework Member States have rarely managed to find agreement in the relevant comitology committee (especially the Standing Committee on the Food Chain and Animal Health), thereby effectively precluding national input into the authorization process. ${ }^{99}$ Likewise, the same dilemma also exists in China. For example, although it has been authorized by granting the biosafety certificate, genetically modified rice cannot be marketed due to the

\footnotetext{
94 Why are soybeans getting the most attention in the US-China "trade war"? http://www.sohu.com/a/227298175 115362

${ }^{95}$ Using "soybean logic" to look at the US-China trade war http://www.xinhuanet.com/world/2019-02/24/c 1124155745.htm

${ }^{96}$ Chinese Twelfth Five-Year (2011-2015) biotechnology development plan, which is enact by Ministry of Science and Technology. The plan predicted that: In the new century, there are four major trends in territory of biotechnology entering on the international stage. Firstly, biotechnology has become a strategic focus of scientific research and capital investment in many countries. Secondly, one of the significant international scientific and technological competitions is definitely biotechnology. Thirdly, biotechnology stand a good chance to be new lever of economic growth. Fourthly, Biosafety has become an important part of ensuring national food and environmental security.

${ }^{97}$ Although the European Union has approved a GM soybean (MON 87708 x MON 89788 x A5547 - 127), the pace is still very slow compared to the development of technology.

${ }^{98} \mathrm{Du}$, et al. Development, challenges and countermeasures for industrialization of genetically modified staple crops in China, Current Biotechnology Vol. 6: 3 (2016), p. 159; Dai, Miao \& Ji, Key problems and countermeasures of the safety supervision of genetically modified crops in China, Agricultural economy Vol. 5 (2016), p. 51; Tan, Development path and strategy of commercialization of genetically modified crops in China, Agricultural Technology \& Economy Vol. 1 (2014), p. 22.

99 Weimer, No More Blame Game: Back to the Future of Comitology, 2017,

See: https://verfassungsblog.de/no-more-blame-game-back-to-the-future-of-comitology/
} 
public's aversion to genetic engineering. Therefore, the decision on GMOs has been completely politicized, and the legal system operates dysfunctionally. Indeed, GM feed for the production of meat seems to be considered acceptable by consumers.

\subsection{Research Problem and Structure of Research}

While the prosperity of modern industrial nations depends more than ever on the development of new technologies, ${ }^{100}$ technology becomes the acute problem of the law, its institutions, public authorities, politicians, and their representatives, who continuously see themselves partly compelled to directly and partly indirectly take intervention and control measures ${ }^{101}$, establish rules and resolve conflicts. This problem is growing with the spread of uncertainty. ${ }^{102}$ While sufficient information will not be present in due time, indefinitely postponing decisions on permitting the GMO application would violate the economic actors' freedom, but hasty permission of new technology may also infringe on citizens' and neighbors' security rights in the future. ${ }^{103}$ Consequently, even though there is often insufficient and/or not specific information, a decision must be taken anyhow under political and legal pressure. However, traditional law and even the present risk law on decision-making are often seen as both inefficient and unequipped to govern technological change, evolving rapidly, particularly in the ex-ante prevention domain.

The administrative decision-making system for ex-ante intervention in the risks presented by GMOs in the form of an authorization should have played a role in fully balancing the freedom of technological development with the safety needs of the public, just like the traditional danger prevention system, but the decision was simply difficult to reach so that

\footnotetext{
${ }^{100}$ Assmann, Neue Technologien als Herausforderung, in: Asada (ed), Das Recht vor den Herausforderungen neuer Technologien, 2006, p. 5.

${ }^{101}$ Assmann, Neue Technologien als Herausforderung, in: Asada (ed), Das Recht vor den Herausforderungen neuer Technologien, 2006, p. 5.

102 Pardo, Entscheiden und Regulieren in der Ungewissheit. Antworten und Strategien des öffentlichen Rechts, in: Darnaculleta i Gardella, Pardo, \& Spiecker gen. Döhmann (eds), Strategien des Rechts im Angesicht von Ungewissheit und Globalisierung, 2015, p. 23.

${ }^{103}$ Spiecker genannt Döhmann, Uncertainty in EU Technology Regulation: How law making and law enforcing matters, in: Weimer, Cseres \& Eckes (eds.), The Rule of Law in the Technological Age: Challenges and Opportunities for the EU: collected papers ACELG 6th Annual Conference, 2017, p. 38.
} 
the commercial use of the technology was not guaranteed. Perhaps the main reason for this problem is the psychological reason for the public's reluctance to accept uncertainty. Despite that, for Germany/the EU and China, it is still questionable, after several decades of practical and theoretical reorientation, whether there is a possibility that this impasse could be resolved by changing the administrative risk decision-making mechanism? If so, which aspect of the legal regime remains to be improved to solve the current decisionmaking dilemma regarding GMOs? Before these questions can be answered, two more questions need to be listed together: What exactly has contributed to reformulating the legal system until now? How has GMO regulation on administrative risk decision-making addressed the issue of uncertain risk and reconstructed the balance between freedom and security? These are questions that deserve to be studied by legal scholars. In addition, such research would be beneficial to provide experience and lessons for the subsequent regulation of technology with uncertain risks, such as synthetic biology.

This dissertation reviews the administrative risk decision-making mechanism regarding GMOs in Germany/the EU and China and investigates whether there is a possibility of reformulating it to resolve the GMO authorization impasse. There are two reasons for choosing this topic. Firstly, both China and Germany/the EU are facing difficulties in decision-making on GMOs, so it is good to compare them with each other to determine whether there is a possibility of improving the law. Countries indeed take different measures in dealing with GMOs' issues depending on their national conditions and cultures. However, the GMO issue is ultimately a scientific and technological risk issue. The core of it is the balance between "scientific and technological freedom and social security," and there is undoubtedly much homogeneity in measures taken by countries. The homogeneity of problems and measures is the basis of comparative law research. Therefore, the comparison between Germany/the EU and China is meaningful, at least for China. Compared to Germany, the theoretical discussion on the regulation of risk in China is inadequate. The trend of legal scholars in mainland China focusing on uncertain risk originated when Baker's "Risk Society" was translated into Chinese in 2004. However, unlike Germany, which has constructed a comprehensive doctrinal system of danger 
prevention, China lacks a systematic theory of ex-ante preventive measures in the field of administrative law. Therefore, Chinese risk research, especially on the issue of the challenge of risk to the traditional legal system, lacks a frame of reference and is mixed with the conventional issue of administrative legality. Secondly, administrative risk decision-making in the field of GM techniques in connection with agriculture and food, raises concerns and is a controversial area today; therefore, the dissertation narrows the research area to green GMOs. Nowadays, the use of genetic engineering methods in diagnostics as well as in the research, development, and production of drugs and other industrial products, i.e., the area of so-called white gene technology, has met with relatively broad acceptance, only the conflicts over the use of the so-called green genetic engineering are further tightened with the development and approval of genetically modified plants for the commercial cultivation of food and feed.

The dissertation will analyze four concrete questions: Firstly, how does the conventional administrative decision-making mechanism regarding danger prevention operate? Secondly, what challenges do the GMOs pose to the conventional decision-making mechanism? Thirdly, how does the general legal theory respond to uncertain risk? Fourthly, how is the general risk management theory regarding the administrative risk decisionmaking mechanism is concretely implemented by GMOs regulation in Germany/the EU and China?

Specifically, at the beginning of analyzing these legal questions, defining the critical concepts such as risk, danger, damage, and the administrative decision-making mechanism and clarifying the characteristic features of modern risk in the chapter 2 is necessary. Usually, risk and danger are both a kind of situation with the likelihood to cause real damage (negative result); nevertheless, they are distinguished from each other in parameters (occurrence possibility, damage extent, and certainty) (see section 2.1.1). Besides, the administrative risk decision-making mechanism is defined according to social science in the broad sense in the first chapter. Briefly speaking, it refers to an institutionalized behavior-oriented operating system that an administrative authority 
chooses as the instrument/act to fulfill its tasks under a given the regulatory framework. The legal decision-making system encompasses three constitutive elements: the decisionmaking aim of value, the operating principles, and specified specific contents of decisionmaking (including the substantive decision-making standard, participating subjects, and procedure. (see section 3.2) In addition, the characterized features of modern risk are summarized in the following way: the manifestation of risk shows epistemic uncertainty; the influence of risk is no more individual but collective and wide-ranging; human beings manufacture the generation of risk because of the deficits of knowledge; the assessment still largely depends on high-technology; as the regulating system aims to ensure social acceptability of risk under uncertainty, the valuation of risk is value-concerned.

An overview of conventional legal decision-making dealing with danger is given following the terminology section in chapter 3 . The classic ex-ante coping with a challenge of possible harm is danger prevention, i.e., under the circumstances of doctrinal danger (sufficient probability of occurrence of damage or the appearance of a "disturbance" as an already realized probability of loss), the competent authority could take the legitimate measures to intervene in the situation avoiding the realization or aggravation of damage. Subsequently, the ex-ante danger prevention serves as a benchmark for the following findings on which parameters will be challenged by modern risk, i.e., the challenges presented by modern risk to the classic mechanism would be interpreted. (Chapter 4 ). In the chapter 5 , the legal response to modern risk in the domain of administrative decision-making is worked out. The chapter 6 analysis the status quo of risk decision-making within the framework of GMO regulation in Germany/the EU and China. 
When the uncertain technological risk seriously affects people's social life and sense of security, the state's security obligations are activated. As an important measure for the state to guarantee security, the law must also serve this purpose. Just as Maria Weimer presents: "Law is not merely an obstacle to technology, but as an institution crucial to managing the tension inherent in emerging technologies, between risk and innovation, anxiety and promise". ${ }^{1}$ The legislation and implementation of laws must be based on a relatively objective examination of social interrelationships and a balance of interests. Therefore, when reviewing the issue of uncertain risk and investigating whether there is a possibility of reformulating the administrative risk decision-making mechanism to resolve the GMO authorization impasse, the first step would be better to go back to the starting point, i.e., observe the characteristics of uncertain risk and provide an objective basis for adjusting the law. This chapter will identify several essential terminologies for the research (section 2.1) and summarize the characteristic features of the uncertain risk of GMOs (section 2.2).

\subsection{Terminology}

\subsubsection{Danger, Risk, Hazard, and Uncertain Risk}

Even though the general meaning of risk can be understood associatively or approximately for daily life, there is still a lack of consensus on doctrinal identification or conceptualization due to the confusion among several synonymic terms. The problem of identifying the "risk" lies not in the absence of definitions, as they are numerous in the literature, but their inadequacy. Some succeed better than others, but none is sufficient to prevail over others. ${ }^{2}$ Even though the risk is a portmanteau word, exploring the identification of risk is no longer attracting the researchers' primary attention; in contrast,

\footnotetext{
${ }^{1}$ Weimer \& Marin, The Role of Law in Managing the Tension between Risk and Innovation: Introduction to the Special Issue on Regulating New and Emerging Technologies, European Journal of Risk Regulation Vol.7: 03 (2016), p. 469.

${ }^{2}$ Silveira Marques, Der Rechtsstaat der Risikovorsorge, 2018, p. 53-55.
} 
in addition to the study of risk-regulating strategies, such as knowledge generation, proceduralization, and risk allocation, etc., it is still one of the important topics of risk regulating theory research. Since that conceptual precision facilitates communication, the effort to find the appropriate terms should not be given up hastily, even if the colloquial language seems to guarantee sufficient comprehensibility. ${ }^{3}$ The following part will examinate the concept of "risk." Meanwhile, several confusing partly synonymous concepts such as risk, danger, hazard, and uncertain risk, will be compared respectively under the EU, German, and Chinese legal context, where semantic nuances exist in the relevant jurisprudential literature.

\subsubsection{In Germany}

To understand the legal term 'risk,' it is necessary to understand the legal term 'danger.' Risk (Risiko) and danger (Gefahr) in Germany both mean a possible or probable occurrence of damage to a legitimate interest. Unlike danger, which can be considered as the Archimedean point of German administrative law, ${ }^{4}$ risk was not a legal concept from the outset. Thus, traditional administrative law's ex-ante preventive measures are focused solely on dangers.

In the doctrinal theory of German law, the unique term "danger" refers to a situation that, if the events continue unhindered, leads to damage to the protected legal interests with sufficient probability. ${ }^{5}$ The protected legal interests in administrative law are usually "public security" (or "public order") or qualified rights. ${ }^{6}$ Furthermore, in addition to the requirement that the situation would cause disturbance to the legitimate interest, the

\footnotetext{
${ }^{3}$ Murswiek, Die staatliche Verantwortung für die Risiken der Technik, 1985, p. 72.

${ }^{4}$ Huber, Risk decisions in German constitutional and administrative law, in: Woodman \& Klippel (eds), Risk and the Law, Routledge, 2009, p. 21.

${ }^{5}$ Götz \& Geis, Allgemeines Polizei- und Ordnungsrecht, 2017, p. 561; Rehbinder, Immissionsschutzrechtlicher Gefahrenbegriff, BB (1977), p. 1. Murswiek, Die staatliche Verantwortung für die Risiken der Technik, 1985, p. 83.

${ }^{6}$ Federal Administrative Court, BVerwGE 45, 51 (57); 116, 347 (351); Thiel, Die "Entgrenzung" der Gefahrenabwehr, 2011, p. 51.
} 
situation must also meet the requirement of sufficient likelihood of occurrence to be identified as "danger". The danger plays a role in justifying the corresponding state's exante intervention in individual rights to prevent loss or avoid deterioration since the Prussian era. (more information in Chapter 3) In other words, danger represents disturbances to be removed by law and the boundary of legal security, i.e., the scope of legal regulation. Suppose the circumstances that may damage legitimate interests are out of the range of danger situation, i.e., do not meet the identifying requirements of danger. In that case, they will not be regulated by the legal regime and classified into residual risks. The residual risk goes beyond the boundary of legal security and is considered socially acceptable. In German legal theory, risk (Risiko) or uncertain risk has not been a doctrinal legal concept from the outset, ${ }^{7}$ which was handled practically as "residual risk". However, it has found its way into the legal discussion of recent years ${ }^{8}$, which called for extending the scope of legal regulation from danger to risk for the sake of social security.

In addition, based on the discernible character of danger, depending on how and by whom the danger originates, or on the means by which the competent authorities prevent it ${ }^{9}$, the following categories of danger were generally recognized, which are undoubtedly not exhaustive: concrete danger and abstract danger ${ }^{10}$; objective danger and subjective danger ${ }^{11}$;

\footnotetext{
${ }^{7}$ For more information see: Murswiek, Die staatliche Verantwortung für die Risiken der Technik, 1985; Di Fabio, Risikoentscheidungen im Rechtsstaat, 1994; Jaeckel, Gefahrenabwehrrecht und Risikodogmatik, 2010; Ipsen \& Murswiek Die Bewältigung der wissenschaftlichen und technischen Entwicklungen durch das Verwaltungsrecht, VVDStRL Vol. 48 (1990), p. 177; Scherzberg \& Lepsius, Risikosteuerung durch Verwaltungsrecht: Ermöglichung oder Begrenzung von Innovationen?, VVDStRL Vol. 63 (2004), p. 214;; Byungwoog, Wandel des klassischen Polizeirechts zum neuen Sicherhei, 2013; Delhey, Staatliche Risikoentscheidungen, 2014; Silveira Marques, Der Rechtsstaat der Risikovorsorge, 2018; Dreyer, Entscheidungen unter Ungewissheit im Jugendmedienschutz, 2018; Calliess, Rechtsstaat und Umweltstaat, 2001; Eifert \& Hoffmann-Riem, Innovationsverantwortung: Innovation und Recht III, 2009; Hiller, Der Zeitkonflikt in der Risikogesellschaft, 1993; Kloepfer (ed.), Technikumsteuerung als Rechtsproblem, 2002; Ladeur, Das Umweltrecht der Wissensgesellschaft, 1995; Ladeur, Gefahrenabwehr und Risikovorsorge bei der Freisetzung von gentechnisch veränderten Organismen nach dem Gentechnikgesetz, NuR Vol. 6 (1992), p. 254; Thiel, Die "Entgrenzung" der Gefahrenabwehr, 2011; Poscher, Gefahrenabwehr: Eine dogmatische Rekonstruktion, 1999; Scherzberg, Risiko als Rechtsproblem, VerwArch. Vol 84 (1993), p484.; Wahl \& Appel (eds.), Prävention und Vorsorge, 1995; Wollenschläger, Wissensgenerierung im Verfahren, 2009.

${ }^{8}$ BVerfGE 49, 89 (139)

${ }^{9}$ Byungwoog, Wandel des klassischen Polizeirechts zum neuen Sicherhei, 2013, p. 182.

${ }^{10}$ Byungwoog, Wandel des klassischen Polizeirechts zum neuen Sicherhei, 2013, p. 183 et seq.; Thiel, Die "Entgrenzung" der Gefahrenabwehr, 2011, p. 51 et seq.

${ }^{11}$ Jaeckel, Gefahrenabwehrrecht und Risikodogmatik, 2010, p. 91 et seq. Poscher, Gefahrenabwehr: Eine dogmatische Rekonstruktion, 1999, p. 83.
} 
apparent and suspected danger ${ }^{12}$. The typification of dangers in the form of "concrete and abstract" corresponds to different allocations of tasks between legislature and administration ${ }^{13}$ and of preventive measures. ${ }^{14}$ The dissertation will go into detail relating to the "concrete/abstract" dichotomy because it, too, can be applied to the classification of risks and thus influence the subsequent choice of precautionary measures (see Chapter 4).

Roughly speaking, concrete danger refers to a specific situation in which “... a situation or behavior in the unhindered course of events objectively is to be expected likely to damage a legal asset," which is mainly under the control of police law. In general, an action is not necessarily dangerous, but in combination with specific conditions (subjective and objective ones), it may be a threat to legitimate goods; thus, the concrete danger refers to the state of combining an action with specific conditions in a temporal perspective. As for the abstract danger, it is primarily conceived as a summary of a category of situations or behaviors that typically cause damage, which may lead to damage irrespective of a specific point in time and the circumstances of the individual case ${ }^{15}$, unlike the concrete danger with its spatial and temporal peculiarity. Certain events are of "statistical relevance" (are "cause") to certain damages. Suppose we can make a statement about such statistical relevance of an event class utilizing statistical investigations. In that case, we are entitled to speak of an "abstract danger" that may be caused by those events. ${ }^{16}$ Due to its relative independence and relatively low correlation with the environment, in order to reduce, rather than altogether avoid, the damages, a normative measure can be formulated in legislation to entitle the administrative organs to judge the specific situation and to take reactive intervention measures, such as ex-ante permission. Of course, this does not mean that there is any difference between them by the degree of probability of the damage occurring, which

\footnotetext{
${ }^{12}$ Byungwoog, Wandel des klassischen Polizeirechts zum neuen Sicherhei, 2013, p. 183 et seq.

${ }^{13}$ Gusy, Polizei- und Ordnungsrecht (10th edition), 2017, p. 102 et seq.; In general, while a concrete danger can justify the taking of defensive measures by the executive organization, the "abstract danger" was basically conceived as a prerequisite for the enactment of legal regulations to improve the normativity of the exercise of state power.

${ }^{14}$ In addition, a doctrinal distinction has traditionally been made between abstract and concrete danger, see: Darnstädt, Gefahrenabwehr und Gefahrenvorsorge, 1983, p. 22; Jähnke, Fließende Grenzen zwischen abstrakter und konkreter Gefahr im Verkehrsstrafrecht, DRiZ 1990, p. 425.

${ }^{15}$ Darnstädt, Gefahrenabwehr und Gefahrenvorsorge, 1983, p. 57.

${ }^{16}$ Darnstädt, Gefahrenabwehr und Gefahrenvorsorge, 1983, p. 3.
} 
criterion applies to the concrete danger as well as the abstract one, ${ }^{17}$ but means the difference existing in the reference point of the danger prognosis and or in the approach (perspective) ${ }^{18}$

As a result, while a concrete danger can justify the taking of defensive measures by the executive organization, ${ }^{19}$ the "abstract danger" was basically conceived as a prerequisite for enacting legal regulations to improve the normativity of the exercise of state power. The abstract danger can also be regulated as a concrete danger, which requires that an abstract factual situation exists that, according to general life experience and the knowledge of competent authorities, makes it appear possible to develop into a (future) concrete danger situation ${ }^{20}$. In the case of normative statements about concrete dangers, the lawmaker is responsible for authorizing the administration to intervene in the danger situation. The administration shall substantiate the assumption of causality between a certain behavior and possible damage, interdict inducing damage, and ensure the integrity of legitimate interests. In the case of normative statements about abstract dangers, the lawmaker is deemed to formulate a general assumption of the cause-and-effect relationship of certain behavior and the occurrence of damage, prohibit performance of this behavior in a normative way, or empower the administration to substantiate the expectation of a damaging event and ensure that the legal norms are observed. ${ }^{21}$

Unlike danger, risk has gradually entered into the legal discussion and become a legal concept. According to whether a "concrete" precautionary reason can be justified by scientific knowledge, jurisprudence distinguishes between the area of risk, which may be the subject of possible precautionary measures, and the "residual risk," which cannot be (economically) dealt with. However, risk (Risko) in Germany has so far normally been

\footnotetext{
17 Federal Administrative Court, BVerwGE 45, 51, 57; 116, 347, 351.

${ }_{18}$ Götz, Allgemeines Polizei- und Ordnungsrecht (14th edition), 2008, p. 38; Pieroth,et al, Polizei- und Ordnungsrecht (6th edition), 2010, p. 25; Byungwoog, Wandel des klassischen Polizeirechts zum neuen Sicherhei, 2013, p. 189.

${ }^{19}$ Byungwoog, Wandel des klassischen Polizeirechts zum neuen Sicherhei, 2013, p. 190; Schenke, Polizei- und Ordnungsrecht, 2009, p, 37; Möstl, Gefahr und Kompetenz - Kampfhundeentscheidung, Jura 2005, p. 52.

${ }^{20}$ Pieroth,et al, Polizei- und Ordnungsrecht (6th edition), 2010, p. 60.

${ }^{21}$ Darnstädt, Gefahrenabwehr und Gefahrenvorsorge, 1983, p. 2, 28.
} 
defined in demarcation from the doctrinally established legal concept of "danger," as possible damage below the threshold of danger. ${ }^{22}$ It includes situations where the degree of damage and the probability of occurrence are uncertain, as well as situations where the probability of occurrence is low, and the likelihood of occurrence is not imminent, etc. Therefore, in the German jurisprudential research on risk theory, there are two juxtaposing concepts. In Germany, the binary concepts of risk (Risko) and danger (Gefahr) both constitute what is understood under the unitary British concept as "risk". The word danger (Gefahr) in German terminology is equal to imminent and highly probable risk in the British context. ${ }^{23}$ Accordingly, risk (Risiko) in German terminology is similar to potential risk in the British understanding.

Although risk is gradually becoming a separate legal concept, there is no consensus and convincing theory on the demarcation between risk and danger in Germany. The delimitation of danger, risk, and residual risk is not easy to draw and, to a certain extent, also flexible insofar as in addition to the relevant degree of probability of harm, the magnitude, and severity of potential harm, the value attributed to the affected interest by the Constitution and some other factors must be considered. ${ }^{24}$ In particular, uncertain risk (Risiko) is complicated to describe or conceptualize. However, there is always a definitional comparison between risk (Risiko) and danger because their point of similarity is the possibility of damage. The German theory has two mainstream methods of classification: the three-tier risk model (danger-risk- residual risk) and the two-tier risk model (riskresidual risk).

The so-called three-tier risk model encompasses three typifications according to the probability of damage occurring: danger, risk, and residual risk, originating in environmental law and technical safety law. ${ }^{25}$ According to general or specific empirical

\footnotetext{
${ }^{22}$ Delhey, Staatliche Risikoentscheidungen, 2014, p. 27.

${ }^{23}$ Werner Heun, Staatliche Risikosteuerung und Verfassung, RW Vol. 2 (2011), p. 377.

${ }^{24}$ Rehbinder, Low Doses in Health-Related Environmental Law, in: Streffer et al. (eds), Low Dose Exposures in the Environment, 2004, p. 328.

${ }^{25}$ Delhey, Staatliche Risikoentscheidungen, 2014, p. 38.
} 
values, a danger refers to the occurrence of a damaging event that is imminent with sufficient probability. Risk (in the narrow sense) refers to the loss that is associated to the known (calculable) possibility of occurrence and uncertain possibility, which is "below the danger threshold" but cannot be classified as residual risk. The uncertain risk refers to the damage that cannot be predicted with sufficient probability, in which the empirical knowledge is not available at all or not sufficient, i.e., the further development of the course, the occurrence, or its consequences is uncertain. The precautionary rule addresses risk below the limit of danger. ${ }^{26}$ The occurrence of damage that cannot be ruled out in principle is classified as residual risk. ${ }^{27}$

In contrast, a two-tier risk concept differentiates regulated risk from residual risk, exemplified by nuclear law. ${ }^{28}$ All probable damaging events that have legal relevance are collectively referred to as risks (in the broad sense), and dangers are a subset of risks; probable damage that does not have legal relevance and should be accepted by society as a common burden is classified as residual risk. The Law on Genetic Technology (Gentechnikgesetz - GenTG) does not explicitly commit itself to a specific risk concept. However, the wording, structure, and regulatory purpose of the law speak in favor of the two-stage risk concept. Precautionary measures are required in the area of all risks. ${ }^{29}$ Furthermore, the doctrinal evolution of risk is progressive, and there are various typical scholarly definitions in the academic discourse..$^{30}$

\footnotetext{
${ }^{26}$ Rehbinder, Low Doses in Health-Related Environmental Law, in: Streffer et al. (eds.), Low Dose Exposures in the Environment, 2004, p. 326-327.

${ }^{27}$ Di Fabio, Risikoentscheidungen im Rechtsstaat, 1994, p. 105; Delhey, Staatliche Risikoentscheidungen, 2014, p. 38.

${ }^{28}$ Jaeckel, Gefahrenabwehrrecht und Risikodogmatik, 2010, p. 64 et seq.

${ }^{29}$ Lepsius, Risikosteuerung durch Verwaltungsrecht: Ermöglichung oder Begrenzung von Innovationen?, VVDStRL Vol. 63 (2004), p. 266.

${ }^{30}$ For example, Murswiek, Die staatliche Verantwortung für die Risiken der Technik, 1985; Di Fabio, Risikoentscheidungen im Rechtsstaat, 1994; Scherzberg, Risiko als Rechtsproblem, VerwArch. Vol 84 (1993), p. 484; Lepsius, Risikosteuerung durch Verwaltungsrecht: Ermöglichung oder Begrenzung von Innovationen?, VVDStRL Vol. 63 (2004), p. 214.; Jaeckel, Gefahrenabwehrrecht und Risikodogmatik, 2010; Delhey, Staatliche Risikoentscheidungen, 2014.
} 


\subsubsection{In the EU}

Risk, hazard, residual risk, and uncertain risk are commonly utilized in the terminology of EU law and academic research. The terminology of EU law on risk is similar to the German two-tier risk model. The uniform concept of risk in European Union legislation refers to all legally relevant possible damage, such as Regulation (EC) No 178/2002 (Food Law). There is no further division according to risk based on the degree of likelihood of damage occurring. In general, from a legal discipline perspective, possible damage that is not legally relevant is identified as residual risks. There is no unique concept of "danger" in AngloSaxon "risk" terms to express the high probability of damage ${ }^{31}$, which is fundamental to German security doctrine. ${ }^{32}$ Besides, the EU legislation makes a clear distinction between risk, i.e., the possibility of causing damage, and hazard ${ }^{33}$, i.e., property or attribute of an activity or substance with the potential of entailing damage. Although the distinction between prevention and precaution is laid down in Art 191 (2) TFEU, EU regulation is based on a relatively simple risk concept, which encompasses both danger prevention and risk precaution in the German law context and need only be distinguished from the legally irrelevant "residual risk". ${ }^{44}$ The uncertain risks, such as GMO risks and synthetic biology risks, which are now of general concern, are also discussed under the concept of risk; hence, there is no theory to distinguish them. ${ }^{35}$

In the EU legislation, a basic identification of risk and hazard is provided in Article 3(9) and (14) of Regulation (EC) No 178/2002 on food and feed, which provides that:

'risk' means a function of the probability of an adverse health effect and the severity of that effect, consequential to a hazard;

'hazard' means a biological, chemical, or physical agent in, or condition of, food or feed

\footnotetext{
${ }^{31}$ Danger is a concept generally used in Germany legislation, which describes the high possibility of undesired consequences.

${ }^{32}$ Appel \& Mielke, Strategien der Risikoregulierung, 2014, p. 17.

33 Once there was fierce debate about the distinction between risk and hazard, and corresponding approaches. See, Lofstedt, Risk versus Hazard: How to Regulate in the 21st Century, European Journal of Risk Regulation Vol. 2 (2011), p. 149.

${ }^{34}$ Rehbinder, Stoffrecht, in: Rehbinder \& Schink (eds.), Grundzüge des Umweltrechts (5th edition), 2018, p. 1225.

35 Paciotti, Law, Uncertainty and Emerging Technologies, Personay Derecho Vol. 62 (2010), p. 15.
} 
with the potential to cause an adverse health effect;

There is no explicit legal definition of the concept of risk in genetic engineering law, but Annex II C of Directive 2001/18 does contain elements of such a definition. According to point C. 2. no 4, the risk assessment shall take into account the potential to cause adverse effects by "combining the likelihood of the adverse effect occurring and the magnitude of the consequences if it occurs." 36

That is to say, "hazard" and "risk" are entirely different concepts. The term "hazard" is utilized to describe the inherent properties of an activity or a substance to cause an adverse effect when an organism, system, or (sub) population is exposed to that substance or situation. ${ }^{37}$ This ability may even never materialize if, for example, the target's subjects or objects are not exposed to the hazards or made resilient against the hazardous effect. ${ }^{38}$ "Risk," by contrast, means the likelihood of an adverse impact on an organism, system, or a (sub) population caused by exposure to a substance or activity under specific conditions. ${ }^{39}$ The decisive identifying factor for risk is weighing the possible scale of damage with the probability of exposure and the related harm. ${ }^{40}$ In addition to the imminent hazard presented, the substance's biological effectiveness (distribution or mobility) and the type, intensity, and extent of exposure of humans and the environment are essential standards to assess the risk. ${ }^{41}$ In brief, the concept of risk is characterized as effect-related based on distribution and exposure, while hazard is inherent harmful property-related.

With the development of technology, uncertain risk has generated much discussion in EU academic literature (not all of which juridical one) that combines uncertainty and risk. ${ }^{42}$

\footnotetext{
${ }^{36}$ Klafki, Risiko und Recht, 2017, p. 11.

${ }^{37}$ Renn, Concepts of risk: A classification', in S. Krimsky and D. Golding (eds.), Social Theories of Risk, Praeger 1992, footnote 1

${ }^{38}$ Scheer, The Distinction Between Risk and Hazard, Risk Analysis Vol. 34 (2014), p. 1270.

${ }^{39}$ Ulbig, Hertel \& Böl (eds), Evaluation of Communication on the Differences between "Risk" and "Hazard", Federal Institute for Risk Assessment 2010, p. 6.

${ }^{40}$ Scheer, The Distinction Between Risk and Hazard, Risk Analysis Vol. 34 (2014), p. 1270.

${ }^{41}$ Rehbinder, Stoffrecht, in: Rehbinder \& Schink (eds.), Grundzüge des Umweltrechts (5th edition), 2018, p. 1225.

${ }^{42}$ van Asselt \& Vos, EU Risk Regulation and the Uncertainty Challenge, in: Roeser, S. et al (eds), Handbook of
} 
However, a clarification is made by scholars, which is that uncertainty cannot be equated with risk. Walker et al. ${ }^{43}$ define uncertainty as "Any deviation from the unachievable ideal of completely deterministic knowledge of the relevant system." ${ }^{44}$ Uncertainty arises due to a lack of information or disagreement over knowledge of a particular subject. ${ }^{45}$ The knowledge or experience also plays a decisive role in this identification. In comparison, uncertainty indicates that the occurrence of damage is incredibly uncertain, which means that the uncertain situation may inhibit no negative effect; the property of damage is sure to exist in a risk situation. Asselt and Vos define uncertain risks as "new, imaginable hazards, with which society has no or limited experience." 46 They differentiate the uncertain risk from the typical risk based on whether any damage cannot be calculated and quantified due to a deficit of sufficient daily or practical experience or not. Tosun defines uncertain risks as "situations in which the causal relationship between activities and their potential hazard cannot be established." ${ }^{77}$ Tosun's identification underlines that the causal link cannot be determined. Literally, the incapability of determining a causal connection is just a kind of manifestation of a deficit of empirical or scientific experience.

In a modern risk society, uncertain risk is an external appearance, and lack of knowledge is an internal cause of it. Not every uncertainty represents a risk, while uncertain risk can always be understood as a form of uncertainty. Essentially, if the risk, in general, is judged in a flat coordinate system with the probability of occurrence and the degree of damage as horizontal and vertical coordinates, uncertain risk is judged in a three-dimensional coordinate system with the probability of occurrence, the degree of damage, and uncertainty, as coordinates.

\footnotetext{
Risk Theory, 2012, p. 1119.

${ }^{43}$ Walker, et al, Defining Uncertainty: A Conceptual Basis for Uncertainty Management in Model-Based Decision Support, Integrated Assessment Vol. 4: 1 (2004), p. 5.

${ }^{44}$ Jansen et al, Breaking Down Uncertain Risks for Risk Communication, Risk, Hazards \& Crisis in Public Policy Vol 9: 1 (2018), p.4.

${ }^{45}$ Painter, Climate change in the Media, 2013, p. 11.

${ }^{46}$ van Asselt \& Ellen, Wrestling with Uncertain Risks: EU Regulation of GMOs and the Uncertainty Paradox, Journal of Risk Research Vol. 11 (2008), p. 281.

47 Tosun, How the EU Handles Uncertain Risks: Understanding the Role of the Precautionary Principle, Journal of European Public Policy Vol. 20: 10 (2013), p. 1517.
} 


\subsubsection{In China}

China's development of law substantially imitates Germany's rule of law, especially in criminal law. The concepts of danger and risk are juxtaposed in China legal texts. The danger was an absolutely more crucial concept in the legal regime in the early stage of modern development in China; for example, the type concept "Dangerous driving offences (crime) (a kind of abstract danger)" in criminal law and the joint danger (die gemeinsam verursachte Gefahr $)^{48}$ in civil law. According to statistics elaborated by scholars, there are 93 laws and regulations that employ the term "danger" (including regulations that have been annulled), and 53 that use the term "risk." ${ }^{49}$ The concept of danger in criminal law and civil law is relatively precisely defined; that is, danger is an activity that is highly probable to cause damage to a legitimate interest. However, in administrative law, risk and danger are often used in an indiscriminative way; there is no clear demarcation.

\subsubsection{The Administrative Decision-making Mechanism on Risk}

Concluding from social science in the broad sense, ${ }^{50}$ the administrative decision-making mechanism refers to an institutionalized behavior-oriented operating system that an administrative authority chooses as the instrument/act to fulfill its tasks under a given regulatory framework. Three elements constitute it: the decision-making aim of value, the operating principles, and specific contents of decision-making (including the substantive decision-making standard, participating subjects, and procedure). ${ }^{51}$ The administrative decision-making mechanism's constitutive elements can also be roughly divided into two categories according to the nature of their content: the substantive domain (including the aims of value, operating principles, and decision-making standards) and procedural domains (including the participating subjects and procedure).

\footnotetext{
${ }^{48} \mathrm{~A}$ joint danger refers to that danger is caused by more than one offender or infringer

${ }^{49}$ Zhao, The Administrative Law's Response to Risk Society: Focusing on Health and Environmental Risk Regulation, 2018, p. 90.

50 Becker, Entscheidungen in der öffentlichen Verwaltung, in: König \& Siedentopf (eds), Öffentliche Verwaltung in Deutschland, 1997, p. 435; Schuppert, Verwaltungswissenschaft, 2000, p. 740 et seq.

51 They do not strictly stand side by side in isolation.
} 
Viewed from the perspective of the administrative decision-making mechanism, every administrative intervention is an administrative decision. It is made within the administrative decision-making mechanism and ultimately presented in the form of an administrative act. According to the type of administrative act as the classification criteria, the administrative decision-making mechanism can be divided into mechanisms regarding ex-ante prevention, including danger prevention and risk precaution, and mechanisms regarding ex-post repression, e.g., punishment for violation.

The conventional administrative decision-making mechanism relating to ex-ante prevention is designed to produce the preventive measure against danger. The administrative risk decision-making mechanism is another subordinate category of an administrative mechanism regarding ex-ante prevention, which refers to the decision that the administrative authority has to choose the ex-ante measure of intervention based on predicting how the facts of the case at hand will develop. ${ }^{52}$ The common characteristic of risk decisions is, to a certain degree, cognitive uncertainty in assessing the probability of occurrence and extent of damage and the relaxation of the "cause-and-effect relationship". ${ }^{53}$ Risk decision-making is no longer a selective decision within a range of fluctuation of given facts determined by rational scientific information but a process of construction and modeling of possibilities; the process is from the outset designed for self-transcendence and inconceivable without a moment of participation. ${ }^{54}$

The administrative decision-making mechanism covers the whole process of producing an administrative decision, including activities within the administration and acts with an external impact, both normative and case-by-case forms of action, both legal acts and real acts. ${ }^{55}$ Legal rules play the role of governing the execution of administrative power,

\footnotetext{
52 Schoch, Nachprüfung von Ermessensentscheidungen, in: Schoch \& Schneider (eds.), Verwaltungsgerichtsordnung, § 114 , No. 151.

${ }^{53}$ Di Fabio, Risikoentscheidungen im Rechtsstaat, 1994, p.115 et seq.

${ }^{54}$ Ladeur, Risiko und Recht, in: Bechmann G. (ed) Risiko und Gesellschaft. 1993, p. 209.

${ }^{55}$ Di Fabio, Risikoentscheidungen im Rechtsstaat, 1994, p. 7.
} 
protecting the affected citizen's legitimate rights, guaranteeing state aims, etc. Accordingly, the legal regulatory system will selectively formulate specific rules regarding the decisionmaking components, i.e., the regulatory structures to control administrative decisionmaking normatively. ${ }^{56}$ Indeed, some activities related to decision-making are not regulated by law, such as the internal behavior of administrative bodies.

The aim of value of the administrative decision-making mechanism is regulated by the constitutional and legislative aim of the administrative activity. There are some legal principles to bind the operating principle of the administrative decision-making mechanism. The element of "the decision-making content" is relevant to the application of law (execution) in the manner of subsuming the individual facts under the constituent facts of the legal norm (Tatbestand) and, if necessary, determine the corresponding legal consequence (Rechtsfolge). ${ }^{57}$ The administrative margin of appreciation (Beurteilungsspielraum) and discretion (Ermessen) signify a certain administrative decision-making freedom. ${ }^{58}$, relating to the constituent facts of the legal norm (Tatbestand) and legal consequences (Rechtsfolge). A margin of appreciation, for instance, may be recognized with respect to an undefined concept or open structure of a statutory term. ${ }^{59}$ Normally, the decision is bounded. This means that the administration is under a duty to make decisions that are the product of the relevant facts as determined and the application of law to these facts and to -provide for the legal consequences as mandated by the applicable law. However, the authority may also possess a certain degree of leeway in the shape of a margin of appreciation regarding the interpretation and application of law and of discretion regarding the legal consequences.

\footnotetext{
${ }^{56}$ Schmidt-Aßmann, Zur Funktion des Allgemeinen Verwaltungsrechts, DV (1994), p. 137, 140.

${ }^{57}$ Schmidt, Allgemeines Verwaltungsrecht (19th edition), 2016, p. 95; Ladeur, Risiko und Recht, in: Bechmann G. (ed) Risiko und Gesellschaft. 1993, p. 209.

${ }^{58}$ Schmidt, Allgemeines Verwaltungsrecht (19th edition), 2016, p. 95; Ladeur, Risiko und Recht, in: Bechmann G. (ed) Risiko und Gesellschaft. 1993, p. 209.

${ }^{59}$ According to Alexy, there are two types of leeway in law: structural and epistemic. Alexy, Theorie der Grundrechte, 1985, p. 423. It is clarified that structural leeway exist in the area where the constitution/legislation neither dictates nor forbids anything; Epistemic leeway exists in the provision of the constitution/legislation that is uncertain about its dictates, prohibitions or exemptions, for which the uncertainty of knowledge is constitutive. Besides, there are two subcategories in epistemisc leeway: empirical and normative. See: Klatt \& Schmidt, Spielräume im öffentlichen Recht, 2010, p. 5.
} 
Procedurally, based on the predominantly formulated structure of the legal norm, the "ifthen-scheme", ${ }^{60}$ and the argumentative structure of syllogism in the application of a law, the decision-making content can be categorized into the following elements ${ }^{61}$ :

(1) interpreting the legal term, which concerns the normative aspect of decision-making,

(2) identifying the facts of the individual case, which concerns the factual (cognitive) aspect,

(3) subsuming the facts of the concrete case under the constituent facts of the legal norm, eventually within the margin of appreciation if given, which involves both normative and decision-related elements,

(4) determining and substantiating the legal consequences within the leeway of discretion (Ermessen) if given, which also involves both normative and decision-related elements.

Risk precaution and danger prevention are the legal theories that systemize the doctrinal requirements for ex-ante intervention; therefore, they are also theories to guide the administrative decision-making mechanism regarding ex-ante intervention. A discussion of administrative decision-making mechanisms necessitates the incorporation of danger prevention theory. In this dissertation, the presentation of conventional administrative decision-making mechanisms incorporates danger prevention as well as risk precaution.

\subsection{Characteristic Features of Uncertain Risk of GMOs}

Conventionally, uncertain risk was ignored because it was considered as a socially necessary and therefore tolerable residual risk before its materialization. This approach is no longer appropriate for dealing with present uncertain risks. Even though side effects and consequences of technological risk can be assessed based on traditional "life experience," many of these effects and consequences are only discernible by highly specialized experts, and others cannot even be discerned at all. ${ }^{62}$ On the other hand, these new risks can create

\footnotetext{
${ }^{60}$ Schmidt, Allgemeines Verwaltungsrecht (19th edition), 2016, p. 94.

${ }^{61}$ Papier, Zur veraltungsgerichtliche Kontrolldichte, DÖV (1986), p. 623 et seq.; Pache, Tatbestandliche Abwägung und Beurteilungsspielraum, 2001, p. 42 et seq.

62 Murswiek, Die Bewältigung der wissenschaftlichen und technischen Entwicklungen durch das
} 
significant damage. Beck calls them "new risks" in order to distinguish them from classic technological "risks" (danger). While classic danger is characterized by punctuality, individuality, and concreteness, the new risk situations have a global, collective, and diffuse character ${ }^{63}$ Specifically, regarding uncertain risk, the following characteristic features are prominent: uncertain, collectively wide-ranging, manufactured, high-technological, and value-oriented.

\subsubsection{Manifestation: Epistemically Uncertain}

As mentioned earlier, uncertain risks exist in events where the probability of the occurrence and degree of a loss is unknown. It is assessed in a three-dimensional coordinate system with uncertainty, probability of occurrence, and degree of damage as coordinate draws; therefore, its most intuitive manifestation is cognitive uncertainty. Uncertainty also arises due to a lack of information or disagreement over knowledge of a particular subject. ${ }^{64}$ Due to the lack of knowledge and information to make a prognosis, it is difficult to quantify the probability of uncertain risk, the degree of damage, and causation. Besides, science and technology evolve too fast and dynamic so that rules of the causality (in the narrow sense) ${ }^{65}$ have not been determined, and the criteria of probability cannot be applied to the dynamic knowledge to establish the probability hypothesis of cause and effect either. (More information in Section 3.2.3.1.1) As a result, notwithstanding that the likelihood of occurrence and the degree of damage entailed by uncertain risk cannot be identified due to the deficit of knowledge and dynamic development of the relevant technology, ${ }^{66}$ one cannot sustain that the risk is of low probability or minor damage necessarily, simply because it cannot be scientifically determined, not to mention that, if left to its free development, it can eventually produce irreversible damage.

\footnotetext{
Verwaltungsrecht, VVDStRI Vol. 48 (1990). p. 207.

${ }^{63}$ Breuer, Disskussionsbeitrag, in: Die Bewältigung der wissenchaftlichen und technischen Entwicklungen durch das Verwaltungsrecht, VVDStRL Vol. 48 (1990) p. 278.

${ }^{64}$ Painter, Climate change in the Media, 2013, p. 11.

${ }^{65}$ Causality (in the narrow sense) describes a strict regular correspondence between cause and effect in the events. Causality (in the broad sense) includes the causality (in the narrow sense) and the theory of probability. ${ }^{66}$ Dreyer, Entscheidungen unter Ungewissheit im Jugendmedienschutz, 2018, p. 33 et seq.
} 
Because of the paramount need for the protection of safety, the possibility of damage caused by the uncertain risk cannot be legally completely ignored or categorically accepted as a residual risk before its realization. The uncertainty about GMOs is manifold, such as uncertainty about their intrinsic hazardous toxic properties ${ }^{67}$, causality between damage and activity, ${ }^{68}$ and actual exposure levels to hazard ${ }^{69}$. Most of them are connected to the lack of knowledge about future occurrences or at least the lack of secure and certain knowledge in this respect. Whether the market will develop in a certain way or whether a substance will cause cancer is often unknown.

\subsubsection{Influence: Wide-ranging}

GMOs are closely related to social life and would be deployed widely in different life aspects. Hence it has characters of a spatial large-scale and transboundary, temporal long-term and transgenerational nature, involving collective interests. ${ }^{70}$ From the spatial aspect, the uncertain risk of GMOs might be massive and global. Under conditions of internationalization and globalization of the economy, it will not be easy to cope with new technologies' challenges. The factors that determine the development of the national economy increasingly come from outside; accordingly, the risk also spreads globally. In many cases, there is only a chance to adapt to risk rather than overcome it. ${ }^{71}$ As for the temporal perspective, the influence of the uncertain risk may be long-lasting. ${ }^{72}$

\footnotetext{
${ }^{67}$ Jansen et al, Breaking Down Uncertain Risks for Risk Communication, Risk, Hazards \& Crisis in Public Policy Vol 9: 1 (2018), p. 4.

${ }^{68}$ Rogers, Risk Analysis Under Uncertainty, the Precautionary Principle, and the New EU Chemicals Strategy, Regulatory Toxicology and Pharmacology Vol. 37: 3, p. 370.

${ }^{69}$ Jansen et al, Breaking Down Uncertain Risks for Risk Communication, Risk, Hazards \& Crisis in Public Policy Vol 9: 1 (2018), p. 4.

${ }^{70}$ van Asselt \& Vos, EU Risk Regulation and the Uncertainty Challenge, in: Roeser, S. et al (eds), Handbook of Risk Theory, 2012, p. 1119; Maria, EU regulation of GMOs: Law and decision making for a new technology, 2008, p. 2; Zivier, Rechtsprobleme des Gentechnikgesetzes im Bereich der Gefahrenabwehr bei legalen Vorhaben, 1995, p. 16 et seq.

${ }^{71}$ Assmann, Neue Technologien als Herausforderung, in: Asada (ed), Das Recht vor den Herausforderungen neuer Technologien, Tübingen 2006, p. 5.

${ }^{72}$ Lee, EU regulation of GMOs: Law and decision making for a new technology, 2008, p. 2; Zivier, Rechtsprobleme des Gentechnikgesetzes im Bereich der Gefahrenabwehr bei legalen Vorhaben, 1995, p. 16 et seq.
} 
Unintentional side effects of GM technology's intended use or its products are only effective after a considerable period but of greater significance in many cases. ${ }^{73}$ Moreover, since the GMO deployment is widely and closely related to public welfare,${ }^{74}$ once the damage occurs, it will be massive, and the losses will be enormous. Therefore, a rational, risk-conscious, and effective control under the technical security law of the state must be set up to deal with the GM technology, including benefiting and simultaneously influencing citizens. ${ }^{75}$

\subsubsection{Generation: Manufactured}

The risk of GMOs is not a natural product but a result of human technological innovation. The risk arises from the active choice for the development of science and technology, i.e., the scientific and technological community is manufacturing the risk. Human decisionmaking and behavior become the main source of risk in modern society, which exceeds natural risk as to the dominant content in risk structure. ${ }^{76}$ The sociologists Giddens and Beck have all put forward the "manufacturing" characteristic of risk, which indicates a characteristic generating pattern of uncertain risk. These newer risks or hazards are manmade, catastrophic in their potentially global impact, and less amenable to control and probability calculation for both authors. ${ }^{77}$ "Manufactured risk is a risk created by the very progression of human development, especially by the progression of science and technology. It refers to new risk environments for which history provides us with minimal previous experience. We often do not know what the risks are, let alone how to calculate them accurately in terms of probability tables". ${ }^{78}$ Therefore, it is an intentionally manufactured security problem, not a safety one.

\footnotetext{
${ }^{73}$ Scherzberg, Risiko als Rechtsproblem, VerwArch. Vol 84 (1993), p. 484.

${ }^{74}$ Lee, EU regulation of GMOs: Law and decision making for a new technology, 2008, p. 19; Zivier, Rechtsprobleme des Gentechnikgesetzes im Bereich der Gefahrenabwehr bei legalen Vorhaben, 1995, p. 16 et seq.

${ }^{75}$ Scherzberg, Risiko als Rechtsproblem, VerwArch. Vol 84 (1993), p. 484.

${ }^{76}$ Adam, Beck \& van Loon (eds.), The Risk Society and Beyond, 2000, p. 2.

77 Beck, Risikogesellschaft, 1986, p. 2; Weimer, The Origins of "Risk" as an Idea and the Future of Risk Regulation, European Journal of Risk Regulation Vol. 8 (2017), p. 10 et seq.

${ }^{78}$ Giddens, Risk and Responsibility, Modern Law Review Vol. (1999), p. 4.
} 
Meanwhile, the social individual is passively and involuntarily involved in the feast of technological development and jointly is subject to uncertainty stemming from the scientific and technological progress, as well as the likelihood of damage. The new uncertain risk is "man-made". More recently, such risks have been increasing, while concerned people demand desperately the nation to safeguard the public welfare. ${ }^{79}$ Accordingly, the question of imputation and the distinction between decision-makers and those affected by their decisions are gaining importance. ${ }^{80}$ Based on the rule, "whoever is taking a risk must, therefore, expect to suffer loss, and be accountable for others". Nevertheless, this rule is difficult to achieve because, on the one hand, determining the causal relationship between the cause and the damage and therefore predicting the outcome in the shape of the damage is difficult, thus making it impossible to allocate duties of care and imputation; on the other hand, the subjects who create the risk may be organizations or of society as a whole, and everyone may be involved in it; thus, it is impossible to attribute responsibility. The Club of Rome emphatically draws a fundamental dichotomy of the human being as the cause of the environmental problem and at the same time as the victim of its consequences. ${ }^{81}$

\subsubsection{Assessment: High-technological}

The GM technique is a cutting-edge technological development. Essentially, GM technological risk is a problem of a knowledge deficit. According to the general rule of science and technology development, the progress and advancement of science and technology have the following routine: first technology being recognized by human beings and then its influence being mastered. ${ }^{82}$ Risk is a scientific concept that can be properly understood only in scientific terms. ${ }^{83}$ Therefore, the assessment and prevention of

\footnotetext{
${ }^{79}$ Hoffmann-Riem, Innovation und Recht, 2016, p. 26.

${ }^{80}$ Bora, Einleitung, in: Bora (ed.), Rechtliches Risikomanagement, 1999, p. 9.

${ }^{81}$ King \& Schneider, The First Global Revolution, 1991, p. 89.

${ }^{82}$ Klatt \& Schmidt, Abwägung unter Unsicherheit, Archiv des öffentlichen Rechts Vol. 137: 4 (2012), p. 545; Ladeur, Risikowissen und Risikoentscheidung, Kommentar zu Gotthard Beckmann, Kritische Vierteljahresschrift für Gesetzgebung und Rechtswissenschaft Vol. 74:3/4 (1991), p. 241.

${ }^{83}$ Fisher, Risk Regulation and Administrative Constitutionalism, 2008, p. 10.
} 
technological risks still depend on further understanding technology. ${ }^{84}$ The technical problem solution should be promoting a scientific approach to generate essential knowledge for decision-making. ${ }^{85}$ The main impetus behind the advancement of developments can be the chasing for an opportunity, yet in addition, endeavoring to avoid or overcome risk..$^{86}$

Besides, an important feature of the development of high technology is the deep division of labor in the disciplines, the research specialties are becoming more and more detailed, and the individual scholars' research fields are relatively concentrated so that knowledge is also in a fragmented and diffused state. Therefore, interdisciplinary dialogue is essential. Meanwhile, science must insist on its independence and integrity of scientific analysis by keeping a distance from politics and political bias to avoid being mastered and influenced. As long as the unqualified affirmation of technical progress and confidence in technical expertise prevailed among the overwhelming majority of the population, technical risk questions seemed to be "non-legal technical questions," the answers to which belonged in the hands of experts who would deal with them objectively and therefore correctly. ${ }^{87}$

\subsubsection{Evaluation: Value-oriented}

When the law or the authorities come across an area where they lack the knowledge to make decisions or regulate, they may turn to science, which provides them with secure references. However, in this day and age, it is not usually possible to find certainty by turning to science in the event of uncertainty. Science is almost always unable to give an informed opinion. ${ }^{88}$ Science, philosophy, sociology, which used to work with certainties, gradually abandon them and leave the law and the authorities alone in their decisionmaking function. A vital step in dealing with risks is assessing the risks and selecting the

\footnotetext{
${ }^{84}$ Haines, The Paradox of Regulation: What Regulation Can Achieve and What it Cannot, 2011, p. 3;

${ }^{85}$ Sunstein, Risk and Reason, 2002, p. 241.

${ }^{86}$ Hoffmann-Riem, Innovation und Recht, 2016, p. 25.

87 Murswiek, Die Bewältigung der wissenschaftlichen und technischen Entwicklungen durch das Verwaltungsrecht, VVDStRI (1990), p. 207.

${ }^{88}$ Pardo, Entscheiden und Regulieren in der Ungewissheit. Antworten und Strategien des öffentlichen Rechts, in: Darnaculleta i Gardella, Pardo, \& Spiecker gen. Döhmann (eds.), Strategien des Rechts im Angesicht von Ungewissheit und Globalisierung, 2015, p. 23.
} 
appropriate coping strategies. The more the lack of objective facts to support the risk identification and assessment, the more value-oriented evaluation is needed to enrich it. ${ }^{89}$ Therefore, uncertain risk presented by is not only an objective reality influenced by the probability and severity of the consequences but also a product of social construction, which is closely related to the perception and definition of society. It is not only produced through technical applications but also in the process of giving meaning to technology that is sensitive to potential damage, danger, or threats. ${ }^{90}$

When the authority evaluates the risk, it must take into account society's acceptance of risk. However, the acceptability of risk is deeply intertwined with broader social arrangements, and issues raised by technical risk debates are related to power and social control. Individuals accept risk depending on many things, such as institutional trust, risk allocation, the degree of voluntariness of risk-taking, and the acceptability of social arrangements on a larger scale. ${ }^{91}$ Therefore, risk evaluation should be integrated into politics, legislation, and judicial action in order to be grasped appropriately.

\subsection{Summary}

Overall, the following table enumerates several different theoretical risk-related concepts, as well as the differences between EU and German theories.

\begin{tabular}{|l|l|l|l|l|l|}
\hline & \multicolumn{3}{|l|}{ Probable damage } & $\begin{array}{l}\text { Property of } \\
\text { damage }\end{array}$ \\
\hline Law & & $\begin{array}{l}\text { Probable } \\
\text { (relatively }\end{array}$ & Possible or & Acceptable & \\
& & uncertain & possible \\
large) & damage & damage & \\
& & damage & & & \\
\hline Germany & Conventional & Danger & \multicolumn{2}{|l|}{ Residual risk } & Hazard \\
\hline
\end{tabular}

\footnotetext{
${ }^{89}$ Appel, Grenzen des Risikorechts, in: Appel Hermes \& Schönberger (eds.), FS Wahl, 2011, p. 463.

${ }^{90}$ Adam, Beck \& van Loon (eds.), The Risk Society and Beyond. 2000, Introduction, p. 2; Fisher, Risk Regulation and Administrative Constitutionalism, 2008, p. 9.

${ }^{91}$ Fisher, Risk Regulation and Administrative Constitutionalism, 2008, p. 9.
} 


\begin{tabular}{|l|l|l|l|l|l|}
\hline & $\begin{array}{l}\text { Three-tier } \\
\text { risk }\end{array}$ & Danger & $\begin{array}{l}\text { Risk (in the } \\
\text { narrow sense) }\end{array}$ & $\begin{array}{l}\text { Residual } \\
\text { risk }\end{array}$ & (Gefährlichkeit) \\
\cline { 2 - 5 } & Two-tier risk & \multicolumn{2}{|l|}{ Risk (in the broad sense) } & $\begin{array}{l}\text { Residual } \\
\text { risk }\end{array}$ & \\
\hline EU & Two-tier risk & Risk (in the broad sense) & $\begin{array}{l}\text { Residual } \\
\text { risk }\end{array}$ & Hazard \\
\hline
\end{tabular}

Due to the advent of a risk society, irreversible, large-scale damage might be caused by uncertain technological risk. In response to the intensification of the fear of society and the increasing demand for a national safety guarantee, the object of regulation and the scope of ex-ante prevention should be expanded from danger-related behavior to risk-related behavior to pursue security and stability of society. The definition of uncertain risk is significant since, when it expands the state's intervention, it may carry a new equilibrium point between freedom and safety to respect the rule of law. Obviously, it is challenging to develop a precise unified concept of uncertainty of risk, so it can only be defined in terms of its characteristics. Different risk types have different characteristics. For example, the uncertain risk associated with GMOs can be characterized as uncertain, wide-ranging in influence, manufactured, high-technological, and value-oriented. Therefore, a more rational method should be ex-ante intervention rather than ex-post remedial action based on modern risk's unique characteristics.

It should be noted that, in order to clearly contrast conventional legal concepts from new modern risk, highlight the challenges posed by such risks to the traditional legal system, and seek a corresponding reformulation of law, this dissertation adopts the terms of the German three-tier risk model, i.e., danger means a loss is to be expected with sufficient probability; a risk (in the narrow sense) refers to the loss that appears possible or uncertain, including uncertain risk that cannot be predicted with sufficient probability; the occurrence of damage that is highly improbable but cannot be ruled out in principle is classified into residual risk. 
3 Conventional Administrative Decision-making Mechanism Regarding ex-ante Prevention

As mentioned in the introduction, the risk (in the broad sense) is not a modern creation, while the problem of the tension between stability ensured by law and uncertain factuality is "an old problem of knowledge."1(more information in section 3.2.3) Traditional legal strategies, ex-ante prevention, have been developed to address the risk to ensure safety. Yet, in the context of the risk society, the traditional legal administrative decision-making mechanism and its guiding theory of danger prevention have partially failed to ensure public security or a sense of security when dealing with uncertain risks (more information in Chapter 4). As a result, they have been reformulated. However, the new administrative decision systems, i.e., the administrative risk decision-making mechanism and risk precaution theories, still encounter decision impasses, which means that the new systems may not sufficiently respond to the characteristics of uncertain risk or may not harmonize well with traditional theories, or that they are unable to address present uncertain risks. Therefore, there is a need to analyze how the traditional decision system operates and whether there is a possibility of reformulating the administrative decision-making mechanism on risk.

Overall, in the context of the slow development of traditional society, the common knowledge and experience with the rule of causality as people's reference standard of decision-making are relatively stable and easily assessable for everyone. The causal paradigm (in the broad sense) assumes that common knowledge is relatively stable and objective, and on this basis, so is the structure of the rule of causality (in the broad sense). The common knowledge would be updated by trial and error on a case-by-case basis when a deviation occurs. According to the rule of causality, the legislature can relatively objectively identify the status of conflicting interests, adequately weigh the interests, and then set rules of behavior, assign duties of care, as well as set corresponding ex-ante preventive measures or ex-post oppressive measures. Under the guidance of the objective

\footnotetext{
${ }^{1}$ Lepsius, Risikosteuerung durch Verwaltungsrecht: Ermöglichung oder Begrenzung von Innovationen?, VVDStRL Vol. 63 (2004), p. 266-267.
} 
rule of causality and legislative rules, the public can make decisions that maximize their interests. At the same time, the executive authorities can, based on reliable and accessible reference standards, predict the degree of substantial damage to legitimate interests and the probability of its occurrence and make ex-ante intervention decisions under the guidance of legislative norms. On the one hand, the administrative organ is controlled by the cognitive reference standard, i.e., common knowledge with the rule of causality for identifying factual "danger"; on the other hand, it is bounded by the normative rule, i.e., the requirement of proportional intervention in the legal danger to guarantee a balance between "public safety and freedom". On this basis, the public had a reasonable and stable expectation of whether their behavior would be interfered with by the administrative organs. Although the cognitive system and the traditional legal administrative decisionmaking mechanism based on it for ex-ante intervention have long ignored uncertain risk and knowledge deficits from the outset and classified them as residual risk, ignoring uncertain risk by the causal paradigm (i.b.s), especially by the probability assumption paradigm, did not shake the factual rationality and the stability of the law. This is because uncertain risk and knowledge are only very slowly entering the realm of human cognition. Human society can mostly afford to pay the price of trial and error. Identifying "danger" based on the common knowledge and experience with the rule of causality is relatively objective and predictable, thus ensuring the factual rationality of ex-ante intervention by the administrative authorities and further guaranteeing the balance between "freedom and public safety".

After a first step, i.e., analyzing the characteristics of uncertain risk, the second step will be reviewing the conventional administrative decision-making mechanism on risk. Considering that the doctrinal theory of danger prevention is an essential legal theory to shape and guide the administrative decision-making mechanism, a brief introduction is necessary (section 3.1). Section 3.2 reviews how danger prevention is implemented in the administrative decision-making mechanisms and how the decision-making mechanism operates. 


\subsection{Danger Prevention as the Legal Task of ex-ante Intervention}

Danger prevention systematizes the doctrinal requirements for ex-ante intervention activities, which is designed to protect the public interest through administrative authority preventively intervening in the object "danger situation". Danger prevention exists mainly in police law, regulatory law, and technical security law. It is closely linked with the classic police law concept of danger. ${ }^{2}$ The doctrinal theory of danger prevention mainly includes the following contents that: first, the intervention aims to protect public and private legal interests from being damaged; second, the competent administrative authority is only empowered by the legislation to take appropriate ex-ante intervening measures when the risk situation crosses the "danger" threshold, i.e., the doctrinal concept danger is the criterion activating the police or competent authority to take measures of preventive intervention; ${ }^{3}$ third, the measures of intervention are limited to avoid the materialization of damage of danger or to end disturbances that have already occurred. ${ }^{4}$

Regarding the relevant threshold, danger is a "situation", judging by a cognitive reference standard, i.e., the rule of causality existing in the experience and common knowledge, and by legal rule, which gives rise to the concern that certain present states are probable to cause damages to a legitimate interest and shall be prevented by the authority. ${ }^{5}$ The concept of danger is characteristically constituted by two elements: an assessment that indicates the seriousness of the extent of the likely damages and an assumption of its occurring probability. Besides, the determination of danger to be regulated is a combination of cognitive (factual) assessment and normative evaluation. The cognitive assessment refers to identifying the probability of occurrence and possible damage result from the factual situation, which is based on the cognitive reference standard, being experience and common knowledge with the rule of causality in the broad sense. The "rule of causality" in the broad sense (including causality in the narrow sense and the assumption of probability) means that a cause-results relationship chain as experienced in the past, including the

\footnotetext{
${ }^{2}$ Scherzberg, Risiko als Rechtsproblem, VerwArch. Vol 84 (1993), p. 484; Drews, Wacke, Vogel \& Martens, Gefahrenabwehr (9th edition), 1986, p. 232.

3 Erichsen, Der Schutz der Allgemeinheit und der individuellen Rechte durch die polizei- und ordnungsrechtlichen Handlungsvollmachten der Exekutive, VVDStRL Vol. 35 (1977) p. 185 et seq.

${ }^{4}$ Delhey, Staatliche Risikoentscheidungen, 2014, p. 81.

${ }^{5}$ Scholz, Die polizeirechtliche Gefahr, VerwArch 1919, p. 15; Ladeur, Das Umweltrecht der Wissensgesellschaft, 1995, p. 11; Götz, Allgemeines Polizei- und Ordnungsrecht (14th edition), 2008, p. 42.
} 
related knowledge, may occur in the future, i.e., be repeated. The knowledge with the content of regularity of "cause-effect" organized by the cognitive causality paradigm provides the "rule of causality" with default regularity and certainty characteristics. The knowledge and experience with "cause-effect" regularity act as the reference standard for predicting and assessing the probability of occurrence and extent of the damage for the concerning situation. The normative evaluation refers to delineating the scope of the danger to be prevented by legal measures based on an evaluation of affected interests. A vital principle in normative evaluation is the "inverse proportion" rule (Je-Desto-Formel) between the probability of occurrence and extent of damage, which means that the greater is the degree and intensity of the possible harm, the lower are the requirements for the degree of probability of the occurrence. At the same time, any "likelihood of damage" that does not fall under the legal scope of danger, for example, a low probability of occurrence, a compound, future, uncertain possible damage, is assumed to be a "residual risk" 6 on the basis of "practical grounds" 7 (praktische Vernunft). Conversely, the danger is a possible damage that is not socially acceptable.

The concept of danger can be understood as a hinge formula that describes the link between the formation of social experience and the law. ${ }^{8}$ It can be seen that danger prevention is the principle and mechanism of balancing "public safety and individual liberty" in traditional public law. The strict doctrinal limitation of danger facilitates adequate control of the state's ex-ante intervention in individual freedom based on relatively subjective predictions and functions as a practical balance between liberty and security.

\subsection{Administrative Decision-making Mechanism on Danger Prevention}

As identified in section 2.1.2, the administrative decision-making mechanism encompasses three constituent elements: aims of value, operating principles, and specific content of

\footnotetext{
${ }^{6}$ Di Fabio, Gefahr, Vorsorge, Risiko: Die Gefahrenabwehr unter dem Einfluss des Vorsorgeprinzips, Jura 1996, p. 566 et seq.; Wahl \& Appel, Prävention und Vorsorge: Von der Staatsaufgabe zur rechtlichen Ausgestaltung, in: Wahl \& Appel (eds.), Prävention und Vorsorge, 1995, p. 92.

${ }^{7}$ Wahl \& Appel, Prävention und Vorsorge: Von der Staatsaufgabe zur rechtlichen Ausgestaltung, in: Wahl \& Appel (eds.), Prävention und Vorsorge, 1995, p. 89.

8 Ladeur, Risikobewältung durch Flexibilisirung und Prozeduralisierung des Rechts, in: Bora (ed.), Rechtliches Risikomanagement, 1999, p. 50-55.
} 
decision-making (including the substantive decision-making standard, participating subjects, and procedure), which is guided and controlled by the doctrinal theory of danger prevention. The aim of value of the decision-making mechanism for danger prevention is to balance freedom and security. As regards the operating principles, they include the rule of law, rationality, etc. The specific content of decision-making means that, under the regulatory framework, the competent authority makes and justifies ex-ante intervention decisions, i.e., applying the law.

\subsubsection{Aims of value}

There are two main guiding aims of value in the administrative decision-making mechanism for danger prevention. On the one hand, it legitimatizes the authority to take proportional intervention in individual freedom to ensure social security. On the other hand, it eliminates the possibility of arbitrary power encroaching on legitimate freedom. These are the two sides of the same coin with a dialectical equilibrium relation inherent in police law and regulatory law, guiding the institutionalization and operation of the decision-making mechanism pertaining to danger prevention. This bipolar orientation of public law is geared to weighing up freedom as guaranteed by fundamental rights against the public interest in efficient danger prevention.

\subsubsection{Guarantee of Security}

The most direct functional aim of decision-making on danger prevention is "public security" and - at least in part- "public order." 9 There is unanimous agreement in Germany ${ }^{10}$ that there are three constituent categories of interests to be protected, which are in a reciprocal relationship to one another ${ }^{11}$ : (1) The objective legal order in the sense of all written legal norms at (constitutional) legal or sub-legal level ${ }^{12}$, (2) individual and collective legal

\footnotetext{
9 Thiel, Die "Entgrenzung" der Gefahrenabwehr, 2011, p. 52.

${ }^{10}$ Pieroth,et al, Polizei- und Ordnungsrecht (6th edition), 2010, chapter 8 No 3 et seq.

${ }^{11}$ Möstl, Die staatliche Garantie für die öffentliche Sicherheit und Ordnung, 2002, p. 131.

12. Denninger, Gefahreabwehr, in:Lisken \& Denninger (eds.), Handbuch des Polizeirechts (4th edition), 2007, p. 302; Pieroth,et al, Polizei- und Ordnungsrecht (6th edition), 2010, chapter 8 No 10 et seq.
} 
interests ${ }^{13}$ (linked to individual legal interests through the collective perception or otherwise normatively guaranteed) as well as (3) the state and its institutions and events in the meaning of protection of the "functional capacity" of the state and other authorities. ${ }^{14}$

\subsubsection{Control of the Administration and Protection of Freedom}

According to the "general view," the danger situation shall be tackled before its' realization in the shape of damages; correspondingly, the behavior causing the danger shall be tackled, i.e., the personal freedom to conduct the danger-related act shall be restricted in a certain way. Necessary is thereby an interest of the state and the community in realizing the common good. Besides, the restriction of civil liberties is only permitted in "danger" situations. ${ }^{15}$ Government measures are necessary for effective danger prevention only when the possible extent of damage and probability of occurrence reaches a normatively defined magnitude, i.e., the threshold of danger is exceeded. ${ }^{16}$ Based on this, security law fulfills the vital task of balancing freedom and security. Danger prevention actually and largely affects civil liberty or various other fundamental rights, although its task as such is, without any doubts, indispensable for the state and the community. ${ }^{17}$ Since danger is the specific object of the measures taken by the administration to ensure safety, in turn, it can be considered that the danger situation performs the function of describing the scope of the administrative duties to keep the social order. Doctrinal danger as a core element of fact describing the task of order administration was - and still is today - limited to restrain the police from welfare state involvement - unless they have an explicit statutory mandate to do so. ${ }^{18}$ As the task of the police, ex-ante danger prevention is limited to the prevention of damage. ${ }^{19}$ Therefore, police law and other regulatory laws oriented at ensuring security have the fundamental task of balancing the constitutional goals of freedom and security ${ }^{20}$.

\footnotetext{
${ }^{13}$ Gusy, Rechtsgüterschutz als Staatsaufgabe, DÖV (1996), p. 573 et seq.; Pieroth et al, Polizei- und Ordnungsrecht (6th edition), 2010, chapter 8 No 8-9.

14 Thiel, Die "Entgrenzung" der Gefahrenabwehr, 2011, p. 53

${ }^{15}$ Park, Wandel des Klassischen Polizeirechts zum neun Sicherheitsrecht, p. 182.

${ }^{16}$ Brenner \& Nehrig, Das Risiko im öffentlichen Recht, DÖV (2003), p. 1024.)

${ }^{17}$ Byungwoog, Wandel des klassischen Polizeirechts zum neuen Sicherheit, 2013, p. 181.

18 Erichsen, Der Schutz der Allgemeinheit und der individuellen Rechte durch die polizei- und ordnungsrechtlichen Handlungsvollmachten der Exekutive, VVDStRL Vol. 35 (1977) p. 171. et seq.

${ }^{19}$ Darnstädt, Gefahrenabwehr und Gefahrenvorsorge, 1983, p. 22 et seq.

${ }^{20}$ Byungwoog, Wandel des klassischen Polizeirechts zum neuen Sicherheit, 2013, p. 181; Trute, Grenzen des präventionsorientierten Polizeirechts, DV Vol. 42 (2009), p. 85 et seq.
} 
In the process of danger prevention, the police is to prevent a behavior or freedom, which is an "exception" and a deviation from the liberal rule. The importance of "weighing" between the value of security to be protected and freedom that can be impaired by preventing a potentially harmful act becomes apparent precisely in borderline cases, especially in the case of technical dangers that can never be excluded entirely. Classical administrative law was functionally oriented at limiting the police administration and facilitating the fulfillment of state tasks, such as danger prevention, ultimately balancing the constitutional goals of freedom and security ${ }^{21}$. In the danger prevention decision, the doctrinal concept of "danger" situation is the threshold for the administration taking an exante prevention action ${ }^{22}$, the trim point between liberty and security set by the legislature. Police and other security authorities performing the security task need to operate within the boundary of a "danger" situation in accordance with the rule of law, which also means respecting the need for balancing the interest in protecting security and preservation of liberty in proportion ${ }^{23}$. This is to say, the concept of danger is functioning as a "borderline concept," enabling, in particular, coordination between private action and public measures.

The identification of "danger" based on common knowledge with a relatively high degree of stability and certainty (see Section 2.1.1) can provide a sufficient rationale and objective preconditions for the state to make intervention decisions in advance. However, the state's actions can be reviewed and monitored by a relatively scientific and objective standard. It is underpinned by "a larger number of cases." Leisner considers the classical prevention of danger in the form of police law in the broader sense to be the "firmest achievement of our (German) rule of law." ${ }^{4}$ Therefore, the classic legal pattern of ex-ante intervention, "danger prevention," has the significance of concurrently authorizing the state to preserve security and bounding it to refrain from illegally infringing upon citizens' freedom. For this reason, it is consequently promoted and applied until now.

\footnotetext{
${ }^{21}$ Trute, Grenzen des präventionsorientierten Polizeirechts, DV Vol. 42 (2009), p. 85 et seq.

${ }^{22}$ Horn, Vorbeugende Verbrechensbekämpfung, in: FS Schmitt Glaeser, 2003, p. 451

${ }^{23}$ Möstl, Die staatliche Garantie für die öffentliche Sicherheit und Ordnung, 2002, p. 197; Byungwoog, Wandel des klassischen Polizeirechts zum neuen Sicherheit, 2013, p. 181

${ }^{24}$ Leisner, Disskussionsbeitrag, in: Die Bewältigung der wissenchaftlichen und technischen Entwicklungen durch das Verwaltungsrecht, VVDStRL Vol. 48 (1990) p. 270.
} 


\subsubsection{Operating Principles}

As for the operating principles for decision-making, there are two categories fundamental to the fulfillment of public tasks in the modern constitutional state: rationality and the rule of law ${ }^{25}$. Both are of legal significance, but rationality is usually in default in legal practice. Some other principles, such as proportionality and stability, are vital for fulfilling the relevant administrative tasks, but because they are not so closely related to the risks and challenges, the dissertation would not discuss them.

\subsubsection{Rationality}

Rationality is too abstract a concept that it could be easy to be conceptualized. When integrating it into decision-making, it at least entails the requirement that valid, objective, and relatively comprehensive data or knowledge should be the basis of making a choice. This is to say, rationality is closely linked to informed knowledge. According to Scherzberg, rational action, however, in the form of purposeful rationality, depends on empirically founded assumptions about the suitability of a means to achieve the purpose. ${ }^{26}$ The founded assumption is to be based on the knowledge to conduct a rational action. ${ }^{27}$ In Germany, the Federal Constitutional Court also emphasizes the connection between knowledge and rationality of decision-making when it speaks of a duty addressed to the organs of state "to procure the information necessary for rational and planned state action". ${ }^{28}$

Generally, the rule of law also postulates an informed statehood when making the decision for danger prevention, which means the structural profile of relevant knowledge should be considered. According to Max Weber's topos, "bureaucratic rule by virtue of knowledge," knowledge was taken up as the goal and completion of a state administration oriented at

\footnotetext{
25 Wollenschläger, Wissensgenerierung im Verfahren, 2009, p. 3; Schmidt-Aßmann, Das allgemeine Verwaltungsrecht als Ordnungsidee, 2006, p. 84 et seq.

${ }^{26}$ Scherzberg, Risikosteuerung durch Verwaltungsrecht: Ermöglichung oder Begrenzung von Innovationen?, VVDStRL Vol. 63 (2004), p. 246.

${ }^{27}$ On the functional component of the concept of knowledge as a prerequisite for rational action, especially Stehr, Wissen, in: Christoph, Engel (ed.), Wissen, Nichtwissen, Unsicheres Wissen, 2002, p. 20; Fassbender, Wissen als Grundlage staatlichen Handelns, in: Isensee \& Kirchhof (eds.), HdBStR Vol. 4, § 76 No 1.

${ }^{28}$ BVerfGE 65, p. 1 (3).
} 
rationality and effectiveness in modern society. ${ }^{29}$

\subsubsection{Rule of Law}

The rule of law, in short, denotes action bounded by law, which contributes to the expectation and the establishment of predictability in society. One of the core values of law is the establishment of predictability, legal certainty, and accountability. ${ }^{30}$ The rule of law is conducive to the realization of rationality and vice versa. In order to avoid arbitrariness given the uncertainty and value-dependency of danger assessment and to establish factual adequacy, the rule of law demands a "rational" decision in procedural and material respects according to traditional understanding.

\subsubsection{Specific Contents/ tasks}

The specific content of the decision-making mechanism is the vital element that prescribes the administrative authority to comply with the provided regulatory requirements, to produce and justify a decision as a result of well-planned procedures of information acquired $^{31}$ under the guidance of the aims of value and applicable principles. In relation to danger prevention, the administration needs to investigate the factual information, assess a specific behavior or situation as to whether it conforms to the doctrinal notion of "danger" threatening the legally protected interests, and decide whether and how to take measures of ex-ante intervention. It has to follow the substantive decision-making standards and procedural requirements, as well as organize the participation of the relevant subjects (persons or organizations) under the guidance of the functional aims and operating principles. Procedurally, the administrative authority has to interpret the norm first and then obtain information about the individual facts. At last, it connects the norm with the factuality in the form of subsuming the facts of the individual case under the constituent facts of the legal norm (Tatbestand), i.e., danger. Finally, it has to make a decision, i.e.,

\footnotetext{
${ }^{29}$ Wollenschläger, Wissensgenerierung im Verfahren, 2009, p. 4.

${ }^{30}$ Spiecker gen. Döhmann, Uncertainty in EU Technology Regulation: How law making and law enforcing matters, in: Weimer, Cseres \& Eckes (eds.), The Rule of Law in the Technological Age: Challenges and Opportunities for the EU: collected papers ACELG 6th Annual Conference, 2017, p. 38.

${ }^{31}$ Wolff, Bachof \& Stober, Verwaltungsrecht (6th edition) Vol. II, 2000, p. 285.
} 
determine the corresponding legal consequence according to substantive decision-making standards. ${ }^{32}$ The participating subjects are the subjects concerned, interested, or otherwise involved, such as the addressee, members of the public (concerned), and also particular scientific experts. Substantive decision-making standards include both the factual-level cognitive rules to identify the factual situation (cognitive assessment) and the normativelevel requirements for subsuming the facts under the relevant legal term of danger (normative evaluation) and determining the corresponding ex-ante preventive measure.

\subsubsection{Substantive Rules}

Generally, the cognitive assessment rules for danger play a role in the process of obtaining information about the individual facts, i.e., investigating the factual situation and predicting the probability of occurrence and extent of the damage based on the common knowledge and experience with the rule of causality. The process of obtaining information represents a fundamental component of the administrative procedure before a concrete decision is made, ${ }^{33}$ whereby the addressee may also supply facts or experts be involved to investigate and analyze the facts. The normative evaluation rule for determining whether there is a danger and choosing measures of intervention appears in the process of subsumption of individual facts, i.e., determining whether the investigated situation falls under the statutory term "danger", and determination of the final decision, especially deciding on measures, respectively.

\subsection{Cognitive Rule for Factual Rationality}

The cognitive rule or reference standard for danger prevention is constituted by knowledge and general life experience with the rule of causality in the broad sense, which provides relative objectivity, certainty, regularity, and rationality for assessing the relevant situation. Generally, the reference standards do not exist naturally but arise from the process: at first,

\footnotetext{
${ }^{32}$ Schmidt, Allgemeines Verwaltungsrecht (19th edition), 2016, p. 95; Ladeur, Risiko und Recht, in: Bechmann G. (ed.) Risiko und Gesellschaft. 1993, p. 209.

${ }^{33}$ Wollenschläger, Wissensgenerierung im Verfahren, Tübingen 2009, p. 8-9; Holoubek, Die Bedeutung des Amtsermittlungsgrundsatzes, in: Hoffmann-Riem \& Schmidt-Aßmann (eds.), Verwaltungsverfahren und Verwaltungsverfahrensgesetz, 2002, p. 194.
} 
human beings cognize the causal chain in nature in the form of knowledge and experience, and then, based on cognition, organize them with the causality paradigm and turn them into the rule of causality. How exactly cognitive rules are established and how they serve as criteria for assessing the fact-side of "danger" will be described in the following section.

\subsection{Generation of the Cognitive Reference standard}

\subsection{1 Relative Stability of Knowledge and Experience}

Mastering the natural rules is the first step for man to transform nature. In determining danger, the reference standard that provides guidance for human behavior and guides "danger" assessment is essential knowledge and experience ${ }^{34}$ about the natural rules, which are mastered by man through various forms of exploration, such as research, experiments, expeditions, etc. Therefore, to know the reference standard for "danger" identification, we must first briefly understand its component, i.e., natural rule in the form of the causal chain.

According to the general view, the world is dominated by natural rules, and everything is in a system of causal chains with its own intrinsic rules. Parts of the world are cognized by humans, and some parts are not. The world that humans have known comprises contingent (causal) events and necessary (causal) events. The necessary causal relationships that we recognize, i.e., a cognition whose intrinsic regularity humans have grasped, is taken by us as the regularity, constructing order. Contingent (causal) events, i.e., a cognition whose intrinsic regularity humans have not yet grasped in the present, are classified as chaos. Chaos did not escape description by the rule of nature but escaped submission to the regularity people have learned. ${ }^{35}$ All human cognition to order as well as chaos present itself in the form of knowledge and experience, such as science, technology, etc. However, chaos and order are sharply separated from each other in traditional society before the risk society. ${ }^{36}$ Of course, their boundaries are not fixed. As human exploration expands and accumulates more experience and knowledge, some unrecognized regularity is gradually

\footnotetext{
${ }^{34}$ It should be noted here that this dissertation does not distinguish between knowledge, information, and cognition; they collectively refer to the information available to humans, regardless of whether they include the rule of causality or not.

35 Ladeur, Das Umweltrecht der Wissensgesellschaft, 1995, p. 22.

${ }^{36}$ Ladeur, Das Umweltrecht der Wissensgesellschaft, 1995, p. 79.
} 
grasped. Thus, the scope of the order is continually expanding. Simultaneously, more and more chaos may be discovered. When humans perceive new chaos and uncertainty, it means that the boundaries of people's cognition are expanding.

Knowledge and experience about causal chains can provide guidance for people's behavior only if it is organized by a causal paradigm or model and is distilled into the rule of causality. Specifically, the causality model organizes the regular causal chains in knowledge and experience and then analytically decomposes them into many individual stable short casual-effect relationships with regularity, i.e., many independent events. With the causal paradigm pre-structuring options and problems, assuming the predictability and repeatability of "cause-effect" chains of events, the events with regular "cause-effect" relationships can happen over and over again. The repeatable "cause-effect" relationships are called the rule of causality. In other words, the rule of causality is a regular phenomenon that stable, independent chains of events in the form of "cause-effect" content can repeat, from which the reference standard for identifying "danger" comes. It indicates the notion of repeatable events whose future occurrence can be controlled, i.e., either avoided or accepted as a type. The knowledge and experience with the rule of causality are both a guide for individual decision-making and the basis for law to establish attribution rules. On the one hand, the rule of causality is socially pragmatic, needed to simplify the "cause-effect" relationship for attributions, which are intended to make action possible through the distribution of responsibility and resources. ${ }^{37}$ On the other hand, it allows decision-making by anticipating future knowledge.

Compared to modern society, in traditional society, human exploration of the objective world was relatively slow, human technology to transform nature was also very backward, the rate of unknown factors being identified by a human was also slow, and the scale of uncertainties or chaos entering the scope of human life was relatively small. Therefore, the rule of causality established by people on the basis of accumulated experience and knowledge is not easily overturned, thus guaranteeing the stability of society and people's expectations of behavior. The legal rules established on this basis also have stability and

${ }^{37}$ Ladeur, Das Umweltrecht der Wissensgesellschaft, 1995, p. 16. 
legitimacy. But, in order to enhance the ability to behave and improve the quality of life, human beings need to expand their cognitive boundaries and master more of the rules inherent in nature.

\subsection{2 The Causal Paradigm}

The rule of causality can act as a reference standard for people's future decisions. It is generated from the knowledge after being organized by the causal paradigm or model. The causal paradigm or model simplifies the causal chain and establishes many independent regular causal relationships, i.e., the rule of causality. Therefore, the causal paradigm is a fundamental instrument in the whole cognitive system. In this respect, two concepts must be generally distinguished: the causal chain and the causal paradigm or model. The causal chain is complex, intertwined, and lengthy relationships exist among events in the natural world. In contrast, a causal paradigm or model is an instrument or mechanism used to selectively cut off the infinite causal chains and establish an individual event in the form of a "cause-effect" relationship.

The causality model includes two paradigms: the causal paradigm in the narrow sense (i.n.s.) and probability theory. The causal paradigm (i.n.s.) is applied to organize the knowledge and experience to construct the rule of causality (i.n.s.), which describes a strict regular correspondence between cause and effect in the events. By breaking off the infinite connection, the causal paradigm can form a natural gradation of the complexity of the causal chain in knowledge and experience, and construct many short individual "causeeffect" relationships, i.e., independent events. Therefore, it is also called the mechanism of event construction in the form of the link between cause and effect based on the objective causal connection of events. After the "natural gradation of levels of complexity," each event is a ramification for action in the natural network that would have to be examined as candidates for the status of cause in the processes taking place at that level." ${ }^{38}$ As for how to cut off the infinite causal chain, it is shaped by cultural choice and conventionalized social ideas, ${ }^{39}$ i.e., it is strongly associated with normative and conventionalized social ideas. Thus,

\footnotetext{
${ }^{38}$ Krüger, Kausalität und Freiheit, Neue Hefte für Philosophie 1992, p. 13.

39 Ladeur, Das Umweltrecht der Wissensgesellschaft, 1995, p. 15; Lübbe, Die Theorie der adäquaten Verursachung, ZAW 1993, p. 87.
} 
although the causal paradigm organizes an objective causal chain, it also incorporates normative elements to form independent individual "cause-effect" relationships.

The theory of probability is also a paradigm organizing knowledge and experience to establish an independent causal relationship. It constructs the rule of causality in the broad sense (i.b.s), which expresses the understanding that the cause-effect relationship is not entirely fixed but remains stable within a specific range of fluctuation. ${ }^{40}$ For example, one cause may correspond to several possible outcomes, and the occurring probability of each outcome may be perceived differently, which can be estimated from experience and knowledge. Thus, the probability paradigm establishes the probability of correspondence between a cause and an effect. The theory of probability is meaningful to creating regularity in systems that are so complicated that there are various branching points for different event sequences but which still exhibit a certain regularity.

In particular, the probability paradigm includes the strict probability model and the probability assumption model. The strict probability model assumes that all possible causes and effects are known, ${ }^{41}$ exhibiting a definite probabilistic relationship. For example, if there are 40 ping pong balls in the box, 20 of which are white and 20 are black, the probability of drawing white is definitely $50 \%$. Nevertheless, this strict probability model is impractical for organizing the knowledge and experience to construct the rule of causality because, in general life, the causes and results presented by the acquired knowledge are, in principle, not complete; thus, a precise probability of a cause in relation to a result cannot be calculated. In contrast, sometimes, forced by the scarcity of time and the need for making a decision, the paradigm of probability assumption selects a reference group from the accumulated knowledge and experience, namely "canonized examples", assume the group to be comprehensive and typical so as to use it as a basis for calculating the probability of correspondence between a cause and an effect. As a result, the assumed probability between cause and effect is constructed based on the moment's knowledge. Therefore, the probability assumption is not based on a precisely clear cause-effect chain but the

\footnotetext{
${ }^{40}$ Krüger, The Slow Rise of Probabilism, in: Krüger (ed.), The Probabilistic Revolution, vol. 1, Cambridge/Mass. 1987, p. 59.

${ }^{41}$ Kyburg, Science and Reason, New York/Oxford, 1990, p. 41 et seq.
} 
determination of a contribution from the typified event/ group or situational knowledge, i.e., "canonized examples."

The comprehensiveness of knowledge is conducive to the rationality of decision-making. However, it is unrealistic to acquire complete knowledge under limited time for decisionmaking, so we need to make a decision based on incomplete information within a limited time. This is why the probability assumption model is more practical and widely utilized than the strict probability model. At this point, social learning always requires a stop rule, which enables action even on the basis of incomplete knowledge. A stop rule is a kind of practical self-imposed constraining rule, which breaks off the search for further knowledge, ${ }^{42}$ and is formulated based on experience, context-independent belief assumption as well as context-dependent intention. ${ }^{43}$ Distinctions are defined by using stop rules, limiting the scanning of relational networks for further linking possibilities, that is, combining selection and variation. This plays a crucial role in stabilizing the reference basis of the decision, provisionally ending the search for a knowledge base under time pressure, and assuming the risk of a decision on an inevitably incomplete basis, thus institutionalizing incomplete knowledge as a possible basis for decision-making. Besides, the stop rule tied to experience is a confidence-building rule that suggests establishing routines rather than theoretical questioning. Despite the reduction of the claim of rationality, the stop rule can compensate decision-making with result expectation. It is because the stop rule, by cutting off the search for information, helps to establish the probability assumption of cause-result as soon as possible so that social agents can reasonably expect the consequences faced by their actions and make more rational decision-making.

Though knowledge is not permanently static and social cognition is also developmental, the recognized rules of causality, especially those established by the probability paradigm, would be updated or falsified. They take place relatively slowly and happen in the form of trial and error, i.e., point-by-point variation. The later deviation or update is ignored, while causality in the narrow sense and probability assumptions organize the current knowledge

\footnotetext{
42 Spiecker gen. Döhmann, Rechtliche Strategien und Vorgaben zur Bewertung von Nichtwissen, in: Hill \& Schliesky (eds), Management von Unsicherheit und Nichtwissen, 2016, p. 105.

${ }^{43}$ Bora, Einleitung, in: Bora (ed.), Rechtliches Risikomanagement, 1999, p. 9.
} 
and experience. Society could also accept the risks (disorder) contained therein as a conceptually incomprehensible "rest" limited by the decentralization of experience and learning by error. In case of an error, a slight variation of the knowledge base, the change of assumption will be necessary, which can be used for future decisions. That is to say, the supply of new knowledge and the generation of the new rule of causality stem from retrospective learning and through coincidences.

At this point, another problem is also encountered: how to select and complete a reference group for the determination of causation and to delimit the suitable group? This is a subjective and normative choice. The population of reference groups is an open class of typical events, which is incomplete and functions so as to form "canonized examples." The "canonized examples" can be followed by new variants, the testing of which either confirms the durability of the decision-making knowledge or suggests its differentiation or revision by modifying the population. The probability is dynamic and can also be modified and renewed after generating new variations through practical action, i.e., an equilibrium between stability and learning ability through coincidences. However, since knowledge for making the probability assumption is scattered over a multitude of participants whose knowledge base is not centrally available or amenable to be aggregated, ${ }^{44}$ the coordination of shared knowledge has been conventionalized in the social rules, such as the legal system.

In traditional society, knowledge and experience are scattered across society and evolve relatively "gingerly". The causality model (i.b.s) and its gradations of different complexity levels, in conjunction with structure-forming stop rules, guarantee a kind of "default reasoning" that constructs connectivity of events within a time assumed to be homogeneous, which is designed for repeatability. With the repeatability, the causality contributes to other institutions, such as law, to establish the social expectation and action rule, consequently, form an organized society. The reason why regularity or order can be established is that the knowledge and experience appear as causality in the form of "causeresult," which facilitates predicting the result of one's own behavior and allows the formation of social expectation of result and possible corresponding responsibility

${ }^{44}$ Ladeur, Das Umweltrecht der Wissensgesellschaft, 1995, p. 25-26. 
prescribed by pertinent legislation, religion or ethics, etc. Accordingly, this error correction can direct practical social action, i.e., organized knowledge becomes an action-orienting rule. Admittedly, since the causal probability is based on partial information, this assumption may be proven wrong following the increase in knowledge and experience. In other words, the causal relationship is falsified; at the same time, a new practical causeresult relationship can be formed.

The process of trial and error is slow, and its form is case by case that the cost of trial and error is moderate and socially acceptable. Therefore, the assumed probabilities are relatively stable regularities and not quickly rejected. Thus, they still function as regularity to inform people's behavior and decisions until they are dismissed by newly discovered "deviation" in the trial-and-error procedure. In other words, if the knowledge has been applied to practical action and its durability verified, it is regularity. If the verification fails, the practical experience spontaneously adapts to new development and adjusts the previous assumption of the probability of the knowledge. Correspondingly, the social knowledge evolution formularizes itself as a self-description and self-reinforcement pattern and operates in a relatively linear equilibrium model. The formation of experience and knowledge is a self-reinforcing process of self-organization and self-stabilization. They spread continuously and gradually among the public.

\subsection{The Content of the Cognitive Reference Standard}

The prerequisite for identifying whether behavior can be subsumed as a "danger" regulated by law is a judgment of factual "danger," which is regarded as an act or situation that may cause damage. Generally, it is the spontaneously accumulated "average of experience" or "common knowledge" with the rule of causality functioning as the reference standard for identifying the danger. When public law institutionalizes "danger" as the threshold for the authority to ex-ante intervene in an activity and to prevent it from realizing the damage to the legally protected interest, it has implicitly referred to common knowledge relating to the "danger". Common knowledge, organized by the causal paradigm and probability paradigm, pervades all social systems. It includes the regularity of events rules and then the direct prognosis of certain situations leading to the damages and their probability, i.e., they 
functionally act as the preliminary standard for identifying dangerous situations. Therefore, common knowledge can be used as a reference basis for the administrative authorities to judge the likelihood of occurrence of a "danger" situation and the degree of damage.

The judgments of two elements of danger are based on the "average wealth of experience" 45 and "common knowledge" institutionalized in the deep structure of society ${ }^{46}$, which are organized in the form of causality by a relatively fixed system of beliefs, imaginations, and expectations, and are designed for continuous practical integration of new ones. ${ }^{47}$ Conventionalized knowledge, by forming a framework for options, restricts the possibility of options and, at the same time, allows more possibilities within this spectrum by limiting mutual mistrust. ${ }^{48}$ It is mainly the common knowledge and average experience that is the reference point for danger judgments because they enable the formation of social expectations and facilitate the construction of social order. "Average wealth of experience" is accessible to the police and public, even if partly only with the help of experts, and is functioning as a "uniformity" basis for public or private decision-making. The objectivity of judgment of the "danger" situation is demonstrated not only by the fact that it is induced by a larger number of cases justifying the concern of damages but also by that a "judgment which corresponds to the facts" can be formed, which every experienced man reaches evenly. ${ }^{49}$ If the available knowledge does not indicate a relative probability of harm, the action causing the danger situation is not considered as dangerous. ${ }^{50}$ Therefore, a danger that is not recognizable to anyone is not a danger in the legal sense. ${ }^{51}$

\subsection{Rules for Normative Legitimacy}

The normative rule is the criteria for evaluating and prioritizing values, which imply subjective choice and are mainly found in norms and doctrinal theories. The cognitive rule and the normative rule are interrelated. Indeed, the normative rule is fundamentally bound

\footnotetext{
${ }^{45}$ Ladeur, Das Umweltrecht der Wissensgesellschaft, 1995, p. 12.

${ }^{46}$ Ladeur, Das Umweltrecht der Wissensgesellschaft, 1995, p. 9.

${ }^{47}$ Ladeur, Das Umweltrecht der Wissensgesellschaft, 1995, p. 9.

${ }^{48}$ Ladeur, Das Umweltrecht der Wissensgesellschaft, 1995, p. 29.

${ }^{49}$ Ladeur, Das Umweltrecht der Wissensgesellschaft, 1995, p. 12.

50 Ladeur, Das Umweltrecht der Wissensgesellschaft, 1995, p. 14.

${ }^{51}$ Ladeur, Das Umweltrecht der Wissensgesellschaft, 1995, p. 12.
} 
by the cognitive rule. It is supposed to ensure constant monitoring of the effects of legislation and its improvement and update correspondence. ${ }^{52}$ However, it is influenced by historical, cultural, political, geographical, temporal, and other factors. The higher the lack of objective rationality of the cognitive rules, the stronger is the need to supplement the normative rules, both for the legislature and the executive. A possible damage event is not necessarily included in the scope of legal danger. After judging the facts of the damage and the possibility of occurrence, the administration shall decide according to normative criteria, i.e., legal norms and theory, on whether or not the concerning situation is a legal danger that shall be tackled ex-ante. Lawmakers need to thoroughly weigh the conflicting interests and decide what kind of dangerous behavior to consider as danger in the legal sense. Based on "the average of experience" or "common knowledge" with the rule of causality, legislatures, after weighing the conflicting interests, set rules of behavior, assign duties of care, and set corresponding ex-ante or ex-post enforcement measures by weighing conflicting interests. Besides, as mentioned above, the rule of causality, structured by the probability paradigm, is a kind of assumption that may be changed as knowledge expands. Correspondingly, the rules of behavior based on such regularity must also be adjusted. This is a kind of legal renewal in development or the ability to learn.

On the premise of fully respecting the principles of democracy, liberal freedoms, and the rule of law, the legislature formulates provisions in as much detail as possible to define the scope of intervention by the administration so as to achieve a balance between maintaining public safety and individual freedom. Besides, a potential danger beyond the boundary of "practical reason" is to be accepted as socially adequate. Such residual risks can be referred to as the occurrence of statistically unlikely events or a tendency to damage that is not grasped by current knowledge and, therefore, not calculable. ${ }^{53}$ Nonetheless, the legislature is not prevented from granting a margin of appreciation (Beurteilungsspielraum) or leeway of discretion (Ermessen) to the administrative authority to ensure that the administration can deal with atypical, unforeseeable, or variable situations. ${ }^{54}$ Life circumstances are not entirely comprehensible and conceivable to the legislature. Due to the many peculiarities,

\footnotetext{
${ }^{52}$ Scherzberg, Wissen, Nichtwissen und Ungewissheit, in: Engel (ed.), Wissen, Nichtwissen, Unsicheres Wissen, 2002, p. 113.

53 Breuer, Gefahrenabwehr und Risikovorsorge im Atomrecht, DVBl 1978, p. 835.

${ }^{54}$ Detterbeck, Allgemeines Verwaltungsrecht (17th edition), 2019, p. 159 No 504.
} 
heterogeneities, and variations, they can often not be fully anticipated by the norm..$^{55}$

\subsubsection{Procedure and Subject Matter}

\subsection{Identification of the Facts and Prognosis of Damage.}

In the process of applying the law and making a decision of ex-ante intervention, after the ascertainment of the specific requirements of legal rules, the competent administrative authority is responsible for comprehensively investigating the facts of the case in accordance with the framework of the doctrinal constituent elements of facts. For example, the principle of official investigation is laid down in $\S 24$ of the Administrative Procedure Act (VwVfG) in Germany. It obliges the authority to ex officio investigate the facts relevant to the decision, i.e., to investigate the unique circumstances that characterize the individual case. ${ }^{56}$ The identification of individual facts is a synthesized conclusion of the peculiarity of social knowledge, the paradigm of organizing knowledge, and the reference standard for identification. Specifically, in the context of danger prevention, the steps for identifying the danger are to (1) collect the information on the factual situation, (2) and assess or predict the constituent factual elements of danger in an individual case, i.e., the extent of damage and the likelihood of occurring, according to the general reference standard, such as experience and common knowledge, which is organized by the structural causality paradigm and probability assumption.

The method of collecting information is diverse, even including the approach of a hearing procedure. After obtaining real-world information, the next step of the procedure for applying danger prevention known to lawyers, at least by name, is the prognosis. The competent authority has to make a prognosis with regard to the potential occurrence of damage that justifies its action. ${ }^{57}$ Whether the prognosis can lead to sufficient probability must be determined by a critical assessment, into which the amount of the expected damage

\footnotetext{
${ }^{55}$ Schmidt, Allgemeines Verwaltungsrecht (19th edition), 2016, p. 94, No 265.

${ }^{56}$ Wollenschläger, Wissensgenerierung im Verfahren, Tübingen 2009, p. 8-9; Appel, Staatliche Zukunfts- und Entwicklungsvorsorge, 2005, p. 146; Ladeur, Die Akzeptanz von Ungewissheit, in: Voigt (ed.), Recht als Instrument der Politik, p. 60 et seq.; Ladeur, Die Zukunft des Verwaltungsaktes, VerwArch Vol. 86 (1995), p. 517.

57 Thiel, Die "Entgrenzung” der Gefahrenabwehr, 2011, p. 65.
} 
is also incorporated. ${ }^{58}$ The assessment of probability is also necessary in the case of a subsequent "ex-ante" control, i.e., after a damage has occurred, based on knowledge at the time of the official action. As a rule of experience, the causality has to be assessed in predicting the occurrence of a particular result. The forecast of the probability of a loss occurring inevitably presupposes knowledge of the causal relationships and typical causal chains. Therefore, facts that have such a practical content are also called the forecasting element of facts or, in simplified terms, forecast facts. ${ }^{59}$ In other words, the meaning of assignments of tasks to the administration somehow amounts to inferring the damage. ${ }^{60}$ Suppose that the further course of a situation, including a possible occurrence of damage, is unknown. In that case, this is usually due to a lack of knowledge, the hypothetical existence of which would either result in a shift of the probability of occurrence into the realm of the legal concept of danger or would allow the probability of occurrence to "slide" into the realm of the practically impossible. ${ }^{61}$

The identification of a danger situation, as mentioned above, is a combination of the description of the individual factual situation and prediction of the near-future trajectory of an event occurring under both cognitive and normative perspectives based on a common rule of knowledge or empirical experience. Accordingly, knowledge, as well as experience, the cognitive paradigm organizing knowledge, and the consequential standard of reference for decision-making are of great significance for identifying danger situations before making an administrative decision on intervention since they construct the human cognitive activities.

3.2.3.2.2 The Subsumption of Individual Facts under the Norm and Margin of Appreciation

If the facts of the case are clarified, and the norm is interpreted, then the subsumption of

\footnotetext{
${ }^{58}$ Federal Administrative Court, BVerwGE 45, 51 et seq.; Scherzberg, Risiko als Rechtsproblem, VerwArch Vol 84 (1993), p. 484; Murswiek, Die staatliche Verantwortung für die Risiken der Technik, 1985, p. 85; Trute, Vorsorgestrukturen und Luftreinhalteplanung im Bundesimmissionsschutzgesetz, 1988, p. 16.

${ }^{59}$ Darnstädt, Gefahrenabwehr und Gefahrenvorsorge, 1983, p. 1.

${ }^{60}$ Darnstädt, Gefahrenabwehr und Gefahrenvorsorge, 1983, p. 25.

${ }^{61}$ Dreyer, Entscheidungen unter Ungewissheit im Jugendmedienschutz, 2018, p. 33.
} 
the individual facts under the constituent factual elements of the legal term normally is a relatively simple problem of appreciation. A threshold for the compulsive intervention of the authority exists when the extent of the damage and the probability of occurrence reaches a certain, normatively defined magnitude. When this normative threshold of danger is exceeded, protective measures are required regardless of the technical expenditure or the technical feasibility of such measures. The activity which triggers the danger must be prohibited entirely if necessary. ${ }^{62}$ In reaching a decision, it is necessary to observe a relation between the value of the goods (interests) at stake and the degree of probability: the higher the value of the goods, the less may the degree of probability be, and conversely, the lower the ranking of the threatened goods, the higher the degree of probability needs to be, which is also known as the principle of inverse proportionality. For this purpose, life ranks higher than the liberty of movement, human dignity higher than freedom of assembly.

However, the concretization of a norm is by no means so easy when the legislature uses an undefined concept, i.e., a broad statutory term. A broad statutory term as part of the constituent facts of the legal norm may denote a margin of appreciation (Beurteilungsspielraum) for the executive. The margin of appreciation refers to the freedom of concretization when the administration has to determine whether the individual facts of the case fall under the factual legal prerequisites for its actions. In reality, interpretation and subsumption are inseparably related to each other and intertwined, so that a free space necessarily must concern both addressed areas. Whether the administration possesses a margin of appreciation depends on the interpretation of the will of the legislature and some other conditions. It takes account of the complexity of the problem and the state of knowledge in the relevant field of law. Admittedly, a margin of appreciation of the executive is not recognized in the field of classic danger prevention; however, in order to ensure comprehensiveness of the decision-making framework and provide a preunderstanding for the following risk- decision-making mechanism, it can be stated that the exercise of a margin of appreciation operates in a similar way as the exercise of discretion which, in the German doctrine, only relates to the choice of legal consequences in response to assumed danger (see 3.2.2.2.3).

${ }^{62}$ Scherzberg, Risiko als Rechtsproblem, VerwArch Vol. 84 (1993), p. 484. 


\subsection{Determination and Substantiation of Legal Consequences}

Before the identified danger is materialized, according to the presupposed availability of an "average wealth of experience", the chain of events in the form of "cause -result" has to be interrupted by an antithetically determined preventive "measure," such as a police order to the perpetrator or a refusal of a permission applied for. ${ }^{63}$ The traditional security measures are coercion and command or prohibition, which directly affect individual freedom. Hence, the requirements of justification of state intervention must be fulfilled, and the premises of legal decisions are straightforward. ${ }^{64}$

The relevant legal consequence may be mandatory in the sense that the authority is bound to take a particular decision. The relevant law often empowers the authority to choose whether and how it reacts to the danger situation. This is called "discretion" (Ermessen). Art. 40 of the VwVfG in Germany stipulates that the exercise of discretion must be guided by the purpose of the authorization. The authority must, therefore, consider whether the realization of legal consequences, which may be chosen, would contradict the purpose of the standard or serve the purpose of the standard. The authority must also decide prospectively what consequences its exercise of discretion will have and whether these consequences correspond to the statutory purpose, i.e., the state desired by the legislature or considered desirable by the user of the law. ${ }^{65}$ Discretionary decisions are not to be conceived as selective decisions within a range of fluctuation determined by rational justifications but as the result of a process of designing, modeling, selecting, and revising provisionally useful decision alternatives. ${ }^{66}$

\subsection{Summary}

In traditional German theory, only a "danger" situation has legal relevance. Its connotation

\footnotetext{
${ }^{63}$ Ladeur, Das Umweltrecht der Wissensgesellschaft, 1995, p. 99-100.

${ }^{64}$ Alexy, Theorie der juristischen Argumentation, 1996, p. 17 et seq.

${ }^{65}$ Darnstädt, Gefahrenabwehr und Gefahrenvorsorge, 1983, p. 25.

${ }^{66}$ Scherzberg, Wissen, Nichtwissen und Ungewissheit im Recht, in: Engel (ed.), Wissen, Nichtwissen, Unsicheres Wissen, 2002, p.114 et seq.
} 
has two constituent elements: sufficient probability to occur and damage to the legitimate interest. In identifying danger, statistical probability and the extent of damage are assessed on the basis of "the average of experience" or "common knowledge", which provides a reasonably rational, evident, and practical standard to judge the legitimacy of ex-ante administrative intervention, thereby protecting individual rights.

The classic model of security and the legal institutions that follow it are based on a deterministic explanatory model of the world and a view of time as something linearly progressing ${ }^{67}$. Within this model, dangers and responsibilities can be attributed individually through empirical investigation and consideration of empirical principles. Such an understanding of the law is rooted in ideas of the principle of recognizability, predictability, and unambiguity of all processes; it no longer sees time as a quantity since all processes are regarded as fundamentally repeatable. ${ }^{68}$ Danger prevention is a legal theory that regulates the ex-ante decision-making behavior of intervention in a danger situation that constitutes a deviation from the rule and threatens the "normality" of legally protected goods. The dangerous chain of events is to be interrupted before the danger limit is exceeded by an antithetically determined "measure" (police order to the perpetrator). ${ }^{69}$ The danger prevention model and the security conveys are fundamentally based on the recognition of the causality between the present and future damaging events in a determined, reliably predictable, stable, and fundamentally reversible order. By linking the temporal dimension with the principle of causality, a feeling of security is conveyed that one is involved in a defined sequence of events. ${ }^{70}$

\footnotetext{
${ }^{67}$ Preuß, Risikovorsorge als Staatsaufgabe, in: Grimm (ed.), Staatsaufgaben, 1996, p. 533 et seq.

${ }^{68}$ Wahl \& Appel, Prävention und Vorsorge: Von der Staatsaufgabe zur rechtlichen Ausgestaltung, in: Wahl \& Appel (eds.), Prävention und Vorsorge, 1995, p. 29.

${ }^{69}$ Ladeur, Das Umweltrecht der Wissensgesellschaft, 1995, p. 101.

${ }^{70}$ Wahl \& Appel, Prävention und Vorsorge: Von der Staatsaufgabe zur rechtlichen Ausgestaltung, in: Wahl \& Appel (eds.), Prävention und Vorsorge, 1995, p. 29.
} 
4 The Challenges to the Conventional Decision-making Mechanism Associated with Uncertain Risk

Chasing for opportunities out of risk prevails in the risk society. The danger prevention system has been constructed to act as a crucial legal regime balancing public security and freedom. Uncertain risk has not been a legal issue in the first place. As uncertain risks gradually increased and became significant, they triggered social and legal concerns about it. As mentioned in the introduction, conflicts about the regulation of uncertain risks presented by biotechnology have confirmed that dealing with technology-based risks has become one of the central social issues. Since the influences of modern risks are characterized by their wide-ranging, uncertain, hi-tech, and value-concerned character, the state is under a challenge to take ex-ante measures to deal with the modern technological risks. ${ }^{1}$ However, identifying the danger in danger prevention neglects possible uncertainty deficits in the forecast of possible losses and thus conceals the possibility of a misjudgment; ${ }^{2}$ therefore, the existing legal regime of danger prevention and its administrative decision-making mechanism has been fundamentally destabilized under the backdrop of the increase of uncertain technological risks. In order to investigate whether there is a possibility of reformulating the administrative risk decision-making mechanism, two questions need to be analyzed: why uncertain risk becomes the expanded legal task of ex-ante intervention (section 4.1) and which legal challenges are posed by uncertain risk (section 4.2).

Overall, in the context of risk society, knowledge for decision-making is intricate, not easily accessible, or stable due to the risk with the character of high dynamic, uncertain, and hightech. The causal relationships cannot be ipso jure determined. Therefore, in the absence of objective, stable, and easily accessible decision-making reference standards as the basis of factual rationality, the legislature is unable to identify and weigh the conflicting interests,

\footnotetext{
${ }^{1}$ Ipsen, Die Bewältigung der wissenschaftlichen und technischen Entwicklungen durch das Verwaltungsrecht, VVDStRL 48 (1990), 177, 178.

2 Scherzberg, Risikosteuerung durch Verwaltungsrecht: Ermöglichung oder Begrenzung von Innovationen?, VVDStRL Vol. 63 (2004), p. 220; Spiecker genannt Döhmann, Uncertainty in EU Technology Regulation: How law making and law enforcing matters, in: Weimer, Cseres \& Eckes (eds.), The Rule of Law in the Technological Age: Challenges and Opportunities for the EU, Collected papers ACELG 6th Annual Conference, 2017, p. 38.
} 
set a pattern of behavior, assign a duty of care, precisely set the threshold of executive intervention to ensure the normative legitimacy of the executive's ex-ante intervention and ex-post attribution of action. The administration, which suffers from a lack- of factual rationality, also faces serious legitimacy problems in its ex-ante intervention decisions as there is no sufficient guidance by legislation. Leaving aside the issue of matter-of-fact rationality of decision-making, suppose that the legislature and administration would follow the traditional causality paradigm, which assumes the correctness of the knowledge possessed at the moment, and find a causal relationship between an activity and its potential consequences. And then, based on assumed causality, they would set rules of conduct using a case-by-case trial-and-error approach to updating the law. In that case, the law and administrative decision is likely to be quickly falsified by rapidly evolving technological discoveries, thus shaking its stability and possibly causing secondary institutional damage. ${ }^{3}$ The cost of "trial and error" in the new era of risk is often too much for society and individuals to bear.

\subsection{The Expanded Legal Task of ex-ante Intervention in Risk}

While modern society's evolution and the improvement of numerous human life domains are primarily based on technology and science innovation, excessive risks to humans and the environment are also caused by technology. ${ }^{4}$ Technological innovations are crucial drivers of economic, social, and environmental progress. ${ }^{5}$ However, the uncertain risks cause more and more security problems. Therefore, the state is obliged to protect society from unintended consequences while, at the same time, promoting the advancement of technology. On the one hand, the state is duty-bound to improve the public interest and ensure people's fundamental wellbeing by protecting individual freedom. It has no choice

\footnotetext{
${ }^{3}$ Scherzberg, Risikosteuerung durch Verwaltungsrecht: Ermöglichung oder Begrenzung von Innovationen?, VVDStRL Vol. 63 (2004), p. 219.

${ }^{4}$ Weimer \& Marin, The Role of Law in Managing the Tension between Risk and Innovation: Introduction to the Special Issue on Regulating New and Emerging Technologies, European Journal of Risk Regulation Vol.7: 03 (2016), p. 469.

${ }^{5}$ Innovation and progress are mirroring concepts. See Beck, Risk Society: Towards a New Modernity, 1992, p. 200, according to whom progress is an institutionalized extra-parliamentary structure of action for the permanent changing of society; Weimer \& Marin, The Role of Law in Managing the Tension between Risk and Innovation: Introduction to the Special Issue on Regulating New and Emerging Technologies, European Journal of Risk Regulation Vol.7: 03 (2016), p. 469.
} 
but to promote the advancement of science and technology to enhance productivity. On the other hand, as uncertain risks arising from technology continue to threaten public safety, the state is obliged to fulfill its security obligations. Calliess indicates, "it is a matter of providing the infrastructural inputs for economic growth and covering its external followup costs, such as environmental pollution.......". ${ }^{6}$ While the state has an obligation to guarantee the order and security of society, responding to risks and maintaining security gradually falls into the realm of law.

Because the potential impacts of risk are so broad, ex-ante interventions are socially more desirable than ex-post remedies. However, traditional ex-ante intervention tasks are limited to the danger range, so that the ex-ante task of the law has to be expanded in response to the complexity, uncertainty, and high-tech nature of modern risks. ${ }^{7}$ At the same time, the danger prevention system, which is centered on the balance of safety and freedom established through the doctrinal concept of danger, is subject to a series of challenges caused by uncertain risk. In the German context, risk precaution has been incorporated into the regulatory system as the strategic social concept responding to the challenge of uncertain risk to public security since the 1970s. ${ }^{8}$ Besides, risk has become the independent object of legal regulation. Not all risks can be subjected to the same legal regime. Consequently, the risk concept must be clarified to show what the regulatory regime looks like in the respective areas. There has been much scholarly discussion and judicial opinion against what kinds of risks the law should intervene precisely. This issue is generally discussed in conjunction with the precautionary reasons (Vorsorgeanlass) under Germany's precautionary principle. German law is characterized by the recognition and fundamental legal standardization of precaution. It opens the legal regulation to encapsulate risk beyond the danger already known from experience. ${ }^{9}$ Precautionary measures make it possible to apply the law and take precautionary measures, even if there is uncertainty and the facts of the case are not (fully) known. ${ }^{10}$

\footnotetext{
${ }^{6}$ Calliess, Rechtsstaat und Umweltstaat, 2001, p. 4.

${ }^{7}$ Karthaus, Risikomanagement durch ordnungsrechtliche Steuerung, 2001, p. 58.

${ }^{8}$ Huber, Risk decisions in German constitutional and administrative law, in: Woodman \& Klippel (eds), Risk and the Law, 2009, p. 21.

${ }^{9}$ Köck, Grundzüge des Risikomanagements im Umweltrecht, in: Bora (ed.), Rechtliches Risikomanagement, 1999, p. 151 et seq.

10 Appel, Bedeutung außerrechtlicher Wissensbestände für das Management von Unsicherheit, in: Hill \& Schliesky (eds.), Management von Unsicherheit und Nichtwissen, 2016, p. 116-120.
} 
Limitations on the precautionary reasons are intended to ensure the legitimacy of the State's precautionary measures and to prevent excessive and limitless interference with individual freedoms in the name of public security. Regarding the scope of risks that the law can intervene in, the predominant view in Germany is that the reason for initiating a precautionary measure is the situation of "concrete suspicion of danger" (konkreter Gefahrenverdacht) among the risks. ${ }^{11}$ This requirement can be understood as that when a preliminary, objective scientific risk assessment renders reasonable grounds for fearing that legitimate interests are sufficiently threatened, even if the scientific evidence is insufficient, inconclusive, or ambiguous, the State may decide whether measures are required and if this is affirmed take precautionary measures commensurate with the risk. A possibility of harm that is "at least realistic, or conceivable based on empirical evidence", in the light of scientific evidence, notwithstanding uncertainties, is a ground for opening the precautionary principle. ${ }^{12}$ What distinguishes a "concrete suspicion of danger" from conventional danger is that the former lacks the "certainty" and the temporal "realistic urgency" that danger requires. Thus, the rationale for precaution has a dual character. On the one hand, there is a problem with uncertainty as to the extent and occurring possibility of harmful effects on the legitimate interests and, on the other hand, there is a problem whether the suspected risk may, with sufficient probability, cross the threshold of danger in the future. ${ }^{13}$

However, this theory of "concrete suspicion of danger" has been criticized by some scholars. First, by limiting areas of "concrete suspicion of danger," precautionary measures cannot be

\footnotetext{
${ }^{11}$ Wahl \& Appel, Prävention und Vorsorge: Von der Staatsaufgabe zur rechtlichen Ausgestaltung, in: Wahl \& Appel (eds.), Prävention und Vorsorge, 1995, p. 126 et seq.; Calliess, Rechtsstaat und Umweltstaat, 2001, p. 210, 223 et seq.; Scherzberg, Risikoabschätzung unter Ungewissheit, ZUR Vol. 6 (2010), p. 303; Rehbinder, Ziele, Grundsätze, Strategien und Instrumente, in: Rehbinder \& Schink (eds.), Grundzüge des Umweltrechts (5th edition), 2018, p. 179.

12 Ossenbühl, Vorsorge als Rechtsprinzip im Gesundheits-, Arbeits- und Umweltschutz, NVwZ 1986, p. 166 et seq.; Ladeur, Das Umweltrecht der Wissensgesellschaft, 1995, p. 164; Christian Calliess, Rechtsstaat und Umweltstaat, 2001, p. 209.

${ }^{13}$ Rengeling, Die immissionsschutzrechtliche Vorsorge, 1982, p. 64 et seq.; Reich, Gefahr-Risiko-Restrisiko, 1989, p. 195 et seq.; Ladeur, Das Umweltrecht der Wissensgesellschaft, 1995, p. 99 et seq.; Scherzberg, Risiko als Rechtsproblem, VerwArch Vol. 84 (1993), p. 484; Köck, Risikovorsorge als Staatsaufgabe, AöR Vol. 121 (1996), p. 16.; Lübbe-Wolff, Präventiver Umweltschutz, in: Bizer, Johann (ed.), Sicherheit, Vielfalt, Solidarität, 1998, p.47.
} 
applied to risks of unknown magnitude and distance risks. ${ }^{14}$ Secondly, this limitation may reduce the time for State intervention in case of future harm. Danger prevention is primarily oriented at protecting existing interests, and risk precaution must cover the protection of future interests. ${ }^{15}$ The very functional orientation of the risk precaution principle is to advance the point of state intervention in the risk situation, thus preventing the realization of irreversible harm. If the limits of risk precaution are set to a "concrete suspicion of danger," the precautionary principle is overly constrained.

Risk precaution is the term used to describe the "advance transfer of danger prevention". ${ }^{16}$ It carries some innovative requirements for the law, but how it merges with the traditional ex-ante preventive model, i.e., danger prevention, necessitates a further analysis of the challenges that risk precaution poses to the law. However, it is not easy to distinguish between danger prevention and risk precaution in reality. ${ }^{17}$

\subsection{The Challenge to the Conventional Decision-making Mechanism}

Modern uncertain technological risk is not like conventional risk anymore because it is not just the result of actions but also the synthesis effects "of social and cognitive processes," which are full of uncertain elements beyond the current human's expectation and predictive ability..$^{18}$ Despite that understanding, the description of risk is much more than simply avoiding and regulating risks. It involves the social, spatial, and temporal distribution of the costs of risks and risk avoidance. ${ }^{19}$ Therefore, a precise diagnosis of the challenge posed by uncertain risk to the conventional legal administrative decision-making mechanism is the critical prerequisite for managing risk.

\footnotetext{
${ }^{14}$ Rehbinder, Ziele, Grundsätze, Strategien und Instrumente, in: Rehbinder \& Schink (eds.), Grundzüge des Umweltrechts (5th edition), 2018, p.179; Wahl \& Appel, Prävention und Vorsorge: Von der Staatsaufgabe zur rechtlichen Ausgestaltung, in: Wahl \& Appel (eds.), Prävention und Vorsorge, 1995, p. 75; Calliess, Rechtsstaat und Umweltstaat, 2001, p. 207.

${ }^{15}$ Calliess, Rechtsstaat und Umweltstaat, 2001, p. 167.

${ }^{16}$ Stoll, Sicherheit als Aufgabe von Staat und Gesellschaft, 2003, p. 322.

${ }^{17}$ Silveira Marques, Der Rechtsstaat der Risikovorsorge, 2018, p. 136.

${ }^{18}$ Lepsius, Risikosteuerung durch Verwaltungsrecht: Ermöglichung oder Begrenzung von Innovationen?, VVDStRL Vol. 63 (2004), p. 264.

${ }^{19}$ Calliess, Rechtsstaat und Umweltstaat, p. 161.
} 
If the characteristics of risk, such as the possible damage caused by the realization of the risk being significant or irreversible, and manufactured by humans, are the basis of the obligation of law to manage risk, other characteristics of risk, such as uncertainty and its high-technological nature, shake the legitimacy of law in effectively managing risk because risk poses many challenges to traditional law. The uncertain risk inherently affects the operation of the cognitive rule of the legal system, i.e., it is associated with a lack of reliable, relatively stable, assessable knowledge and experience with the rule of regularity for predicting damages. Due to the complexity and uncertainty of the cause-and-effect relationship, the legislature has difficulty in identifying the conflicting interests and will be more afraid to make value assessments, allocate duties of care and set up unified and straightforward "points of intervention" by the authorities; thus, a grant of a margin of appreciation to the administrative authority is a normal response. Response to modern uncertain risk suffers from a lack of cognitive rules and normative rules in decision-making by administrative agencies (Section 4.2.1). While deciding on ex-ante intervention, the technological risk directly affects the basis of empirical knowledge, which leads to the consequence that the administrative authority lacks reference standards for identifying the factual "risk", while it possesses a margin of appreciation but less control in subsuming the factual "risk" under the relevant norm. Thus, the rationality and legitimacy of administrative decisions are in doubt. Accordingly, the equilibrium between security and freedom is also in crisis as there are no relatively unified and straightforward "points of intervention" of the authorities (4.2.2 and 4.2.3).

\subsubsection{The Dilemma of Generating the Cognitive Reference Standard}

As mentioned above, one of the central challenges of public law exists in that empirical knowledge about the factual consequences and normative prerequisites for in decisionmaking on interventions in constellations of uncertain risk is no longer readily available.

\subsubsection{Relative Dynamics of Risk Knowledge}

In the risk society, as the field of human scientific and hormonal exploration continues to 
expand quickly, so does the field of cognition. The new uncertain risk increases with the emergence of new materials and technology. As regards new materials or new technologies, human beings have mastered certain regularity, such as the economic benefits of GM technology, but have not yet fully grasped the causal chains, especially about uncertain risks, such as possible damage caused by GMOs. Therefore, these pieces of knowledge and experience are the risk-knowledge interface between chaos and order. In contrast to hierarchical knowledge organized by the causality paradigm, risk-knowledge with stochastic variation is dynamic, non-linear (intricated), fragmented, and expanding. The causal chain between events is unclear and static but frequently crosses the original "causeeffect" trajectory. There neither is a vis-a-vis correspondence (as the relationship under the causality paradigm) nor a specific range of correspondence (as the relationship under the probability paradigm). Instead, one cause may produce many results, and one effect may be caused by many reasons. The uncertainty is mainly produced by human behavior, especially by high technology.

Chaos can no longer be fundamentally separated from the order and declared as an uncontrollable coincidence being a residual quantity that eludes human domination by forming order. ${ }^{20}$ The boundaries between order and chaos always remain unstable, both in nature and society, since both are bound. The newly discovered causal chains with the appearance of dynamic, non-linear (intricated), and uncertain (stochastic) properties can no longer be simply decomposed into individual events with regular cause-effect relationships; thus, the stable frame of scientific reference for thought on social decisionmaking has also been called into question. When the knowledge system, due to the integration of new stochastic variations, becomes an unstructured pool, the non-linear, imbalanced problems caused must be dealt with to restore its orientation function for social activities and preserve social stability and people's expectations of behavior.

\subsubsection{Partial Failure of the Causal Paradigm in Organizing Risk-related Knowledge}

Based on the observation of the causal link in the sense of a natural rule, the rule of causality

${ }^{20}$ Ladeur, Das Umweltrecht der Wissensgesellschaft, 1995, p. 79. 
is established by the causal paradigm, which formulates distinctions and unique "events" by confining the causal chain. The perception of an objective, stable, and the straightforward natural causal link is fundamental to the practicality of the causal paradigm. The fact that uncertainty occurs in various variants weakens the structure-forming force of the causal paradigm to establish the rule of causality. When risk knowledge about the causal chain is characterized by always dynamics, non-linearity (intricated nature), and uncertainty (stochastic nature), the causality model proves to be too rigid for fulfilling this structuring service and holds too little complexity. Therefore, it can no longer assume the stability of the permanent graduation of "natural complexity levels."

Moreover, the dynamics and non-linearity (intricated nature) of risk also lead to the partial failure of the probability paradigm. Probability assumptions generally assume that the "canonized examples" are comprehensive, typical, and objective, and on this basis, establish the rule of causality and ignore individual variations, which are taken into account afterward by learning from the case of error. However, in the context of uncertain risk, there are s no "canonized examples", or they are difficult to set up for calculating the probability because the possible variations can no longer easily be regarded as a negligible variation of the known. For example, in the case of rare events (nuclear power plant accidents), it is no longer a question of estimating a relative frequency distribution based on previous experience but of forming a model assumption based on abstract knowledge independent of concrete cases. Besides, this development also limits the possibility of learning from error. Presupposed paradigms of knowledge organization (especially the probability model) could accept certain risks (disorder) contained therein as a conceptually incomprehensible "rest"; however, the potential damages from residual risk may be too great for society to bear them. Therefore, in the risk society, the established rule of causality (i.b.s.) can easily become invalid and inappropriate. However, causal thinking is indispensable for technology because it allows the attribution of responsibility by operating with a pragmatic stop rule ${ }^{21}$.

Since the weakening of the causality model, the establishment of the rule of causality can

\footnotetext{
${ }^{21}$ Rasmussen, Event Analysis and the Problem of Causality, in: Rasmussen (ed.), Distributed Decision Marking - Cognitive Models for Cooperative Work, 1991, p. 252.
} 
no longer be based on the simple observation of events and the generalization of their observable rules; instead, a new paradigm to hierarchical gradate "natural complexity levels" is necessitated. ${ }^{22}$. This can also be seen in the determination of the attributable course possibilities, which now have to be extended to diffuse contributions to complex damage events (such as forest damage ${ }^{23}$ or climate change damage). Other examples include diffuse negative synergisms in complex installations (which can contribute to incidents) that can (so far) not be causally linked to an action, or - if one considers the extension of the damage indicators to diffuse "legal assets" such as the natural balance ${ }^{24}$ - an individual contribution to a diffuse concentration of conditions that lead to changes in the natural balance that are difficult to describe and assess.

\subsubsection{The Deficits of Spontaneous Accumulation of Knowledge in Establishing the} Cognitive Reference Standard

Uncertain risk does not only imply a quantitative extension of the concept of danger to distant damage possibilities; it also loses its reference standard for decision-making. ${ }^{25}$ The traditional identification of the danger situation, such as in the approval of installations or substances, etc., has always presupposed the availability of an "average wealth of experience" as the direct reference standard of decision-making, which made it possible to draw conclusions about the future from past events, at least with regard to technical processes. Besides, the reference standard of the rule of causality is closely linked to relatively stable knowledge stocks, in which the causal chain is simple and bundled in stable development trajectories and their structural paradigms (causality, probability). As for the preliminary reference for identifying uncertain risk, there is no (sufficient) common knowledge or experience that could assume this role for identifying risk. Overall, previous knowledge and experience are generated in a slow process with a "trial-and-error" approach, which is a gradual and spontaneous accumulation process, and humans are passive recipients. The

\footnotetext{
${ }^{22}$ Rasmussen, Event Analysis and the Problem of Causality, in: Rasmussen (ed.), Distributed Decision Making Cognitive Models for Cooperative Work, 1991, p. 247 et seq.; Küppers (ed.), Ordnung aus dem Chaos, 1987, p. 1.

${ }^{23}$ Ladeur, Entschädigung für Waldsterben?, DÖV 1986, p. 445 et seq.

${ }^{24}$ Bavarian Administrative Court of Appeal, NuR 1980, p. 25; Federal Administrative Court, NuR 1989, p. 385.

${ }^{25}$ Krüger, Kausalität und Freiheit, Neue Hefte für Philosophie 1992, p. 1 et seq.
} 
nature of uncertain risk makes it difficult to establish a reference standard for decisionmaking. The rapid turnover of risk knowledge means that humans have to actively use the causal paradigm to organize knowledge and generate the rule of causality, i.e., regularity.

Firstly, the uncertainty (stochastic nature) and dynamics of risk knowledge make it difficult for the causal paradigm to be applied to the acquired knowledge of the time and to organize it as well as to form a stable rule of causality. Therefore, it is necessitated that the expectations of substantive stability shall be lowered. As mentioned before, common knowledge or experience plays a significant role in providing a practical regular rule for the prognosis of damage in a "danger" situation. Correspondingly, it forms an individual's expectation and a stable association in society. However, the rapid development of technology on ever new development trajectories hinders (or prevents) the maintenance of a common experience linked to a stable network of relationships. Due to the dynamics and complexity of knowledge, it is no longer possible to use the causality paradigm to select the "canonized examples" and calculate the probability and relevant damage. The experience and trial treatment of the actors involved in the development and stabilization of technology are overtaxed as bearers of practical knowledge in the face of a rapidly developing technology.

Secondly, the highly specialized and decentralized nature of risk knowledge, especially the involvement of multiple disciplines, makes it challenging to form common knowledge that can be widely grasped by the public, necessitating a dialogue between disciplines, between experts and the public. Due to the high-technological and diffused character of scientific knowledge, it is not like the common knowledge that can be aggregated spontaneously and grasped by the public. Knowledge and experience no longer spread continuously and gradually among the public. The new knowledge is distributed over big companies and not over a totality of individuals, such as personal experience, which increases the difficulty of testing knowledge and forming public knowledge. For example, a considerable part of the knowledge produced by the market participants is not subject to state observation and therefore poses significant problems for the reception in more complex decision-making processes. Each participant in the risk society knows only one fragment of the whole 
knowledge. ${ }^{26}$ No one is able to achieve a comprehensive examination of the relevant knowledge.

The formation of experience and knowledge formerly was a self-reinforcing process of selforganization and self-stabilization, but due to the increasing number of variations of the "canonized examples" and the dynamics generated by them, the development of experience and knowledge can no longer take place without systematic observation, control and distribution by official procedures. Even the permissible range of fluctuation of the supply of new knowledge of action through random variations can no longer be determined and limited by the spontaneous formation of social convention alone. ${ }^{27}$ Therefore, risk knowledge can now primarily be generated through explicit, systematic organization and no longer be formed implicitly by social conventions that allow expectations or by continuous aggregated experience ${ }^{28}$.

Thirdly, the high complexity and non-linearity (intricate nature) of risk knowledge means that risk knowledge is not connected linearly from point to point, and the rule of causality cannot be obtained through simple observation, which requires a new paradigm with more normative elements to assess and segment the complex causal chains. Science changes fundamentally in that it is no longer to supplement the formation of experience with expert knowledge but to replace it to a large extent under conditions of uncertainty. Due to the occurrence of diffuse causality and cross-linking effects that are difficult to describe, new ways of generating "common knowledge" are therefore needed. They can no longer be formed by market conventions that allow expectations or by continuous aggregated experience. ${ }^{29}$ Besides, risk knowledge cannot be taken over in an unprocessed shape into developing common knowledge and being used for administrative decision-making. ${ }^{30}$

Finally, the broad impact of uncertain risk has the consequence that the adoption of a "trial-

\footnotetext{
${ }^{26}$ Polanyi, The Tacit Dimension, 1966, p. 72 et seq.; Ladeur, Das Umweltrecht der Wissensgesellschaft, 1995, p. 33.

${ }^{27}$ Rasmussen, Event Analysis and the Problem of Causality, in: Rasmussen (ed.), Distributed Decision Marking

- Cognitive Models for Cooperative Work, 1991, p. 255.

${ }^{28}$ Ladeur, Das Umweltrecht der Wissensgesellschaft, 1995, p. 33.

${ }^{29}$ Ladeur, Das Umweltrecht der Wissensgesellschaft, 1995, p. 61.

${ }^{30}$ Ladeur, Das Umweltrecht der Wissensgesellschaft, 1995, p. 154-157.
} 
and-error" approach may result in significant irreversible damage, which necessitates more precautionary measures. Risk is not only a question of coping with a scientific problem but also a problem of the social institutionalization of confidence-building through the formulation of stop rules that enable action to be taken on the basis of incomplete knowledge. ${ }^{31}$ Since knowledge production by "learning from error" is shaken, proactive learning through modeling and testing of possibilities must be explicitly and systematically set up to enable collective learning and the aggregation of different types of "common knowledge" as a basis for the permanent generation of innovations.

\subsubsection{The Deficits of the Normative Rule}

There are two different legal uncertainty scenarios from the viewpoint of the interaction between law and technology ${ }^{32}$ : In the first place, the legislative and administrative approaches cannot rely on sufficient cognitive knowledge and are put into question because of uncertainties with regard to what damages are expected to happen. Due to the lack of objective reference standards for decision-making, the legislature cannot identify the affected interests relatively accurately, and as a consequence, there is no way to analyze the interests, assess them, and prioritize them, establish rules of conduct, and allocate duties of care on this basis. As a result, it is also difficult to establish specific criteria for ex-ante intervention by the executive authorities. In the second place, misjudgment of legal institutions as to whether and to what extent rules have to be followed may lead to negative side-effects. Suppose the legislature was to build on existing knowledge and establish legal rules. In that case, such legislative provisions could either curb the development of scientific research or allow technology to undermine public security. Such institutional risks will only exacerbate the problem of scientific and technological risks. Therefore, the "static" maxims of action and decision must be replaced by flexible and dynamic procedural maxims.

\footnotetext{
${ }^{31}$ Wynne, Risk and Social Learning, in: Krimsky \& Golding (eds.), 1992, p. 278 et seq.

${ }^{32}$ Spiecker gen. Döhmann, Uncertainty in EU Technology Regulation: How law making and law enforcing matters, in: Weimer, Cseres \& Eckes (eds.), The Rule of Law in the Technological Age: Challenges and Opportunities for the EU, Collected papers ACELG 6th Annual Conference, 2017, p. 38.

${ }^{33}$ Scherzberg, Risikosteuerung durch Verwaltungsrecht: Ermöglichung oder Begrenzung von Innovationen?, VVDStRL Vol. 63 (2004), p. 217.
} 


\subsubsection{Dilemmas in Procedure}

In the face of knowledge deficits and uncertain and fragmented knowledge, the typical inefficiency of classical legal ex-ante decision-making - danger prevention - causes many legal issues if the administrative authority addresses modern risks. It may fail to predict the facts of the individual case, and ultimately the presumed legal rationality may be shaken, etc.

4.2.3.1 Lack of Reliable Information in the Process of Identification and Prognosis of Damage

Procedurally, uncertainty affects the decision-making content on uncertain risk at first, i.e., influences the search for information and the prediction of risk. Considering the fundamental changes in the structure of social knowledge, it must be accepted that risk knowledge needed for the prognosis of risk can no longer be defined according to common knowledge. The authorities cannot make a prognosis because they lack the necessary information, even though there may be specific indications that a disturbance of public security and order may be caused. ${ }^{34}$ In contrast to a danger prognosis, which can be understood as a decision based on the premise that the extent of the uncertainty is reduced sufficiently much, ${ }^{35}$ risk prognosis or decisions under uncertainty lack the minimum qualifications for a probability assumption, the prognosis of the extent of damage or both. If risk precaution just follows the path of danger prevention by calculating the statistical probability of occurrence, it is inherently uncertain. The fundamental problem to overcome is precisely finding functional equivalents to "common knowledge" for the reference standard that coordinates action and enables the formation of stable expectations. Besides, it remains to be shown that one of the main problems in dealing with risk and uncertainty in the administrative procedure is the lack of a convention on the possibility of making a

\footnotetext{
${ }^{34}$ Huber, Risk decisions in German constitutional and administrative law, in: Woodman \& Klippel (eds), Risk and the Law, 2009, p. 21.

${ }^{35}$ Dreyer, Entscheidungen unter Ungewissheit im Jugendmedienschutz, 2018, p. 34 et seq.
} 
decision under conditions of uncertainty. ${ }^{36}$

4.2.3.2 Lack of Normative Standards in Subsumption: Extended Margin of Appreciation but Less Control

Under the classical model of decision-making on danger prevention, whether an identified factual danger or risk situation can be subsumed under the constituent elements of the relevant legal provision and initiating the ex-ante administrative intervention is justified by the legal provision, is a matter of the bounded application of a law unless the applicable law granted the administration a margin of appreciation. The applicable legal rules were supposed to explicate the "normal" state of the protected interests and corresponding danger situation falling under the scope of regulation, i.e., as an indicator of the necessity of risk intervention. However, due to the cognitive problems legislature encounters with respect to uncertain risks, it is unable to set out appropriate legislation in abstract-general form. Thereby the model of controlling the legitimacy of the administrative behavior through generally formulated legal rules is called into question.

Specifically, in the situation of uncertainty, the interests affected by the technology cannot be accurately identified, and the probability of occurrence of damage also cannot be calculated. If the extent of the expected disturbances and the probability of their occurrence cannot be anticipated or estimated on the basis of life experience, law and politics lack rational standards to formulate legal consequences. ${ }^{37}$ At most, the legislature can only formulate the general objectives of regulation in an abstract-general way, but not the means to be used or even the decision to be taken in the individual case. Despite that, the legislature may abstain from a measure temporarily or permanently but must then calculate the risks that this abstention entails for the conflicting legal interests. Both the approval and the prohibition of a risky technology are risky. ${ }^{38}$ Indeed, in order to provide the executive with flexible access to information, evaluation, and weighing up opportunities

\footnotetext{
${ }^{36}$ Norgaard, Coevolutionary Development Potential, Land Economics Vol. 60 (1984), p. 160.

37 Scherzberg, Wissen, Nichtwissen und Ungewissheit im Recht, in: Engel (ed.), Wissen, Nichtwissen, Unsicheres Wissen, 2002, p.114.

38 Scherzberg, Wissen, Nichtwissen und Ungewissheit im Recht, in: Engel (ed.), Wissen, Nichtwissen, Unsicheres Wissen, 2002, p.114.
} 
and risks, legislation may take the form of empowering the executive to determine what facts fall under a specific legal rule, for example, justify the conclusion of causation. However, such a margin of appreciation raises the problem of legislative restraint on executive legitimacy and judicial protection.

\subsubsection{Incapability to Make a Proportionate Decision}

The last step in making a risk decision is to determine ex-ante action to interrupt the risk situation, i.e., make the originator of the accountable cause assume responsibility through proactive administrative action. However, the uncertain risk is exceptionally dynamic, intricate, and uncertain, which also affects attribution. It is mainly a question of defining the "measures" in response to risk. Due to the dynamic, unclear, intricate causal relationships, the accountable "cause" to be interrupted, the "normal" state of the protected interests to be preserved, and the appropriate precautionary interrupting measure to be taken are difficult to identify; therefore, the application of "precautionary measures" also encounters problems.

Firstly, due to the complex social relationship, the rule of regularity is difficult to establish, so it is difficult to identify the accountable "cause". A damage may not be caused by one cause or one subject but rather be a compound effect. This is also reflected by the large dimension of time, within which "gradual damages" come to light. (This can also be observed in the special case of contaminated sites). This becomes problematic if the attribution of risk is de-individualized, i.e., the associated possibility of damage can no longer be limited to a limited scope and be attributed individually, but rather is of a collective character ${ }^{39}$ In any case, the uncertainty of the risk characterization also poses major problems for dimensioning the "defense" against risk because it cannot be obtained from the observation of a dangerous chain of events by designing an alternative, damageavoiding course of action. ${ }^{40}$

\footnotetext{
${ }^{39}$ Lepsius, Risikosteuerung durch Verwaltungsrecht: Ermöglichung oder Begrenzung von Innovationen?, VVDStRL Vol. 63 (2004), p. 264.

${ }^{40}$ Ladeur, Das Umweltrecht der Wissensgesellschaft, 1995, p. 102.
} 
Secondly, normality cannot be identified in an uncertain risk situation, as it may not be possible to clarify the affected interest in a short period of time. The traditional "necessity" of administrative preventive action for averting danger is designed to reinstate an original or normal state of the protected interests. ${ }^{41}$ What is or remains normality? ${ }^{42}$ Uncertainty not only makes it difficult to assess the actual impact on a legal asset on the basis of a normatively presupposed "normal stock" of legal assets, but this orientation problem also has an impact on the action side, since it is difficult to determine "points of intervention" without a relatively stable reference framework. ${ }^{43}$ Since there is no criterion of the "necessity" of administrative preventive action, precaution below the "danger threshold" can theoretically be extended as far as desired, consequently threatening the rule of law. ${ }^{44}$ There is hardly any practice that can provide orientation for precaution.

Thirdly, the side effects of precautionary interrupting measures may be uncertain. Unlike danger prevention, which does not present "side-effects" because it can use the legal interests recognized by the legal system as "endpoints" for the attribution of damage and has the objective guidance from the rule of causality, risk precaution may give rise to unexpected "side effects." The impossibility of stratifying "natural levels of complexity" and creating "canonized examples" makes it challenging to identify and assess the effects of "risk management." Therefore, the administration is confronting the problem of generating "negative synergisms" on the action side. Risk management must also take into account that the effects that a "decision" triggers in a network of relationships are not easily predictable. ${ }^{45}$ Ultimately, the risks of the risk society proved to be neither local nor time-limited. They could not be calculated according to the rules of causality, guilt, and liability, nor could they be compensated or secured. ${ }^{46}$

\footnotetext{
${ }^{41}$ Silveira Marques, Der Rechtsstaat der Risikovorsorge, 2018, p. 115.

42 Ladeur, Risikowissen und Risikoentscheidung, Kommentar zu Gotthard Beckmann, Kritische Vierteljahresschrift für Gesetzgebung und Rechtswissenschaft Vol. 74 (1991), p. 241.

${ }^{43}$ Ladeur, Das Umweltrecht der Wissensgesellschaft, 1995, p. 101-103

${ }^{44}$ On the problem of "proportionality" in risk decisions, Kloepfer, Umweltinformationen durch Unternehmen, $\mathrm{NuR}$ 1993, p. 243.

${ }^{45}$ Ladeur, Das Umweltrecht der Wissensgesellschaft, 1995, p. 110.

${ }^{46}$ Silveira Marques, Der Rechtsstaat der Risikovorsorge, 2018, p. 115.
} 


\subsubsection{The Affected Operating Principles}

\subsubsection{Rationality}

In order to avoid arbitrariness in view of the uncertainty and value-dependency of risk evaluation and to establish factual adequacy, the rule of law demands a "rational" risk decision in procedural and material respects according to traditional understanding. However, under the conditions of uncertainty, traditional expectations of rationality, which are linked to Max Weber's formula of "domination by calculation", ${ }^{47}$ cannot be fulfilled. The problem is that the rationality of a decision may only be identified afterward, not beforehand, and, thus, may give rise to substantial or irreversible damage. Rationality must, therefore, be redefined under conditions of uncertainty. The need for the continuous updating of risk knowledge is undisputed but not infinite since infinite search may lead to decisions that cannot be made in a limited period of time, hindering the development of technology. Under these circumstances, the law cannot be satisfied with the demand for the additional acquisition of knowledge but must accept and structure action as such under conditions of uncertainty. According to Scherzberg, to highlight the specificity of the requirements for decisions under uncertainty, one has to replace the traditional paradigm of rationality with the postulate of wise decision-making. ${ }^{48}$

\subsubsection{Rule of Law}

Against an uncertain risk background, some of the basic assumptions of the liberal model of the rule of law, which deals with the control context of state powers, must be reconsidered. This model reaches the limits of its control power. As mentioned at the beginning, uncertain risk is essentially a knowledge problem, which leads to measures of danger prevention that cannot ensure security. Although risk and danger are similar in structure, the conventional approach assumes that the risk area is "below the threshold," which at the same time means a lowering of the threshold for intervention measures taken

\footnotetext{
${ }^{47}$ Weber, Economy and society, 1956, p. 129 et seq.

48 Scherzberg, Strategien staatlicher Risikobewältigung, in: Hill \& Schliesky (eds.), Management von Unsicherheit und Nichtwissen, 2016, p. 56-57; Scherzberg, Über Klugheit und Rationalität, in: Scherzberg (ed.), Klugheit, 2008, p. 25 et seq.; Spiecker gen. Döhmann, Rechtliche Strategien und Vorgaben zur Bewertung von Nichtwissen, in: Hill \& Schliesky (eds.), Management von Unsicherheit und Nichtwissen, 2016, p. 90.
} 
by the state. Once the uncertain risk "below" the danger threshold is accepted as a reason for risk precaution, which amounts to an increase of the need for state action, "excessive demands on the state" and a "steering crisis of the law" may be the consequence. ${ }^{49}$ In other words, preventive intervention in risk situations (risk precaution) means that the empowerment of administrative ex-ante intervention in social relationships must be expanded beyond the relative specific doctrinal "danger" situation at hand. This has the potential of encroaching on the principle of civil freedom. Thereby, the state intervention in risk faces questions about its legitimacy and thus necessitates being justified. Besides, against uncertainty and a highly variable risk background, the legal regime's efficiency and effectiveness to regulate modern risk and state behavior for protection from it are in doubt. 50 Traditional law-making is often seen as both ineffective and not equipped to govern technological change. ${ }^{51}$

\subsubsection{Aims of value: Losing the Equilibrium between Security and Freedom}

Since a comprehensive acceptance of uncertainty is likely to damage public safety, uncertain risk below the level of danger has to be the object of regulation by law. In contrast, strict risk precaution in the shape of suppressing any risk and uncertainty, may, to a large extent, impede the possibility of scientific and technological innovation and the driving forces of social development. As a result, the most challenging problem for the legal system is how to avoid discouraging social innovation while protecting public security. The borderline concept "danger" functions as the equilibrium point between public security and freedom in the public law system. "The narrower the concept of danger", the less the "freedom of citizens affected by state intervention is restricted"52. A functional equivalent to "danger" must also be found to coordinate the administrative control of risk and technological innovation in risk law.

\footnotetext{
${ }^{49}$ Calliess, Rechtsstaat und Umweltstaat, 2001, p. 66.

${ }^{50}$ Mostly come from the socialist view. Hiller, Probleme prozeduraler Risikoregulierung, in: Bora (ed.), Rechtliches Risikomanagement, 1999, p. 29.

${ }^{51}$ Weimer \& Marin, The Role of Law in Managing the Tension between Risk and Innovation: Introduction to the Special Issue on Regulating New and Emerging Technologies, European Journal of Risk Regulation Vol.7 (2016), p. 469; Weimer, et al, The Rule of Law in the Technological Age Challenges and Opportunities for the EU Collected Papers. Amsterdam Centre for European Law and Governance Research Paper No. 2017-02.

${ }^{52}$ Calliess, Rechtsstaat und Umwelstaat, p. 155.
} 


\subsection{Summary}

The challenges of technological risks to the legal institution can be briefly summarized as follows: In risk societies, there have been significant changes in the way knowledge is generated and presented. For example, much of it is no longer available to individuals, leading to the result that existing cognitive rules - causality and probability paradigms cannot effectively organize this knowledge. Therefore, social cognition, and thus the ability to form expectations when making a decision, the security, and stability of society are under threat. The legal rules regulating human behavior, such as danger prevention which are designed to maintain the stability and security of society, should have stepped forward to regulate risk and achieve security. But this rule of conduct is also rooted in the characteristics of traditional knowledge that has been organized on the basis of traditional paradigms that change with the advent of uncertain risk so that the set of the relevant rules of conduct becomes ineffective. The failure of the conventional rule of legal decisionmaking is reflected in the inability to identify the risk, set up a threshold for administrative intervention, determine threatened interests, and figure out legitimate measures of intervention the executive can take. It should be emphasized here that it is not that the causal paradigm as a cognitive approach is failing, but rather that the lack of reliable knowledge makes it impossible to apply this approach and to formulate a regular, rational refinement of the cause-and-effect relationship.

From the cognitive perspective, risk poses significant problems for the dimensioning of the risk "measure" because this measure cannot be obtained from the observation of a dangerous chain of events by designing an alternative, damage-avoiding course of action. ${ }^{33}$ Since the causal link becomes so opaque, dynamic, and complex, no sound knowledge acts as the basis for decision-making on relevant action. From the normative perspective, there are many problems that need to be solved, such as a rule to harmonize the various conflicting evaluations of the risk, how to construct the knowledge paradigm and the stop rule, etc. Besides, risk precaution creates a legal dilemma. The considerations on the precautionary

${ }^{53}$ Ladeur, Das Umweltrecht der Wissensgesellschaft, 1995, p. 102. 
principle and its construction have shown that its connection to the concept of danger and, thus, to the causality model on the action side leads to new problems, i.e., secondary problems of legal behavior. In view of that, the question arises as to whether and to what extent material uncertainty in decision-making can be compensated for by the legal institutions and how the legal regulatory strategy can adapt to these complex problems.

In the case of lacking necessary decision-making knowledge, the administration has no choice but to either generate the relevant knowledge or accept the ignorance, thereby enabling decisions to be made even under conditions of uncertainty. Therefore, two available parallel approaches ${ }^{54}$ for dealing with knowledge deficits stand out: On the one hand, by generating new knowledge and assessing it to reduce uncertainty; on the other hand, by developing substantive and procedural arrangements that allow for assessing, communicating, evaluating, and weighing up affected factors and interests under uncertainty conditions and thus enabling rational decision-making despite uncertainty. ${ }^{55}$ The next chapter will analyze these possible paths.

\footnotetext{
54 These two strategies are not exhaustive, but the instruments currently used by the legislature to manage risk can all be traced back to one of the basic forms discussed here. Scherzberg, Strategien staatlicher Risikobewältigung, in: Hill \& Schliesky (eds.), Management von Unsicherheit und Nichtwissen, 2016, p. 57; Köck \& Kern, Rechtliche Strategien zur Strategien zur Bewältigung von Risiken im Stoffrechts, in: Perspektiven des Stoffrechts, UTR Vol. 114 (2012), p. 21.

55 Scherzberg, Strategien staatlicher Risikobewältigung, in: Hill \& Schliesky (eds.), Management von Unsicherheit und Nichtwissen, 2016, p. 57; Appel, Bedeutung außerrechtlicher Wissensbestände für das Management von Unsicherheit und Nichtwissen, in: Hill \& Schliesky (eds.), Management von Unsicherheit und Nichtwissen, 2016, p. 128.
} 
5 General Legal Response Pertaining to the Administrative Decision-making Mechanism on Risk

According to the traditional understanding, a "rational" administrative decision is required to avoid arbitrariness in procedural and material respects. ${ }^{1}$ The expected "rationality" is based on Max Weber's formula of "domination by calculation" of fact ${ }^{2}$, i.e., based on empirical factual knowledge. Regarding administrative decision-making on risk, there is no longer sufficient knowledge available to rely on. Therefore, some new tasks to deal with the absence of traditional rationality have been proposed. ${ }^{3}$ From the perspective of the tasks of dealing with uncertain risk, regulation on risk decision-making is supposed to facilitate, on the one hand, the continuous generation of knowledge concerning forecasting the probability of damage occurrence and its magnitude in order to minimize or eliminate uncertain risk; on the other hand, communicating diverging opinions, establishing orientations for risk assessment and coordination of interests and ultimately enabling decision-making under conditions of incomplete knowledge. Legal handling of uncertain risk has changed over time. So far, two phases can be distinguished: While in the first phase, risks were defined as a legal problem, the foundations of legal risk regulation were formed, and the legal peculiarities of a risk law were developed, in the second phase, the specific difficulties of dealing legally with uncertainty and ignorance came to the fore. ${ }^{4}$ Currently, scholars' attention is focusing on issues at the second stage.

To be specific, previous studies had elaborated that uncertain risk is neither merely an empty space nor can be understood quantitatively as the incompleteness of the knowledge needed for decision-making. However, the practical dynamics of the growth of risk knowledge generate a mixture of uncertainty and ignorance. In this respect, the most appealing intuitive countermeasure for making a decision is forming legal "leaning ability" for the generation of knowledge ${ }^{5}$ in order to respond to the deficit of rationality of material

\footnotetext{
1 Scherzberg, Strategien staatlicher Risikobewältigung, in: Hill \& Schliesky (eds.), Management von Unsicherheit und Nichtwissen, 2016, p. 34

${ }^{2}$ Weber, Economy and society (4 ${ }^{\text {th }}$ edition), 1956, p. 124 et seq.

${ }^{3}$ Scherzberg, Klugheit und Rationalität, in: Scherzberg (ed.), Klugheit, 2008, p. 25 et seq.

${ }^{4}$ Appel, Bedeutung außerrechtlicher Wissensbestände für das Management von Unsicherheit, in: Hill \& Schliesky (eds.), Management von Unsicherheit und Nichtwissen, 2016, p. 128.

${ }^{5}$ It is important to note here that, despite differentiation between knowledge, information or date, it is
} 
and procedural rules, such as de-materialization of legislation by recourse to external knowledge ("state of the art of technology," "state of the art of scientific knowledge", etc.), or a broader delegation of freedom of assessment to the administrative authority ${ }^{6}$. These measures are supposed to contribute to construct the cognitive foundations for making a relatively rational decision.

In addition, since technological development is an incredibly diverse phenomenon and the need for information is potentially infinite, compensating uncertainty by "more information" quickly reaches a limit, especially due to the temporal pressure and material cost. In order to enable decision-making under conditions of incomplete knowledge and form social expectations, a stop-rule needs to be institutionalized in the legal system. Moreover, while the produced available stock of knowledge as the basis for an informed decision on a given matter does not yet indicate which kind of risks or remaining uncertainties should be accepted, ${ }^{7}$ interest weighing criteria at the normative level is necessary in order to be able to evaluate, prioritize and balance the affected interests. Therefore, except for knowledge deficits, legal rules must include analytical and deliberative elements ${ }^{8}$ to solve these risk decision-making issues. In other words, except for compensating for the factual limitation of rationality by knowledge generation, the tasks of the administrative risk decision-making mechanism also include the following: breaking off the endless search for information with stop rules, processing the information, setting up a normative rule for reconciling conflicting interests and ensuring administrative legitimacy while making decisions within a period of limited time based on the accumulated information. Accordingly, two different approaches seem to be available for dealing with uncertain risks: firstly, formulating legal regimes to reduce the uncertainty by generating

\footnotetext{
appropriate and helpful for discussing uncertain risk, this dissertation does not distinguish them. For the distinction between them see: Seckelmann, Evaluation und Recht, 2018, p. 35; Spiecker gen. Döhmann, Rechtliche Strategien und Vorgaben zur Bewertung von Nichtwissen, in: Hill \& Schliesky (eds.), Management von Unsicherheit und Nichtwissen, 2016, p. 90.

${ }^{6}$ Di Fabio, Verwaltungsvorschriften als ausgeübte Beurteilungsermächtigung, DVB1 1992, p. 1338 et seq.; Wahl, Risikobewertung der Exekutive und richterliche Kontrolldichte, NVwZ 1991, p. 409 et seq.; Breuer, Die internationale. Orientierung von Umwelt- und Technikstandards im deutschen und europäischen Recht, UTR Vol. 9 (1989), p. 47 et seq.

7 Appel, Bedeutung außerrechtlicher Wissensbestände für das Management von Unsicherheit, in: Hill \& Schliesky (eds.), Management von Unsicherheit und Nichtwissen, 2016, p. 128.

8 Scherzberg, Strategien staatlicher Risikobewältigung, in: Hill \& Schliesky (eds.), Management von Unsicherheit und Nichtwissen, 2016, p. 34.
} 
new knowledge; secondly, developing arrangements for the rest of legal issues and thus enabling rational decision-making despite uncertainty.

From the perspective of measures to deal with risk, the specific legal measures encompass two categories, - substantive and procedural ones. Among them, reformulating procedures attracted a high level of attention, presumed to be a pivotal approach. Specifically, on the one hand, it facilitates the generation of knowledge to ensure innovation of technology as well as security; and on the other hand, it avails for guaranteeing the social expectation of certainty, the legality of the administrative decision, and motivating the reconciliation of contradicting interests and acceptability of final decision, etc. ${ }^{9}$ Of course, substantive measures are also essential, including the cognitive standards, i.e., the (reference) standards for risk assessment, and normative standards, such as value priorities, risk preferences, and the allocation of duties of care. The whole system of managing risk is called risk management (in the broad sense), including the precautionary idea, a systematic procedure, etc. ${ }^{10}$ However, because the relatively static general substantive criteria are difficult to adapt to technological development, risk management focuses on procedural measures to meet the need for the relative stability of expectations while increasing flexibility of knowledge for decision making.

In the risk management system relating to administrative risk decision-making, there are two primary partly interrelated strategies to manage the risk that are currently used by the legislature and discussed by legal scholars: ${ }^{11}$ knowledge generation and proceduralization. The following sections illustrate why these two principles are essential for the adaptation of law from danger to risk, what functional effects they produce, and present the specific regimes required to support their materialization as well as possible side effects (5.1). Furthermore, a theoretical level administrative decision-making mechanism on risk that integrates knowledge generation and procedural elements will be introduced (5.2).

\footnotetext{
${ }^{9}$ Ladeur, Das Umweltrecht der Wissensgesellschaft, 1995, p. 77.

${ }^{10}$ Ladeur, Das Umweltrecht der Wissensgesellschaft, 1995, p. 78.

${ }^{11}$ For more information, see, for example, Köck \& Kern, Rechtliche Strategien zur Strategien zur Bewältigung von Risiken im Stoffrechts, in: Perspektiven des Stoffrechts, UTR Vol. 114 (2012), p. 21; Appel, Bedeutung außerrechtlicher Wissenbestände für das Management von Unsicherheit und Nichtwissen, in: Hill \& Schliesky (eds.), Management von Unsicherheit und Nichtwissen, 2016, p. 128; Scherzberg, Strategien staatlicher Risikobewältigung, in: Hill \& Schliesky (eds.), Management von Unsicherheit und Nichtwissen, 2016, p. 34.
} 
5.1 Primary Perspectives Reformulating the Administrative Decision-making Mechanism

Knowledge generation and proceduralization are not mutually exclusive; instead, they intersect with each other and are elements of different perspectives.

Viewing risk management from task and measure perspective respectively

\begin{tabular}{|l|l|l|}
\hline & Substantive measure & Procedural measure \\
\hline Knowledge generation task & & \\
(identification, assessment of & & \\
risk) & Risk Management \\
Other legal tasks: & \\
Risk evaluation & \\
Risk distribution & & \\
etc. & & \\
\hline
\end{tabular}

From the point of view of the tasks to be accomplished in risk management, there are other legal issues parallel to knowledge generation, e.g., balancing diverging interests with regard to the benefits and risks; and from the point of view of the nature of the measures used in risk management, there are substantive norms as opposed to procedural norms. For administrative decision-making on risk, knowledge generation and proceduralization are both the primary approaches or elements to reformulate the legal regime from different perspectives. The task of knowledge generation entails not only substantive but also procedural measures. The focus of it is endeavoring to expand the boundaries of knowledge continually. It is intended to ensure a continuous adaptation of decisions under uncertainty and ignorance to the latest knowledge bases. ${ }^{12}$ In contrast, the strategy of proceduralization is an integrated instrument to facilitate knowledge generation and deal with other challenges, such as control of the legitimacy of the administrative decision. In other words, the proceduralization of law coordinates the identified needs of promoting knowledge generation and satisfying other legal tasks in the risk decision-making process.

\footnotetext{
${ }^{12}$ Schulte, How to Deal with Knowledge, Non-Knowledge and Uncertain Knowledge in Law, in: Engel (ed.), Wissen, Nichtwissen, Unsicheres Wissen, 2002, p. 351.
} 


\subsubsection{Generation of Knowledge}

Although the rapid turnover and expansion of knowledge with the development of technology has led to the causal paradigm, especially the probability paradigm, which cannot presume "canonized examples" and ensure the stability of human knowledge in a certain period of time, eventually, as human knowledge increases, human beings will detect the causal chains of the natural world and organize them with the causal paradigm. The objective natural world has its intrinsic laws, and human beings need to continually expand their cognition or knowledge in order to master the regularity, i.e., by the rule of causality. Uncertainty of risk does not fundamentally shake the validity of the causal paradigm, but only the need for people's expectations of stability established by it to be lowered. In other words, the root cause of uncertainty of risk is that humans do not have sufficient knowledge and have not yet grasped the rule of causality regarding new materials and technology. In discussing the legal handling of uncertainty and ignorance, it is widely acknowledged that a very promising countermeasure is knowledge generation. ${ }^{13}$ From a very simplistic viewpoint, knowledge generation suggests learning more to compensate for deficits of empirical knowledge while making a decision. ${ }^{14}$ Rather than passively applying accumulated experience or knowledge, it refers to the activity of generating knowledge. Therefore, the decision-maker shall endeavor to expand the boundaries of knowledge continually by acquiring the latest knowledge bases from different sources. The aim is to reduce blind spots in knowledge and eliminate or mitigate risks. ${ }^{15}$

\subsubsection{Necessity and Function of Generation of Knowledge}

Despite the growing interest in knowledge generation ${ }^{16}$ and information processing, these

\footnotetext{
${ }_{13}$ Appel, Bedeutung außerrechtliche Wissensbestände für das Management von Unsicherheit, in: Hill \& Schliesky (eds), Management von Unsicherheit und Nichtwissen, 2016, p. 128; Scherzberg, Strategien staatlicher Risikobewältigung, in: Hill \& Schliesky (eds.), Management von Unsicherheit und Nichtwissen, 2016, p. 57.

${ }^{14}$ Junk, Die Rolle des Verwaltungsverfahrens in Deutschland und England, 2012, p. 114.

${ }^{15}$ Appel, Bedeutung außerrechtlicher Wissensbestände für das Management von Unsicherheit, in: Hill \& Schliesky (eds.), Management von Unsicherheit und Nichtwissen, 2016, p. 128.

${ }^{16}$ Kaiser, Generierung und Transfer staatlichen Wissens im System des Verwaltungsrechts, DVBl (2007), p. 171; Wollenschläger, Wissensgenerierung im Verfahren, 2009, p. 6.
} 
activities do not have any novelty value. The conventional certainty-oriented learning ability of legislation on new knowledge was compatible with relatively stable knowledge with linear causality in the conventional industrial society. Even though this formula which is based on sound empirical knowledge, does not take sufficient account of rapid technological changes, it is not a problem to initiate legal reactions only after adequate experience has been accumulated from the new technology. Besides, while making an administrative decision, knowledge generation was regarded as an internal procedure of administrative decision-making and ignored by legal regulation. The reason was that, on the one hand, the rule of law that characterizes administrative law focused mainly on the final administrative action in the relationship between citizen and state, having less interest in the process of decision-making itself; on the other hand, there generally existed a uniform understanding of "common knowledge" to refer to for identification of the individual fact of a case. However, in the risk society, the quality of knowledge stocks to be processed undergoes profound changes. From the perspective of the nature of the risk problems, these fundamentally reflect the problem that human cognition temporally lags behind technology development. To make an inappropriate analogy, the link between order and recognized chaos brought about by technological development is similar to the interaction between economic development and environmental deterioration in the environmental Kuznets curve. However, humankind is still at a stage where simultaneous growth of order and chaos has not yet fully reached the turning point where knowledge transcends chaos.

Considering that a deficit of knowledge can destabilize the knowledge-oriented decisionmaking rule of human activity and hinder identifying the risk and selecting appropriate risk management measures in various ways ${ }^{17}$ and that legitimate interests are facing massive and irreversible challenges of damage, the executive branch must investigate more in generating knowledge and experience to deal with knowledge deficits while making a decision. ${ }^{18}$ Accordingly, the law must, as far as possible, create legal framework conditions for the administration to listen to the information outside of the legal system and prevent

\footnotetext{
17 Scherzberg, Strategien staatlicher Risikobewältigung, in: Hill \& Schliesky (eds.), Management von Unsicherheit und Nichtwissen, 2016, p. 40.

${ }^{18}$ Spiecker gen. Döhmann, Rechtliche Strategien und Vorgaben zur Bewertung von Nichtwissen, in: Hill \& Schliesky (eds.), Management von Unsicherheit und Nichtwissen, 2016, p. 100.
} 
deficiencies and restrictions in the generation and evaluation of knowledge. ${ }^{19}$ The competent authority must minimize the gap between technological development and safeguarding legal interests, such as third parties' fundamental rights, public security, etc., from the outset. ${ }^{20}$ In areas where the necessary decision-making knowledge is no longer readily available to the state, the quality of available knowledge and the need for its systematic generation are becoming decisive determinants of the legitimacy of state decision-making and, thus, a central theme of administrative law. ${ }^{21}$

Besides, due to the characteristics of high-tech and fragmented risk knowledge, the decision-maker needs to maintain an active attitude to generate knowledge and construct more operational procedures to promote the exchange processes between the various organizations and individuals and process the constantly growing technological complexity in a learning process. ${ }^{22}$ Only through an active learning process can knowledge with dynamic and fragmented nature, removed from an experience-centered context, be accumulated. ${ }^{23}$ Recent technological developments have highlighted the importance of knowledge-generating networks as a source of technological innovation. ${ }^{24}$ Besides the cognitive function, knowledge generation also holds a function in controlling administrative behavior by opening up "sources of learning" and providing information on processes to develop measures and programs further. ${ }^{25}$ Resourcing non-legal knowledge serves to make legal regulation and concrete decisions comprehensible and acceptable when the law itself cannot provide the necessary constructive work. ${ }^{26}$

\footnotetext{
${ }^{19}$ Appel, Bedeutung außerrechtlicher Wissensbestände für das Management von Unsicherheit, in: Hill \& Schliesky (eds.), Management von Unsicherheit und Nichtwissen, 2016, p. 143-146.

${ }^{20}$ Wahl \& Appel, Prävention und Vorsorge: Von der Staatsaufgabe zur rechtlichen Ausgestaltung, in: Wahl \& Appel (eds.), Prävention und Vorsorge, 1995, p. 31-49

${ }_{21}$ Eifert, Das Verwaltungsrecht zwischen klassischem dogmatischen Verständnis und steuerungswissenschaftlichem Ansatz, VVDStRL Vol. 67 (2008), p. 326 et seq.; Wollenschläger, Wissensgenerierung im Verfahren, 2009, p. 34.

22 Wahl \& Appel, Prävention und Vorsorge: Von der Staatsaufgabe zur rechtlichen Ausgestaltung, in: Wahl \& Appel (eds.), Prävention und Vorsorge, 1995, p. 28.

${ }^{23}$ Franzius, Modalitäten und Wirkungsfaktoren der Steuerung durch Recht, in: Hoffmann-Riem, SchmidtAßmann \& Voßkuhle (eds), Grundlagen des Verwaltungsrechts, Vol. I, 2006 § 4 No 97 et seq. ; Wollenschläger, Wissensgenerierung im Verfahren, 2009, p. 34.

${ }^{24}$ Ladeur, Das Umweltrecht der Wissensgesellschaft, 1995, p. 247.

${ }^{25}$ Seckelmann, Evaluation und Recht, 2018, p. 53-60.

${ }^{26}$ Appel, Bedeutung außerrechtlicher Wissensbestände für das Management von Unsicherheit, in: Hill \& Schliesky (eds.), Management von Unsicherheit und Nichtwissen, 2016, p. 143-146.
} 


\subsubsection{Subordinate Requirements}

In the risk society, the dynamics and complexity of knowledge destabilize the conventional knowledge foundation of legislation, affecting administrative decision-making. Accordingly, the question is how to close the knowledge gap. Given the characteristic features of risk knowledge, namely their non-linear, dynamic, and fragmented nature, three concrete approaches can be provided to produce knowledge: de-materialize the legislation, integrate multipartite participation in the decision-making process, and open procedure for updating the information. The following section will investigate how these three approaches contribute to knowledge generation.

\subsection{De-materialization of Legislation and Delegation to the Administration}

Since it is not yet possible to foresee the probability of damage occurring during the "current event," technology law cannot be satisfied with general formulas and labels for the relationship between law and technology ${ }^{27}$ and limit itself to step-by-step or retrospective learning. It must modify itself to be adaptive to the new environment. Suppose the legislature does not want to wait until sufficient experience with a new technology has been gained to deal with uncertain risk. In that case, it can only regain regulatory certainty and decision rationality by granting more power to the administrative authority to expand the available knowledge about the possible impacts on humans and the environment. ${ }^{28}$ As a result, a de-materialized norm ${ }^{29}$ must be formulated to construct the ability to learn, i.e., to generate knowledge. Dematerialization means that the legislature only formulates a relatively abstract rule that must be concretized by the subordinate regulation or administrative implementation. It opens the control requirements on administrative acts, delegates the decision-making power to the administrative authority, and offers the best opportunity to explore the untapped potential of the administrative process. ${ }^{30}$

\footnotetext{
${ }^{27}$ Kloepfer, Art. „Technik“, in: Kunst, et al (eds.), Evangelisches Staatslexikon (3rd edition), Vol. 2, 1987, p. 3587 et seq.; Wahl \& Appel, Prävention und Vorsorge: Von der Staatsaufgabe zur rechtlichen Ausgestaltung, in: Wahl \& Appel (eds.), Prävention und Vorsorge, 1995, p. 48.

28 Murswiek, Die Bewältigung der wissenschaftlichen und technischen Entwicklungen durch das Verwaltungsrecht, VVDStRL 48 (1990). p. 216 et seq. ; Wahl \& Appel, Prävention und Vorsorge: Von der Staatsaufgabe zur rechtlichen Ausgestaltung, in: Wahl \& Appel (eds.), Prävention und Vorsorge, 1995, p. 48. ${ }^{29}$ Wollenschläger, Wissensgenerierung im Verfahren, 2009, p. 34.

${ }^{30}$ Junk, Die Rolle des Verwaltungsverfahrens in Deutschland und England, 2012, p. 114.
} 
De-materialization of the legislation can be regarded as the primary precondition for knowledge generation because it opens up free spaces for the experimental administrative application of the law. The de-materialized norm can be interpreted as experimental legislation designed to legally respond to hypothetical, possibly severe risks at the beginning of using new technology. Due to the uncertainty factor inherent in technical safety law, a specific experimental character of technical regulations is inevitable. The regulation may provide provisional and temporal measures corresponding to the specific areas where unlimited and obvious risks may or must be feared in a situation of uncertainty that cannot be resolved rapidly. ${ }^{31}$ It is only in this way that the complexities and processes of development and the management practices of modern administration can become more adaptive to technological development and produce more knowledge. ${ }^{32}$

Against the background of de-materializing the legal rule in response to uncertainty and recognized ignorance, the administrative authority should be entitled to a certain extended amount of margin of appreciation (Beurteilungsspialraum). ${ }^{33}$ According to the German Constitutional Court, regarding risks presented by nuclear energy, "only a continuous adaptation of the circumstances relevant for a risk assessment to the latest state of knowledge (...) can satisfy the principle of best possible danger prevention and risk precaution"34; in the opinion of the Court, the administration is better equipped for this than the parliamentary legislature. ${ }^{35}$ Therefore, the more uncertainty characterizes the risk situation, the more the requirement of knowledge generation needs to shift into a subsequent administrative observation, which is more flexible, timely, and adaptive. ${ }^{36}$ Generally, de-materialization, in conjunction with a delegation of power to the

\footnotetext{
${ }^{31}$ Wahl \& Appel, Prävention und Vorsorge: Von der Staatsaufgabe zur rechtlichen Ausgestaltung, in: Wahl \& Appel (eds.), Prävention und Vorsorge, 1995, p. 31-49.

32 Wahl \& Appel, Prävention und Vorsorge: Von der Staatsaufgabe zur rechtlichen Ausgestaltung, in: Wahl \& Appel (eds.), Prävention und Vorsorge, 1995, p. 31-49.

33 Appel, Bedeutung außerrechtlicher Wissensbestände für das Management von Unsicherheit, in: Hill \& Schliesky (eds.), Management von Unsicherheit und Nichtwissen, 2016, p. 116-120.

${ }^{34}$ Federal Constitutional Court, BVerfGE 49, 89 (139).

${ }^{35}$ Federal Constitutional Court, BVerfGE 49, 89 (139-40); to the same extent various decisions by the Federal Administrative Court; see: BVerwGE 72, 300 (314 et seq.); Delhey, Staatliche Risikoentscheidungen, 2014, p. 82.

${ }^{36}$ Reimer, Das Parlamentsgesetz als Steuerungsmittel und Kontrollmaßstab, in: Hoffmann-Riem, SchmidtAßmann \& Voßkuhle (eds.), Grundlagen des Verwaltungsrechts (2nd edition), Vol. 1, § 9, 2006, p. 578; Seckelmann, Evaluation und Recht, 2018, p. 48.
} 
administration, is reflected in the norm of "state of the art of the science and technology", designed as the cognitive rule or risk assessment standard. It aims to achieve the quickest possible incorporation of advanced knowledge of the factual bases of legal evaluation into the law. However, of particular note is that, unless there are clear statutory empowerments, the recognition of a margin of appreciation is very controversial. It has been accepted where statutory empowerments can be construed to the extent that the administration bears the primary responsibility for the relevant risk decision and shall have a margin of appreciation, especially where there are empowerments for generic concretization through ministerial regulations and administrative rules; this kind of argument may (but not necessarily will) also apply where individual decisions taken under the same law are at stake.

In other areas where there are no applicable rules to base an interpretation on, granting a margin of appreciation simply based on complexity and high scientific uncertainty becomes doubtful. A recent decision by the German Constitutional Court ${ }^{37}$ has introduced a new line of argument into the debate. According to the Court, "if there is a lack of generally accepted standards and methods for expert evaluation and the authority and the court reach the limits of their respective powers of knowledge," the authority is not required to resolve "the extra-legal actual knowledge deficit." 38 Under these circumstances, especially regarding the assessment of ecological risks, the administrative authority's plausible conclusions can be accepted by the judiciary without additional investigation and evaluation. According to the Court, where and as long as judicial control encounters objective limits, "administrative courts do not have to be wiser than administrative authorities in the domain of the natural sciences and technical matters." In brief, at the level of fact-finding and subsumption, normally only a special legal empowerment can confer to the administrative authority a margin (or prerogative) of appreciation. However, when the cognitive limit is reached, the court may be satisfied with only examining the plausibility of the assessment by the administrative authority instead of conducting a separate investigation and then make a judgment based on the administration's reliable conclusions. Of course, insofar as decisionmaking and interpretation latitude is recognized, the competent authority shall be

\footnotetext{
37 Federal Constitutional Court, BVerfGE 149, $407=$ NVwZ 2019, 52; see Eichberger, Gerichtliche Kontrolldichte, naturschutzfachliche Einschätzungsprärogative und Grenzen wissenschaftlicher Erkenntnis, NVwZ 2019, p. 1560.

${ }^{38}$ Federal Constitutional Court, BVerfGE 149, 407 = NVwZ 2019, 52, No 20.
} 
committed to the common good. ${ }^{39}$

\subsection{Multipartite Participation in Collecting Information}

Due to the characteristic features of risk knowledge - non-linear and fragmented - in a risk society, the concept of a relatively static form of knowledge generation under administrative law, undertaken unilaterally by the state, needs to be partially rejected. All necessary information for risk management in the administration cannot be obtained only by the administration itself, such as in the form of internal surveys or independent assessments. Since existing knowledge is not necessarily reliable because it is continuously changing as technology evolves and is not available for access by the state, it is inappropriate to rely unilaterally on the legislature or administrative agencies to provide the relevant knowledge. In order to investigate case information and generate knowledge, it is inevitable to include external professional knowledge in the practice of law ${ }^{40}$, and this depends on multipartite cooperation in the process of making the concrete administrative decision. Accordingly, the conventional forms of knowledge-generation that are mostly predetermined in a uniform way by the legislature in the relevant laws - have to be replaced by the organization of knowledge-generating communication processes. Only by designing the rules for participation as broadly as possible can the inadequacy of general knowledge be gradually compensated and a sufficient cognitive basis for administrative decisions be gained. ${ }^{41}$ It is no longer exclusively a matter of the participation of delimited groups of people who selectively expand the state's knowledge base, but rather the forum of communication must also open up to the general public. ${ }^{42}$

In general, the knowledge to be generated includes both professional and non-professional perspectives. The typical legal regime for including external knowledge to deal with uncertainty and recognized ignorance is in the form of consulting scientific and technical experts, the affected parties, and the public at large in the decision-making process. The

\footnotetext{
${ }^{39}$ Delhey, Staatliche Risikoentscheidungen, 2014, p. 78.

${ }^{40}$ Appel, Bedeutung außerrechtlicher Wissensbestände für das Management von Unsicherheit, in: Hill \& Schliesky (eds.), Management von Unsicherheit und Nichtwissen, 2016, p. 143-146.

${ }^{41}$ Wollenschläger, Wissensgenerierung im Verfahren, 2009, p. 35.

${ }^{42}$ Delhey, Staatliche Risikoentscheidungen, 2014, p. 111.
} 
participation of experts with specialized knowledge or background in the decision-making process and provision of professional advice is an old regime whose importance needs no further explanation. To address the complexity of the issues, special experts from various scientific disciplines are required. ${ }^{43}$ In addition to the experts appointed by the authority, external experts may be heard and statements made if necessary. Moreover, public authorities may not "rely on a dominant opinion" when making risk decisions but should "consider all reasonable scientific knowledge." ${ }^{44}$ Considering that other individuals or organizations operating in related fields, such as technology and business, may hold more advanced practical professional knowledge, it is essential to establish a regime, in the framework of the application procedures, also to incorporate them into the decisionmaking process and make them assist the administration in generating knowledge. Typically, large companies hold most of the scientific and technical information and intellectual property rights and are most aware of the possible risks presented by the technology in question. Therefore, legal incentive regimes must be created to observe risks themselves and provide the essential information to the administration. ${ }^{45}$ For instance, operators' and producers' obligations to submit prescribed information and risk assessments are commonly laid down by many technical and environmental laws. ${ }^{46}$

The use of external expertise is an essential component within a model of administrative knowledge generation. ${ }^{47}$ However, the procedural element of multipartite participation cannot be reduced to an expert model. The expert model is only a matter of a material enriching the administrative action by advancing scientification of decision making. The non-professional participant is beneficial: on the one hand, for obtaining the information held by the public, and on the other hand, for increasing public acceptance. Nonprofessional knowledge is mainly communicated to administrative decision-makers by representatives of the public or public participation procedures. The cognitive foundation of the administrative decision can often only be provided in a process-discursive manner.

\footnotetext{
${ }^{43}$ Jaeckel, Gefahrenabwehrrecht und Risikodogmatik, 2010, p. 221, 238-240; 261-265; Delhey, Staatliche Risikoentscheidungen, 2014, p. 110.

${ }^{44}$ Delhey, Staatliche Risikoentscheidungen, 2014, p. 111.

45 Ladeur, Das Umweltrecht der Wissensgesellschaft, 1995, p. 247.

${ }^{46}$ Wollenschläger, Wissensgenerierung im Verfahren, Tübingen 2009, p. 35; Scherzberg, Strategien staatlicher Risikobewältigung, in: Hill \& Schliesky (eds.), Management von Unsicherheit und Nichtwissen, 2016, p. 58.

${ }^{47}$ Wollenschläger, Wissensgenerierung im Verfahren, 2009, p. 17.
} 


\subsection{Open Procedure for Updating the Information}

In addition to the plurality of participants, an open decision-making process is essential to guarantee the generation of knowledge. In the face of complex balancing needs, multipolar legal relationships, and far-reaching consequences of risk, the legal system can no longer guarantee legal certainty for an indefinite period. Since the decision-maker acquires temporarily valid information at the time of making the risk decision, the knowledge is continuously further developing; thus, some open process must be put in place after the decision has been made to ensure that the decision maker's knowledge is made is updated. An open procedure means that the administrative decision must be monitored after it is implemented and is reversible according to the respective state of knowledge. The regular monitoring procedure is designed to address the issue of whether the results of a risk decision and the measures taken in response are valid over time and can be justified further or, instead, must be updated. ${ }^{48}$ Keeping alternatives and options open for the future after making a decision enables the decision-maker to update decisions to ensure conformity with the current state of knowledge and the most recent changes of circumstances, ${ }^{49}$ thus creating sufficient flexibility for dealing with unforeseen situations and the capability of legal systems to be adaptive to social complexity and generate more experience, thereby ensuring long-lasting security. This provides the greatest possible safeguards for consideration of all relevant interests.

\subsubsection{Secondary Problems Raised by Generation of Knowledge}

The requisite measures for knowledge generation are not perfect, and they inevitably are associated with some adverse side effects on the rule of law. The purpose of including these problems of knowledge generation in the analysis is to find ways to compensate for them subsequently.

\footnotetext{
${ }^{48}$ Appel, Bedeutung außerrechtlicher Wissensbestände für das Management von Unsicherheit, in: Hill \& Schliesky (eds.), Management von Unsicherheit und Nichtwissen, 2016, p. 116-120.

${ }^{49}$ Wahl \& Appel, Prävention und Vorsorge: Von der Staatsaufgabe zur rechtlichen Ausgestaltung, in: Wahl \& Appel (eds.), Prävention und Vorsorge, 1995, p. 31-49.
} 


\subsection{Legitimacy and Certainty Problems of the Administrative Decision}

The pursuit of knowledge generation through de-materialization of legislation and delegation to the administration has its price, which, to a considerable extent, is reflected in adverse effects on the expectation of certainty and the rule of law. First of all, appropriate standards for regulating administrative behavior regarding uncertain risk are challenging to develop due to the prevalence of uncertainty and the difficulty of access to (risk) knowledge. With their quasi-temporal, dynamic, and flexible characters, de-materialized norms often do not meet the normal deterministic criteria of substantive norms, which burden the law with elements of instability inherent in the concept of knowledge. Moreover, it causes the law to lose its role as a medium of control over administrative action and, accordingly, weakens the rule of law. ${ }^{50}$

The secondary problem caused by the de-materialization of legislation and delegation to the administration together with the openness of procedure may be that the pursuit of change, openness, and adaptability, to some extent, is too much in conflict with the predictability and certainty that law should achieve. ${ }^{51}$ Suppose that the law should not lose its role as a guarantor of the expectation of normative certainty. In that case, it must offset the secondary problems created by legislative de-materialization and delegation of the power to the administration by implementing stabilizing factors. In general, a shift to procedural control of legal decisions is preferable in order to allow flexibility in the generation and use of risk knowledge while leaving room for future alternatives, maintaining relative certainty, and controlling administrative decisions. This trend corresponds to the repeated demands in administrative law for a shift from a control function to a more constructive role that is more conducive to innovation and flexibility. ${ }^{52}$ In this interplay of opening through adaptation and restabilization through temporary consolidation, appropriate procedures are necessary as a significant step in dealing with

\footnotetext{
50 Seckelmann, Evaluation und Recht, 2018, p. 48.

${ }^{51}$ Wahl \& Appel, Prävention und Vorsorge: Von der Staatsaufgabe zur rechtlichen Ausgestaltung, in: Wahl \& Appel (eds.), Prävention und Vorsorge, 1995, p. 49-58.

52 Wahl \& Appel, Prävention und Vorsorge: Von der Staatsaufgabe zur rechtlichen Ausgestaltung, in: Wahl \& Appel (eds.), Prävention und Vorsorge, 1995, p. 31-49.
} 
complex knowledge structures. ${ }^{53}$

\subsection{Validity Problems of Generation of Knowledge}

The obligation to generate risk knowledge that can be used to make risk decisions ${ }^{54}$ also leads to new uncertainties, because here too, the problem arises that the amount of information potentially to be generated is infinite. The administration is also confronted with the problem of the generation of "negative synergisms" on the action side when deciding on the intensity of the advance of security through the systematic generation of risk knowledge: For example, if the testing requirements for new substances are significantly tightened, there is a likelihood that more use will be made of existing substances which, due to the complexity of the task, cannot all be subject to a notification procedure..$^{55}$

Arranging for the participation of multiple parties in gathering information has its drawbacks. Firstly, it is unclear how the law assesses and processes information from other disciplines in order to enable effective state action, on the one hand, but to guarantee the legitimacy of these decisions, which are influenced by authoritative expertise, on the other hand. In the relationship of law to external knowledge, there is also an imbalance in the attitude towards uncertainty: other disciplines do not (have to) find certainties over comparatively long periods of time or gradually give up certainties before they have been found; they can afford to live with these uncertainties, which may be long-term, and to a considerable extent undertake research on these uncertainties because uncertainties indicate to a certain extent the problems they can solve, thus driving the development of technology or science; in contrast, the law, the legislature, the administration, and the courts that must fulfill specific decision-making functions, cannot afford to live with uncertainties. ${ }^{56}$

\footnotetext{
53 Wollenschläger, Wissensgenerierung im Verfahren, 2009, p. 34.

${ }^{54}$ Lyndon, Risk Assessment, Risk Communication and Legitimacy: An Introduction to the Symposium, Columbia Journal of Environmental Law 1989, p. 291 et seq.

${ }^{55}$ Ladeur, Das Umweltrecht der Wissensgesellschaft, 1995, p. 110.

${ }^{56}$ Appel, Bedeutung außerrechtlicher Wissensbestände für das Management von Unsicherheit, in: Hill \& Schliesky (eds.), Management von Unsicherheit und Nichtwissen, 2016, p. 116-120.
} 
Secondly, more information does not guarantee better or more rational decisions in situations of uncertainty. ${ }^{57}$ Yet, it may increase the cost of the decision and the burden on the people involved, who are obliged to investigate. For example, when the risk assessments of new complex technologies include a plethora of unquantified or unspecified subjective expert assessments, these, as a result of mathematization and formalization, may create a false impression of accuracy. Besides, since administrative risk decisions are often highly complex, often requiring multiple experts from different disciplines and fields, companies, and the general public, it can be assumed that multipartite participation in the decisionmaking will be financially expensive and time-consuming. In addition, because of the requirements for effective safety control management, private operators may be obliged to report, document, and evaluate information over time, limiting their freedom to exercise a business and burdening economic activities. For instance, producers may be obliged to carry out specific test procedures with regard to the risk characteristics of new substances or update the information on existing substances and make the risk knowledge gained available to the administration. ${ }^{58}$ This may entail a considerable burden for the relevant operators.

\subsection{Stop Rule}

The generation of knowledge can play a crucial role in coping with uncertainty, but it is not omnipotent, especially not in situations with high levels of ignorance. Under conditions of high uncertain risk, new knowledge also generates new uncertainty. ${ }^{59}$ Moreover, the time for risk decisions is limited, but simultaneously, the knowledge required to achieve a high degree of certainty may be infinite. Therefore, an overemphasis on knowledge generation can reduce the efficiency of decision-making and may undermine innovators' freedom and motivation. In general, searching for information can be considered helpful in

\footnotetext{
${ }^{57}$ Spiecker gen. Döhmann, Rechtliche Strategien und Vorgaben zur Bewertung von Nichtwissen, in: Hill \& Schliesky (eds.), Management von Unsicherheit und Nichtwissen, 2016, p. 90.

${ }^{58}$ Ladeur, Das Umweltrecht der Wissensgesellschaft, 1995, p. 109.

59 Lyndon, Risk Assessment, Risk Communication and Legitimacy: An Introduction to the Symposium, Columbia Journal of Environmental Law 1989, p. 291 et seq.; Ladeur, Risikowissen und Risikoentscheidung, KriV 1991, p. 241 et seq.
} 
cases of quasi-safety and low levels of ignorance. In such cases, the expected benefits of searching for information can usually be well determined, and reliable conclusions can be drawn. The decision-maker can also determine what knowledge he lacks, how he can obtain it, and whether this knowledge will probably help reduce his uncertainty. ${ }^{60}$

However, under the pressure of time to make a choice, unilateral emphasis o endless searching and generating knowledge is absolutely unreasonable since it violates fundamental economic rights, such as the freedom of occupation, trade, property, and research..$^{61}$ Instead, the aim of structuring administrative decision-making must be to enable the state to act in good time and thus provide appropriate precautions for the future, especially under the conditions of the rule of law. ${ }^{62}$ Therefore, it is essential to know which rules guide the search for information ${ }^{63}$ and set up a stop rule to end an infinite search.

\subsubsection{Proceduralization}

There are only two kinds of legal instruments to regulate social relations and behavior: substantive and procedural rules. Proceduralization means that, instead of influencing the decision results by determining a concrete material control standard, the legislature mainly utilizes the procedure to regulate the related decision-making behavior by structuring the process and laying down the participants and their rights and responsibilities, etc. Proceduralization addresses the timing, structure, and content of a decision-making process. ${ }^{64}$ To a certain extent, procedural rules are expected to compensate for material control deficits of the administrative authority and facilitate decision-making. ${ }^{65}$

\footnotetext{
${ }^{60}$ Spiecker gen. Döhmann, Rechtliche Strategien und Vorgaben zur Bewertung von Nichtwissen, in: Hill \& Schliesky (eds.), Management von Unsicherheit und Nichtwissen, 2016, p. 100.

${ }^{61}$ Spiecker gen. Döhmann, Rechtliche Strategien und Vorgaben zur Bewertung von Nichtwissen, in: Hill \& Schliesky (eds.), Management von Unsicherheit und Nichtwissen, 2016, p. 102.

62 Scherzberg, Strategien staatlicher Risikobewältigung, in: Hill \& Schliesky (eds.), Management von Unsicherheit und Nichtwissen, 2016, p. 59.

${ }^{63}$ Spiecker gen. Döhmann, Rechtliche Strategien und Vorgaben zur Bewertung von Nichtwissen, in: Hill \& Schliesky (eds.), Management von Unsicherheit und Nichtwissen, 2016, p. 98.

${ }^{64}$ Junk, Die Rolle des Verwaltungsverfahrens in Deutschland und England, 2012, p. 67.

${ }^{65}$ Schulte, How to Deal with Knowledge, Non-Knowledge and Uncertain Knowledge in Law, in: Engel (ed.), Wissen, Nichtwissen, Unsicheres Wissen, 2002, p. 351.
} 


\subsubsection{Necessity and Function of Proceduralization}

The administrative procedure initially functions as an aid in the administrative implementing process, which only aims at "transporting" a solution that is shaped by substantive law. ${ }^{66}$ However, knowledge deficits and uncertain risk make it challenging to formulate clear material standards because they may prove to be highly vulnerable. ${ }^{67}$ Material law is facing the embarrassing situation that its cognitive foundation, knowledge, is uncertain, and may no longer exist at all in some cases. Since due to the very nature of uncertain risk, there cannot (yet) be any "truths" that could in themselves outline and justify every concrete decision as to the product of absolute decision-making standards, the idea of guaranteeing the "correctness" and legality of the decision by structuring the procedure is almost inevitable. ${ }^{68}$ Besides, as a formal concretization of the rule of law, the procedure can contribute to the reconciliation of interests between the state and its citizens and control the formal legitimacy of administrative behavior. Consequently, the procedure that constructs procedural rationality is evidently designed to grant more independence from the substantive rule instead of only playing an accessory role. Overall, the proceduralization of administrative decision-making mechanisms performs the following functions: assist with knowledge generation, promote the reconciliation of conflicting interests, compensate for material and legal deficits, control the legitimacy of administrative behavior, and enable decision-making respecting a stop-rule. ${ }^{69}$ The administrative procedure can be described as a place of development of a knowledge-generating, information processing, communicating, and decision-making process. ${ }^{70}$

\subsection{Generation of Knowledge and Stop Rule}

The uncertainty in risk decisions, arising from the current state of uncertain knowledge about the future at the time of making the decision, necessitates generating more knowledge so as to increase the rational basis of the decision and more accurately predict

\footnotetext{
${ }^{66}$ Junk, Die Rolle des Verwaltungsverfahrens in Deutschland und England, 2012, p. 110.

${ }^{67}$ Appel, Bedeutung außerrechtlicher Wissensbestände für das Management von Unsicherheit, in: Hill \& Schliesky (eds.), Management von Unsicherheit und Nichtwissen, 2016, p. 116-120.

${ }^{68}$ Luhmann, Legitimation durch Verfahren, 1969, p 203; Delhey, Staatliche Risikoentscheidungen, 2014, p. 162.

${ }^{69}$ Junk, Die Rolle des Verwaltungsverfahrens in Deutschland und England, 2012, p. 110.

${ }^{70}$ Gurlit, Eigenwert des Verfahrens im Verwaltungsrecht, VVDStRL Vol. 70 (2010), p. 231.
} 
its likely consequences. As discussed above in section 5.1.1, knowledge generation needs to be realized through multiple participation, which means that it establishes higher requirements for the administrative decision-making procedure. The aim is to ensure that administrative decision-makers seek advice from various experts and make a risk decision on this basis, in particular, in those areas of life that have not yet been scientifically researched to the extent that the consequences of taking the risk can be clearly predicted. Setting up a multipartite participation process bringing in the experts, as well as expert knowledge from affected parties and the public at large, and organizing a professional risk assessment process, is the only way to enable an interdisciplinary discourse that allows all sides to exchange and incorporate arguments. ${ }^{71}$ Moreover, the procedure of confining the decision-making period, in conjunction with the cognitive rule "state of the art" of science and technology, can effectively function as a "stop rule", enabling decisions to be made on the basis of limited knowledge. However, from a legal point of view, the incorporation of non-legal knowledge does not clarify how to make proper decisions. Therefore, substantive rules to assess such non-legal knowledge are still needed, which cannot be compensated by the procedure.

\subsection{Promotion of Reconciliation and Predictability}

Risk poses challenging tasks: knowledge generation and accepting the reality of limited knowledge and, on that basis, weighing conflicting interests, allocating duties of care for risk, and making risk decisions. In the midst of this, traditional coordination of interests tends to rely on relatively objective experience to predict adverse effects on the interests concerned, thus making it easier to balance the interests and set up a relatively stable and certain standard for administrative intervention. In contrast, the lack of a rational basis for predicting and coordinating interests makes it challenging to adopt legislation that primarily uses abstract-general rules and terms. Therefore, the regulatory function of the legal system for managing uncertain risk must rely more on concrete administrative decisions based on a case-by-case assessment. Despite that, in principle, it is possible for administrative decision-makers to balance interests alone after the affected interest have

${ }^{71}$ Delhey, Staatliche Risikoentscheidungen, 2014, p. 110. 
been identified; cooperative decision-making involving representatives of interests can lead to greater acceptance among the affected persons represented by them. ${ }^{72}$ It allows for direct dialogue between stakeholders and representatives of conflicting interests. This does not only lead to the disclosure of possible "emotional motivations", ${ }^{73}$ but also, and most importantly, allows for a direct exchange of views that at least compel them to take notice of each other directly. ${ }^{74}$ This may also reduce each individual decision-makers problems in the respective sub-section of the overall process in which he is empowered to make the relevant decision. ${ }^{75}$

Moreover, sometimes uncertain risks cannot be eliminated entirely but can only be dispersed over space and time. It is more advantageous to offer opportunities for the various affected subjects to participate in the decision-making process and express their views; this has a "confidence-building and expectation-stabilizing" effect. ${ }^{76}$ Besides, procedural clarification of requirements and procedures for the appointment of experts, as well as a transparent consultation process, are designed to ensure that, to the extent possible, nonlegal knowledge incorporated is neutral and reliable, and thus accepted and understood by decision-makers and the public.

\subsection{Compensation for Substantive Control}

The law as a medium of control not only steers the executive branch through its binding character based on a constitutional mandate but at the same time ensures stability. A prerequisite for this function is that the law is formulated in such a way that it binds the administration through concrete and complete instructions for its execution. Due to the factual uncertainty about whether or not the benefits pursued will be realized and/or

\footnotetext{
${ }^{72}$ Canenbley, Zweckmäßigkeit von Ausschüssen der Verwendung von Ausschüssen in der Verwaltung, 1968, p. 66; Dagtoglou, Kollegialorgane und Kollegialakte der Verwaltung, 1960, p. 51; Delhey, Staatliche Risikoentscheidungen, 2014, p. 110.

${ }^{73}$ Canenbley, Zweckmäßigkeit von Ausschüssen der Verwendung von Ausschüssen in der Verwaltung, 1968, p. 73; Sodan, Kollegiale Funktionsträger als Verfassungsproblem. Dargestellt unter besonderer Berücksichtigung der Kunststoffkommission des Bundesgesundheitsamtes und der Transparenzkommission, 1986, p. 56.

${ }^{74}$ Sodan, Kollegiale Funktionsträger als Verfassungsproblem. Dargestellt unter besonderer Berücksichtigung der Kunststoffkommission des Bundesgesundheitsamtes und der Transparenzkommission, 1986, p. 56.

${ }^{75}$ Appel, Bedeutung außerrechtlicher Wissensbestände für das Management von Unsicherheit, in: Hill \& Schliesky (eds.), Management von Unsicherheit und Nichtwissen, 2016, p. 116-120 .

${ }^{76}$ Delhey, Staatliche Risikoentscheidungen, 2014, p. 81.
} 
significant adverse effects will be caused, the factual and legal predetermination of administrative decision-making is only possible to a limited extent. The law is unable to set comprehensive regulatory standards for administrative decisions. As a result, the tasks of predicting, for example, whether there is sufficient probability or rather an uncertainty and assessing whether the risks outweigh the benefits or the benefits justify the risks ultimately becomes the responsibility of the competent administrative decision-maker.

Accordingly, the question of how to ensure the legitimacy of administrative risk decisionmaking relies more on procedural controls, such as public scrutiny and the procedure of public participation as well as judicial protection. When democratic legitimacy is difficult to achieve in the parliamentary process to control the legitimacy of administrative actions, this element of democratic legitimacy should be transferred to concrete administrative decisions. In the context of the level of democratic legitimation, making risk decisions with multipartite participation is a "communicative legitimation" that appears alongside the factual, personal, and functional-institutional modes of legitimation. ${ }^{77}$ Public participation in the administrative procedure can provide opportunities for balancing conflicting interests and create conditions for citizen control. Therefore, in administrative risk decision-making, there must be a process in which the public is given the opportunity to form and express their opinions, and the representatives of the people are encouraged to articulate in public debate their views about the necessity and scope of the measures to be taken. In addition to state control by the legislative and judicial branches, as well as by the executive branch itself, public control over risk management activities through public participation can continue to exist. ${ }^{78}$ Besides, transparent and formalized procedures, by means of an appropriate design of the decision-making procedure and an appropriate distribution of competencies, help control the administrative decision-making, thus compensating for the factual and substantive democratic legitimacy deficit. ${ }^{79}$ Through transparent procedures, such as information disclosure and public participation, the administrative process reconnects its decisions with the people; thus, it not only serves as a hinge between the administrative activity and the citizens but also as a link that provides

\footnotetext{
77 Scherzberg, Die Öffentlichkeit der Verwaltung, 2000, p. 293.

78 Arendt, Vita activa oder Vom tätigen Leben (8th edition), 2010, p .62.

${ }^{79}$ Delhey, Staatliche Risikoentscheidungen, 2014, p. 213.
} 
legitimacy. ${ }^{80}$

Another important aspect of the multifunctionality of administrative procedure undoubtedly is the order function ${ }^{81}$. Within the executive, the actual operations are assigned hierarchically, the coordination between different units is organized, and, in particular, the connection between the executive and the outside world, to the citizen, is formalized. In the process of this internal and external coordination, nodes of information processing ${ }^{82}$ that are of central importance for the aspect of knowledge generation become clear. ${ }^{83}$ The goal, the decision, becomes predictable or at least comprehensible in the procedure by structuring the decision-making process. ${ }^{84}$

\subsubsection{The Subordinate Requirements for Proceduralization}

The administration acts in accordance with procedural law, which serves to predefine decision results not by way of factual and content-related determination but by structuring procedures and conditions of decision making. Suppose that balancing public and private, sub-systemically aggregated and individual interests is shifted to the administrative procedure. In that case, this shift must be designed in such a way that the divergent social perspectives and interests of authorities, affected parties, and associations are taken into account in the construction of the problem area, the assessment of consequences, i.e., action, the compilation of the weighing material, and that a sufficiently complex decision design is developed that reflects the legal requirements of the social area to be regulated. The "correctness" of the decision is determined primarily by the design of the decision-making process. The corresponding specific procedural requirements need to be provided in addition, based on the possible functions of the procedure discussed above. The specific procedural requirements are described in section 5.2.2.

\footnotetext{
80 Junk, Die Rolle des Verwaltungsverfahrens in Deutschland und England, 2012, p. 67.

${ }^{81}$ Pünder, Verwaltungsverfahren, in: Erichsen \& Ehlers (eds) Allgemeines Verwaltungsrecht (13th edition), 2006, p, 365.

${ }^{82}$ Schmidt-Aßmann, Verwaltungsverfahren und Verwaltungskultur, NVwZ 2007, p. 40.

${ }^{83}$ Gurlit, Eigenwert des Verfahrens im Verwaltungsrecht, VVDStRL Vol. 70 (2010), p. 231. She describes the administrative procedure as a place of development of knowledge generation, information processing, communication and decision-making.

${ }^{84}$ Schuppert, Verwaltungswissenschaft, 2000, p. 795.
} 


\subsubsection{Secondary Problems Raised by Proceduralization}

As mentioned above, a wide range of participants and procedures may lead to lengthy and costly decision-making, which reduces the efficiency of decision-making. Since the administrative risk decisions are often highly complex and regularly require expertise from different disciplines, conducting expert consultation or argumentation, as well as public hearing procedures, may be more economically costly and time-consuming than an individual decision of the administrative authority. However, this problem is not insurmountable, e.g., one can set (regular) deadlines for consultation and decision-making in the relevant law. Participation by different experts raises another problem. For example, recourse to external knowledge can lead to complex problems of allocating the responsibility in relation to scientific and/or technical expertise, which may be decisive for decisions. Moreover, the question of how to avoid a bias of experts, and maintain the independence of their professional opinion from outside interference, raises difficult problems. As regards public participation, when the decisions involve complex processes and multiple actors such as the public at large and interest groups, their representatives do not necessarily represent the will of a particular group or individuals. Moreover, in the context of massive public participation, the responsibility of the decision-making authority for the decision may be reduced, as the authority may be under strong pressure to decide in a particular direction. ${ }^{85}$

5.2 Theoretical Reformulation of the Administrative Decision-making Mechanism on Risk

Against the background that knowledge for risk decision-making cannot regularly be ascertained by simple observation or the learning using the "trial-error" approach, its generation requires the anticipation of complex, potentially non-linear processes and connections and the determination and evaluation of their probability of occurrence by

\footnotetext{
${ }^{85}$ Canenbley, Zweckmäßigkeit von Ausschüssen der Verwendung von Ausschüssen in der Verwaltung, 1968, p. 105.
} 
theory, experiment, and simulation. ${ }^{86}$ In this process, systematical construction occurs both at the substantive and procedural levels. The following section introduces the general administrative decision-making mechanism on uncertain risk, which integrates the abovementioned legal theory response and some other requirements. The focus of this dissertation is on the procedural domain of decision-making, so the material domain of decision-making will be only briefly described below.

\subsubsection{Material Domain}

The inherently uncertain nature of risk decisions is the source of the tendency to retreat from substantive norms and enhance procedural norms. However, the material norms governing administrative decisions must also be adjusted to accommodate to the characteristics of risk. After all, the extent to which the power of intervention of the administrative authorities extends in individual cases is ultimately a question of risk selection or distribution after the fact-finding. ${ }^{87}$

\subsubsection{Aim of Value}

The value objective of administrative risk decisions, i.e., balancing private freedom and the common good, is expressed by, and depends on the concrete statutory provisions and, ultimately, on the constitution..$^{88}$ The uncertain nature of technological risk raises public concern, so the security value is prioritized in administrative risk decisions. However, this value needs to be measured with other legitimate interests regarding the specific administrative decision. The dissertation will not deal with the relevant problems in detail.

\footnotetext{
${ }^{86}$ Scherzberg, Wissen, Nichtwissen und Ungewissheit im Recht, in: Christoph, Engel(ed.), Wissen, Nichtwissen, Unsicheres Wissen, 2002, p.114

87 Scherzberg, Strategien staatlicher Risikobewältigung, in: Hill \& Schliesky (eds.), Management von Unsicherheit und Nichtwissen, 2016, p. 47.

${ }^{88}$ Delhey, Staatliche Risikoentscheidungen, 2014, p. 135; Depenheuer, Das öffentliche Amt, in: Isensee \& Kirchhof (eds.), HStR III (2005), § 36 No. 68.
} 


\subsubsection{Operating Principle: Risk Precaution}

The precautionary principle operates as the dominant principle of risk management in Germany. It also applies under EU legislation, which means that it is also relevant in the direct application of EU environmental law, or in relation to, Germany and the implementation of environmental directives in Germany. The principle of risk precaution (Risikovorsorge) is a behavioral concept, which departs from the proposition that, judging from the current state of knowledge, legal interests may be (possibly) threatened. Even if the nature, extent, probability, and causality of damage are uncertain, the appropriate exante precautionary measures can be taken to prevent or limit the materialization of such risk with low probability or uncertain risk (Risiko). Since precautionary measures respond to different levels of uncertainty and different types of risk situations ${ }^{89}$, risk precaution can only be a highly abstract and generalized concept. Its specific content needs to be determined in the light of the particular circumstances of the risk area in question and in the context of (political) value requirements..$^{90}$

Generally speaking, the core concept of the precautionary principle is that when the exercise of individual freedom may harm the public interest or legitimate private goods such as health and the environment, to a not insignificant extent, the state may take specific precautionary measures to reduce or prevent the occurrence of the harm. With the goal of "avoiding and minimizing possible harm", the precautionary principle requires that specific risk-related opportunities be foregone to create a "margin of safety" (Sicherheitszuschlag) effect. At the same time, since the principle is so abstract and open-ended, the two components of the precautionary principle - the reason of precaution and the precautionary measures - must be defined as precisely as possible on a sliding scale of the security doctrine in order to prevent an "unlimited" interference of power in individual liberty. ${ }^{91}$ To be

\footnotetext{
${ }^{89}$ Some scholars classify risks into four categories based on the degree of uncertainty of knowledge: pure unknown, recognized unknown, abstract concern, and concrete concern, see: Appel, Bedeutung außerrechtlicher Wissensbestände für das Management von Unsicherheit, in: Hill \& Schliesky (eds.), Management von Unsicherheit und Nichtwissen, 2016, p. 113 et seq.

${ }^{90}$ In Germany, there are many interpretations of the specific content of risk precaution. See: Rehbinder, Ziele, Grundsätze, Strategien und Instrumente, in: Rehbinder \& Schink (eds.), Grundzüge des Umweltrechts (5th edition), 2018, p. 164 et seq.; Rehbinder, Das Vorsorgeprinzip im internationalen Vergleich, 1991, p. 9 et seq. ${ }^{91}$ Rehbinder, Ziele, Grundsätze, Strategien und Instrumente, in: Rehbinder \& Schink (eds.), Grundzüge des Umweltrechts (5th edition), 2018, p. 164 et seq.; Appel \& Mielke, Strategien der Risikoregulierung, 2014, p. 109, 161 et seq.; Jaeckel, Gefahrenabwehrrecht und Risikodogmatik, 2010, p. 285 et seq.; Calliess, Das
} 
precise, in order to specify, rationalize and legitimize the precautionary reason and measures, some general procedures and rules are set up to guide, specify, and control the consequences of dealing with uncertainty ${ }^{92}$ In particular, it is necessary to mitigate the conflict between the preventive requirements and the "rule of law barrier" for individual freedom and other principles underlying the rule of law such as legal certainty, proportionality, etc. ${ }^{93}$ Generally speaking, risk precaution consists of, and is bound by, two main elements: the reason for the initiation of precautionary measures, i.e., the possibility of harm (specific risk), and the way of achieving the precautionary goal, i.e., preventive measures. ${ }^{94}$ Therefore, the precautionary principle serves the function of balancing private interests, including freedom of science and technology, and public power for protecting public security.

Both within Germany and at the EU level, risk precaution has the function of legitimizing state action. Its central idea is that the factual basis for predictions can be relaxed and precautionary measures can be taken, even if there is uncertainty, as long as there are sufficient grounds for assuming the existence of facts that give rise to social concern. ${ }^{95}$ The principle does not require that the risk does exist conclusively or that there is no reasonable doubt about the risk. Instead, it is sufficient that there is a severe or plausible indication of a significantly lower risk than that expressed by predominant probability. In sum, the precautionary principle, as a rule of decision making in the face of uncertainty and

\footnotetext{
Vorsorgeprinzip und seine Auswirkungen auf die Nanotechnologie, in: Reiff (ed.), Nanotechnologie als Herausforderung für die Rechtsordnung, 2009, p. 23; Appel, Staatliche Zukunfts- und Entwicklungsvorsorge, 2005, p. 201 et seq.; Calliess, Rechtsstaat und Umweltstaat, 2001, p. 201 et seq.; Wahl \& Appel, Prävention und Vorsorge: Von der Staatsaufgabe zur rechtlichen Ausgestaltung, in: Wahl \& Appel (eds.), Prävention und Vorsorge, 1995, p. 121 et seq.; Rehbinder, Das Vorsorgeprinzip im internationalen Vergleich, 1991, p. 9 et seq.; Ossenbühl, Vorsorge als Rechtsprinzip im Gesundheits-, Arbeits- und Umweltschutz, NVwZ 1986, p. 161.

${ }^{92}$ Appel, Grenzen des Risikorecht, in: Appel, Hermes \& Schönberger (eds.), Festschrift Wahl, 2011, p. 463 ; Appel, Methodik des Umgangs mit Ungewissheit, in: Schmidt-Aßmann (ed.), Methoden der Verwaltungsrechtswissenschaft, 2004, p. 327 et seq.; Scherzberg, Grundlagen staatlicher Risikosteuerung, in: Albers (ed.), Risikoregulierung im Bio-, Gesundheits- und Medizinrecht, 2011, p. 35 et seq.

${ }_{93}$ Ossenbühl, Vorsorge als Rechtsprinzip im Gesundheits-, Arbeits- und Umweltschutz, NVwZ 1986, p. 166 et seq. ; Ladeur, Das Umweltrecht der Wissensgesellschaft, 1995, p. 99 et seq.; Wahl \& Appel, Prävention und Vorsorge: Von der Staatsaufgabe zur rechtlichen Ausgestaltung, in: Wahl \& Appel (eds.), Prävention und Vorsorge, 1995, p. 128.

${ }^{94}$ Calliess, Rechtsstaat und Umweltstaat, 2001, p. 207.

${ }^{95}$ Ladeur, Risiko und Recht, in: Bechmann G. (ed.) Risiko und Gesellschaft. 1993, p. 209 et seq.; Di Fabio, Risikoentscheidungen im Rechtsstaat, 1994, p. 450 et seq.; Di Fabio, Risikosteuerung im öffentlichen Recht, in: Hoffmann-Riem (ed.), Öffentliches Recht und Privatrecht als wechselseitige Auffangordnungen, 1996, p. 147 et seq.; Köck, Grundzüge des Risikomanagements im Umweltrecht, in: Bora (ed.), Rechtliches Risikomanagement, 1999, p. 151 et seq.
} 
ignorance, provides a basis of legitimacy for risk decisions made by state decision-makers based on uncertain predictions, in order to leave a safe distance and a gap for possible future harm, while limiting the costs of waiting due to lack of knowledge. ${ }^{96}$

Nevertheless, German and British scholars have different understandings of the precautionary principle. Since the more the lack of objective factual constraints, the more risk regulation needs to be enriched by normative considerations, and under the influence of the significant differences between countries' own rule of law cultures, different paths of risk precaution have dominated the discussion in the EU: the German risk precaution under the safety doctrine (Sicherheitsdogmatik) and the British risk precaution under a purely risk-based approach. ${ }^{97}$ The difference between these two interpretations does not lie in whether to take precautionary measures but in how to view the components of the precautionary principle. This dissertation adopts the German mainstream view on risk precaution. In the opinion of British scholars, the German abstract precautionary principle is too vague for practical application and is full of exceptions. ${ }^{98}$ To deal with the problem of the high abstraction and openness of the risk precaution principle, the UK has weakened the principle and increased the justification requirements regarding the precautionary reasons and measures by adding a very detailed interpretation standard. ${ }^{99}$

\subsubsection{The Substantive Rule}

\subsection{Cognitive Reference Standard: The State of Art of Science and Technology}

Under conditions of complexity, state decision-making can no longer confine itself to setting permanent rules enabling the formation of common expectations on the basis of "common knowledge"; rather, it must make the maintenance of the generation patterns of knowledge itself its task. ${ }^{100}$ Accordingly, the administration takes on more of the task of knowledge generation. The cognitive reference standard for decision-making expands from

\footnotetext{
${ }^{96}$ Calliess, Rechtsstaat und Umweltstaat, 2001, p. 214.

${ }^{97}$ Appel \& Mielke, Strategien der Risikoregulierung, 2014, p. 5.

${ }_{98}$ Macrory \& Havercroft, Environmental Principles in the United Kingdom, in: Richard Macrory (ed.),

Principles of European Environmental Law, 2004, p. 198.

${ }^{99}$ Appel \& Mielke, Strategien der Risikoregulierung, 2014, p. 1.

${ }^{100}$ Ladeur, Das Umweltrecht der Wissensgesellschaft, 1995, p. 148.
} 
common experience to the "state of the art" of science and technology. However, the "state of the art" always has its downside in the openness for revision. Science not only develops linearly according to certain definitions, but can also and must remain open to self-revision. However, the combination of the administrative need for action and scientific expertise ${ }^{101}$ does not generate special trust if science is geared towards openness.

\subsection{Normative Rules}

In the absence of objective prerequisites for risk assessment, while making an administrative decision on risk, the increase in the extent of regulation needs to be compensated to ensure the legitimacy of administrative decisions as much as possible. The assessment, evaluation, and allocation of risks require a relatively stable normative standard. With this in mind, many doctrinal requirements are set to govern risk assessment. Generally speaking, the normative requirements for the carrying out of risk assessment and evaluation of its conclusions are based on the current state of the art of science and technology.

As for the standard of risk evaluation, first, the risk evaluation should take full account of the value of the protected object or good and the nature of the potential harm. Moreover, the evaluation should be multidimensional, focusing on the degree of certainty of the prediction, the remaining uncertainties, and the corresponding costs that may result from erroneous interventions, etc. ${ }^{102}$ The issue of prioritizing values is also critical here. The prioritization of values affects the evaluation of risks and determines the scope of protection targets for subsequent preventive measures. ${ }^{103}$ It needs to be stated that, theoretically, the evaluation of risk should be separated from the evaluation of legal measures of precaution. However, this theoretical separation can only be maintained to a limited extent in practice, and aspects of risk evaluation and risk management are thus mixed. ${ }^{104}$ Under conditions of

\footnotetext{
${ }^{101}$ Breuer, Gefahrenabwehr und Risikovorsorge im Atomrecht, DVBI 1978, p. 829.

102 Scherzberg, Risiko als Rechtsproblem, VerwArch Vol. 84 (1993); p: 498; Darnstädt, Gefahrenabwehr und Gefahrenvorsorge, 1983, p. 94; Di Fabio, Entscheidungsprobleme der Risikoverwaltung, NuR 1991, p. 355.

${ }^{103}$ Calliess, Rechtsstaat und Umweltstaat, 2001, p. 235.

${ }^{104}$ Ladeur, Das Umweltrecht der Wissensgesellschaft, 1995, p. 219 et seq. ; Calliess, Rechtsstaat und Umweltstaat, 2001, p. 218.
} 
uncertainty, a complete elimination of risks cannot be expected, so that there must be a certain attitude of tolerance towards some of them. In this case, the critical task of the normative rule is to establish normative criteria for the selection of tolerable risks. Secondly, the "principle of inverse proportionality", which is used to determine risk, can also be applied to risk evaluation. According to this principle, the more significant and severe the consequences of a potentially disruptive act, the lower the degree of probability required for a risk determination. Suppose a particular legal interest of high value is at stake. In that case, it should constitute a well-founded reason to assume its future occurrence even if the likelihood of harm occurring is remote. ${ }^{105}$ Advancing a precautionary approach is particularly important in the case of potentially severe and irreversible impacts (e.g., global warming, accumulation of pollutants, loss of critical biodiversity). ${ }^{106}$ Finally, normative risk evaluation is not a once-and-for-all process and must evolve in response to evolving scientific findings. ${ }^{107}$ In a nutshell, risk evaluation presents a value-based trade-off. In this trade-off, the degree of possible harm is included as a decisive factor. If the product of the degree of possible harm and the likelihood of occurrence has a particular normative and decisive value, it should be assumed that the application of preventive measures is justified. ${ }^{108}$

\subsubsection{Procedural Domain}

Due to the inherent combination of both normative and factual uncertainty in risk decisionmaking, the management of this normative and factual uncertainty can only be achieved by appropriate procedural controls. On the one hand, since the knowledge required for decision-making is often not readily verified by experience or readily available, but specialized, fragmented, and uncertain, it must be searched, organized, and constructed within a standardized process. On the other hand, considering the lack of objective facts and the need for supplementary value assessment, it is particularly important to set

\footnotetext{
${ }^{105}$ Stein, Polizei- und Ordnungsrecht auf einen Blick, 2019, p. 6.

${ }^{106}$ Rehbinder, Ziele, Grundsätze, Strategien und Instrumente, in: Rehbinder \& Schink (eds.), Grundzüge des Umweltrechts (5th edition), 2018, p. 180.

107 Ladeur, Privatisierung Öffentlicher Aufgaben und die Notwendigkeit der Entwicklung eines neuen Informationsverwaltungsrechts, in: Hoffmann-Riem \& Schmidt-Aßmann (eds.), Verwaltungsrecht in der Informationsgesellschaft, 2000, p. 235.

108 Scherzberg, Risiko als Rechtsproblem, VerwArch Vol. 84 (1993), p.484, 490.
} 
procedures to coordinate the conflicting interests. Therefore, the constitution of participants and procedure of risk decision-making is not only decisive to ensure the relative comprehensiveness and appropriateness of the collected information for the decision, sequentially affecting the intrinsic rationality and legitimacy of a decision but also to influencing the reconciliation of affected interests and acceptability of a decision outside the sphere of the administration. The composition of participants must first and foremost be oriented at promoting decision-making, taking into account the requirements arising from the type and nature of the risk decision itself, as well as the relevant requirements of the rule of law. Accordingly, the procedure of risk decision-making has to be defined.

\subsubsection{Participants in the Procedure}

Since administrative risk decision-making cannot be predetermined to a certain extent by normative means, the organizational design of the framework is significant and thus places greater demands on compliance with the law and the requirement of certainty. Besides, due to that uncertain risks cannot be eliminated entirely; most of them can only be socially distributed and accepted. Therefore, the admission of plural participants in the administrative risk decision-making is mainly designed to promote the reconciliation of conflicting interests and acceptance of risk, i.e., risk distribution. In other words, the purpose of pluralistic participation is, on the one hand, to reconcile interests and, on the other hand, to allow the allocation of risks that cannot be eliminated to them. The following considerations are intended to help illustrate how the material uncertainty can be compensated for by constructing plural participation and distributing the responsibility of information search or knowledge generation among the participants to the procedure to make the decision-making more effective.

\subsection{Competent Authority}

In administrative risk decision-making, the competent authority is the most influential and ultimately decisive decision-maker in the whole process. Due to the fact that the factual content of the decision can only be determined to a limited extent by normative 
specifications of the decision-making standard, often a margin of appreciation (Beurteilungsspielraum) is granted to the executive. Therefore, its responsibilities and corresponding liability must be clearly defined as by the applicable normative rules in order to ensure fulfillment of the expectations of stability of the counterpart and the pursuance of the common good. Overall, the administrative authority is obliged to work for the common good or balance the common good and private freedom. ${ }^{109}$ The reason that the competent authority shall serve the public good roots in that it is the representation of the "state and by the general public"110. However, the administrative authority is not the (direct) representative of the general public; rather, it is a "representative of the state". ${ }^{111}$. Impartiality of the competent authority is of particular importance. Administrative authorities are obliged "to perform their duties impartially and fairly and to consider the welfare of the general public in the performance of their duties". ${ }^{112}$ They "serve the entire people, not a party", must "perform their duties impartially and fairly and, in the performance of their duties, take the welfare of the general public into consideration". ${ }^{113}$ In the process of risk decision-making, due to the high-tech, uncertain, and widely influential characteristics of risks, a single administrative organ is likely to be unable to analyze the risks comprehensively, weigh the relevant interests, and make relatively rational decisions, so the agents of the decision-making organs involved in risks assessment and management should also be as diverse as possible. Admittedly, there may be differences in the functions they play in the decision-making process and the forms of their participation, for example, as co-decision makers or as consultees, etc.

\subsection{Professional Experts}

Due to the high-technology attributes of uncertain risk, the expert is an indispensable participant in the risk decision-making process. Since risk decisions are characterized by

\footnotetext{
109 Depenheuer, Das öffentliche Amt, in: Isensee \& Kirchhof (eds.), HStR III (2005), § 36 No. 68; Delhey, Staatliche Risikoentscheidungen, 2014, p. 124.

110 Depenheuer, Das öffentliche Amt, in: Isensee \& Kirchhof (eds.), HStR III (2005), § 36 No. 8; Delhey, Staatliche Risikoentscheidungen, 2014, p. 135.

${ }^{111}$ Delhey, Staatliche Risikoentscheidungen, 2014, p. 135.

112 Art. 60 (1) sentence 2, Federal Civil Service Law (Bundesbeamtengesetz - BBG); Delhey, Staatliche Risikoentscheidungen, 2014, p. 157.

113 Battis, Bundesbeamtengesetz. BBG. Kommentar (4th edition), 2009, § 60 No. 5 et seq.; Delhey, Staatliche Risikoentscheidungen, 2014, p. 135.
} 
the complexity of the relevant facts, risk assessment by interdisciplinary expertise is essential. In order to unite the various aspects of a risk decision, to bring together the views of experts from different disciplines, to take full account of the interests involved, and to weigh them up in order to arrive at a holistic assessment ${ }^{114}$, an expert panel should be established that includes experts in relevant disciplines as much as possible.

However, the expert also plays a paradoxical role. Generally, the expertise in one professional domain is also a closely connected with affected stakeholders in the relevant domain, i.e., there is a high degree of coupling of interest representation and technical advice. Specifically, an expert who represents specialist circles and is deeply involved in technical problems is often the best specialist", while "the specialist who usually comes from technical specialist circles" thus to a certain extent inevitably represents the interests of these circles." 115 Dagtoglou pointed out that "the conceptual and practical coupling of interest representation and expert advice is so deep that neither an a priori conceptual nor an empirical-practical distinction in the absolute sense is attainable" ${ }^{116}$ Consequently, a clear personal distinction between interest representative and specialist is not possible ${ }^{117}$ and the "best experts" may also represent the relevant interest holder. ${ }^{118}$ Therefore, maintaining the independence of the expertise in risk decision-making is still a controversial issue. Besides, the constitution of an expert panel is also a problem.

\subsection{Operator}

In the process of administrative risk decision-making, the parties operating a facility or carrying out an activity that may present risks to human health or the environment, such as works with GMOs or release and marketing of GMOs, particularly those who apply to the authorities for requisite approval, are generally subject to a number of obligations, such as submitting certain information, conducting a risk assessment, etc. Considering that the

\footnotetext{
114 Delhey, Staatliche Risikoentscheidungen, 2014, p. 178.

115 Dagtoglou, Der Private in der Verwaltung als Fachmann und Interessenvertreter, 1964, p. 29.

116 Delhey, Staatliche Risikoentscheidungen, 2014, p. 123.

117 Dagtoglou, Der Private in der Verwaltung als Fachmann und Interessenvertreter, 1964, p. 31; Delhey, Staatliche Risikoentscheidungen, 2014, p. 123.

118 Delhey, Staatliche Risikoentscheidungen, 2014, p. 124.
} 
operators have extensive expertise and experience regarding the benefits and risks of the risk activities concerned ${ }^{119}$, it is equally beneficial to the authorities and the applicant or operator to provide the relevant information within the scope of the risk assessment. ${ }^{120}$ As far as the authority is concerned, the obligations of operators facilitate reducing the administration's workload and the time needed to make decisions and thereby improving the procedural efficiency. Generally speaking, the time for decision-making is relatively fixed. If deadlines must be met, reducing the time for an investigation by the administrative body is beneficial because it leaves more time to meet other requirements and ensures that the final decision is made as soon as possible. In the applicant's case, by providing the information themselves, they can assist the decision-maker in making the relevant assessments and conclusions as soon as possible while at the same time guaranteeing that the administrative body investigates the relevant facts as thoroughly and meticulously as possible and takes their own interests fully into account.

Admittedly, the risk investigation or information provided by the operator does not necessarily constrain the administrative authority's independent investigation or reduce the investigative obligations of the authority. On the one hand, this is because, in an authorizing process, the information provided by the applications may not always be objective and comprehensive, so that the administrative agency may need to conduct its own investigation to ensure that the interests of other applicants or adversely affected persons are protected. For example, when there is more than one applicant, where one of the applicants fails to submit specific information or where the information provided does not meet the applicable requirements, the administrative organ should investigate the information further and should not make a decision based on the limited information and at the expense of the interests of other applicants. Therefore, the authority shall attempt to clarify the facts of the case further. On the other hand, in addition to the "comprehensible examination" of the facts brought in by those involved, the authority may still be obliged to conduct independent investigations. ${ }^{121}$ According to the principles of the rule of law, the competent authority is obliged to guarantee a neutral, fair procedure and the legality of its

\footnotetext{
${ }^{119}$ Delhey, Staatliche Risikoentscheidungen, 2014, p. 168.

120 Delhey, Staatliche Risikoentscheidungen, 2014, p. 168.

${ }^{121}$ Delhey, Staatliche Risikoentscheidungen, 2014, p. 169.
} 
actions. The principle of legality, from which the principle of official (ex officio) investigation is derived, demands that the authority subsumes under the law only such facts which really exist.

\subsection{Public}

Integrating the public into the risk decision-making process plays a critical role since they are likely to generate knowledge and enable the reconciliation of conflicting interests. The public includes two groups of people: persons who represent affected interest groups (stakeholders) and the layman, either being affected in his private interests or simply concerned about the public good. While the significance of the participation of interest representatives in the decision-making process naturally goes without saying, laypersons' involvement needs to be justified. In fact, the participation of laypersons, at least those who are not adversely affected but are members of the public at large, instate decisions can be regarded as a kind of direct democracy. It plays special functions: firstly, the layperson can assume the role of "generalist" who brings together the specialized knowledge from various sub-areas ${ }^{122}$, which contributes to the "social opening" of standardization and advisory bodies and to "open break of the social monopoly" of experts and interest representatives; ${ }^{123}$ secondly, their involvement can urge experts presenting his or her technical explanations in a way that is generally understandable, in order to enable not only the laypersons but also the other experts from other specialist groups, who are on an equal footing with the laypersons with regard to the non-specialist areas, to understand what is being presented; ${ }^{124}$ thirdly, the layperson can perform a control function on the administrative decision. ${ }^{125}$ They are not representatives of certain expert circles' interests, enabling them to weigh up conflicting interests and the proportionality of benefits and risks in the sense of the term independently. ${ }^{126}$

\footnotetext{
${ }^{122}$ Laux, Der Einsatz von Entscheidungsgremien, 1979, p. 65.

${ }^{123}$ Beck, Gegengifte. Die organisierte Unverantwortlichkeit, 1986, p. 284.

${ }^{124}$ On the function of jurors - also empirically proven - with regard to promoting the comprehensibility of the conduct of the trial and the justification of the legal decision in detail, see Rennig, Die Entscheidungsfindung durch Schöffen und Berufsrichter in rechtlicher und psychologischer Hinsicht, 1993, p. 285-287, 292, 295-298. 125 Laux, Der Einsatz von Entscheidungsgremien, 1979, p. 66.

${ }^{126}$ Delhey, Staatliche Risikoentscheidungen, 2014, p. 162; Beutin, Die Rationalität der Risikoentscheidung, 2007, p. 226: "Under uncertainty, the risk must therefore be legally procedurally countered, a material control is not possible."
} 


\subsubsection{Procedure}

The administrative procedure is the mirror of a legal system. By regulating relations between the state and its citizens, it illustrates the citizen's position in the legal order and the self-image of the State. The importance of the procedure can hardly be underestimated in the area of state risk decisions. ${ }^{127}$ The following considerations deal with questions about how to construct a discursive, rational decision-making process that allows the expectation of a decision that is as correct as possible and lawful. According to the common international understanding, the risk management framework consists of "risk assessment", "risk communication," and "risk management". Among them, risk assessment refers to "a scientific procedure which uses a factual base to define the health effects of exposure of individuals or populations to hazardous materials and situations". ${ }^{128}$ Risk communication allows for a transparent procedure and a more democratic way to involve all stakeholders in decision-making. ${ }^{129}$ The independence of risk communication emphasizes the public's independent status in modern risk decision-making. It is an institutional setting for supplying legitimacy to modern administrative decision-making. Risk management refers to a process to integrate the scientific concerns based on risk assessment results and other legitimate factors such as social, economic, and political concerns. It aims to reach a "decision of weighing measure alternatives and selecting the most appropriate regulatory action' for decision-makers". ${ }^{130}$ Distinguishing between factual risk assessment and legal risk management at the EU level apparently is a lesson of dealing with evident bureaucratic shortcomings learned from the BSE crisis. However, the distinction does not emphasize the independence of value-based risk evaluation.

In theory, factual risk assessment and legal value-based risk evaluation and legal management should be separate issues, independent of each other, but in fact, they are often

\footnotetext{
${ }^{127}$ Junk, Die Rolle des Verwaltungsverfahrens in Deutschland und England, 2012, p. 19.

${ }^{128}$ Wen Xiang, Risk Governance of GMOs in the EU and IN China, Ghent University, 2012, p. 25.

129 Sensi, A. et al., FAO Biosafety Resource Book, Module C: Risk Analysis, (2011), available at: http://www.fao.org/docrep/014/i1905e/i1905e00.htm

${ }^{130} \mathrm{FAO} / \mathrm{WHO}$. Application of Risk Analysis to Food Standards Issues. Report of the Joint FAO/WHO

Expert Consultation, 13-17 March, 1995, WHO, Geneva; Wen Xiang, Risk Governance of GMOs in the EU and in China, Ghent University, 2012, p71
} 
confounded in practice. ${ }^{131}$ This dissertation frames risk management based on the opinion of Calliess $^{132}$, i.e., distinguishes factual risk assessment, value-based risk evaluation, and risk management. Therefore, according to the functional roles of the different risk decisionmaking phases, administrative risk decision procedures can also be divided into four parts: risk assessment, (value-based) risk evaluation, risk communication, and risk management in the narrow sense. Whereas the (objective) assessment of risk aims to acquire all available sources of knowledge, (value-based) risk evaluation refers to weighting the remaining gaps and uncertainties of facts, mechanisms, and knowledge, as well as individual and public concerns through the (subjective) assessment of risk.

The internationally accepted value-concerned risk evaluation is initially covered by "risk management", which is isolated in this paper. The operation of risk management and (value-based) risk evaluation is, of course, very close. However, the theoretical distinction between the two is made to highlight the specificity in administrative risk decision-making, i.e., the possible value judgment at the level of applying law due to factual uncertainty and the abstraction of legislative norms. (Value-based) risk evaluation is given the independent mission to weigh the risk situation and determine whether a particular risk is acceptable. Against this background, the following considerations are related to selected vital aspects of the design of administrative procedures concerning decisions on risk.

\subsection{Risk Assessment}

The first step in any administrative risk decision is fact-finding by identifying and studying the nature and extent of the risk in question. It is set up as a facilitator of knowledge generation but also a mechanism for the restraint of administrative power. A risk assessment will be required according to minimum legal requirements. ${ }^{133}$ Only on this basis can the

\footnotetext{
${ }^{131}$ Delhey, Staatliche Risikoentscheidungen, 2014, p. 168.

${ }^{132}$ Calliess, Rechtsstaat und Umweltstaat, 2001, p. 214; According to judgment of TestBioTech eV and Others v European Commission (Case T-177/13, ECLI:EU:T:2016:736 Paragraph104), EU case-law also distinguishes between two levels of risk assessment: " risk assessment consists, for the EU institution faced with potentially negative effects stemming from a phenomenon, in assessing, on the basis of a scientific assessment of the risks, whether they exceed the level of risk deemed unacceptable for society". See also: Dow AgroSciences and Others v Commission, T-475/07, EU:T: 2011:445, paragraph 145.

${ }^{133}$ Delhey, Staatliche Risikoentscheidungen, 2014, p. 168 ; Hufen, Fehler im Verwaltungsverfahren, 2002, No. 138.
} 
subsequent steps be taken, i.e., to assess whether the risk is acceptable, communicate the risk information, and decide what measures should be taken to eliminate, reduce, or allocate the risk or duty of care. As mentioned above, since the knowledge required for decision making is not readily available or easily accessible, but specialized, fragmented, and uncertain, it must be searched, organized, and constructed in a standardized process to predict the potential extent (range) of damage and the possibility (probability) of damage presented by the risk situation as well as its uncertainty by nature. Therefore, the administrative authority must make efforts to investigate more risk information, process information, ex-ante predict the attributes of the risk and other elements before making the final decision. ${ }^{134}$ In short, the core function of this step is to solve the problem of knowledge generation, i.e., relating to objective facts, rather than legal evaluation. The main participants in this process are experts and interest representatives because they have more comprehensive knowledge and information. In the risk decision-making process, science and the responsibility for scientific advice are often displaced from the traditional executive framework into independent bodies. ${ }^{135}$ Moreover, science-based statutory terms gain an important steering role. For example, in order to regulate scientific risk identification and assessment, the German Law on Genetic Technology (Gentechnikgesetz - GenTG) and the EU Directive 2001/18/ on the release of genetically modified organisms into the environment both stipulate the state of the art of science and technology (Stand von Wissenschaft und Technik) as an assessment criterion.

However, in the process of risk identification and assessment, several issues cannot be ignored, namely, (1) requisite degree of certainty (the measure of proof) to be gained in the investigation and the degree of clarification on the concrete case, (2) the organization of the expert's participation in the process of assessment and consultation.

Regarding the first question about the degree of certainty (the measure of proof), from a cognitive point of view, this is essentially a question of stop rules. Traditionally, the knowledge of factual rules or experience could be assumed for making a prognosis of possible damage, which acted as the stop-rule, so that the general case investigation did not

\footnotetext{
134 Delhey, Staatliche Risikoentscheidungen, 2014, p. 164.

135 Vos \& Everson, Uncertain Risks Regulated, 2008, p. 3.
} 
need an explicit stop-rule, and decisions could be made based on them. Against the background of lack of experience and relative unified expert opinion, there is a need for setting explicit institutional rules to stop an endless search for information so that a decision can be made based on uncertain or incomplete knowledge. From a legal point of view, this is a matter of principles of investigation and degree of proof. Pursuant to Article $\S 24$ of the German Administrative Procedure Act ( $\mathrm{VwVfG}$ ), the authority is obliged to take into account all circumstances that are important for the individual case, including those favorable to the parties involved. ${ }^{136}$ The determination of the type and scope of the investigation is the responsibility of the competent authority. Since in a situation of uncertain risk, knowledge of factual rules or experience can no longer be assumed, and the uncertainty in the decision-making parameters cannot usually be eliminated entirely, ${ }^{137}$ the way and extent as to which information is searched may be different from that it was in the past.

Generally, if the necessary clarification of the facts cannot be ensured, it is obligatory for the authority to consult (further) experts within the scope of the official investigation. Nevertheless, when making a risk decision, in which there is usually no scientific agreement on assessing a factual situation, the consultation of expert and interest representatives is a necessary process. Besides, the investigation process requires being as open as possible, and approaches that accommodate plural and representative opinions must be set up to ensure that the authority reaches an "adequate basis for a decision". ${ }^{138}$ Rulings of the German constitutional- and administrative courts have also established several requirements for investigation by the executive branch. When, for example, an authority conducts an approval process, it has an obligation to conduct a full investigation. This includes ensuring that the assumptions and evaluations on which the "official safety assessment" based relies on an adequate database and take into account all reasonable scientific findings at the time of the official decision. ${ }^{139}$ It has to consider "all scientifically and technically sound conclusions" ${ }^{140}$, rather than just relying on the "prevailing

\footnotetext{
136 Delhey, Staatliche Risikoentscheidungen, 2014, p. 164.

137 Röhl, Ausgewählte Verwaltungsverfahre, in: Hoffinann-Riemet et al. (eds.), Grundlagen des Verwaltungsrechts Vol. II, 2008, § 30 No. 26-27.

${ }^{138}$ Hufen, Fehler im Verwaltungsverfahren, 2002, No. 133.

${ }^{139}$ Calliess, Rechtsstaat und Umweltstaat, 2001, p. 215.

${ }^{140}$ BVerfGE 49, 89 (140).
} 
opinion" ${ }^{141}$ Besides, as regards the application of the precautionary principle, authorities "can not only make use of existing engineering experience but must also consider protective measures based on considerations and calculations that are "only theoretical" in order to exclude with sufficient reliability risks arising from remaining uncertainties or gaps in knowledge. ${ }^{142}$

Regarding the second question about experts as participants in the procedure, due to the uncertain nature of risk decisions and the fact that they are often complicated, the expertise provided by experts participating in the risk assessment stage should have an interdisciplinary orientation. ${ }^{143}$ In particular, risk assessment procedures should be as consistent as possible with these requirements, such as harmonizing all aspects of risk decision-making, the pooling of experts from different disciplines, the full consideration, and weighing of relevant interests in order to make a comprehensive assessment. To implement these requirements in the design of the risk assessment process, the choice of personnel is crucial; after all, the composition of the members of the expert group will also affect the experts' final conclusions.

\subsection{Risk Communication}

Risk communication is particularly highlighted in modern risk management and is even considered to be at the heart of risk management procedures because of its special value in risk management. ${ }^{144}$ The main reason for setting up a public involvement process is that the resources for government action and the opportunities for effective risk minimization are limited. Simultaneously, the perception of risks and the associated burden depends on individual, social and cultural experiences and assessments. ${ }^{145}$ Taking these issues into account, risk communication is expected to (1) generate more knowledge, such as on local

\footnotetext{
${ }^{141}$ BVerwGE 72, 300 (316).

142 BVerwGE 106,115(121).

${ }^{143}$ Delhey, Staatliche Risikoentscheidungen, 2014, p. 178; Jaeckel, Gefahrenabwehrrecht und Risikodogmatik, 2010, p. 263-265.

${ }^{144}$ Scherzberg, Risk Communication - Information about and Participation in Legal Decision Making regarding Nuclear and other High-Risk Technologies, Osaka University Law Review No. 62 (2015), p. 85 et seq.

145 Scherzberg, Strategien staatlicher Risikobewältigung, in: Hill \& Schliesky (eds.), Management von Unsicherheit und Nichtwissen, 2016, p. 60.
} 
conditions and risk profiles, based on the expression of opinions of different groups; (2) derive value criteria for weighing risks by capturing society's risk preferences, (3) improve citizens' ability to adequately manage the risks of their daily lives by conveying professional opinions and make affected people more likely to accept the distributed risks with their autonomous participation; (4) promote risk decisions to achieve common interests and controlling the administrative power by the procedural set-up.

In order to implement the expected functional value of the public participation process, the question of how to set up the public participation process must be considered. At this point, three questions cannot be ignored: (1) what is the main issue that should be communicated? (2) how to publish the information? (3) how to organize public participation in the decisionmaking mechanism? As for the topics of communication, two types of content are most important. The current state and limitations of risk knowledge should be one of the subjects of risk communication, in particular existing expert knowledge, uncertain and controversial areas of knowledge, and gaps in the current knowledge base. Only by adequately informing the public of the current state of knowledge can the public have an objective expectation of risk and think about the next step of risk acceptance or rejection. Individual perception of risk and typical errors in individual and societal risk perceptions are another subject of risk communication. The expression of personal risk perception is not only a way to generate knowledge but also a way to form risk evaluation criteria and guide the operation of administrative power. As for the issue of publishing information and organization of public participation, there has been a large amount of literature on these issues. Therefore, this dissertation will deal with the details here.

\subsection{Risk Evaluation}

Following the risk assessment and risk communication, the authorities weigh the remaining gaps and uncertainties in facts, systems, knowledge, and individual and public concerns based on preliminary scientific data and decide whether the risk is (subjectively) "acceptable."146 This process is named risk evaluation (value-based risk assessment). Risk

\footnotetext{
146 Murswiek, Die Bewältigung der wissenschaftlichen und technischen Entwicklungen durch das Verwaltungsrecht, VVDStRL 48 (1990), p. 217 et seq.; Calliess, Rechtsstaat und Umweltstaat, 2001, p. 219.
} 
evaluation can be regarded as "establishing the relationship between the legal and technical side of the decision-making process" ${ }^{147}$ The determination of risk in the legal sense is not something absolutely and objectively inherent but a question of a combination of relatively objective factual identification (assessment) and value or normative evaluation. Prior to the advent of the risk society, the determination of danger had relatively objective and specific empirical public knowledge or technology to predict the "product" of the probability of occurrence and the degree of damage, and it also had established (legislative) values and (applicable) norms to determine the risk to be regulated. However, due to the difficulty or unavailability of "damage prediction" as a basis of rationality, the need for evaluation standards is highlighted in the risk society context.

In particular, it must be noted that in a modern state governed by the rule of law, risk assessment cannot be merely a scientific and professional matter. Because of its added value, it can only be carried out by constitutionally mandated and legally bound State organs and integrated into the decision-making process under the rule of law. No scientific opinion, however, can replace the formation of political views and evaluative decision-making. Thus, scientific experts have only an advisory or recommendatory function. ${ }^{148}$ The same is true for the expression of opinions of the public in the process of risk communication. The purpose of the procedures for risk evaluation is to minimize uncertainty before decisions are made, identify and assess the consequences of uncertainty, and finally address residual uncertainty through strategies to avoid or minimize it. The overall objective is to legally rationalize the (risk) decisions to be taken, by procedural design, in the absence of an adequate basis for prediction. ${ }^{149}$

\subsection{Risk Management}

Once risk is assessed and evaluated, regulatory agencies shall consider risk management, i.e., make the final decision. Following the factual identification and normative evaluation

\footnotetext{
147 Delhey, Staatliche Risikoentscheidungen, 2014, p. 168; Hufen, Fehler im Verwaltungsverfahren, 2002, No. 132.

148 Calliess, Rechtsstaat und Umweltstaat, 2001, p. 218.

${ }^{149}$ Scherzberg, Risikoabschätzung unter Ungewissheit, ZUR Vol. 6 (2010), p. 303
} 
of the uncertain risk, the risk management process determines whether precautionary measures are to be taken. In that case, risk management is the process of adopting the appropriate restrictions or controls on a product or practice needed to reduce the risk to acceptable levels, achieving the goal that possible environmental damage should be avoided and minimized as much as possible. ${ }^{150}$ However, under conditions of uncertainty, risk management measures themselves are usually risky. If the type of risk or the probability of occurrence of damage cannot be predicted, and the consequences of the risk minimization measures under consideration cannot be either predicted with confidence, then secondorder risks arise in addition to those that need to be managed: the risk of misjudgment of uncertain risk. ${ }^{151}$ Therefore, the purpose of precautionary measures cannot simply be to eliminate or minimize risks but also need to reflect the secondary risks and select the relevant measures responsibly. ${ }^{152}$

The German doctrine of risk precaution imposes numerous requirements and restrictions on precautionary measures: certainty and clarity of content, as well as the need for justification, determination of value priorities, the guarantee of fundamental rights, compliance with the traditional rule of law principles such as proportionality. ${ }^{153}$ Since legal measures cannot solve all problems simultaneously and with the same intensity, the establishment of criteria for selecting priorities among the relevant values is critical in choosing precautionary measures. ${ }^{154}$ As already mentioned above, the evaluation of risk and the evaluation of preventive measures require clear criteria of measurement at the value level, and the value goals, which are established by the applicable norms, become the specific goals of precautionary measures. ${ }^{155}$

\footnotetext{
${ }^{150}$ Calliess, Rechtsstaat und Umweltstaat, 2001, p. 169.

${ }^{151}$ Augsberg, Von der Gefahrenabwehr zu Risikomanagement und Opportunitätswahrnehmung, in: Peter \& Funcke (ed.), Wissen an der Grenze, 2013, p. 218.

${ }^{152}$ Scherzberg, Risikosteuerung durch Verwaltungsrecht: Ermöglichung oder Begrenzung von Innovationen?, VVDStRL Vol. 63 (2004), p. 214.

${ }^{153}$ According to the Judgement of EU cases such as TestBioTech eV and Others v European Commission (Case T-177/13, ECLI:EU:T:2016:736 Paragraph 77), Dow AgroSciences and Others v Commission (Case T-475/07, EU:T:2011:445, paragraph 148), in the interests of protecting human health, it is necessary to take preventive measures in spite of any existing scientific uncertainty.

${ }^{154}$ Rehbinder, Ziele, Grundsätze, Strategien und Instrumente, in: Rehbinder \& Schink (eds.), Grundzüge des Umweltrechts (5th edition), 2018, p.165.

155 Calliess, Rechtsstaat und Umweltstaat, 2001, p. 235.
} 
Needless to say, the most controversial constraint on precautionary measures is the application of the principle of proportionality. This is reflected by the justification requirement. The question is as to how much effort must be made to determine how suitable and necessary risk precautionary measures need to be to achieve the goals sought and how extensive and intense the risk regulation (prevention) measures need to be in order to (still) be able to affirm the necessity and proportionality (adequacy) of these measures. In general, the principle of proportionality requires the suitability (Geeignetheit), necessity (Erforderlichkeit), and proportionality or adequacy (Angemessenheit) of measures of intervention. It operates without problems under established factual premises, but its application becomes problematic under conditions of uncertainty. The principle of proportionality and the principle of risk precaution are structurally open principles, and uncertain conditions make it difficult to assess the proportionality of the relevant intervention measures. How to concretize these two principles and relate them to each other is still a question.

According to the British interpretation, precautionary measures cannot be justified by general reasons such as "minimization of risk" or "avoidance of harmful effects on the environment". Instead, they must be set out in as much detail and clarity as possible and identified and justified. The UK has many specific requirements for principles governing risk precaution, taking into account its own rule of law culture and risk regulation strategy. ${ }^{156}$ First, the justification of intervention that addresses "potential risk" relies heavily on scientific findings. Despite the difficulties and uncertainties associated with detailed damage prediction, the approach requires standardized and formalized risk identification, assessment, and evaluation designed to be as objective and rational as possible. Doing so requires exhausting the available sources of knowledge, being as cognizant as possible of the specific hazards and risks, the causes of social concern, and of which risks require intervention. Only scientifically sound reasons can limit individual freedom and consume resources for the operation of the state institutions. However, it must be noted that even in the German precautionary practice, a more or less formalized risk assessment

\footnotetext{
156 Fisher, Drowning by Numbers: Standard Setting in Risk Regulation and the Pursuit of Accountable Public Administration, Oxford Journal of Legal Studies 2000, p. 109; Appel \& Mielke, Strategien der Risikoregulierung, 2014, p. 50; Fehling, Kosten - Nutzen - Analysen als Maßstab für Verwaltungsentscheidungen, VerwArch Vol. 95 (2004), p.443.
} 
normally precedes the application of the precautionary principle, which response to uncertainties that are not removed by the assessment. Secondly, in the British understanding, the scope of risk evaluation factors is to be expanded, and in particular, "risk (cost)-benefit" analysis of risks should be prioritized. Based on risk (cost)-benefit considerations, the risk evaluation also includes political and social factors, as well as the need to expend state resources in relation to the scope and extent of the individual risk potential. This leads to a significantly increased burden of justification and argumentation for precautionary strategies. ${ }^{157}$ As traditionally understood in Germany, economic considerations play a role only at the level of assessing the proportionality of precautionary measures and can be (kept) within a narrow range even when only reasonable assumptions of risk can be made, given the strong legitimacy of the precautionary principle.

\subsection{Summary}

Risk management oriented at risk precaution, which constitutes a development of traditional doctrinal danger prevention, needs to assume at least two major tasks at the same time: The first task is to construct the learning ability of law in the legal system. In detail, the law needs to reduce the application of the ex-post knowledge generation approach based on "trial and error" and increase the design of knowledge generation systems at the front and middle ends of risk decision-making, continuously expanding the knowledge boundaries, reducing uncertainty, recognizing the consequences of remaining uncertainty, and ensuring that the legal system and administrative risk decision-making are flexibly and continuously adapted to the new knowledge base. ${ }^{158}$ The regimes for knowledge generation include risk assessment, public participation, authorized administrative discretion, etc. The second task is risk reduction and risk allocation. Specifically, legal decision-makers need to: consider the different risk preferences of society, establish value evaluation standards, establish priority of value standards to determine the socially acceptable level of risk, generate "avoidance or minimization strategies" to deal with remaining uncertainty, and ensure the legitimacy of administrative decisions. ${ }^{159}$ The underpinning legal regime

\footnotetext{
${ }^{157}$ Appel \& Mielke, Strategien der Risikoregulierung, 2014, p.166.

158 Ladeur, Das Umweltrecht der Wissensgesellschaft, 1995, p. 11.

159 Scherzberg, Grundlagen staatlicher Risikosteuerung, in: Albers (ed.), Risikoregulierung im Bio-, Gesundheits- und Medizinrecht, 2011, p. 35 et seq.; Appel, Bedeutung außerrechtlicher Wissensbestände für
} 
especially includes risk precaution, public participation, and delegated administrative decision-making in the shape of granting the administration a margin of appreciation and discretion, and proceduralization.

das Management von Unsicherheit, in: Hermann Hill (ed.), Management von Unsicherheit und Nichtwissen, 2016, p. 113 et seq. 
6 Concrete Administrative Decision-making on Risk regarding the Authorization for Agricultural GMOs: Comparing Germany/the EU and China

The general theory of administrative risk decision-making discussed in chapters 4 and 5 reflects the theoretical problems in GMO risk decision-making. Chapter 6 pays close attention to the specific provisions regarding the GMO risk decision-making. Since uncertain risk of green GMOs is among the most controversial technological issues in China and Germany/the EU, this chapter focuses on how general administrative risk decisionmaking theories are embodied in Germany/the EU and China's legislation. There are five sections in this chapter. Firstly, the GMO regulatory framework in Germany/the EU and China will be introduced, respectively (Section 6.1). Then, section 6.2 generalizes the categories of GMO-related administrative decision-making in both countries. Finally, section 6.3 examines five elements of administrative risk decision-making in GMO legislation.

\subsection{Overview of the Regulatory Framework on GMOs}

\subsubsection{Germany/the EU}

Against the backdrop of EU integration and harmonization by uniform EU legislation, Germany's presently valid regulatory framework on green GMOs consists of national legislation, such as Gentechnikgesetz (hereafter GenTG), and European rules, such as Directive 2001/18/EC. Based on the designed use of GMOs, this normative framework is divided into two groups: GMOs for general use and for food and feed use.

At the EU level, rules on GMOs for general use are primarily laid down by directives, which assign the main enforcement tasks to the Member States' authorities, and on which member states have to orient their domestic law. ${ }^{1}$ The EU framework for GMOs for general use consists, in particular, of Directive 2001/18/EC, Regulation (EC) No 1830/2003, Regulation (EC) No 1946/2003, Commission Decision No 2004/204/EC, Commission Regulation (EC)

\footnotetext{
${ }^{1}$ Rehbinder, Ziele, Grundsätze, Strategien und Instrumente, in: Rehbinder \& Schink (eds.), Grundzüge des Umweltrechts (5th edition), 2018, p. 68.
} 
No 65/2004, Directive 2009/41, Directive 2015/412, Regulation (EU) 2019/1381. Among them, Directive 2001/18/EC plays a central role in regulating the authorization of GMOs. In contrast, concerning GMOs for a particular use, i.e., for food and feed use, the EU has used the directly applicable legislative form of "Regulation" to uniformly regulate GMOs for food and feed use on the European market, leaving limited discretionary leeway for each member state. The separate regulatory group regulating GM food and feed is constituted by Regulation (EC) No 1829/2003, Commission Regulation (EC) No 641/2004, Commission Regulation (EC) No 1981/2006, etc. In this group, the main rules relating to GMO authorization are laid down in Regulation (EC) No 1829/2003. Simultaneously, several other laws are also concerned with GMOs, such as Regulation (EC) No 178/2002². As for these laws, this chapter will not present them separately here.

At German domestic level, a series of national laws on GMOs are determined in their essential features by European Directives. The German regulatory framework is centered on the Gentechnikgesetz (GenTG), which was promulgated in 1990. To implement and concretize the provisions of Gentechnikgesetz, several regulations were issued. Together with Gentetchnikgesetz, several implemeting regulations) form the domestic legal system for GMOs in Germany. These are the Gentechnik-Anhörungsverordnung (herafter GenTAnhV) , Gentechnik-Verfahrensverordnung (hereafter GenTVfV) , ZKBSVerordnung (hereafter ZKBSV), Gentechnik-Sicherheitsverordnung (hereafter GenTSV), Gentechnik-Aufzeichnungsverordnung (hereafter GenTAufzV) , GentechnikBeteiligungsverordnung (hereafter GenTBetV), Gentechnik-Notfallverordnung (hereafter GenTNotfV)， EG-Gentechnik-Durchführungsgesetz(hereafter EGGenTDurchfG), and Gentechnik-Pflanzenerzeugungsverordnung (hereafter GenTPflEV). The domestic legislation, on the one hand, constitute a reception of the relevant EU directives, on the other hand, complement EU legislation. The governance on GMOs for food and feed use is dominated by EU regulations, thus, there is no need to adopt similar domestic rules in Germany.

Since the keynote of this dissertation is to explore the administrative risk decision-making

\footnotetext{
2 Regulation (EC) No 178/2002 on the general principles and requirements of food law, establishing the European Food Safety Authority, and laying down procedures in matters of food safety.
} 
on green GMOs, i.e., the authorization of GMOs, the following subsections will selectively introduce the relevant legislation, namely, Directive 2001/18/EC, Gentechnikgesetz and Regulation (EC) No 1829/2003. Besides, as the contained use of or research on GMOs does not cause too much social controversy, this dissertation will not discuss it. The focus is further narrowed down to authorizations relating to GMOs in the form of releasing and marketing. The three tables below contain a more detailed list of GMO rules adopted by the EU and Germany. 
Regulations on GMOs for general use in the EU

\begin{tabular}{|c|c|c|c|}
\hline $\begin{array}{l}\text { Name of } \\
\text { Regulations }\end{array}$ & Validity period & $\begin{array}{l}\text { Promulgation } \\
\text { Department }\end{array}$ & Brief Introduction \\
\hline $\begin{array}{l}\text { Directive } \\
\text { 2001/18/EC }\end{array}$ & $\begin{array}{lr}\text { Since } 2001 & \text { (last } \\
\text { amended } & \text { by } \\
\text { Regulation } & \text { (EU) } \\
\left.2019 / 1381^{2}\right) & \end{array}$ & $\begin{array}{l}\text { The European } \\
\text { Parliament and the } \\
\text { Council }\end{array}$ & $\begin{array}{l}\text { It is one of the most crucial directives governing GMO activities in the EU, which } \\
\text { provides detailed rules for granting consent for GMOs' deliberate release and } \\
\text { marketing. The governing regimes, such as labeling, risk assessment, monitoring } \\
\text { and register of the GMOs, are also generally provided. }\end{array}$ \\
\hline $\begin{array}{l}\text { Regulation (EC) } \\
\text { No } 1946 / 2003^{3}\end{array}$ & Since 2003 & $\begin{array}{l}\text { The European } \\
\text { Parliament and of the } \\
\text { Council }\end{array}$ & $\begin{array}{l}\text { This regulation covers the general GMOs and the GMOs for food and feed use } \\
\text { regulating their transboundary movements. }\end{array}$ \\
\hline $\begin{array}{l}\text { Regulation (EC) } \\
\text { No } 1830 / 2003^{4}\end{array}$ & $\begin{array}{l}\text { Since } 2003 \text { (last } \\
\text { amended } \quad \text { by } \\
\text { Regulation (EU) }\end{array}$ & $\begin{array}{l}\text { The European } \\
\text { Parliament and the } \\
\text { Council }\end{array}$ & $\begin{array}{l}\text { This regulation is designed to regulate the tracking and labeling of GMOs, which is } \\
\text { authorized for marketing, including the products containing GMOs and food and } \\
\text { animal feed derived from them. }\end{array}$ \\
\hline
\end{tabular}

${ }^{1}$ Directive 2001/18/EC of the European Parliament and of the Council of 12 March 2001 on the deliberate release into the environment of genetically modified organisms and repealing Council Directive 90/220/EEC - Commission Declaration

2 Regulation (EU) 2019/1381 of the European Parliament and of the Council of 20 June 2019 on the transparency and sustainability of the EU risk assessment in the food chain and amending Regulations (EC) No 178/2002, (EC) No 1829/2003, (EC) No 1831/2003, (EC) No 2065/2003, (EC) No 1935/2004, (EC) No 1331/2008, (EC) No 1107/2009, (EU) 2015/2283 and Directive 2001/18/EC

${ }^{3}$ Regulation (EC) No 1946/2003 of the European Parliament and of the Council of 15 July 2003 on transboundary movements of genetically modified organisms

${ }^{4}$ Regulation (EC) No 1830/2003 of the European Parliament and of the Council of 22 September 2003 concerning the traceability and labelling of genetically modified organisms and the traceability of food and feed products produced from genetically modified organisms and amending Directive 2001/18/EC 


\begin{tabular}{|c|c|c|c|}
\hline & $\left.2019 / 1243^{5}\right)$ & & \\
\hline $\begin{array}{l}\text { Commission } \\
\text { Decision No } \\
\text { 2004/204/EC }{ }^{6}\end{array}$ & Since 2004 & $\begin{array}{l}\text { The Commission of the } \\
\text { European Communities }\end{array}$ & $\begin{array}{l}\text { This decision mainly provides detailed rules for the registration of GMOs according } \\
\text { to the Directive 2001/18, to ensure the traceability of the GMOs and the public's } \\
\text { right to know }\end{array}$ \\
\hline $\begin{array}{l}\text { Commission } \\
\text { Regulation (EC) } \\
\text { No } 65 / 2004^{7}\end{array}$ & Since 2004 & $\begin{array}{l}\text { The Commission of the } \\
\text { European Communities }\end{array}$ & $\begin{array}{l}\text { The regulation sets out a system for establishing a unique identifier for the GMOs. } \\
\text { Except for medicinal products, all GMs, including those that have been authorized, } \\
\text { must be coded in a uniform format. }\end{array}$ \\
\hline $\begin{array}{l}\text { Directive } \\
\text { 2009/41/EC }{ }^{8}\end{array}$ & Since 2009 & $\begin{array}{l}\text { The European } \\
\text { Parliament and the } \\
\text { Council }\end{array}$ & $\begin{array}{l}\text { This directive is mainly designed to regulate the contained use of genetically } \\
\text { modified microorganisms. The term "contained use" covers any activity involving } \\
\text { genetically modified micro-organisms (including viruses, viroids, animal and plant } \\
\text { cells in culture) that are carried out under containment to limit contact of these } \\
\text { organisms with the environment. Such activities include genetic modification, the } \\
\text { use, storage, transport, destruction, and disposal of GM microorganisms. } \\
\text { According to the directive, the operators of any contained use shall inform the local }\end{array}$ \\
\hline
\end{tabular}

${ }^{5}$ Regulation (EU) 2019/1243 of the European Parliament and of the Council of 20 June 2019 adapting a number of legal acts providing for the use of the regulatory procedure with scrutiny to Art. 290 and 291 of the Treaty on the Functioning of the European Union

${ }^{6}$ Commission Decision of 23 February 2004 laying down detailed arrangements for the operation of the registers for recording information on genetic modifications in GMOs, provided for in Directive 2001/18/EC of the European Parliament and of the Council

${ }^{7}$ Commission Regulation (EC) No 65/2004 of 14 January 2004 establishing a system for the development and assignment of unique identifiers for genetically modified organisms

${ }^{8}$ Directive 2009/41/EC of the European Parliament and of the Council of 6 May 2009 on the contained use of genetically modified micro-organisms 


\begin{tabular}{|c|c|c|c|}
\hline & & & $\begin{array}{l}\text { authorities. The directive divides the GMMs into four grades based on risk }{ }^{9} \text { and sets } \\
\text { individual application requirements, assigned containment levels, and protective } \\
\text { measures. For class } 3 \text { and class } 4 \text {, the applicant can only implement the contained } \\
\text { use after notifying the authorities and obtaining consent. Meanwhile, the authorities } \\
\text { verify that the installation is appropriate for the activity and that the work does not } \\
\text { pose a significant danger to human health and the environment. In addition, in an } \\
\text { emergency, the Directive explicitly sets out requirements for users and authorities. } \\
\text { At last, particular emphasis is placed on the protection of confidential information. } \\
\text { Because contained use has caused less public concern, it will not be further discussed } \\
\text { in the dissertation. }\end{array}$ \\
\hline $\begin{array}{l}\text { Directive } \\
2015 / 412^{10}\end{array}$ & Since 2015 & $\begin{array}{l}\text { The European } \\
\text { Parliament and the } \\
\text { Council }\end{array}$ & $\begin{array}{l}\text { This directive sets up the rules that, firstly, during the authorization procedure: } \\
\text { Member State can ask to amend the geographical scope of the application to ensure } \\
\text { that the EU authorization will not cover its territory; Secondly, after a GMO has } \\
\text { been authorized: a Member State may prohibit or restrict the cultivation of the crop } \\
\text { based on grounds related amongst others to environmental or agricultural policy }\end{array}$ \\
\hline
\end{tabular}

9. Class 1 covers activities of no or negligible risk

- $\quad$ Class 2 covers activities of low risk

- Class 3 covers activities of moderate risk

Class 4 covers activities of high risk

${ }^{10}$ Directive (EU) 2015/412 of the European Parliament and of the Council of 11 March 2015 amending Directive 2001/18/EC as regards the possibility for the Member States to restrict or prohibit the cultivation of genetically modified organisms (GMOs) in their territory 


\begin{tabular}{|l|l|l|l|}
\hline & & & $\begin{array}{l}\text { objectives, or other compelling grounds such as town and country planning, land } \\
\text { use, socio-economic impacts, co-existence, and public policy. }\end{array}$ \\
\hline $\begin{array}{l}\text { Regulation (EU) } \\
2019 / 1381\end{array}$ & Since 2019 & $\begin{array}{l}\text { The European } \\
\text { Parliament and the } \\
\text { Council }\end{array}$ & $\begin{array}{l}\text { This Regulation laid down detailed requirements to ensure transparency, promote } \\
\text { comprehensive risk communication, ensure the independence and robustness of } \\
\text { submitted scientific studies, strengthen cooperation between government and } \\
\text { scientists, etc. }\end{array}$ \\
\hline
\end{tabular}


Regulations on GMOs for food and feed use in the EU

\begin{tabular}{|c|c|c|c|}
\hline $\begin{array}{l}\text { Name of } \\
\text { Regulations }\end{array}$ & Validity period & $\begin{array}{l}\text { Promulgation } \\
\text { Department }\end{array}$ & Brief Introduction \\
\hline $\begin{array}{l}\text { Regulation (EC) } \\
\text { No } 1829 / 2003^{1}\end{array}$ & \begin{tabular}{|lr} 
Since 2003 & (last \\
amended & by \\
Regulation & (EU) \\
2019/1381) &
\end{tabular} & $\begin{array}{l}\text { The European } \\
\text { Parliament and the } \\
\text { Council }\end{array}$ & $\begin{array}{l}\text { This regulation is the central legislation for the governance of the GMOs for food } \\
\text { and feed use and cultivation. The authorization, labeling, and supervision are laid } \\
\text { down thereof. }\end{array}$ \\
\hline $\begin{array}{l}\text { Commission } \\
\text { Regulation (EC) } \\
\text { No } 641 / 2004^{2}\end{array}$ & $\begin{array}{lr}\text { Since 2004 } & \text { (last } \\
& \\
\text { amended } & \text { by } \\
\text { Regulation } & \\
\left.503 / 2013^{3}\right) & \end{array}$ & $\begin{array}{l}\text { The Commission of the } \\
\text { European Communities }\end{array}$ & $\begin{array}{l}\text { This regulation mainly provides detailed rules concretizing Regulation No } \\
1829 / 2003 \text { on the documents that need to be submitted by the applicant. The annex } \\
\text { specifies information on the test methods that the applicant needs to submit. } \\
\text { However, the requirements do not apply to the permission under Commission } \\
\text { Implementing Regulation (EU) No 503/2013, i.e., food and feed related to } \\
\text { genetically modified plants. }\end{array}$ \\
\hline $\begin{array}{l}\text { Commission } \\
\text { Regulation (EC) }\end{array}$ & Since 2006 & $\begin{array}{l}\text { The Commission of the } \\
\text { European Communities }\end{array}$ & $\begin{array}{l}\text { This regulation mainly concerns the operation of community reference laboratory } \\
\text { for GMOs, especially the collection of funds and cooperation with member }\end{array}$ \\
\hline
\end{tabular}

${ }^{1}$ Regulation (EC) No 1829/2003 of the European Parliament and of the Council of 22 September 2003 on genetically modified food and feed

${ }^{2}$ Commission Regulation (EC) No 641/2004 of 6 April 2004 on detailed rules for the implementation of Regulation (EC) No 1829/2003 of the European Parliament and of the Council as regards the application for the authorisation of new genetically modified food and feed, the notification of existing products and adventitious or technically unavoidable presence of genetically modified material which has benefited from a favourable risk evaluation

${ }^{3}$ Commission Implementing Regulation (EU) No 503/2013 of 3 April 2013 on applications for authorization of genetically modified food and feed in accordance with Regulation (EC) No 1829/2003 of the European Parliament and of the Council and amending Commission Regulations (EC) No 641/2004 and (EC) No 1981/2006 


\begin{tabular}{|c|c|c|c|c|}
\hline No $1981 / 2006^{4}$ & & & & laboratories. \\
\hline $\begin{array}{l}\text { Commission } \\
\text { Implementing } \\
\text { Regulation (EU) } \\
\text { No 503/2013 }\end{array}$ & Since 2013 & $\begin{array}{l}\text { The } \\
\text { Parliament } \\
\text { Council }\end{array}$ & $\begin{array}{l}\text { European } \\
\text { and the }\end{array}$ & $\begin{array}{l}\text { This Regulation is a very technical enforcement regulation. Since experience in GM } \\
\text { plants is relatively more mature and safe, and the applications for it occupy the } \\
\text { majority, this norm regulates food and feed consisting of or containing genetically } \\
\text { modified plants. It replaces some of the provisions of Regulation 641/2004. Some } \\
\text { scientific requirements for genetically modified plants' application materials are } \\
\text { provided in this Implementing Regulation; for example, research, risk assessment, } \\
\text { tracking, adjustment, judgment, and other related materials. There are two } \\
\text { additional annexes, which specify in great detail the requirements that the } \\
\text { applicant's application materials need to meet in order to facilitate subsequent EU } \\
\text { review. }\end{array}$ \\
\hline
\end{tabular}

\footnotetext{
${ }^{4}$ Commission Regulation (EC) No 1981/2006 of 22 December 2006 on detailed rules for the implementation of Art. 32 of Regulation (EC) No 1829/2003 of the European Parliament and of the Council as regards the Community reference laboratory for genetically modified organisms
} 
Regulations on GMOs in Germany

\begin{tabular}{|c|c|c|c|}
\hline Name of Regulations & $\begin{array}{l}\text { Validity } \\
\text { period }\end{array}$ & $\begin{array}{l}\text { Promulgation } \\
\text { Department }\end{array}$ & Brief Introduction \\
\hline enetic Technology (GenTG1) & $\begin{array}{l}\text { Since } \\
1990 \text { (last } \\
\text { amended } \\
\text { in 2020) }\end{array}$ & $\begin{array}{l}\text { German } \\
\text { Federal } \\
\text { Parliament }\end{array}$ & $\begin{array}{l}\text { The GenTG is the fundamental national law in the field of genetic } \\
\text { engineering. It is intended to protect both from the dangers of genetic } \\
\text { engineering and enable GMOs to be explored and exploited. It essentially } \\
\text { regulates works with GMOs, for example, in laboratories, the prerequisites } \\
\text { for limited releases of GMOs, including their time and area, and the } \\
\text { prerequisites for the marketing of GMOs. }\end{array}$ \\
\hline $\begin{array}{l}\text { Regulation on Hearing Procedures } \\
\text { according to the Law on Genetic } \\
\text { Technology }\left(G e n T A n h V^{2}\right)\end{array}$ & $\begin{array}{l}\text { Since } \\
1990 \text { (last } \\
\text { amended } \\
\text { in 2008) }\end{array}$ & $\begin{array}{l}\text { German } \\
\text { Federal } \\
\text { Government }\end{array}$ & $\begin{array}{l}\text { The Regulation regulates the details of the public consultation relating tc } \\
\text { the release of GMOs or the establishment of genetic engineering } \\
\text { installations. The application for the respective project or release must be } \\
\text { published in the affected municipality. Citizens can raise their objections } \\
\text { within a certain period, which may be discussed at a hearing. }\end{array}$ \\
\hline $\begin{array}{l}\text { Regulation on the Documents for } \\
\text { Application and Registration and on the } \\
\text { Procedures for Authorization and }\end{array}$ & $\begin{array}{l}\text { Since } \\
1990 \text { (last } \\
\text { amended }\end{array}$ & $\begin{array}{l}\text { German } \\
\text { Federal } \\
\text { Government }\end{array}$ & $\begin{array}{l}\text { The Regulation regulates in detail the documents to be submitted by the } \\
\text { applicant to the competent authority. Also, in conjunction with European } \\
\text { legislation, it standardizes that so-called simplified procedures can be usec }\end{array}$ \\
\hline
\end{tabular}

${ }^{1}$ Gesetz zur Regelung der Gentechnik (Gentechnikgesetz - GenTG)

${ }^{2}$ Verordnung über Anhörungsverfahren nach dem Gentechnikgesetz (Gentechnik-Anhörungsverordnung - GenTAnhV) 


\begin{tabular}{|c|c|c|c|}
\hline $\begin{array}{l}\text { Registration According to the Law on } \\
\text { Genetic Technology }\left(G^{2} T_{V f V}{ }^{3}\right)\end{array}$ & in 2019) & & for the post-registration of sites. \\
\hline $\begin{array}{l}\text { Regulation on the Central Commission for } \\
\text { Biosafety }\left(\mathrm{ZKBSV}^{4}\right)\end{array}$ & $\begin{array}{l}\text { Since } \\
1990 \text { (last } \\
\text { amended } \\
\text { in 2019) }\end{array}$ & $\begin{array}{l}\text { German } \\
\text { Federal } \\
\text { Government }\end{array}$ & $\begin{array}{l}\text { The Regulation regulates the activities of the Central Commission for } \\
\text { Biosafety to ensure the rationality of risk assessment on GMOs. }\end{array}$ \\
\hline $\begin{array}{l}\text { Regulation on Safety Levels and Safety } \\
\text { Measures During the Genetic Technological } \\
\text { Research in Genetic Technological } \\
\text { Installations (GenTSV5) }\end{array}$ & $\begin{array}{l}\text { Since } \\
1990 \text { (last } \\
\text { amended } \\
\text { in 2013) }\end{array}$ & $\begin{array}{l}\text { German } \\
\text { Federal } \\
\text { Government }\end{array}$ & $\begin{array}{l}\text { The regulation contains safety requirements for genetic engineering in } \\
\text { genetic engineering installations and standardizes safety requirements for } \\
\text { releases. }\end{array}$ \\
\hline $\begin{array}{l}\text { Regulation on Labeling During the Genetic } \\
\text { Technological Research and Release } \\
\left(\text { GenTAufzV }^{6}\right)\end{array}$ & $\begin{array}{l}\text { Since } \\
1990 \text { (last } \\
\text { amended } \\
\text { in 2008) }\end{array}$ & $\begin{array}{l}\text { German } \\
\text { Federal } \\
\text { Government }\end{array}$ & $\begin{array}{l}\text { The Regulation lays down the records which must be kept when carrying } \\
\text { out genetic works or releases, how these must be kept and submitted to the } \\
\text { competent authority at its request. }\end{array}$ \\
\hline Federal Cost Regulation to the Law on & $\begin{array}{l}\text { Since } \\
1990 \text { (last }\end{array}$ & $\begin{array}{l}\text { German } \\
\text { Federal }\end{array}$ & $\begin{array}{l}\text { The regulation regulates to what extent and in which cases the BVL levies } \\
\text { fees for official actions under the Genetic Engineering Act. }\end{array}$ \\
\hline
\end{tabular}

${ }^{3}$ Verordnung über Antrags- und Anmeldeunterlagen und über Genehmigungs- und Anmeldeverfahren nach dem Gentechnikgesetz (Gentechnik-Verfahrensverordnung - GenTVfV) ${ }^{4}$ Verordnung über die Zentrale Kommission für die Biologische Sicherheit (ZKBS-Verordnung - ZKBSV)

${ }^{5}$ Verordnung über die Sicherheitsstufen und Sicherheitsmaßnahmen bei gentechnischen Arbeiten in gentechnischen Anlagen (Gentechnik-Sicherheitsverordnung - GenTSV)

${ }^{6}$ Verordnung über Aufzeichnungen bei gentechnischen Arbeiten und bei Freisetzungen (Gentechnik-Aufzeichnungsverordnung - GenTAufzV) 


\begin{tabular}{|c|c|c|c|}
\hline echnology (BGenTGKostV7) & $\begin{array}{l}\text { amended } \\
\text { in 2013) }\end{array}$ & Gove & \\
\hline $\begin{array}{l}\text { Regulation on Participation of the Council, } \\
\text { the Commission and the Authorities of the } \\
\text { Member States of the European Union and } \\
\text { the other Contracting Parties to the } \\
\text { Agreement with the European Economic } \\
\text { Area in the Procedure for Authorization of } \\
\text { the Release and Marketing and Post- } \\
\text { clearance Measures under the Law on } \\
\text { Genetic Technology }\left(G e n T B e t V^{8}\right)\end{array}$ & $\begin{array}{l}\text { Since } \\
1995 \text { (last } \\
\text { amended } \\
\text { in 2006) }\end{array}$ & $\begin{array}{l}\text { Federal } \\
\text { Ministry of } \\
\text { Health (now } \\
\text { Federal } \\
\text { Ministry of } \\
\text { Agriculture) }\end{array}$ & $\begin{array}{l}\text { The Regulation contains rules on the participation of the Council, the } \\
\text { Commission and the authorities of the Member States of the European } \\
\text { Union and the other States Parties to the Agreement on the European } \\
\text { Economic Area in the authorization procedure for release and placing on } \\
\text { the market and in the procedure for subsequent action under the Genetic } \\
\text { Engineering Act. }\end{array}$ \\
\hline $\begin{array}{l}\text { Regulation on the Construction of Extra- } \\
\text { Professional Emergency Plans and the } \\
\text { Responsibilities in Information, Registering } \\
\text { and Educating (GenTNotfV }{ }^{9} \text { ) }\end{array}$ & $\begin{array}{l}\text { Since } \\
1997 \text { (last } \\
\text { amended } \\
\text { in 2008) }\end{array}$ & $\begin{array}{l}\text { German } \\
\text { Federal } \\
\text { Government }\end{array}$ & $\begin{array}{l}\text { The regulation regulates the point when the competent authority must } \\
\text { draw up an emergency plan. If an accident occurs, the operator must } \\
\text { immediately inform the competent authority according to the Regulation. } \\
\text { The authority shall then ensure that all necessary measures are taken. }\end{array}$ \\
\hline
\end{tabular}

7 Bundeskostenverordnung zum Gentechnikgesetz (BGenTGKostV)

${ }^{8}$ Verordnung über die Beteiligung des Rates, der Kommission und der Behörden der Mitgliedstaaten der Europäischen Union und der anderen Vertragsstaaten des Abkommens über den Europäischen Wirtschaftsraum im Verfahren zur Genehmigung von Freisetzungen und Inverkehrbringen sowie im Verfahren bei nachträglichen Maßnahmen nach dem Gentechnikgesetz (Gentechnik-Beteiligungsverordnung - GenTBetV)

${ }^{9}$ Verordnung über die Erstellung von außerbetrieblichen Notfallplänen und über Informations-, Melde- und Unterrichtungspflichten (Gentechnik-Notfallverordnung - GenTNotfV) 


\begin{tabular}{|c|c|c|c|}
\hline $\begin{array}{l}\text { Law on the Implementation of the } \\
\text { Regulations of the European Community or } \\
\text { the European Union in the Field of Genetic } \\
\text { Technology and on the Labeling of Food } \\
\text { Produced without the Use of Genetic } \\
\text { Technology (EGGenTDurchfG }{ }^{10} \text { ) }\end{array}$ & $\begin{array}{l}\text { Since } \\
2004 \text { (last } \\
\text { amended } \\
\text { in 2015) }\end{array}$ & $\begin{array}{l}\text { German } \\
\text { Federal } \\
\text { Government }\end{array}$ & $\begin{array}{l}\text { The law stipulates how the German domestic authorities shall implement } \\
\text { the EU GMO law. }\end{array}$ \\
\hline $\begin{array}{l}\text { Regulation on Good Practice in the } \\
\text { Production of Genetically Modified Plants } \\
\left(\text { GenTPflEV }{ }^{11}\right)\end{array}$ & $\begin{array}{l}\text { Since } \\
2008\end{array}$ & $\begin{array}{l}\text { German } \\
\text { Federal } \\
\text { Government }\end{array}$ & $\begin{array}{l}\text { The regulation provides rules of good practice for the cultivation of GM } \\
\text { plants. }\end{array}$ \\
\hline
\end{tabular}

${ }^{10}$ Gesetz zur Durchführung der Verordnungen der Europäischen Gemeinschaft oder der Europäischen Union auf dem Gebiet der Gentechnik und über die Kennzeichnung ohne Anwendung gentechnischer Verfahren hergestellter Lebensmittel (EG-Gentechnik-Durchführungsgesetz - EGGenTDurchfG)

${ }^{11}$ Verordnung über die gute fachliche Praxis bei der Erzeugung gentechnisch veränderter Pflanzen (Gentechnik-Pflanzenerzeugungsverordnung - GenTPflEV) 


\subsubsection{Basic Regulations of GMOs for General Use}

\subsection{The Regulation at the EU Level: Directive 2001/18/EC}

In order to approximate the GMO-related rules within the EU as well as ensure a high level of protection for human health and the environment when regulating GMOs related activities, Directive 2001/18/EC was enacted in 2001. It plays a significant role in directing the EU member states to establish a consistent GMO regulatory system within the EU. It mainly governs the deliberate release of GMOs into the environment and placing GMOs on the market as products or product components. Release and placing on the market of GMOs are mutually exclusive, both of which are subject to authorization. The concrete coverage of the authorization requirement for GMOs intended for release and marketing is determined by GMOs' definition. The primary purpose of the Directive is to protect human health and the environment (Art.1). Besides, the Directive 2001/18/EC embodies the precautionary principle to prevent significant adverse effects potentially caused by GMOs (Art.1(1), Art.4 (1), and recital 8).

Overall, the Directive consists of a long preamble, 38 Articles, and 8 Annexes. In the preamble, some essential requirements are laid down; for example, no GMOs can be released without authorization from the competent authority, the precautionary principle shall be respected, a risk assessment shall be conducted in the form of case-by-case. The provisions of the directive are divided into four parts, including general provisions (Art. 14), deliberate release of GMOs for any other purpose than for placing on the market (Art. 5-11), placing on the market of GMOs as or in products (Art. 12-14), and final provisions (Art. 25-38).

Section A (general provisions) outlines some special terms concerning GMOs in Art. 2, such as GMO and environmental risk assessment. The directive should not be neglected to cover only GMOs for general use other than food and feed. As regards the latter, to some extent, more strict provisions are laid down in Regulation 1829/2003. Besides, several general obligations for applicants and member states are provided. Also, Art. 4 lays down several general requirements for granting authorization, such as the precautionary principle and 
case-by-case risk assessment. It also obliges the member states to carry out inspection and precautionary measures on GMOs, which shall be appropriate and comply with the annex of this Directive.

Section B and Section C are the main contents of Directive 2001/18/EC, providing detailed requirements for deliberate release and placing GMOs on the market. Part B, entitled "Deliberate Release of GMOs for any other purpose than for placing on the market," lays down procedures for the release authorization of GMOs and supervision. ${ }^{1}$ Therefore, this section's regulatory object is the activities of "any intentional introduction into the environment" of GMOs excepting marketing. Part C, entitled "Placing on the market of the GMOs as or in products," provides procedures for authorizing the marketing of GMOs. The provisions for marketing are stricter than for regular release. Also, products placed on the market must be labelled (Art. 21). The marketing authorization is now limited to ten years (Art. 15(4)). More information about risk assessment, risk management, information to the public, and safety measures related to the Release and Marketing of GMOs will be presented in sections 6.3.

In the final section, further provisions concern additional requirements for labeling, confidentiality, cultivation and consultation of the committee, responsibilities of competent authorities, etc. Articles 28 and 29 set out individual consultation requirements relating to the European Food Safety Authority (EFSA) and the Committee on Ethics. Art. 30 prescribes the Committee procedure (or Comitology procedure) of the EU system, which applies when, due to disagreement among the member states on dealing with an application, the decision is taken at the EU level. The procedure is laid down in Regulation No 182/2011. In the directive, a scientific risk assessment is at the center of the procedure: every authorization for placing a product on the market must be duly justified, and the main ground on which such a justification can rest is scientific assessment. In addition, the Directive also lays down the approach of risk communication, that is, acquiring more information relating to GMO risks through public registers and the involvement of the public in the authorization process.

${ }^{1}$ The basic competences for applying national law implementing the directive are vested in the member states. 
Directive 2001/18/EC has been amended many times. Two consequential amendments must be mentioned: Regulation (EC) No 1829/2003 and Directive 2015/412. At first, Regulation (EC) No 1829/2003 adopted in 2003 stipulates special rules for GMOs for food and feed use, which supersedes Directive 2001/18/EC relating to food and feed. Afterward, because of the vastly different attitudes towards GMOs among the member states, the EU has relaxed the harmonization requirements on GMO cultivation to some extent through Directive 2015/412. It allows that individual EU countries, in the authorization procedure, can "optout" of cultivation in their territory (Art. 26b (1) and (2) or can afterward ban or restrict the cultivation of permitted GM crops in their territory, in the latter case only for specific reasons (Art. 26b (3)), such as environmental policy, socio-economic impacts, etc. However, the national prohibition shall conform to EU law and be reasoned, proportional, and nondiscriminatory (Art. 26b (3)). In addition, for the first time, the element of socio-economic impacts were incorporated into the GMO law in the EU (Art. 26b (3) d).

\subsection{The Regulation at the German Domestic Level: Gentechnikgesetz}

The Law on Genetic Technology (Gentechnikgesetz - GenTG) is the fundamental German law regarding genetic technology. It assumes the role of implementing the relevant EU Directives, such as Directive 2001/18/EC. It contains the most crucial rules on questions of (green) GMOs. It is designed to protect against the risks of genetic technology on human health and the environment (Art. 1(1)), enable the coexistence of GMOs and GM-free products (Art. 1(2)), and standardize research and use of it (Art. 1(3)). It appears that neither the protection of personal freedom to an established and exercised business nor a mandate for the competent authority to promote technological genetic research is explicitly provided in Art. $1 .^{2}$ Its regulatory scope covers activities of contained use, releasing, and marketing of GMOs and products containing or consisting of it (Art. 2). The application of genetic technology in humans is excluded.

The provisions of the Gentechnikgesetz are the expression of a comprehensive

2 Kauch, Gentechnikrecht, 2009, p. 68. 
precautionary principle (Art. 1 No 1, 6 and $16(1)$ ), which is a response to uncertainties and deficits in knowledge about GMOs and, therefore, allows to pursue scientific and technical development only step by step ${ }^{3}$ and - if necessary - comprehensively control it. ${ }^{4}$ The intensity of the controls varies according to the risk associated with the activity. The risks to humans and the environment must be scientifically assessed. Another important principle embodied in the Gentechnikgesetz is coexistence (Art. 1 no 2), which is mentioned in Art. 26a of Directive 2001/18/EC. For example, there are duties of care oriented towards the coexistence of production forms, which are provided in Art. 26b (1a, but coexistence is not a prerequisite for authorization.

Overall, the Gentechnikgesetz consists of 42 provisions. It is divided into seven sections, namely, General rules (Art. 1- 6), genetic engineering works in genetic engineering facilities (Art. 7 -12), release, and placing on the market (Art. 7-16e), common rules (Art. 17-31), liability (Art. 32-37), penalties, and fines (Art. 38-39), and transitional and final provisions(Art. 41-42).

The first part of the Gentechnikgesetz contains general rules. It includes the purpose of the law, the scope of application, and the basic definitions. Besides, Art. 4 provides the constitution and responsibility of the Central Commission for Biological Safety (Kommission für die Biologische Sicherheit, hereafter ZKBS), whose function role is similar to the European Food Safety Agency. This institute is responsible for providing scientific expertise and monitoring official decisions. ${ }^{5}$ What should be particularly mentioned is that Art. 6 provides general obligations relating to duties of care, risk assessment, danger precaution, keeping records, and appointing expert personnel, which must be observed by the operator and other responsible persons of genetic engineering facilities. These are not static but dynamic obligations adapting to the state of development and knowledge. This means that there is no one-size-fits-all protection measure against GMO risk, and the operator is responsible for updating the information and adjusting the precautionary

\footnotetext{
3 Wahl, Kommentar zum Gentechnikgesetz, in: Landmann \& Rohmer (eds.), Umweltrecht Vol. II, 1994, § 1 No 65 et seq.

${ }^{4}$ Wahl \& Appel, Prävention und Vorsorge: Von der Staatsaufgabe zur rechtlichen Ausgestaltung, in: Wahl \& Appel (eds.), Prävention und Vorsorge, 1995, p. 108.

${ }^{5}$ Schubert, Zwanzig Jahre Gentechnikgesetz - eine Erfolgsgeschichte?, NVwZ 2010, p. 873.
} 
measures according to the state of the art of science and technology.

Section 2 applies to contained use. Contained use is regulated in the manner of controlling genetic engineering facilities engaging in genetic engineering works, which is a kind of measure contributing to control risks at the source. Every genetic technological project or facility is subject to a precautionary control in the form of gradually increasing control intensity according to the risk potential existing in the individual works. ${ }^{6}$ Art. 7 provides that the operator is obliged to conduct a risk assessment and then classify the relevant genetic engineering works into four different levels according to the risk potential for human health and the environment. ${ }^{7}$ It determines the further handling and the precautionary requirements for the related activities. Each of these security levels is linked to a differentiated extent of binding security and approval requirements. Notwithstanding that most genetic engineering work can be assigned to the lowest safety level, the risk must be assessed on a case-by-case basis. The specific classifying standards are specified in the GenTSV.

Section 3 sets out the requirements for the decision-making process of releasing and placing on the market of GMOs, entitled "section 3 releasing and placing on the market" (Freisetzung und Inverkehrbringen). Every release and marketing of GMOs are subject to an authorization requirement (Art. 14 (1) of GenTG). A uniform standard procedure would not do justice to the broad spectrum of risks; therefore, differentiated procedures for contained use, release, and marketing exist. The authorization of releases and marketing also requires an assessment of the potential risk. ${ }^{8}$ The conditions for approval are regulated in Art. 16 (1) and (2) of GenTG. More information about the release and marketing of GMOs will be presented in Section 5.3.

Other common rules, such as confidentiality of information (Art. 17a), labeling (Art. 17b), procedures for the consultation of the public (Art. 18), delegation to the executive in the

\footnotetext{
${ }^{6}$ Wahl \& Appel, Prävention und Vorsorge: Von der Staatsaufgabe zur rechtlichen Ausgestaltung, in: Wahl \& Appel (eds.), Prävention und Vorsorge, 1995, p. 108.

${ }^{7}$ Pottschmidt, Gentechnikrecht, in: Rehbinder \& Schink (eds.), Grundzüge des Umweltrechts (5th edition), 2018, p. 1153.

${ }^{8}$ Wahl \& Appel, Prävention und Vorsorge: Von der Staatsaufgabe zur rechtlichen Ausgestaltung, in: Wahl \& Appel (eds.), Prävention und Vorsorge, 1995, p. 108.
} 
form of regulations and administrative rules (Art. 30), as well as ancillary provisions and subsequent conditions (Art. 19), are concretized in section 4. In particular, the law provides powers which the competent authorities can exercise in the context of their supervisory functions, such as temporary suspension (Art. 20) and monitoring (Art. 25). The expiry of the authorization, or the invalidity of the application, are also standardized here. Finally, liability, penalties, and fines for violations are laid down in sections 5 and 6, respectively. Among them, strict liability is provided. ${ }^{9}$

6.1.1.2 Basic Regulation of GMOs for Food and Feed Use: Regulation (EC) No 1829/2003

In order to further unify the EU internal market and to protect human life and health, animal health and welfare, environment and consumer interests (Art. 1), Regulation (EC) $1829 / 2003$ was enacted regulating the placing on the market of GMOs for food and feed (Art. 2 (14)). GM food and feed refer to products containing, consisting of, or being produced from GMOs, or ingredients being produced from GMOs. The Regulation also covers GMOs for other uses, such as cultivation, if they are to be used as source material for food and feed production. ${ }^{10}$ As a special law on GM food and feed, it takes precedence over Directive 2001/18/EC, Regulation 178/2002, the regulation on general food law as well as Gentechnikgesetz (Art. 4(5) of Regulation (EC) No. 1829/2003). Meanwhile, any other GMOs and material derived from GMOs not for food and feed use is not covered by this norm but can be subject to Directive 2001/18. Being a regulation, Regulation 1829/2003 is directly applicable in all member states without the need for national transposition. ${ }^{11}$

Overall, the regulation includes four chapters and one Annex, namely, objective and definitions (Art. 1-2), genetically modified food (Art. 3-14), genetically modified feed (Art. 15-26), and common provisions (Art. 27-49). The regulation provides mainly the procedure for authorization, supervision, and labeling of GM food and feed.

\footnotetext{
${ }^{9}$ Schubert, Zwanzig Jahre Gentechnikgesetz - eine Erfolgsgeschichte? NVwZ 2010, p. 873.

${ }^{10}$ European Commission, Reviewing the decision-making process on genetically modified organisms (GMOs), 2015. See: https://ec.europa.eu/commission/presscorner/detail/en/MEMO_15_4779

${ }^{11}$ Pottschmidt, Gentechnikrecht, in: Rehbinder \& Schink (eds.), Grundzüge des Umweltrechts (5th edition), 2018, p. 1156.
} 
Specifically, the regulation has formulated several control measures: authorization, labeling, environmental risk assessment, etc. The precautionary principle and a public right to know are also laid down in this regulation. The first section of the regulation clarifies the legislative objectives and relevant definitions. In the second section, GM food is regulated. In the third section, the rules for genetically modified feeds are set out in a way that is almost consistent with those applicable to foods, although with several minor differences between them. In these two sections, provisions for genetically modified foods and feed have been laid down, including the application for authorization, risk assessment and expert opinion from EFSA, decision-making in the EU, supervising, etc. Marketing of GM food and feed is subject to an authorization. Therefore, the applicant shall submit qualified documents according to the Regulation, whereby the risk assessment is crucial. The detailed operation of the authorization procedure will be presented in sections 3.3 and 3.4. Besides, labeling provisions for genetically modified food and feed are laid down (Art. 12 to 14 and 24 to 26 of the Regulation). If the proportion of genetically modified material does not exceed 0.9 percent of the individual food ingredients or feed or feed components, labeling is not required; otherwise, labeling is mandatory. The consideration of the proportion is adventitious and technically unavoidable. In the fifth part of this regulation, the registration system for GM foods and an EU laboratory inspection system has been set up. Further provisions concern the ethics committee's consultation, emergency assistance, the use of comitology, and so on. In the end, the penalties and redress for violation of this law's provisions belong to the member states' jurisdiction.

Regulation (EC) No 1829/2003 has also been amended several times. A recent amendment that needs to be highlighted is the Regulation (EU) 2019/1381 on transparency and sustainability of the EU risk assessment. This amendment took place against the backdrop of "public controversy over the approach towards the assessment and management of sensitive substances such as genetically modified organisms"12, and that the integrity, validity, and reliability of science are challenged. ${ }^{13}$ More specifically, citizens and/or stakeholders criticized the lack of transparency in the risk assessment process in the area of

${ }^{12} \operatorname{COM}(2018) 179$ final

See: https://eur-lex.europa.eu/legal-content/EN/TXT/?uri=COM\%3A2018\%3A0179\%3AFIN\#footnoteref25

${ }^{13}$ Edwards \& Roy, Academic Research in the 21st Century: Maintaining Scientific Integrity in a Climate of Perverse Incentives and Hyper Competition, Environmental Engineering Science Vol. 34 (2017), p. 51, 56. 
food law, argued that EFSA's evaluations of authorization applications should not be based solely on information from applicants, and complained that risk communication was not effective, etc. Through Fitness Check of food laws and current public debates, the European Commission has perceived a lot of problems in food laws, for instance, a "lack of transparency of the risk analysis process", risk communication creating "a negative impact on consumers' confidence and on the acceptability of risk management decisions", existing "limitations in EFSA's capacity to ensure in the long-term sufficient expertise", and so on. ${ }^{14}$ As a result, the European Commission has proposed a Proposal to amend a number of food laws, including Regulation (EC) No 1829/2003. The novel legal practice focuses on two intertwined topics: what is role can science play in the legal or policy decision process and what are the suitable procedural approaches that a knowledge-based society can deploy to deal with current scientific issues. ${ }^{15}$ Specifically, the final adopted amendment, i.e., Regulation (EU) 2019/1381, aims to improve transparency rules underpinning risk assessment, increase the independence, reliability, and robustness of submitted scientific studies, strengthen governance and scientific cooperation to involving member states in the evaluation process, and develop a comprehensive and transparent risk communication. Regulation (EU) 2019/1381 mainly amended the general regulation on food and feed, namely Regulation (EC) No 178/2002. Specifically, it added more detailed rules on risk communication, consultation of third parties, protection of confidentiality, and personal data, which brings significant innovations to the institutional architecture on food safety. ${ }^{16}$ Moreover, it also amended Regulation (EC) No $1829 / 2003$ by requiring that in the framework of Regulation (EC) No 1829/2003 some amended provisions of Regulation (EC) No $178 / 2002$ need to be respected. That is to say, Regulation (EU) 2019/1381 indirectly modified the GMO food law by amending the provisions of general food law in the areas of risk communication and risk assessment.

\footnotetext{
${ }^{14}$ COM (2018) 179 final

See: https://eur-lex.europa.eu/legal-content/EN/TXT/?uri=COM\%3A2018\%3A0179\%3AFIN\#footnoteref25

${ }^{15}$ Leone, EFSA under Revision: Transparency and Sustainability in the Food Chain, Yearbook of European Law, Vol. 39 No. 1 (2020), p. 537.

${ }^{16}$ Leone, EFSA under Revision: Transparency and Sustainability in the Food Chain, Yearbook of European Law, Vol. 39 No. 1 (2020), p. 538.
} 


\subsubsection{China}

Since the first transgenic plant-Bt tobacco was commercialized in China's 1990s, the Chinese government is increasingly investing in new GM technology research and development. ${ }^{17}$ It has targeted agricultural biotechnology as an area of national strategic scientific investment. Chinese authorities are keen for the country to enter the forefront of GM technology; meanwhile, the Chinese public is deeply suspicious about the safety of genetic technology. ${ }^{18}$ Thus, on the one hand, the Chinese government is very eager to promote the development of science and technology and, on the other, has to devote considerable attention to and accommodate public opposition. Until now, of all agricultural species, only GMO corn and papaya have been approved for commercial planting in China, while some GMO plants, such as soybean and corn, are only allowed to be exported to China as material for food processing.

In the face of a conflict of values arising from or relating to GM technology, such as rural development vs. agricultural modernization, economic growth vs. environmental degradation, comprehensive legislation concerning GMOs has been adopted to establish a 'good governance' on GMOs. ${ }^{19}$ Of course, the actual effects do not always follow the expected targets. This section will present the regulatory framework in China concerning GMOs and selectively interpret some legal provisions directly relating to GMO authorization.

In China, the first rule for GMOs was the Administrative Regulation on Safety of Genetic Technology issued in 1993 by the Chinese Ministry of Science and Technology, repealed by subsequent regulation..$^{20}$ The presently valid regulatory framework on green GMOs is

\footnotetext{
${ }^{17}$ Huang \& Wang, Agricultural Biotechnology Development and Policy in China, Journal of Agrobiotechnology Management \& Economics Vol.5: 4 (2002), p. 125; Zhang, China: Agricultural Biotechnology Opportunities to Meet the Challenges of Food Production, in Persley, \& Lantir, (eds.), Agricultural Biotechnology and the Poor, Washington, D. C., Consultative Group on International Agricultural Research 1999, p. 46.

${ }^{18}$ Experimental Chinese GM rice strain wins landmark US approval. But it is still banned in China

See: $\quad$ http://www.scmp.com/news/china/society/Art./2130066/experimental-chinese-gm-rice-strain-winslandmark-us-approval-its

${ }^{19}$ Xiang Wen, Risk Governance of GMOs in the EU and in China, Ghent University, 2013, p. 191. See: https://biblio.ugent.be/publication/3160785

${ }^{20}$ Chen, Shelton, \& Ye, Insect-resistant genetically modified rice in China from research to commercialisation, The Annual Review of Entomology (2011), p. 81.
} 
constituted in the form of one "core" regulation ${ }^{21}$, and several implementing regulations ${ }^{22}$," i.e., Regulation on Management of Safety of Agricultural GMOs (RSAGMO regulation) issued in 2001 by the State Council of China as the essential core rule, several implementing administrative regulations as supplementing and concretizing rules.

The Regulation on Management of Safety of Agricultural GMOs contains detailed prescriptions for laboratory research, biosafety testing, production, processing, marketing, and import and export activities concerning agricultural GMOs. ${ }^{23}$ Following the State Council Regulations, the Agricultural Authority in 2002 announced three implementing measures ${ }^{24}$, precisely, on labeling, evaluation, and import; later, in 2006, a measure for the licensing system for processing agricultural GMOs. The Forestry Authority has formulated a particular regulation regulating forest-related GMOs, and Customs also has provided a special regulation for inspection and quarantine of imported GMOs.

As for GM food safety, in 2002, the Ministry of Public Health ${ }^{25}$ promulgated the regulation on GMO food hygiene. This regulation collectively covered all aspects of GMOs, including laboratory research, food and environmental safety testing, labeling, production, processing, marketing, and import and export of GMOs and GMO-derived products ${ }^{26}$, thereby providing the basic rule for promoting the sustainability of agricultural biotechnology in China. ${ }^{27}$ The Regulation on GMO food hygiene was a special regulation on GMO-related to food hygiene, which was unfortunately repealed by a general food regulation in 2007, namely, the Regulation for Management of New Food Resources, in which there are no special provisions for GMOs. The Regulation for Management of New Food Resources only indicated that the management of GM foods and food additives should be carried out in

\footnotetext{
${ }^{21}$ In China's legislative system, a regulation is a kind of law that is promulgated by the State Council of China under the authority of the Constitution, which is valid throughout the country and whose hierarchical legal force is only second to law promulgated by the National People's Congress of China.

${ }^{22}$ In China's legislative system, an administrative regulation is a kind of law that is issued by various ministries under the authority of the Constitution, which is also valid throughout the country and whose hierarchical legal force is next to law promulgated by the National People's Congress of China, regulation promulgated by State Council of China.

${ }^{23} \mathrm{Li}$, et al., The development and status of Bt rice in China, Plant Biotechnology Journal Vol. 14 (2016), p. 839.

${ }^{24} \mathrm{Li}$, et al., The development and status of Bt rice in China, Plant Biotechnology Journal Vol. 14 (2016), p. 839.

${ }^{25}$ Now named National Health Commission.

${ }^{26}$ Yang, Regulation of GMOs in China, Review of European Community and International Environmental Law Vol. 12: 1 (2003), p. 99.

${ }^{27} \mathrm{Li}$, et al. The development and status of Bt rice in China. Plant Biotechnology Journal Vol. 14 (2016), p. 839.
} 
accordance with relevant national laws and regulations (Art. 27). ${ }^{28}$ However, no other alternative legislation regarding GM food has been passed so far. In 2015, the Law on Food Safety had added three articles concerning GM food. First, Art. 69 clarifies that GMO foods products shall be clearly labeled ${ }^{29}$; second, the food and drug authority is in charge of punishing the illegal behavior of not labeling GMOs properly (Art. 125); third, Art. 151 provides that the provisions of other relevant laws and administrative regulations shall apply to GM food insofar as there are no specific rules in this Law. There are only two practically applicable articles in this food law, which is hard to say can guarantee the safety of GM food. At the same time, there are several other laws relating to GMOs, such as the Fisheries Law of China, Agriculture Law of China, Seed Law of China, and Food Safety Law of China, but they will not be explained in this dissertation since they have not formulated detailed regulations for GMOs. The table below enumerates a more detailed list of rules relating to adopted by China.

\footnotetext{
${ }^{28}$ Chen, Shelton \& Ye, Insect-resistant genetically modified rice in China from research to commercialization, The Annual Review of Entomology (2011), p. 81.

${ }^{29}$ Given the circumstance that agricultural GMOs are planted in a specified area, the area should be marked, in order to inform the population in the surroundings.
} 
Overview of the Regulations on GMOs and GM Foods in China

\begin{tabular}{|c|c|c|c|}
\hline Name of regulations & Validity period & Promulgation department & The content relating to GMOs \\
\hline $\begin{array}{l}\text { Administrative Regulation on Safety } \\
\text { of Genetic Technology }\end{array}$ & $1993-2000$ & $\begin{array}{l}\text { Ministry of Science and } \\
\text { Technology }\end{array}$ & $\begin{array}{l}\text { It is a special administrative regulation for the safety } \\
\text { management of GMOs. Mainly govern genetic research. }\end{array}$ \\
\hline $\begin{array}{l}\text { Regulation on Management of } \\
\text { Safety of Agricultural GMOs } \\
\text { (hereafter as RMS-AGMO) }\end{array}$ & $\begin{array}{l}\text { 2000- } \\
\text { (Revised in } \\
2011,2017)\end{array}$ & State Council & $\begin{array}{l}\text { It is the legislation regulating agricultural GMOs and the } \\
\text { most important legislation for GMO safety management in } \\
\text { China. }\end{array}$ \\
\hline $\begin{array}{l}\text { Administrative Regulation for the } \\
\text { Management of the Safety } \\
\text { Assessment of Agricultural GMOs } \\
\text { (hereafter as ARMSA-AGMO) }\end{array}$ & $\begin{array}{l}\text { 2002- } \\
\text { (Revised in } \\
2004, \quad 2016, \\
2017)\end{array}$ & $\begin{array}{l}\text { Ministry of Agriculture } \\
\text { (Now named Ministry of } \\
\text { Agriculture and Rural } \\
\text { Affairs, hereinafter MoA) }\end{array}$ & $\begin{array}{l}\text { It is an implementing regulation for agricultural GMO safety } \\
\text { evaluation management programs and standards. }\end{array}$ \\
\hline $\begin{array}{l}\text { Administrative Regulation for the } \\
\text { Management of the Safe Import of } \\
\text { Agricultural GMOs (hereafter as } \\
\text { ARMSI-AGMO) }\end{array}$ & $\begin{array}{l}\text { 2002- } \\
\text { (Revised in 2004, } \\
\text { 2017) }\end{array}$ & MoA & $\begin{array}{l}\text { It is an implementing regulation for imported agricultural } \\
\text { GMOs' management }\end{array}$ \\
\hline $\begin{array}{l}\text { Administrative Regulation for the } \\
\text { Management of the Label of } \\
\text { Agricultural GMOs (hereafter as }\end{array}$ & $\begin{array}{l}\text { 2002- } \\
\text { (Revised in 2004, } \\
\text { 2017) }\end{array}$ & MoA & $\begin{array}{l}\text { It is an implementing regulation for label agricultural GMOs' } \\
\text { management }\end{array}$ \\
\hline
\end{tabular}




\begin{tabular}{|c|c|c|c|}
\hline ARML-AGMO) & & & \\
\hline $\begin{array}{l}\text { Administrative Regulation for the } \\
\text { Management on the Inspection and } \\
\text { Quarantine of Entering and Exiting } \\
\text { the Territory of the GM Products } \\
\text { (hereafter as ARMIQEE-AGM } \\
\text { Products) }\end{array}$ & $\begin{array}{l}\text { 2004-(Revised in } \\
\text { 2018) }\end{array}$ & $\begin{array}{l}\text { Bureau of Quality } \\
\text { Supervision, Inspection, and } \\
\text { Quarantine (Revoked and } \\
\text { Customs undertake the } \\
\text { related responsibility) }\end{array}$ & $\begin{array}{l}\text { It is an implementing regulation for inspection and } \\
\text { quarantine system of entry and exit for GM products }\end{array}$ \\
\hline $\begin{array}{l}\text { Administrative Regulation of } \\
\text { Management of Examining and } \\
\text { Approving Methods for Genetic } \\
\text { Engineering Activities of Forest } \\
\text { (hereafter as ARMEA-GMF) }\end{array}$ & $\begin{array}{l}\text { 2006- ( Revised } \\
\text { in 2018) }\end{array}$ & $\begin{array}{l}\text { Bureau of Forestry (now } \\
\text { named Bureau of Forestry } \\
\text { and Grassland, hereafter as } \\
\text { BoFG) }\end{array}$ & It is a special regulatic \\
\hline $\begin{array}{l}\text { Administrative Regulation for the } \\
\text { Examination and Authorization of } \\
\text { Processing of Agricultural GMOs } \\
\text { (hereafter as AREAP-AGMO) }\end{array}$ & $2006-$ & MoA & $\begin{array}{l}\text { It regulates the further processing of agricultural GMOs. } \\
\text { Further processing refers to manufacturing agricultural } \\
\text { GMO products from living agricultural GMOs as raw } \\
\text { materials, such as pesticides, veterinary drugs, fertilizers, } \\
\text { additives (Art. } 2 \text { of AREAP-AGMO) }\end{array}$ \\
\hline Fisheries Law of the People's & 1986-(revised in & Standing Committee of & Art. 17 provided that the safety of imported GM aquatic \\
\hline
\end{tabular}




\begin{tabular}{|c|c|c|c|}
\hline Republic of China & $\begin{array}{l}\text { 2000, 2004, } \\
\text { 2013) }\end{array}$ & Congress & fingerlings must be assessed. \\
\hline $\begin{array}{l}\text { Agriculture Law of the People's } \\
\text { Republic of China }\end{array}$ & $\begin{array}{l}\text { 1993- } \\
\text { (Revised in 2002, } \\
2009,2012)\end{array}$ & $\begin{array}{l}\text { Standing Committee of } \\
\text { Congress }\end{array}$ & $\begin{array}{l}\text { A provision in this law prescribes that the research, testing, } \\
\text { and production of agricultural GMOs shall strictly comply } \\
\text { with international regulations. }\end{array}$ \\
\hline $\begin{array}{l}\text { Seed Law of the People's Republic of } \\
\text { China }\end{array}$ & $\begin{array}{l}\text { 2000-(Revised in } \\
2004, \quad 2013, \\
2015)\end{array}$ & $\begin{array}{l}\text { Standing Committee of } \\
\text { Congress }\end{array}$ & $\begin{array}{l}\text { Art. } 7 \text { provides that variety selection, cultivation, } \\
\text { experiments, approval, and promotion of GM plant varieties } \\
\text { shall be subject to safety assessment, and strict safety control } \\
\text { measures shall be taken. } \\
\text { Art. } 41 \text { provides that, for the sale of seeds of GM plant } \\
\text { varieties, readable labeling is essential, and safety control } \\
\text { measures shall be indicated for their use. }\end{array}$ \\
\hline $\begin{array}{l}\text { Animal Husbandry Law of the } \\
\text { People's Republic of China }\end{array}$ & $\begin{array}{l}2005-(2015 \\
\text { revised })\end{array}$ & $\begin{array}{l}\text { Standing Committee of } \\
\text { Congress }\end{array}$ & $\begin{array}{l}\text { Art. } 20 \text { of this law provides that breeding, experiments, } \\
\text { examination, approval, and promotion of genetic-modified } \\
\text { livestock and poultry species shall be in line with the } \\
\text { relevant law and regulation. }\end{array}$ \\
\hline Biosafety Law & 2021 & Committee of Congress & $\begin{array}{l}\text { This law is a comprehensive law, which provides several } \\
\text { rules concerning research on biotechnology. }\end{array}$ \\
\hline
\end{tabular}




\subsubsection{Regulation on Management of Safety of Agricultural GMOs}

The Regulation on Management of Safety of Agricultural GMOs (RMS-AGMO) was issued in 2000 by the State Council to strengthen the safety management of agricultural genetically modified organisms (GMOs), safeguard human health and the safety of animals, plants, and microorganisms, protect the ecological environment, and promote research in agricultural GMO technology (Art. 1). Having by far the highest hierarchical legal effect and most comprehensive contents among the special rules regulating GMOs, it is the principal and most crucial norm for agricultural GMOs in China. It regulates research, experiments, production, processing, marketing, import, and export of agricultural GMOs in China (RASAGMO: Art. 2). ${ }^{1}$ Overall, there are 8 Chapters provided in the RAS-AGMO, namely general rules (Art. 1- 8), research and testing (Art. 9- 18), production, and further processing ${ }^{2}$ (Art. 19- 24), marketing (Art. 25- 29), importation and exportation (Art. 30-37), supervision and inspection (Art. 38-41), punishment of violations (Art. 42-53), validity date (Art. 54).

In the first section, the concept of agricultural GMOs and the biosafety of agricultural GMOs are identified (Art. 3). Agricultural GMOs refer to the animals, plants, microorganisms whose genome composition has been altered by genetic engineering technology and is used for agricultural production or further processing and their related products (Art. 3 of RMS-AGMO). Specifically, the law covers (1) GM plants and animals (including seeds, breeding stock, aquatic seedlings) and micro-organisms; (2) yields of GM animal, plant, and microbial organisms; (3) products made from yields of GM animal, plant, and microbial organisms; (4) seeds, breeding stock, aquatic seedlings, pesticides, veterinary drugs, fertilizers, and additives containing GM plants, animals, microorganisms or their components.

It is worth underlining that "risk" appears only once in the RAS-AGMO, which is in Art. 3 where the concept of "biosafety" is identified: "Biosafety of Agricultural GMO refers to the

\footnotetext{
${ }^{1}$ RAS-AGMO: Art. 2 The activities of research, test, production, processing, marketing, import and export with respect to agricultural GMOs within the territory of the People's Republic of China must conform to these Regulations.

2 Further processing refers to manufacturing agricultural GMO products from living agricultural GMOs as raw materials, such as pesticides, veterinary drugs, fertilizers, additives (Art. 2 of AREAP-AGMO)
} 
prevention of dangers or potential risks posed by agricultural GMOs to humans, plants, animals, microorganisms and the ecological environment." Except for that, only the word "danger" is employed to describe the undesired consequences of GMOs in other provisions. In fact, there is no systematic theory in China to distinguish between danger, risk, or potential risk, so that an examination in the language of the legislation does not render an accurate description of for the administrative implementation. An Inter-Ministerial Joint Meeting ${ }^{3}$ is established for managing agricultural GMOs safety. It is composed of personnel from the ministries of agriculture, science, and technology, environmental protection, health, foreign trade, inspection and quarantine, etc. The Meeting is responsible for discussing and coordinating significant issues in managing agricultural GMO safety (Art. 5). For the sake of biosafety, Art. 6, 7, and 8 set out three main strategies for the governance concerning GMOs, namely a four-level - safety graduation and differentiated management ${ }^{4}$, labelling ${ }^{5}$, and safety assessment ${ }^{6}$. However, the three Articles do not contain specific requirements but merely state that the Ministry of Agriculture and Rural Affairs shall set the appropriate implementation standards. In conjunction with the Administrative Regulation for the Management of the Safety Assessment of Agricultural GMOs (Art. 9 of ARMSA-AGMO), agricultural GMOs are classified into four levels: I, II, III, and IV, on the basis of the extent of GMO danger to human beings, animals, plants, microorganisms, and the ecological environment. Level I means no danger yet; Level II refers to low danger; Level III stands for moderately dangerous; Level IV means highly dangerous. The four-level system in China is different from the four-level safety system in the German GenTG since the direct object of classification is GMOs in China, while, in Germany, its object is works with GMOs.

In section 2 of the Regulation, the Safety Committee for Agricultural GMOs is set up, responsible for the safety assessment of agricultural GMOs (Art. 9). It is composed of experts

\footnotetext{
${ }^{3}$ It is composed of responsible persons from the departments of agriculture, science and technology, environmental protection, public health, foreign trade and economic cooperation, inspection and quarantine, and from other relevant departments as well.

${ }^{4}$ More information is provided in the Administrative Regulation for the Management of the Safety Assessment of Agricultural GMOs (ARMSA-AGMO)

${ }^{5}$ More information is provided in Administrative Regulation for the Management of the Label of Agricultural GMOs (ARML-AGMO)

${ }^{6}$ More information is provided in Art. 16 and 17 of RAS-AGMO as well as Administrative Regulation for the Management of the Safety Assessment of Agricultural GMOs (ARMSA-AGMO)
} 
engaged in biological research, production, processing, inspection, and quarantine relating to agricultural GMOs as well as in public health and environmental protection. According to Art. 11 of RMS-AGMO, anyone engaged in agricultural GMO research and testing shall set up safety facilities and measures appropriate to the relevant GMO safety level to ensure safety. Unlike German requirements, the company or organization is not obliged to apply for an authorization of safety facilities from the administrative authority. Pursuant to Art. 13, every GMO shall be tested in three different phases in succession, i.e., Restricted fieldtesting, Enlarged field-testing, and Productive testing. Differentiated requirements of management for each stage are laid down in Articles 14, 15, and 16. In the three-stage testing system, only when the applicants are granted the Biosafety Certification issued by the authority can they move to the following stages (Art. 17), such as cultivation, marketing, or further processing. Of course, when the applicant engages in his next activity, other relevant laws have to be respected. A GM seed, for example, is also subject to the Seed Law of China. More information regarding the Safety Certification will be presented in section 6.2.2.

Section 3 regulates the production and further processing of GMOs. It primarily provides the obligations of registration (Art. 20 and 21), reporting (Art. 22 and 23), and compliance with security measures (Art. 24) applicable to a company or individual engaging in producing and further processing of GMO products. As for GMO marketing, section 4 generally obliges the company or individual who sells GMO products to register to the competent authority, label GMO-related products for sale, and take appropriate safety measures. Section 5 deals with importation and exportation, and section 6 concerns the responsibility of supervision and inspection by the competent authority. Punishments for a violation of the regulation are provided in section 7 .

\subsubsection{Implementing Administrative Regulations}

\subsection{ARMSA-AGMO}

The Administrative Regulation for the Management of the Safety Assessment of Agricultural GMOs (ARMSA-AGMO) is an important technical supplement to the RAS- 
AGMO instructing the relevant actors on how to conduct the agricultural GMOs' safety assessment and determination of the safety level, especially the procedure and required documents. It was laid down in 2002 by the agricultural authority, i.e., the Ministry of Agriculture and Rural Affairs. The Safety Committee for Agricultural GMOs is in charge of conducting the safety assessment. There are also 7 sections in this rule: general rules (Art. 1-8); safety levels and safety assessment (Art. 9-14); application and approval (Art. 15-27); technical testing management (Art. 28-30); supervision, management, and safety monitoring (Art. 31-38); penalty provisions (Art. 39-43); supplemental provisions (Art. 4446). Since the safety assessment is a crucial procedure of GMO authorization, it will be introduced in more detail in Section 6.3.2.2.

\subsection{ARML-AGMO}

The Administrative Regulation for the Management of the Label of Agricultural GMOs (ARML-AGMO) was formulated to strengthen the labeling management of agricultural GMOs, regulate the sales behavior with respect to agricultural GMOs, guide the production and consumption of agricultural GMOs, and protect the consumers' right to know. The labeling method, form, and range are clarified in this measure. The agricultural authority is empowered to govern the labeling of GMOs.

In 2017, the State Council published a political decision that pointed out that the Agriculture Authority shall strengthen and strictly control the agricultural GMO authorization. The agricultural authority shall strengthen the supervision and inspection of the label of agricultural GMOs by carrying out random sampling, setting up a reporting platform, and establishing a blacklist system. The information of the companies who violate labeling rules should be published in a "black-list" online. Although this is only a State Council policy, it has a robust guiding effect on the ministry.

\subsection{AREAP-AGMO}

The Administrative Regulation for the Examination and Approval of Processing of 
Agricultural GMOs (AREAP-AGMO) mainly regulates the examination and approval of the activity of further processing of agricultural GMOs. The in-depth process is generally based on the raw materials of active agricultural GMOs. The provincial agricultural authority is in charge of granting the authorization for further processing. Additionally, the provincial authority shall set up a GMO expert group for consultation.

\subsection{ARMSI-AGMO}

The Administrative Regulation for the Management of the Safe Import of Agricultural GMOs (ARMSI-AGMO) is a supplementing norm for the safety control of the import of agricultural GMOs. The management methods relating to imported GMOs are separated into three categories by the purpose of the import, namely, for research and testing, for production, and for further processing. All these three import objectives are subject to the requirement of an authorization. There are diverse requirements for each designed use of GMO, which will be explained later in section 6.3.2.2.5.

\subsection{ARMIQEE-GM Products}

The Bureau of Quality Supervision issued an Administrative Regulation for the Management of the Inspection and Quarantine of Entering and Exiting from the Territory by GM Products (ARMIQEE-GM Products). The Bureau of Quality Supervision has now been abolished, and Customs has assumed its whole responsibility. The Regulation mainly governs the inspection and quarantine on GM products entering and exiting from the territory of China through various ways (including trade, processing customer's materials, mailing, carrying, production, reproduction for others, scientific research, exchange, exhibition, aid, and donation, and other ways). Customs now is the competent authority in charge of the inspection (Art. 4).

\subsection{ARMEA-GMF}

Based on the distribution of competencies among Chinese ministries, wherein general 
agricultural affairs fall into the scope of the Ministry of Agriculture and Rural Affairs (MoA), and forestry affairs into the purview of the Bureau of Forestry and Grassland (BoFG), BoFG, which is the same level administrative institution as the Ministry of Agriculture and Rural Affairs and responsible for forestry and grassland management, enacted a special rule concerning GM trees, i.e., the Administrative Regulation on Management of Examining and Approving Methods for Genetic Engineering Activities of Forests (ARMEA-GMF), to regulate GM forestry-related management and authorization. In essence, this regulation is almost identical to RMS-AGMO, with the exception of subtle differences. For example, ARMEA-GMF also regulates research, testing, production, management, import, and export relating to GM forest trees. Compared with the agricultural regulations, there are two subtle differences worth noting: first, ARMEA-GMF formulates relatively detailed substantive standards for authorization, and second, more detailed authorizing procedures (more information in section 6.2.2 and 6.3.2).

Unlike agricultural GMOs, which are to be classified into four safety levels, according to the possible dangers caused to humans, animals, plants, microorganisms, and the ecological environment, GM trees are just categorized into three safety levels: level I refers to no danger found, level II refers to a low degree of danger, and level III means highly dangerous (Art. 7). GM tree testing also includes restricted field testing, enlarged field testing, and productive-testing. The national forest authority is in charge of the supervision and management of trees, and the municipal forest authorities are responsible for relevant management within their territories (Art. 5). The forestry authority shall formulate technical standards and technical specifications concerning safety assessment (Art. 6). Besides, a scientific institute, i.e., the Safety Committee for GM forest trees, is set up by BoFG. This authority is responsible for GM forest safety evaluation and supervision (Art. 5).

6.2 The Function of Administrative Risk Decisions on GMOs in the Form of an Authorization

It is a common practice that the legislature determines the form of the administrative act under what condition to intervene in dangerous situations through legislation, for which the executive has very little room for discretion. Generally, certain acts are potentially 
dangerous, but these potentially dangerous acts may be beneficial to society or individuals to some extent. Specifically, like coinage, those acts have two sides: on the one hand, they are potentially dangerous and, if unrestricted and allowed to be exercised at will by all members of society, may cause damage to persons and property of society or individuals and therefore are subjected to such restrictions and prohibitions as may be necessary for the protection of the public interest and of social order; on the other hand, such restrictions or prohibitions may cause missing business and development chances. Therefore, if they are identified as presenting a "basic risk" and "basic danger," legal restrictions and prohibitions on them are set up. However, such prohibitions can and should be removed under certain conditions in the form of an administrative authorization. The authorization reservation is mainly designed to control the occurrence of "basic dangers" and "basic risk" from a source. The assumption of such a "basic risk" or "basic danger" is generally within the legislature's prerogative of assessment. ${ }^{7}$

GMO-related activities, in particular the general release and marketing, are generally recognized as presenting basic risks. They are a kind of activity that has both potentials to cause harm in general and great benefit, which thus can only be carried out under particular conditions to prevent possible damages as far as possible, e.g., after a case-by-case risk assessment and adoption of appropriate safety measures. GMO risk is also highly uncertain, except for (especially due to the possibility that GMO damage might involve a wide range with its wide application. Therefore, the ex-ante precautionary control approach in the process of an administrative authorization is conducive to avoiding irreversible damage with relatively small management costs. Moreover, precaution is more appropriate than the prevention approach in the event of concrete danger or ex-post relief after the harm has been realized. Besides, since the protected legal interests affected by GMOs are anchored in constitutional law and carry great weight, ${ }^{8}$ the legislature is in principle empowered to set up permission requirements for GMOs without explicit scientific-empirical proof of the real risk potential of GMOs. ${ }^{9}$

\footnotetext{
${ }^{7}$ Federal Constitutional Court, BVerfGE 128, 1 No142

${ }^{8}$ Administrative Court of Appeal Kassel, Decision of 06.11.1989 - 8 TH 685 89, NJW 1990, 336 = NVwZ 1990, 336

${ }^{9}$ Federal Constitutional Court, BVerfGE 128, 1 No 142
} 
Accordingly, many of the activities concerning GMOs are subject to an authorization reservation. ${ }^{10}$ In other words, the authorization is a proactive measure widely applied worldwide to regulate GMO risks and is also a typical type of ex-ante administrative risk decision that the legislature empowers administrative authorities to make. Whether in Germany under the regulatory framework of the European Union or China, the authorization system is the core measure to control GMO risk. Although the requirements of authorization are the same, the scope of coverage, conditions, and procedures for authorizations are not identical. This section will describe the various categories of GMOrelated authorizations, their scope of coverage, and material conditions to grant permission. The following table states the typical categories of GMO-related authorizations in Germany/EU.

\footnotetext{
${ }^{10}$ Administrative Court of Appeal Kassel, Decision of 6. 11. 1989, NJW 1990, 336 = NVwZ 1990, 276. On release and placing on the market see also SRU, Umweltgutachten 1998, BT-Drs. 13/10195, para. 745 et seq.
} 
List of Typical Authorization concerning GMOs in Germany/the EU

\begin{tabular}{|c|c|c|}
\hline $\begin{array}{l}\text { Purpose of } \\
\text { Authorization }\end{array}$ & Coverage & Regulation \\
\hline \multirow[t]{2}{*}{$\begin{array}{l}\text { Activity of Contained } \\
\text { Use }\end{array}$} & GMMs & $\begin{array}{l}\text { Directive } 2009 / 41 \text { and } \\
\text { Gentechnikgesetz }\end{array}$ \\
\hline & GMOs and GMMs & Gentechnikgesetz \\
\hline Activity of Release & $\begin{array}{l}\text { GMOs (and combination of GMOs) } \\
\text { Excluding: } \\
\text { Exemption of organisms processed by techniques provided in Annex I B; } \\
\text { GMOs for marketing; } \\
\text { Medicinal substances and compounds for human use consisting of, or containing, a GMOs or } \\
\text { combination of GMOs; } \\
\text { GMOs for food and feed use. }\end{array}$ & $\begin{array}{l}\text { Directive 2001/18 and } \\
\text { Gentechnikgesetz }\end{array}$ \\
\hline Activity of Marketing & $\begin{array}{l}\text { Products containing or consisting of GMOs } \\
\text { Products obtained or produced from released GMOs without marketing authorization } \\
\text { Excluding: }\end{array}$ & $\begin{array}{l}\text { Directive 2001/18 and } \\
\text { GenTG }\end{array}$ \\
\hline
\end{tabular}




\begin{tabular}{|c|c|c|}
\hline & $\begin{array}{l}\text { Exemption of organisms processed by techniques provided in Annex I B; } \\
\text { GMOs as or in products concerning medicinal products for human and veterinary use; } \\
\text { Other GMOs subject to other provisions stricter or at least equivalent to Directive 2001/18; } \\
\text { GMOs for food and feed use. }\end{array}$ & \\
\hline $\begin{array}{l}\text { Activity of marketing of } \\
\text { GMOs for food and feed } \\
\text { use }\end{array}$ & $\begin{array}{l}\text { GMOs for food or feed use }{ }^{1} \\
\text { Food or feed containing or consisting of GMOs, } \\
\text { Food or feed produced from GMOs, } \\
\text { Food containing ingredients produced from GMOs } \\
\text { Excluding: } \\
\text { Food or feed produced with GMOs; } \\
\text { GMOs as Food additives }{ }^{2} \text {; } \\
\text { GMOs as Food flavorings }{ }^{3} \text {. }\end{array}$ & Regulation $1829 / 2003$ \\
\hline \multirow[t]{3}{*}{ Other activities } & GMOs as or in medicinal products for human and veterinary use & Regulation $1234 / 2008$ \\
\hline & Food additives containing, consisting of, or produced from GMOs & Directive 89/107 \\
\hline & Food flavorings containing, consisting of, or produced from GMOs & Directive $88 / 388$ \\
\hline
\end{tabular}

${ }^{1}$ As for GMOs as seeds, there are no special provisions on authorization requirements and procedures in Regulation 1829/2003 and Directive 2001/18, that is, it subjects to general GMOs, GM food or feed.

2 Authorized by Directive 89/107, but it shall be in compliance with the safety assessment provided in Regulation $1829 / 2003$.

${ }^{3}$ Authorized by Directive 88/388, but it shall be in compliance with the safety assessment provided in Regulation $1829 / 2003$. 


\subsubsection{Germany/the EU}

In Germany, under the EU framework, activities relating to green GMOs are divided into two groups. Accordingly, corresponding categories of administrative authorization are assigned to these activities. The first group of administrative decision-making in the form of an authorization regulates activities relating to GMOs for general use and is specified in GenTG in conjunction with Directive 2001/18/EC and Directive 2009/41/EC. This group comprises three categories of authorization: the authorization for release, for marketing, and for contained use. The second group comprises GMOs for food and feed use and is further divided into two categories of authorization, namely, for food use and for feed use. They are primarily regulated by Regulation (EC) No 1829/2003.

Whether an organism falls under the GMO authorization requirement is determined by the technology by which it is altered. According to Art. 3(3) and (3a) of GenTG, which correspond to Art. 2(2) of Directive 2001/18/EC, the GMO is defined as "an organism, with the exception of human beings, in which the genetic material has been altered in a way that does not occur naturally by mating and/or natural recombination," and is subject to the binding of this Directive and GenTG. In contrast, organisms processed by the techniques provided in Article 3(3a) of GenTG, i.e., in Annex I B of Directive 2001/18/EC, are not considered as GMOs; thus, their releasing or marketing activities do not fall under the requirement of GMO related authorizations. In addition, "naked” DNA, r-plasmids, and cell nuclei are not subject to the definition of both microorganism and organism. ${ }^{1}$ Therefore, for example, medicinal products merely derived by recombinant DNA techniques need only to undergo the normal pharmaceutical authorization procedure under Regulation 726/2004, other than GMO-related law. ${ }^{2}$

Overall, major operational processes of decision-making on GMOs for general use are in the hands of the member states, while GMOs for food and feed use, in contrast, are mainly

\footnotetext{
1 Rehbinder, et al., Pharming, 2008, p. 216.

2 Rehbinder, et al., Pharming, 2008, p. 217.
} 
processed at the EU level. Besides, the regulatory scope of each authorization, i.e., what kind of activities related to GMOs require authorization and can be conducted only after permitted by the competent administrative authority, are mutually disjoint. Each authorization may be limited to specific uses or activities involving GMOs (Art. 14 of GenTG). Since contained use activities (GMO works) generate less public controversy and are independent of other types of authorization, this paper does not discuss this category but focuses on the general release and marketing authorization.

\subsubsection{Decision-making on GMOs for General Use}

\subsection{Release of GMOs}

According to Art. 2 and Art. 14 of GenTG, in conjunction with Art. 5 and Art. 6 of Directive 2001/18/EC, the authorization for the release of GMOs (in EU law called "consent") regulates deliberate releases of GMOs. The authorization of release legitimates the activity of introducing the GMO or a combination of GMOs into the environment without specific containment measures. ${ }^{3}$ Unintentional escape, such as by accident, does not fall under the regulatory domain of release authorization. This kind of authorization excludes (1) releasing activities using GMOs on humans ${ }^{4}$, i.e., medicinal substances and compounds for human use, (2) marketing GMOs 5 , (3) marketing GMOs for food and feed use, and (4) releasing GMOs regulated by other stricter provisions than, or at least equivalent to, Directive 2001/18 (Art. 5(1) of Directive 2001/18/EC).

Regarding the principles and standards guiding decision-making, Directive 2001/18/EC explicitly refers to an overarching principle, i.e., the precautionary principle, in the goals provision of Art. 1 and fundamental obligation provided in Art. $4 .{ }^{6}$ Indeed, the precautionary principle is rather an abstract standard, and whether, and to what extent, it

\footnotetext{
${ }^{3}$ Directive 2001/18/EC Art. 2(3).

${ }^{4}$ They are mainly regulated by the Regulation $1234 / 2008$.

${ }^{5}$ Marketing of GMOs requires an application for marketing authorization.

${ }^{6}$ Rehbinder, et al., Pharming, 2008, p. 222.
} 
guides GMO decisions need to be explored; however, it is beneficial to create a higher degree of flexibility and capability to adjust to novel risk configurations and achieve regulatory innovations at the member states level. ${ }^{7}$ In addition, Art. 4 of Directive 2001/18/EC establishes a requirement that all appropriate measures are taken to avoid (direct or indirect) adverse effects on human health and the environment which might arise...". In contrast, in Germany Art. 16(1) of the GenTG further stipulates that an authorization for the release shall be granted to the applicant, on condition that (1) unacceptable harmful (adverse) effects on the interests protected by the Act are not to be expected, (2) all necessary safety measures are taken in line with the state of the art of science and technology, as well as (3) the applicant and the relevant responsible persons are reliable and the officer for biosafety (Beauftragter für die Biologische Sicherheit) is competent for the designed task (Art. 16(1) no 1 in conjunction with Art. 11 (1)). In particular, according to Art. 16 (1) of GenTG, the authority must examine whether, in the light of the state of scientific knowledge, unacceptable effects on human life and health and the environment are to be expected in relation to the purpose of the release, and whether and which kind of necessary safety measures have been taken. Thus, the state of science and technology is a decisive standard for making the decision.

Relying on the concrete material standard in Art. 16(1) in conjunction with the enumeration of the protected interest in Art. 1(1) of GenTG, the prevailing opinion concludes that the precautionary principle is inherent in the GenTG and constitutes the central guiding principle for decision-making. ${ }^{8}$ As mentioned in Section 5.2.1.2, (risk) precaution means that, if judging from the current state of knowledge, there are grounds for concern that legal interests may be threatened, appropriate ex-ante precautionary measures are to be taken to prevent or limit the materialization of such risk with low probability or the uncertain risk. When applying the precautionary principle in relation to specific decision-making premises, the two constituent connotations of the precautionary

\footnotetext{
${ }^{7}$ Rehbinder, et al., Pharming, 2008, p. 226.

${ }^{8}$ Pottschmidt, Gentechnikrecht, in: Rehbinder \& Schink (eds.), Grundzüge des Umweltrechts (5th edition), 2018, p. 1166; Wahl \& Appel, Prävention und Vorsorge: Von der Staatsaufgabe zur rechtlichen Ausgestaltung, in: Wahl \& Appel (eds.), Prävention und Vorsorge, 1995, p. 104 et seq.
} 
principle make their application rather complex and uncertain. These are the likelihood of effect and adversity of effect.

As for the standard identifying the "likelihood of effect", it is far from clear. Generally, provided that possible adverse effects, according to the present state of scientific knowledge, can neither be positively determined nor ruled out, but there is reason to believe that they may occur, they have to be excluded (Art. 16(1) of GenTG) ${ }^{9}$ The German administrative courts take "justified grounds for concern" as the threshold of finding "adverse effects" 10 . The EU Courts have taken the view that the finding of adverse effects has to be justified by some scientific foundation, i.e, scientifically plausible grounds for concern, which does not necessarily require being supported by empirical findings; ${ }^{11}$ however, with respect to mere hypothetical risk, precautionary measures are not permitted. This limitation is based on an assumption that post-authorization monitoring provides an additional safety guaranty, thus not all potential risks need to be ruled out. Moreover, according to Rehbinder, some "prudential" elements have already to be applied in the scientific risk estimation process to adapt to scientific uncertainty. ${ }^{12}$ For instance, even though transferring the data or rules obtained from one kind of particular plant to another plant is in principle feasible, one must estimate the non-occurrence of adverse effects with caution, for example, by applying safety factors for such transfers.

As regards the adversity of GMOs, they encompass both direct and indirect effects, immediate and delayed effects, environmental and other effects. ${ }^{13}$ Nevertheless, the examination of the application is limited to risks for humans and the environment. Generally, the notion of environment comprises all media and elements that constitute the

\footnotetext{
${ }^{9}$ Rehbinder, et al., Pharming, 2008, p. 229.

${ }^{10}$ Rehbinder, et al., Pharming, 2008, p. 229; for further information, see: Administrative Court Gießen, Neue Zeitschrift für Verwaltungsrecht - Rechtsprechungs-Report 1993,534,537/38; Administrative Court Berlin, Neue Zeitschrift für Verwaltungsrecht - Rechtsprechungs-Report 1994,150,152; Zeitschrift für Umweltrecht 1996, 146,147.

${ }^{11}$ Rehbinder, et al., Pharming, 2008, p. 229. for further information, see: European Court, 2002 ECR II-3305 Nos. 143-146,152 - Pfizer Animal Health; 2002 ECR II-4945 Nos. 181 et seq. - Artegodan; case T-229/04, 2007 ECR II-2441 No. 161 - Sweden/Commission.

12 Rehbinder, et al., Pharming, 2008, p. 229.

${ }^{13}$ Rehbinder, et al., Pharming, 2008, p. 230-231.
} 
environment as well as their interrelationship. Other interests, such as socio-economic impacts (especially "co-existence"), are only mentioned in the goals provision of Art. 1 no 2 of the GenTG and in the context of requirements for the cultivation and processing as well as liability (Art. 16a, 16b, and 36a). Besides, an adverse effect is a qualified effect and more than a simple alteration of the environment. ${ }^{14}$ This means that a simple alteration of the environment is not regarded as an (unacceptable) adverse effect. In practice, the criteria for identifying and evaluating adverse effects to the protected interest are rather uncertain. In Germany, two standards, i.e., naturalness (equivalence to nature) and selective advantage, are recognized for assessing the adversity of an effect. Equivalence to nature, referring to the situation that the same kind of effect can occur naturally or by conventional breeding, is not treated as an adverse effect or at least is considered as an acceptable effect. The same is true for the lack of new selective advantage. This is because a new selective advantage may possess strong propagation potential and higher vitality, which is likely to affect the ecological balance and, therefore, has to be evaluated; otherwise, it will not. However, according to Rehbinder, it is still questionable whether the two criteria mentioned above can adequately and appropriately serve the function of assessing risk (adverse effect), given the limited human understanding of the systemic, spatial, and temporal interrelationships to nature and the dynamic and complex nature of ecosystems. ${ }^{15}$ Moreover, there is another flaw in the criteria of naturalness and selective advantage, which are confined to the environmental effect, and do not necessarily take the protection of human and animal health into consideration. For example, some eco-toxic effects of GM plants are independent of whether they are directly associated with the modified gene sequence or caused indirectly by a change in the metabolism of the plant. But different kinds and extents of exposure may cause different adverse effects. The selective advantage cannot adequately assess those adverse effects; conversely, significance (threshold concentrations) and exposure are more effective. ${ }^{16}$ For another instance, the standard of naturalness and selective advantage does not either cover those possible adverse effects of resistance to

\footnotetext{
${ }^{14}$ Rehbinder, et al., Pharming, 2008, p. 232.

${ }^{15}$ Rehbinder, et al., Pharming, 2008, p. 232.

${ }^{16}$ Rehbinder, et al., Pharming, 2008, p. 232.
} 
pharmaceuticals from the involuntary intake of such substances in GM food or feed. The causation of resistance to treatment with antibiotics through gene transfer should be identified as an adverse effect. Therefore, the consideration of other factors, such as natural variation of affected ecosystems and their development trends, as well as impacts on affected species, becomes a complementary choice. ${ }^{17}$ In addition, due to uncertainty and complexity of risk, the "case by case" risk assessment is applied in the process of authorization.

Under German law, the principle of cost-(risk-) / benefit-analysis, is applied to release and marketing decisions. This is suggested by the expression of "unacceptable harmful (adverse) effects" in Art.16(1) no 3 of GenTG ${ }^{18}$. However, EU law (Art. 4 of Directive 2001/18) does not explicitly provide for a risk (cost)/benefit analysis. Literally, it gives the impression that German Art. 16(1) GenTG is inconsistent with EU Art. 4 Directive 2001/18. However, the principle of cost-(risk-)/the benefit-analysis could be inherent in the principle of proportionality, which is generally to be respected in applying the precautionary principle (Art. 5(4) EU Treaty) and therefore also applicable in the context of GMO regulation. ${ }^{19}$ Therefore, arguably German and EU law is consistent in the application of this principle. It must be noted that the above substantive requirements for granting an authorization are rather abstract; thus, the stringency of legal control by means of administrative decisions largely depends on the procedural requirements.

\footnotetext{
${ }^{17}$ Rehbinder, et al., Pharming, 2008, p. 230; for further information see: Sachverständigenrat für Umweltfragen 1998, Nos. 813 et seq.

${ }^{18}$ GenTG Art. 16 Authorization for release and placing on the market

(1) Approval for a release shall be granted if.

1 the requirements according to $\S 11$ para. 1 no. 1 and 2 are met,

2. it is ensured that all safety precautions required by the state of the art in science and technology are taken, 3. according to the state of scientific knowledge in relation to the purpose of the release, unacceptable harmful effects on the legal interests specified in $\S 1$ No. 1 are not to be expected.

${ }^{19}$ Pottschmidt, Gentechnikrecht, in: Rehbinder \& Schink (eds.), Grundzüge des Umweltrechts (5th edition), 2018, p. 1166; Winter, Naturschutz bei der Freisetzungsgenehmigung für gentechnisch verändertes Saatgut, ZUR 2006, p. 457.
} 


\subsection{Marketing of GMOs}

The making of GMOs available to third parties, other than for the contained use and deliberate release of the GMOs, has to be justified by a marketing authorization (called "consent"). ${ }^{20}$ In contrast to the authorization of GMO releases, it is irrelevant whether the GMO products were created deliberately or accidentally for obtaining the marketing authorization. ${ }^{21}$ Regarding the regulatory scope of marketing authorization, it covers activities whereby anyone places on the market products that (1) contain or consist of GMOs, and (2) contain or consist of GMOs not having a marketing authorization for that purpose, and (3) are produced from released GMOs not having a marketing authorization (Art. 13 of Directive 2001/18/EC and Art. 14(1) no 2-4 of GenTG). In the cases of (1) marketing activities using GMOs on humans ${ }^{22}$, (2) marketing GMOs for food and feed use, and (3) other marketing of GMOs subject to provisions on risk assessment, risk management, labelling, monitoring, and information of the public that correspond to or are more stringent than Directive 2001/18 (Art. 12(1) of Directive 2001/18/EC and Art. 14 of GenTG), these activities are not deemed to fall under the authorization requirement for marketing under the GenTG.

Art. 16 (2) GenTG provides that "A marketing authorization shall be granted or renewed if, based on the state of the art of science and technology, no unacceptable harmful effects on the legitimate interests referred to in Art. 1(1) in relation to the marketing purpose are to be expected." From the perspective of the material standard, in light of current scientific knowledge, as long as unacceptable damage to human life and health and the environment is not to be expected, a marketing authorization will be granted to the applicant. At the fact-finding stage, the authorization is based on the state of art of science and technology. At the normative stage, the evaluation of the acceptability of risk needs to be made by the administration. The legislature did not expressly delegate a margin of appreciation (Beurteilungsspielraum) to the authority to decide whether the risk was "acceptable."

\footnotetext{
${ }^{20}$ Directive 2001/18/EC Art. 6(8) in conjunction with Art. 2(4)

${ }^{21}$ Kauch, Gentechnikrecht, 2009, p. 80.

${ }^{22}$ They are mainly regulated by the Regulation $1234 / 2008$.
} 
However, the prevailing opinion, including the administrative courts, recognizes that the GenTG implicitly confers a margin of appreciation on the competent authority. This is mainly based on the argument that the statutory provision of organized scientific input into the process by involving the ZKBS in risk assessment reflects an assignment of responsibility for making risk decisions to the executive. ${ }^{23}$ It must be noted that the recognition of a margin of appreciation is not inconsistent with EU law (see 6.2.1.2)

\subsubsection{Decision-making on GMOs for Food and Feed Use}

GMOs and related products for food and feed use, based on their intended purpose, are subject to the requirement of a special authorization according to Regulation (EC) No 1829/2003. The authorization covers GMOs for food and feeds use, respectively. The regulation is uniformly applied within the EU for ensuring the free movement of safe and wholesome food and feed, a high level of protection of humans and animals, the environment, and related consumer interests. ${ }^{24}$

Specifically, in accordance with Art. 3(1) and Art. 15, four types of GMO food and three types of GMO feed fall under the respective authorization reservations: (1) GMOs for food/feed use, (2) food/feed containing or consisting of GMOs, (3) food/feed produced from GMOs, (4) food containing ingredients produced from GMOs. The coverage of the authorization for food and feed is almost the same, except that the authorization for food additionally includes "(4) food containing ingredients produced from GMOs". GMOs for food or feed use refer to the GMOs as raw material or for direct consumption (Art. 2(8) of Regulation 1830/2003). Food or feed containing GMOs means that the product contains the GMOs as one of the ingredients. Food or feed consisting of GMOs means GMOs just make up the products without any other ingredients. Food produced from or containing

\footnotetext{
${ }^{23}$ Federal Administrative Court, NVwZ 1999, 1323. 1324-25; Administrative Court of Appeal Berlin, NVwZ 995, 1023. 1024; Pottschmidt, Gentechnikrecht, in: Rehbinder \& Schink (eds.), Grundzüge des Umweltrechts (5th edition), 2018, p. 1202.

${ }^{24}$ Regulation (EC) No 1829/2003 preamble 1-4.
} 
ingredients produced from GMOs usually refers to the case that the product is derived, in whole or in part, from the respective GMOs, so that either the physical or chemical nature of the product has been changed (Art. 2(10) of Regulation 1830/2003). Even though the regulation has laid down food- and feed authorization provisions separately, the rules are by and large the same. If a product could be both used for food and feed, the applicant shall apply for both authorizations and meet all relevant requirements. In case that any one of the four types of GMO food has been authorized, the authorization works for all other three types of GMOs (Art. 4(4)). The same is true for GMO feed. However, according to the preambles (13), (15), and (16), when (1) food or feed is produced with GMOs²5, (2) GMOs are used as food additives ${ }^{26}$, (3) or used as food flavorings ${ }^{27}$, they do not fall under the scope of authorization of Regulation (EC) No 1829/2003.

The material requirements for the authorization take into account the interest in free movement of safe and wholesome food and feed, social and economic interests, a high level of protection of human life, health, and animal health. Art. 4 lays down the concrete material requirements. The food or feed (1) may not have adverse effects on human health, animal health, or the environment, (2) not mislead the consumer as well as (3) not differ from the food which it is intended to replace to such an extent that its regular consumption would be nutritionally disadvantageous for the consumer, a marketing authorization shall be granted. Compared with Directive 2001/18/EC, Regulation (EC) No 1829/2003 does not explicitly refer to the precautionary principle. Instead, it mentions the "evaluation of potential risk," such as in preamble 30. Socio-economic or other legitimate factors relevant to the matter under consideration may be relevant (preamble $1,32 \& 43) .{ }^{28}$ When exercising

\footnotetext{
${ }^{25}$ Food or feed produced with GMOs refers to a product derived from a genetically modified source material but which is not present in the food or in the feed. For instance, a bread produced with GM yeast is a kind of food produced with GMOs but does not consist of any GMOs or its ingredient. Food produced from GMOs refers to an ingredient of food is produced from GMOs and includes GMO ingredients, such as potato cakes made from GM potato.

${ }^{26}$ Their authorization is regulated by Council Directive 70/524/EEC of 23 November 1970 concerning additives in feeding stuffs.

${ }^{27}$ Its authorization is regulated by Council Directive 88/388/EEC of 22 June 1988 on the approximation of the laws of the Member States relating to flavourings for use in foodstuffs and to source materials for their production.

28 "The international trade commitments of the European [Union] and of the requirements of the Cartagena Protocol on Biosafety to the Convention on Biological Diversity as regards importer obligations and notification"
} 
the power to authorize the GMO, the authority is required to prevent specific potential risks to public health, safety, and the environment giving the protection of those interests preference over economic interests. ${ }^{29}$ The uncertainty of risk and limitations of science are recognized in Preamble 32. Therefore, the material requirements can be interpreted to the extent that the Regulation recognizes the precautionary principle. Moreover, it can be concluded that, due to a lack of scientific knowledge, risk decision-making needs to be extensively supplemented by normative evaluation in order to reconcile conflicting interests.

It is well established that, in response to the cognitive problems and science-dependence of risk assessment and risk decision-making, the competent EU authorities are granted a broad margin of appreciation (contrary to the German understanding, often denoted as "discretion") to evaluate the risk and determine the level of risk deemed unacceptable for society. In a recent GM food/feed case, the EU Court of Justice and the General Court confirmed that the Commission enjoys a wide measure of discretion ${ }^{30}$, where it is called upon to make complex assessments. ${ }^{31}$ In accordance with the caselaw, the responsibility to "determine the critical probability threshold for adverse effects on human health and for the seriousness of those possible effects which is no longer acceptable for society" is subject to the political choice of the EU authority. ${ }^{32}$ This means that the Commission enjoys

\footnotetext{
is mentioned in Recital 43, which may be taken into account by the Commission. However, some scholars have criticized that although there are formal considerations beyond safety, other relevant factors are never seriously considered. Kritikos, Traditional Risk Analysis and Releases of GMOs into the European Union: Space for Non Scientific Factors?, European Law Review Vol. (2009), p. 405.

${ }^{29}$ General Court, TestBioTech eV and Others v European Commission, Case T-177/13, ECLI:EU: T:2016:736 Paragraph 108; Dow AgroSciences and Others v Commission, Case T-475/07, EU:T: 2011:445, paragraph 144.

${ }^{30}$ General Court, TestBioTech eV and Others v European Commission, Case T-177/13, ECLI:EU: T:2016:736 Paragraph 77; Court of Justice, Case C-82/17 P, ECLI:EU:C:2019:719, Paragraphs 38; Paskalev, Losing the Battle, but Winning the War? Standing to Challenge GMO Authorisations and other Acts Concerning the Environment, European Journal of Risk Regulation Vol. 8 (2017), p. 583.

${ }^{31}$ Ahead of the TestBioTech case , the relevant rulings on pharmaceuticals and hazardous substances had already recognized that the relevant authorities enjoy a wide margin of discretion when making a risk decision, such as Court of Justice, Upjohn, Case C-120/97, EU:C: 1999:14, paragraph 34; General Court, Pfizer Animal Health SA v Council, Case T-13/99, ECLI:EU:T:2002:209, paragraph 166; see generally Hofmann, Rowe \& Türk, Administrative Law and Policy in the European Union, 2011, p. 494 et seq.

See: https://oxford.universitypressscholarship.com/view/10.1093/acprof:oso/9780199286485.001.0001/acprof9780199286485

${ }^{32}$ General Court, TestBioTech eV and Others v European Commission Case T-177/13, ECLI:EU: T:2016:736, Paragraph 105; Dow AgroSciences and Others v Commission, T-475/07, EU: T: 2011:445, paragraph 148.
} 
discretion (in the German terminology: a margin of appreciation) to determine the level of risk deemed acceptable for society. Besides, when authorizing GM food/feed, even though it has to "take account of EFSA's opinion, any relevant provisions of EU law and other legitimate factors relevant to the matter under consideration", the Commission has discretion and is not obliged to comply with EFSA's opinion in substantive terms..$^{33}$ Indeed, when determining the acceptability of risk, the EU institutions are bound by the precautionary principle and other obligations, such as arising under the first subparagraph of Article 168(1) TFEU, to ensure a high level of human health protection. ${ }^{34}$ According to the case law, the Commission's discretion for evaluating the GM food/feed risk and determining its acceptability level is subject to judicial review ${ }^{35}$, which, yet, is limited to verify whether the decision in question "is not vitiated by a manifest error or a misuse of powers and that the competent authority did not clearly exceed the bounds of its discretion". ${ }^{36}$ Besides, it is entirely discretionary for the authority to adopt which kind of final measure to take following a judicial review. ${ }^{37}$

\footnotetext{
${ }^{33}$ General Court, TestBioTech eV and Others v European Commission, Case T-177/13, ECLI:EU: T:2016:736 Paragraph 103; Dow AgroSciences and Others v Commission, T-475/07, EU:T: 2011:445, paragraph 87; Questions and Answers on EU's policies on GMOs

See: http://europa.eu/rapid/press-release MEMO-15-4778 en.htm

${ }^{34}$ General Court, TestBioTech eV and Others v European Commission, Case T-177/13, ECLI:EU: T:2016:736, Paragraph 106 \& 108.

${ }^{35}$ Since GM food/feed law, i.e., Regulation (EC) No 1829/2003, aims to “...contribute[s] significantly to the health and well-being of citizens, and to their social and economic interests" and ensure a "high level of protection of human life and health, animal health and welfare, environment and consumer interests in relation to genetically modified food and feed", it falls within the legal definition of environmental law in Art. 2(1)(f) of Regulation (EC) No 1367/2006 (Application of the Rules of the AarhusConvention on Access to Information, Public Participation in Decision-making and Accss to Justice in Environmental Matters to Community institutions and bodies), as amended by Regulation (EU) No 2021/1767. In that case, according to Art. 10(1) and Art. 12 of Regulation (EC) No 1367/2006, regarding each GM food/ feed authorization, certain nongovernmental organisations are entitled to make a request for internal review on them and file a lawsuit when the Commission fails to act as legally required. The judicial review is limited to identify whether the exercise of the Commission's discretion for evaluating GM food/feed is illegal for "lack of powers, infringement of essential procedural requirements, infringement of the treaties or of any legal rule relating to their application, or misuse of powers". See: General Court, TestBioTech eV and Others v European Commission, Case T-177/13, ECLI:EU: T:2016:736 Paragraphs 56, 59; Court of Justice, Case C-82/17 P, ECLI:EU:C:2019:719, Paragraph 38. ${ }^{36}$ General Court, TestBioTech eV and Others v European Commission Case T-177/13, ECLI:EU: T:2016:736 Paragraphs 77; Court of Justice, TestBioTech e.V. and Others v. European Commission, Case C-82/17 P, ECLI:EU:C:2019:719, Paragraphs. 38; Upjohn Ltd v The Licensing Authority and Others, Case C-120/97, EU:C:1999:14, paragraph 34.

${ }^{37}$ General Court, TestBioTech eV and Others v European Commission, Case T-177/13, ECLI:EU: T:2016:736, Paragraph 55.
} 


\subsubsection{China}

To strengthen the safety management of green GMOs, safeguard human health and the safety of animals, plants, and microorganisms, protect the ecological environment, and promote green GMO technology research, Chinese legislatures have formulated a series of categories of administrative authorization for GMO related activities. Environmental interests, human health, and freedom of research are all protected; however, the exact value priority is not stated. The objects of authorization can be divided into two groups: authorization for agricultural GMOs, which are mainly regulated by RMS-AGMO, and authorization for GM forestry trees, specified in the ARMEA-GMF. Each group contains the same nine categories of authorizations: Research, restricted field-testing, enlarged fieldtesting (also named environmental release), productive testing, biosafety certification, producing, processing, marketing, and importing. Although RMS-AGMO and ARMEAGMF regulate agricultural GMOs and GM forestry trees, respectively, their authorizing categories, standards, and procedures are almost identical. If not otherwise specified, the subsequent description of authorization of GMOs in China applies to agricultural GMOs and GM forestry tree species as well.

Classifying according to the contents of authorizations, there are nine categories of authorizations that can also be grouped into two kinds: for activities concerning GMOs (with eight categories of authorization) and for confirming GMO safety (with one category of authorization). Authorization for confirming the safety of GMOs contains only Biosafety Certification. To put it succinctly, the biosafety certification is designed to confirm that a GMO is generally safe, and other authorizations are used to regulate the activities related to GMOs. By contrast, the other eight categories of authorization are designed for the activities concerning GMOs. 


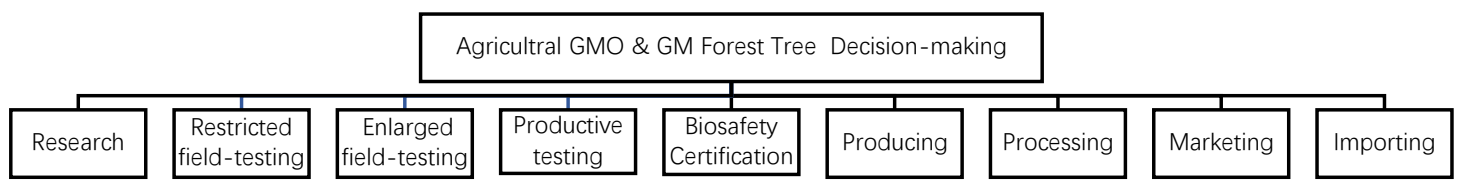

Even though each authorization corresponds to a different range of activities or objects, they are not completely independent of each other. Almost all authorizations are centered on the Biosafety Certification, one of the preconditions for applying for authorization of production, marketing, and import of the concerned GMOs. In other words, the Biosafety Certification is one of the necessary premises for granting subsequent authorizations for production, operation, marketing, and import of the relevant GMOs. However, the Biosafety Certification can only be applied for after the relevant operator has carried out the experimental research, restricted field-testing, and enlarged field-testing, all subject to specific authorization requirements. The operator can only apply for the authorization in the order of experimental research, testing (restricted field-testing, enlarged field-testing, productive testing), and biosafety certification. In contrast, subsequent authorizations, i.e., for production, operation, marketing, and import, are independent.

To be more specific, the authorization for research covers experimental research activities and research, by the way, genetic manipulation conducted in a laboratory control system ${ }^{38}$ (Art. 44(9) of ARMSA-AGMO). The research authorization is required for agricultural GMOs with safety levels III and IV or GM forest tree species with safety level III (Art. 12 of RMS-AGMO; Art. 9 of ARMEA-GMF). In contrast, whoever is engaged in research on agricultural GMOs or GM forest tree species with safety levels I and II can start the operation straight away. After performing the research, the relative actor must apply for permission for the next stage of restricted field-testing. Restricted field-testing is a smallscale test conducted within a control system or under controlled conditions (Art. 44(10) of ARMSA-AGMO). Authorization for research and restricted field-testing, in essence, is not

\footnotetext{
38 According to Art. 44(13) of ARMSA-AGMO, a control system is a closed or semi-closed operating system established by physical, chemical, and biological control.
} 
a strict authorization but merely an obligation for the applicant to notify and register with the competent administrative authority to keep them informed, which is designed for the subsequent administrative supervision on the relevant activities. After that, enlarged fieldtesting and productive testing fall under the strict reservations of an authorization. The authorization for enlarged field-testing covers medium-scale tests conducted under natural conditions with appropriate safety measures (Art. 44(11) of ARMSA-AGMO). Authorizations for productive testing are designed for larger-scale testing prior to production and use (Art. 44(12) of ARMSA-AGMO).

Unfortunately, China's legislation does not provide any substantive decision-making criteria but just indicates that "only if the testing passes the safety assessment conducted by the Biosafety Committee on agricultural GMOs, ... the authorization shall be granted" (Art. 15 of RMS-AGMO in conjunction with Art. 22 of ARMSA-AGMO). Coincidentally, the same expression is also stipulated for issuing a biosafety certification (Art. 15 of RMSAGMO in conjunction with Art. 24 of ARMSA-AGMO). "Passes the safety evaluation" is a somewhat puzzling expression, which cannot be interpreted as "confirming the safety of the related activity," nor can it be read as "the activity is acceptable." Other than that, there is no further criterion prescribed. Theoretically, risk identification is a scientific issue, and the determination of acceptability of risk is a question of interest evaluation by the administration. In fact, from the material rule of Art. 15 of RMS-AGMO, it can be concluded that a professional "risk assessment" is the only visible basis for risk decisionmaking. In other words, risk identification at the factual level is mixed with the interest evaluation at the normative level, or rather, the value evaluation is hidden behind the scientific assessment.

Upon completing the three phases of testing, the operator can apply for a biosafety certification for the relevant GMOs (Art. 16). Indeed, as long as the GMOs are intended for production, further processing, marketing, and importing, a biosafety certification must first be granted. Likewise, barely any substantive standard is being set down here, but procedural requirements are emphasized. For example, Art. 15 of RMS-AGMO, in 
conjunction with Art. 24 of ARMSA-AGMO, prescribes that the Ministry of Agriculture shall require the Biosafety Committee on Agricultural GMO upon receipt of the application to conduct a safety assessment and entrust a qualified technical testing organization to conduct an independent inspection. Only after the safety assessment on GMO has been passed, a biosafety certification is issued". Besides, no material principles are laid down to guide administrative decision-making in RMS-AGMO. However, as regards the decisionmaking standard relating to agricultural GMOs, ARMEA-GMF has added a material requirement in the process of issuing the biosafety certification for GM forest trees. Art. 14 prescribes: "After the safety assessment on GM forest has been passed, BoFG shall take technical, economic and social factors into consideration before issuing a biosafety certification." Despite the abstract wording, this provision suggests that the administration needs to weigh the various interests of society adequately.

In addition to acquiring a biosafety certificate, GMO researchers and developers have to complete some other procedures before the GMO species can be put into commercial use and be available on the market, i.e., in production, further processing, and marketing. Specifically, GMO production usually refers to natural cultivation and breeding by deploying the GM seeds, breeding livestock and poultry, or aquatic fry and seeds. In other words, it is a process of the industrial manufacture of GM products that contain, are composed of, or are produced from GMOs and use the living GMOs as a raw material. Marketing refers to general selling. The authorizations for production and GMO marketing are not specific authorizations laid down in the GMO law. The operator can - and may have to - apply for other authorizations for production and marketing as provided for in relevant laws and administrative regulations, such as Seed Law.

RMS-AGMO has laid down some additional requirements for authorizations for production and marketing related to agricultural GMOs; mainly, the concerned GMOs must have been granted a biosafety certificate before the subsequent production and marketing can start. For example, Art. 19 of RMS-AGMO stipulates that, in addition to the conditions contained in the relevant laws and administrative regulations, an operator applying for an 
authorization for production of GMOs, which is GM plant seeds, breeding livestock and poultry, or aquatic seeds(or breeding), shall meet the following conditions: (1) Obtaining an agricultural GMO biosafety certification and passing the validation of variety ${ }^{39}$; (2) cultivating or breeding in designated areas only; (3) have appropriate safety management and preventive measures in place. With regard to the further processing of GMOs, the operator shall apply for the specific authorization of further processing of agricultural GMOs from a provincial agricultural authority, which is regulated by AREAP-AGMO. However, the biosafety certificate is also a precondition for authorizing further processing. In short, the major most stringent element of RMS-AGMO's control over GMOs is that a biosafety certificate is required.

In general, imported GMOs may be used for seven different purposes, the same as domestic ones, i.e., for research and testing (restricted, enlarged, productive), production, marketing, and further processing. According to RMS-AGMO, in conjunction with ARMSI-AGMO or ARMEA-GMF, they are all subject to the importing authorization requirement, for which MoA or BoFG are responsible. Admittedly, different requirements are assigned in accordance with the distinction between different categories of import authorizations in RMS-AGMO or ARMEA-GMF. In addition to the relevant import-related authorization requirements under the RMS-AGMO and ARMSI-AGMO, the ARMIQEE-GM Products also formulates special independent authorization requirements for GM products for importers, for which Customs is responsible. In other words, after having obtained the relevant authorization prescribed in RMS-AGMO, the operator must apply for an authorization under ARMIQEE-GM Products. Only with the approvals from both the MoA or BoFG and the Customs the relevant products can enter China and be used for the corresponding purposes. Decision-making in relation to importing GMOs is, as a matter of

\footnotetext{
${ }^{39}$ Validation of a variety is based on the results of regional tests of varieties or the performance of production trials, against the variety validation standards, to comprehensively evaluating the newly bred or newly introduced varieties' adaptation to the region, application value, social benefit and corresponding cultivation technology, so as to determine whether and where it is suitable for promotion. It includes three groups: variety of plant seed, variety of breeding livestock and poultry, and variety of aquatic seeds. For example, according to the Art. 15 of Seed Law of China: "Major crop varieties and major forest species shall pass national or provincial seed validation before promotion. The varieties applying for validation shall meet the requirements of specificity, consistency and stability."
} 
fact, not just one decision but a cluster of decision-making. Overall, China's regulations on imported GMOs are relatively strict. The applicable law also contains a rare requirement of a substantive nature. There is a requirement that "no danger to humans, animals, plants, microorganisms, and the ecological environment" may be caused if the imported GM products are used for further processing (Art. 32 of RMS-AGMO). However, how to interpret this standard is far from being clear and not discussed by Chinese scholars.

\subsection{Procedural Level of Administrative Decision-making on GMO Risks}

In combination with the general procedural theory of risk decision-making in Chapter 2, the following sections will examine in detail how this process of decision-making is implemented regarding GMO authorizations to control uncertain risk in Germany/the EU and China, respectively. The procedural elements of administrative risk decision-making, i.e., participants and procedure, will be analyzed. The following text is a hypothetical case study of an application submitted in Germany. In Germany/the EU, the procedure is highly complex. In the first place, this is due to the characteristics of the multi-level structure of the EU system of governance in which the European (central) interest must be balanced against the interests of the member states and a variety of actors from EU institutions and national governments and stakeholder groups from industry and civil society participation in the process. Secondly, the problem structure, that is, the characteristics of potential risks presented by GMOs, ranging from a high degree of uncertainty and even ignorance to deficiencies of acceptance, is reflected by the complexity of the procedure. In contrast to Germany/the EU, procedural provisions of China are much more straightforward.

\subsubsection{Germany/the EU}

\subsubsection{Participants in the Procedure}

According to the German/EU law listed in Section 6.1.1, six groups of actors are involved in GMO administrative risk decisions. They are respectively: the competent administrative 
authority, the cooperating decision-making administrative authorities a scientific institute, consulted institutes, the applicant, and the public. Each group plays a different role regarding different categories of GMO authorization.

\subsection{Competent Decision-making Authority}

The competent decision-making authority refers to the administrative organ that is responsible for, on the one hand, organizing the administrative authorization process or/and holds the core decision-making power over one or several GMO authorizations; on the other hand, it supervises the authorization activities, such as a higher supervisory authority. Since the EU rules on GMOs for regular use are laid down in the form of a "directive" that is addressed to the member states of the EU, it needs to be transposed into member states' law and implemented by the member states. The authorization for GMO releasing is mainly carried out by the member states. As regards marketing authorizations, there is a stronger supra-national element with partly shared competencies. When decisions are taken at the EU level, which is the case where objections have been raised to the proposed grant of an authorization, this is done in the comitology procedure. This means that normally the majority of competent decision-making authorities from the member states decide. In contrast, the GMOs rules for food and feed use in the EU are laid down in the form of a "regulation," and the EU institutions are in full charge of organizing the relevant authorization activities, even though decisions are also taken in the comitology procedure and therefore also involve the member state authorities.

\subsection{Release and Marketing of GMOs}

Before 2004, the Robert Koch-Institut $\left(\mathrm{RKI}^{40}\right)$ was in charge of authorizing release and marketing activities in Germany. Since April 2004, the authorizing power has been

\footnotetext{
40 The Robert Koch-Institut is the Public-Health-Institute for Deutschland. See:https://www.rki.de/DE/Home/homepage_node.html;jsessionid=8DC7D8046732D81F1146385E2F4DF34B. $2 \operatorname{cid} 363$
} 
conferred on the Federal Office of Consumer Protection and Food Safety (Bundesamt für Verbraucherschutz und Lebensmittelsicherheit, abbreviated as BVL) ${ }^{41}$. All activities related to GMO release and marketing are subject to the requirement of applying to the BVL before carrying out. Nowadays, BVL is the chief controller of GMO governance in Germany.

In short, in the process of authorizing the release and marketing of GMOs, the competent federal authority, i.e., the BVL, is mandated to receive the relevant application, organize the information exchange and publication, coordinate the authorities involved in the authorization procedure and the public, and finally decide on the GMO authorization (Art. 16, 16d, 18, 31 of GenTG). After the release or marketing, in order to keep up with technological development, anticipate risks as far as possible, and avoid unexpected damage, BVL is also responsible for monitoring and supervising the implementing status of released GMOs (Art. 16a, 25 of GenTG), gather information (Art. 29 of GenTG), and update his authorization decision when necessary (Art. 20, 26 of GenTG).

However, the European Commission and competent authorities of other concerned member states and the other Contracting States to the Agreement on the European Economic Area (hereafter as Contracting States) extensively participate in the marketing authorization process (see 6.3.1.2.2.3-5).

\subsection{Marketing of GMOs for Food and Feed Use}

The authorization of GMOs for food and feed use is mainly organized by the European Commission (Art. 7 of Regulation (EC) No 1829/2003). The Commission is assisted in the process of organizing the decision-making by the European Food Safety Authority (abbreviated as EFSA) as well as the competent national authorities concerned, such as BVL for Germany. The assistance by EFSA and BVL constitutes a procedural support for the European Commission, for example, in receiving applications and forwarding applications,

\footnotetext{
${ }^{41}$ Article $1 \S 21$ of the Law on the Restructuring of central institutions of public health (Gesetz über die Neuordnung zentraler Einrichtungen des Gesundheitswesens- GNG) of 24.06.1994 (Federal Gazette I 1994, p.1416).
} 
communicating information, and carrying out risk assessments. Although other institutes assist the European Commission, it is responsible for drafting a decision, essentially based on the professional opinion of the EFSA. Thereby, EFSA has a crucial role in the authorization process.

An important unit of EFSA is the Standing Committee on the Food Chain and Animal Health. One of its major roles lies in its decision-making competence in the comitology procedure provided for all major decisions on GM food and feed to be taken by the Commission (Art. 35 of Regulation 1829/2003). The Standing Committee on the Food Chain and Animal Health is made up of representatives from member states. It performs the function of coordinating its members' views and overseeing the European Commission's decision-making to ensure that the state of scientific knowledge is duly- taken into account and legitimate interests of the member states and stakeholders in the food chain are protected.

\subsection{Cooperating Decision-making Authorities}

To comprehensively obtain information, avoid neglecting particular interests in need of protection and reconcile conflicting interests in a rational way, risk decisions about GMOs are not made exclusively by one or two competent administrative bodies but often jointly by involving those authorities whose missions are affected by the project. ${ }^{42}$

As for the authorization of release and marketing of GMOs, the BVL has to make the decision in concert with the Federal Agency for Nature Conservation (Bundesamt für Naturschutz, abbreviated as BfN), the Robert Koch Institute, ${ }^{43}$ and the Federal Institute for Risk Assessment (Bundesinstitut für Risikobewertung, abbreviated as BfR) ${ }^{44}$ (Art. 10, 16 of

\footnotetext{
${ }^{42}$ The cooperative authority form does not exist regarding the marketing of GMO for food and feed use.

${ }^{43}$ Das Robert Koch-Institut https://www.rki.de/EN/Content/Institute/institute_node.html

${ }^{44}$ Das Bundesinstitut für Risikobewertung

https://www.bfr.bund.de/en/our mission statement-200291.html
} 
GenTG). However, "concert" is less than agreement. Therefore, an agreement does not need to be reached between the authorizing authority (BVL) and the cooperating-deciding authorities. Other federal authorities and the states (Länder) are merely consulted.

\subsection{Scientific Institute}

Considering the high-tech nature of GM technology and the fact that the capacities of administrative authorities for in-depth fact-finding and risk assessment for GMOs are limited, scientific institutions are entrusted with the responsibility for giving relevant professional, scientific assessments and recommendations. These are the Zentrale Kommission für Biologische Sicherheit (Central Commission for Biological Safety, abbreviated: ZKBS) and the European Food Safety Authority (EFSA).

\subsection{Release and Marketing of GMOs}

Pursuant to Art. 4 of GenTG, ZKBS is to give professional, scientific advice in the process of authorizing GMO releases and marketing within Germany. Likewise, when a member state or the European Commission raises any objection in case of an application for a marketing authorization, EFSA may have to be consulted by the Commission on the adverse effects of the relevant GMOs on human health and the environment (Art. 28 of Directive 2001/18/EC, for more information about EFSA see the following section).

The concept of the ZKBS, as well as its composition and tasks, are laid down in Art. 4 and 5 of GenTG. Besides, the Federal Government is empowered to supplement the GenTG, for instance, with regard to the appointment of members of ZKBS, its operating procedure, consultation of external experts, cooperation with the authorities, and so on. The members of the ZKBS are composed of expert persons representing various research disciplines and sectors of society. ${ }^{45}$ Twelve of all members shall have specific and preferably international

${ }^{45}$ Pottschmidt, Gentechnikrecht, in: Rehbinder \& Schink (eds), Grundzüge des Umweltrechts (5th edition), 2018, p. 1164. 
experience in the fields of microbiology, cell biology, virology, genetic engineering, plant breeding, hygiene, ecology, toxicology, and safety engineering. At least seven of these experts must work in the field of recombination of nucleic acids. Furthermore, each of the areas mentioned must be represented at least by one expert, and the field of ecology by at least two experts (Art. 4 GenTG). There are six ministries that are in charge of nominating the experts to constitute the $\mathrm{ZKBS}^{46}$. However, the decision-making authority, BVL, is not involved in the nomination of experts, which is more conducive to ensuring members' independence. One member shall also be appointed from each field of trade unions, occupational health and safety, business, agriculture, environmental protection, nature conservation, consumer protection, and research-promoting organizations. In fact, the ZKBS was initially conceived as a purely expert body when it was first established in 1979 by Guidelines for the Protection against Risks from in-vitro Recombinant Nucleic Acids. ${ }^{47}$ Considering that in order to cope with, on the one hand, scientific and technical progress, in particular, with information deficits of the competent authorities ${ }^{48}$, on the other hand, public concerns about the democratic legitimacy of the ZKBS and about possible conflicts of interest among its members, who themselves operate or carry out genetic engineering projects $^{49}$, ZKBS was expanded with the enactment of the GenTG to enroll knowledgeable persons who are to represent various areas of society, which enables a confrontation of the scientific-technical expertise with other points of view. The involvement of experts from multiple disciplines and social sectors aims to enable a comprehensive analysis of risks and neutralize possible biases of representatives of particular disciplines of science and practice. To a certain extent, it promotes "perspective pluralism" within the ZKBS. ${ }^{50}$

\footnotetext{
${ }^{46}$ These are respectively the Federal Ministry of Food and Agriculture (Bundesministerium für Ernährung und Landwirtschaft), Federal Ministry of Education and Research (Bundesministerium für Bildung und Forschung, Federal Ministry of Economics and Energy, Federal Ministry of Labour and Social Affairs (Bundesministerium für Wirtschaft und Energie, Bundesministerium für Arbeit und Soziales), Federal Ministry of Health (Bundesministerium für Gesundheit) and Federal Ministry for the Environment, Nature Conservation, Construction and Nuclear Safety (Bundesministerium für Umwelt, Naturschutz, Bau und Reaktorsicherheit). ${ }^{47}$ Pottschmidt, Gentechnikrecht, in: Rehbinder \& Schink (eds.), Grundzüge des Umweltrechts (5th edition), 2018, p. 1164.

${ }^{48}$ Spieker gen. Döhmann, Informationsgewinnung im Umweltrecht durch materielles Recht, DVBl 2006, p. 283.

${ }^{49}$ Reinhardt, Materielle Entscheidungsbefugnisse im Gentechnikrecht, Ein Beitrag zur Technikbewältigung durch Recht, NVwZ 2003, p. 1450.

50 Pottschmidt, Gentechnikrecht, in: Rehbinder \& Schink (eds.), Grundzüge des Umweltrechts (5th edition), 2018, p. 1164.
} 
In the process of deciding on releasing and marketing GMOs, the ZKBS is mandated to verify and assess applications with respect to safety-related issues caused by the use of GMOs, in particular the risk to the protected interests, and provide scientific advice to the Federal Government (Art. 4 of GenTG in connection with Art. 14 ZKBSV). In its recommendations, the ZKBS should also take due account of the state of international development in genetic engineering safety (Art. 5 sentence 2 of GenTG). According to the word "verify and assess the application" in Art. 16(5) of GenTG, it can be concluded that ZKBS can just conduct desk research. In other words, based on the individual members' knowledge, ZKBS only analyzes the data from the applicant for evaluating the associated risk. While this approach saves administrative resources, it is not conducive to better risk assessment.

Through clarifying the establishment, the composition, the appointment of its members, the tasks and procedures of the ZKBS, the objective of the GenTG and the ZKBSV is to ensure independence from instructions and neutrality of ZKBS members as well as the transparency of its procedure. ${ }^{51}$ However, according to Art. 3 of ZKBSV, members of ZKBS perform their duties on an honorary basis, which shows that the credibility and correctness of the risk assessment from ZKBS depend to a certain extent on the personal integrity of the individual expert. The expert bodies exert a considerable influence on the contents of the consent, which has been criticized as a disguised form of governance by expert bodies. ${ }^{52}$ Of course, although ZKBS's scientific opinions on projects have primarily influenced the decision-making practices of the BVL, this agency is empowered to make a decision that deviates from the opinion of ZKBS, but only where justified by rational grounds (Art. 10 in conjunction with Art. 16 of GenTG). It can be presumed that the legislature has wanted to take due account of the scientific uncertainty about GMO risks, thereby also acknowledging the necessity for the executive to weigh the benefits in making a deviating decision. From

\footnotetext{
${ }^{51}$ Pottschmidt, Gentechnikrecht, in: Rehbinder \& Schink (eds.), Grundzüge des Umweltrechts (5th edition), 2018, p. 1165.

52 Rehbinder, et al., Pharming, 2008, p. 222; Reinhardt, Materielle Entscheidungsbefugnisse im Gentechnikrecht, Ein Beitrag zur Technikbewältigung durch Recht, NVwZ 2003, p. 1446.
} 
a legal point of view, the ultimate responsibility is vested in the competent administrative authority. ${ }^{53}$

\subsection{Marketing of GMOs for food and feed use}

The European Food Safety Agency (EFSA) has a central role in risk assessment and thus for the authorization of GMOs for food and feed use (Art. 6 of Regulation 1829/2003). ${ }^{54}$ Art. 6 and 18 of Regulation 1829/2003 mandate EFSA to advise the European Commission on all issues of GM food and feed safety, acting as the risk assessor and risk communicator for providing food- and feed-related scientific advice, analysis of information, and risk communication service. ${ }^{55}$ In fact, it is an EU-wide comprehensive professional and independent institute with the notable task of providing all food- and feed-related scientific advice $^{56}$, covering GM food and feed. EFSA was established in 2002 with the adoption of Regulation (EC) No 178/2002 as an independent food- and feed-related scientific agency at a particular moment of heavy public distrust in the EU safety governance of the food chain. ${ }^{57}$ It is a specific embodiment of separating risk assessment from risk management to strip the political influence on the objective scientific opinion, ensure the scientific integrity of the risk assessment, and to reduce any conflict of interest, at last, to "regain the trust of EU citizens in the safety of the food they eat as well as in those responsible for protecting the public from food safety-related risks" ${ }^{58}$. Currently, EFSA is mandated to

\footnotetext{
${ }^{53}$ Administrative Court of Appeal Mannheim, NVwZ 2002, p. 224.

54 Thomas Schwabenbauer, Einführung in das Recht der grünen Gentechnik - unter Berücksichtigung aktueller Rechtsprechung, NuR 2011, p. 694.

55 Dreyer \& Renn, EFSA Stakeholder and Public Involvement Policy and Practice: A Risk Governance Perspective, in: Alemanno \& Gabbi (eds.), Foundations of EU Food Law and Policy, 2014, p. 171.

${ }^{56}$ Leone, EFSA under Revision: Transparency and Sustainability in the Food Chain, Yearbook of European Law, Vol. 39 (2020), p. 536.

${ }^{57}$ The political climate at the time was severely affected by many food safety scares across Europe, the most serious of which were mad cow disease and dioxin. The food crises and scandals raised concerns about the management, lack of transparency, openness, functioning and independence of the various responsible scientific committees involved in EU food governance. Besides, the competent authorities in some member states also did not deserve trust, which were not acting in a transparent form. This was the impetus that led to the demand for a food agency at the EU level that could function independently. Byrne, The Genesis of EFSA and the First 10 Years of EU Food Law, in: Alemanno \& Gabbi (eds), Foundations of EU Food Law and Policy Ten Years of the European Food Safety Authority, 2014, p.17; Chatzopoulou, Unpacking the Mechanisms of the EU “Throughput" Governance Legitimacy: The Case of EFSA, European Politics and Society, Vol. 16:2 (2015), 159.

58 Byrne, The Genesis of EFSA and the First 10 Years of EU Food Law, in: Alemanno \& Gabbi (eds), Foundations of EU Food Law and Policy Ten Years of the European Food Safety Authority, 2014, p.17
} 
"deliver independent, high- quality and timely scientific advice on risks", "communicating on its outputs and risks to the public", and "cooperating with the Member States and public bodies to foster a trusted food safety system in Europe" in an independent and transparent manner. ${ }^{59}$

After several adjustments, such as the 2009 Lisbon Treaty and the Regulation (EU) 2019/1381, a Management Board, Executive Director, an Advisory Forum, and a Scientific Committee with ten Scientific Panels compose the EFSA. ${ }^{60}$ The Management Board is an internal body running the EFSA and mandated to act in the public interest. ${ }^{61}$ The Scientific Committee consists of the chairs of the 10 Scientific Panels. Its core mission is to support and harmonize the work of the panels on scientific issues. Each of the ten panels is responsible for the bulk of EFSA's assessments in a different area of the food and feed chain. Among them, there is a GMO Panel, which is chiefly responsible for the GMO-related issues that fall within the remit of EFSA. In the process of authorizing GM food and feed, it is mandated to assess the risk and communicate the related information to the relevant institute and public. In general, members of the Management Board, the Scientific Committee, and Scientific Panels mainly comprise prominent scientists with expertise from across Europe. Their enrollments are primarily based on experience and expertise, other than on nationality, while ensuring the broadest possible geographic distribution within the Union. ${ }^{62}$ Besides, their nomination is independent of Member States nominations. ${ }^{63}$ The rationales for this are that the nomination of scientific members being de-politicized is

\footnotetext{
${ }^{59}$ Leone, EFSA under Revision: Transparency and Sustainability in the Food Chain, Yearbook of European Law, Vol. 39 (2020), p. 536.

${ }^{60}$ Chatzopoulou, Unpacking the Mechanisms of the EU "Throughput" Governance Legitimacy: The Case of EFSA, European Politics and Society, Vol. 16 (2015), p. 159.

${ }^{61}$ Management Board members of EFSA

See: https://www.efsa.europa.eu/en/people/mbmembers

62 Chatzopoulou, Unpacking the Mechanisms of the EU "Throughput" Governance Legitimacy: The Case of EFSA, European Politics and Society, Vol. 16 (2015), 159.

${ }^{63}$ Testori Coggi \& Deboyser, The European Food Safety Authority: A View from the European Commission, in: Alemanno \& Gabbi (eds.), Foundations of EU Food Law and Policy Ten Years of the European Food Safety Authority, 2014, p. 195. The management board of EFSA is appointed by the Council, in consultation with the European Parliament, but they must choose its members within a list of independent personalities presented by the Commission. Membership of the Scientific Committee and the 10 panels is renewed every three years. EFSA follows a detailed selection procedure that includes external evaluation. Advisory forum is made up of member state representatives.
} 
likely to contribute to ensuring that scientific advice is not unduly skewed by national interests, which may differ from wider EU interests, ${ }^{64}$ and professional expertise and independence are far more crucial for EFSA emphasized as an independent scientific institution. It is especially required that four of the Management Board members should be selected to stand for the consumers and other interests in the food chain for the sake of partly monitoring EFSA, but also to gain public trust. ${ }^{65}$ What is worth mentioning is that for the sake of ensuring the independence, impartiality, and reliability of scientific opinions, the Management Board members and members of the advisory forum are all required to make an annual declaration of interest, and the work of the experts in Scientific Panels, apart from the reimbursement of expenses, is unpaid. ${ }^{66}$

Conceived as a regulatory agency of 'assistance' or of 'pre-decision making in the process of food and feed decision-making, EFSA is not empowered to adopt measures with legallybinding effects. ${ }^{67}$ Despite that, its advice profoundly affects EU Commission's decisionmaking. Therefore, EFSA has continued to face controversies about its competencies and influence, such as its impartiality, independence, and reliability of scientific advice in foodrelated risks from commercial or political interests, ${ }^{68}$ particularly with regard to GM food and feed authorizing. For example, the fitness check of the EU food law completed in 2018 shows that, because the experts come from a few Member States only, it is difficult for EFSA to maintain a high level of scientific expertise. ${ }^{69}$ Due to a widespread skepticism on GMOs,

\footnotetext{
${ }^{64}$ Daviesp, The Consumers' Perspective of EFSA, in: Alemanno \& Gabbi (eds.), Foundations of EU Food Law and Policy Ten Years of the European Food Safety Authority, 2014, p. 263.

${ }^{65}$ Chatzopoulou, Unpacking the Mechanisms of the EU "Throughput" Governance Legitimacy: The Case of EFSA, European Politics and Society, Vol. 16 (2015), 159.

${ }^{66}$ Daviesp, The Consumers' Perspective of EFSA, in: Alemanno \& Gabbi (eds), Foundations of EU Food Law and Policy Ten Years of the European Food Safety Authority, 2014, p. 263. The

${ }^{67}$ Pintado, A Taxanomy of EFSA's Scientific Outputs, in: Alemanno \& Gabbi (eds), Foundations of EU Food Law and Policy Ten Years of the European Food Safety Authority, 2014, p. 29.

${ }^{68}$ Christiansen, \& Polak, Comitology Between Political Decision-Making and Technocratic Governance: Regulating GMOs in the European Union, EIPASCOPE 2009, p. 1.; Roth-Behrendt, A View of EFSA from the European Parliament, in: Alemanno \& Gabbi (eds), Foundations of EU Food Law and Policy Ten Years of the European Food Safety Authority, 2014, p. 235.

${ }^{69}$ European Commission, 'Commission Staff Working Document-Synopsis Report' SWD (2018) 97, p. 5; The same viewpoint was expressed by 27.7 per cent of citizens and 26.1 per cent of stakeholders that took part in an open public consultation (OPC) launched by the Commission from January to March 2018. Moreover, more than $80 \%$ of respondents from citizens and stakeholder groups consider that EFSA needs to be useful or very useful in selecting good and independent experts from a large pool of candidates, as well as their independence from risk managers (committees and member states) and industry.
} 
it can be concluded that EFSA has been at the heart of many fierce controversies on GMOs and related food as well as feed at the EU level. For example, the youngest diverging scientific opinions on GMO maize or potato caused uproars in many different Member States, which is a sign that EFSA still has a long way to go to guarantee the best state of science and consumer trust. ${ }^{70}$

The EU is, of course, constantly improving EFSA's composition, operating rules and procedures, and institutional cooperation. The most recent, profoundly influential Regulation (EU) 2019/1381 has brought significant innovations to EFSA's governance. The Regulation aims to increase the transparency of risk assessment in the food chain, strengthen the reliability, objectivity, and independence of the studies submitted to EFSA, and reinforce the governance of EFSA in order to ensure its long-term sustainability. ${ }^{71}$ For example, "to address the criticism that pinpointed how the absence of Member State representation led, in some cases, to decrease the acceptance of EFSA's work", ${ }^{72}$ as regards the Management Board of EFSA, this regulation provides that:

1. Each Member State shall nominate a member and an alternate member as its representatives to the Management Board. ...

la. In addition to members and alternate members referred to in paragraph 1 , the Management Board shall include (a) two members and two alternate members appointed by the Commission as its representatives, with the right to vote; (b) two members appointed by the European Parliament, with the right to vote; (c) four members and four alternate members with the right to vote as representatives of civil society and food chain interests, namely one member and one alternate member from consumer organizations, one member

\footnotetext{
See: $\quad$ https://ec.europa.eu/info/consultations/public-consultation-transparency-and-sustainabilityeu-riskassessment-foodchain_en ; Leone, EFSA under Revision: Transparency and Sustainability in the Food Chain, Yearbook of European Law, Vol. 39 (2020), p.549.

${ }^{70}$ Roth-Behrendt, A View of EFSA from the European Parliament, in: Alemanno\& Gabbi (eds), Foundations of EU Food Law and Policy Ten Years of the European Food Safety Authority, 2014, p. 238.

${ }^{71}$ Transparency of EFSA

See: https://www.efsa.europa.eu/en/about/transparency

72 Leone, EFSA under Revision: Transparency and Sustainability in the Food Chain, Yearbook of European Law, Vol. 39 (2020), p.550.
} 
and one alternate member from environmental non-governmental organizations, one member and one alternate member from farmers organizations, and one member and one alternate member from industry organizations.

1b. The members and the alternate members of the Management Board shall be nominated and appointed on the basis of their relevant experience and expertise in the field of food chain law and policy, including risk assessment, whilst ensuring that there is relevant expertise in the fields of managerial, administrative, financial and legal matters within the Management Board.

Except for EFSA, to assess the risk of GM food/feed, the Community reference laboratory has been set up. The specific tasks and duties of the laboratory are provided in the Annex of Regulation 1829/2003, including such matters as testing and verification of the applicant's proposed detection and identification methods, evaluating the data provided by the applicant, the receiving, preparing, storing, maintaining, and distributing to the members of the European Network of GMO laboratories of the appropriate positive and negative control samples, etc. Independent testing by laboratories is more conducive to providing more reliable and realistic information for decision-making bodies. Here, it appears that at the food and feed level, the EU takes a more cautious approach towards GMO risks and does not rely unilaterally on the applicant's information.

\subsection{Consulted Institutes}

\subsection{Release and Marketing of GMOs}

The Julius Kühn Institute (JKI) ${ }^{73}$, which is a Federal Research Institute for Cultivated Plants, shall be consulted by the BVL when making the decision. In the case of the release of genetically modified vertebrates or genetically modified microorganisms that are applied to

${ }^{73}$ The Julius Kühn Institute https://www.julius-kuehn.de/en/mission-and-mandate/ 
vertebrate animals, the Paul-Ehrlich-Institute $(\mathrm{PEI})^{74}$ and the Friedrich-Loeffler-Institute $(\mathrm{FLI})^{75}$ shall also be invited to make comments. Besides, the European Commission shall consult the Committee(s) on Ethics, such as the European Group on Ethics in Science and New Technologies, on ethical issues of a general nature (Art. 28 of Directive 2001/18/EC).

\subsection{Marketing of GMO for Food and Feed Use}

To obtain an opinion on ethical issues, the European Commission must consult the European Group on Ethics in Science and New Technologies or other Ethic institutes. (Art. 32 of the Regulation 1829/2003).

\subsection{Applicant}

\subsection{Release and Marketing of GMOs}

The safe handling of genetic engineering products requires that the relevant person conducts a comprehensive and correct assessment of possible risks according to the state of science and technology, implements appropriate safety measures, and applies for the relevant authorization. These are primarily the applicant group's tasks and responsibilities, who must have the necessary expertise and the necessary equipment. Relying on the precautionary principle, the GenTG and Directive 2001/18 have laid down a number of pertinent basic obligations of members of the applicant group. This group includes, besides the operator, also the Officer for Biological Safety (Beauftragter für die Biologische Sicherheit), and the project manager. ${ }^{76}$

\footnotetext{
${ }^{74}$ The Paul-Ehrlich-Institut https://www.pei.de/EN/institute/duties/duties-node.html

${ }^{75}$ Das Friedrich-Loeffler-Institut https://www.fli.de/de/ueber-das-fli/das-fli/

${ }^{76}$ Art. 3(7), (8), (9),

Operator refers to a legal or natural person or an unincorporated association of persons who constructs or operates a genetic engineering facility under their name, carries out genetic engineering work or releases or places products containing or consisting of genetically modified organisms on the market for the first time; if a licence has been granted in accordance with $\S 16$ (2), which in accordance with $\S 14$ (1) sentence 2 also permits the placing on the market of the progeny or the propagating material, only the licence holder is the operator in this respect.

Project Manager refers to a person who, within the framework of his or her professional duties, carries out the direct planning, management or supervision of genetic engineering work or a release,

Committee for Biological Safety refers to one person or a majority of persons (Biosafety Committee) who will
} 
Generally, the operator has a decisive influence on the construction and operation of a genetic engineering plant or can exercise decisive design options. The operator is the one who applies for the authorization and is the main person responsible for the operation of the activity. The project manager must have a direct and concrete relation to the respective project with the possibility of influencing its operation, on the one hand, and must meet the responsibility assigned to him, on the other hand. The Committee for Biological Safety shall monitor the fulfillment of the project manager's tasks and advise the operator.

In the process of authorizing GMOs for release or marketing, the applicant has an obligation of care, recording, and danger precaution. Concretely, the applicant is obliged to conduct a risk assessment, take appropriate precautionary measures, register the related information, report the updated information, appoint a committee for biological safety, and so on. Risk assessment and precautionary measures are critical in the process of authorizing the GMOs

Firstly, the applicant must carry out a case-by-case assessment of the GMO-associated risks for the legal interests listed in Art. 1(1) of GenTG, i.e., human life and health, material goods, and ecological interests (Art. 6(1) of GenTG in conjunction with Art. 4 of Directive 2001/18). Risk assessment is not defined in GenTG; however, Art. 2(8) of Directive 2001/18/EC can be relied on. It refers to evaluating risks to human health and the environment, whether direct or indirect, immediate or delayed, which the deliberate release or placing on the GMOs market may pose. This assessment shall be conducted in accordance with Annex II of Directive 2001/18/EC taking into account the environmental impact according to the nature of the organism introduced and the receiving environment. Besides, the information necessary to carry out the environmental risk assessment is laid down in Annex III. The fluid characteristics of risks must be taken into account here. Considering that risk will change over time, both the risk at present and the long-term or future risk shall be considered. All risks or potential risks shall be assessed. On the contrary, it can be presumed

verify the fulfilment of the tasks of the project manager and advise the operator. 
that the residual risk, which is not defined as "risk" or potential risk," is regarded as legally permissible.

Secondly, according to risk assessment and the state of the art in science and technology, the operator is also obliged to take the necessary precautionary measures (Art. 6(2) of GenTG). It is worth mentioning that the precautionary measures need to be protective of third parties, especially neighbors. ${ }^{77}$ The affected third parties can appeal to an administrative court against granting an authorization on the grounds of an incorrect risk assessment.

Furthermore, the risk assessment and the safety measures shall be reviewed at regular intervals. If there are reasonable grounds for believing that the risk assessment no longer reflects the latest scientific and technical knowledge, the risk assessment shall, in any case, be revised immediately, depending on the speed of scientific development. The specific requirements on the content of the obligation to carry out a risk assessment and precautionary measures are formulated in Art. 8 to 13 of GenTSV and Annexes III to V of GenTSV together with Annex II and Annex III of Directive 2001/18/EC. Therefore, the obligation of risk assessment and precaution is a kind of dynamic and continuous duty, which takes effect before being granted authorization and afterward, even beyond the cessation of the company's operation (Art. 6(2) of GenTG). Here again, the uncertain nature of GMO risk is reflected in the legislation. By requiring the applicant to update the risk assessment and adopt appropriate precautionary measures to adapt to the further development of knowledge, the applicant assumes the primary task of risk precaution. In contrast, the executive branch assumes the duty of surveillance, which is a relatively passive role. Without any doubt, the requirement that the applicant provides risk assessment information is also based on the assumption that the applicant may have easier access to relevant information and that administrative enforcement costs can be saved.

${ }^{77}$ Kauch, Gentechnikrecht, 2009, p. 132. 


\subsection{Marketing of GMOs for Food and Feed Use}

The obligations and rights of an applicant for a GM food/ feed authorization are similar to that applicable to GMO marketing, except for some subtle distinctions, such as submitting the methods for detection and tracking, samples of the food, etc.

\subsection{Public}

The public plays an important role in the relevant authorization procedures. The term generally refers to the people or groups interested in the grant or denial of an authorization, except the five groups mentioned above, i.e., competent authority, scientific institute, consulted institute, the applicant, including third persons affected by the GMO project or products, such as potentially injured parties or competitors, and even laypersons not directly affected. The public is entitled to participate in the hearing procedure and obtain relevant information. However, there are some differences with respect to releases and marketing of GMOs. (See 6.3.1.2)

\subsection{Release and Marketing of GMOs}

The public's right to know is laid down in Art. 4(4), 28a of GenTG, Art. 2 of GenTAnhV, Art. 9, 24, and 28(4) of Directive 2001/18/EC. Art. 4(4) of GenTG prescribes that the ZKBS shall report annually to the public in a general way about its work. Reports from professional bodies contribute to increasing the cognitive abilities of the population relating to GMOs and, to a certain degree, public acceptance of GMO authorizations. Art. 28a of GenTG specifically stipulates which kind of information shall be disclosed by the BVL, such as the final decision on the authorization, the reasonable suspicion of a danger to the legal interest mentioned in Art. 1(1), precautionary measures to be taken, the results of the monitoring of the placing on the market in a general manner. According to Art. 2 of GenTAnhV, in the process of authorizing GMO releasing, the competent authority, i.e., BVL, is mandated to publish the project information in its official publication and local daily newspapers distributed in the area in which the release applied for is to take place. 
Before taking a release decision, the publication of information by the executive is designed to get prepared for the subsequent hearing process and allow the concerned public to know whether their rights and interests may be affected. In accordance with Art. 24 of Directive 2001/18/EC and, concerning the confidential information of the applicant, EU Commission has been mandated to the public the summary of the notification of a release submitted by the competent authority of member states prescribed in Art. 11 of Directive 2001/18/EC, the assessment report of BVL, and scientific opinions. Besides, EFSA, if it is consulted, is also obliged to publish specific information, such as notifications, relevant supporting information, and any supplementary information supplied by the notifier, as well as its scientific opinions (28(4) of Directive 2001/18/EC).

In addition to the right to know, public participation is guaranteed by Art. 18 (2) of GenTG with respect to releases and Art. 24(1) of Directive 2001/18/EC with respect to marketing. Public participation is designed to channel public opinions to the competent authorities. In conjunction with Art. 18 (2) of GenTG, Art. 1(5) GenTAnhV provides that a hearing is required prior to an authorization for a release, excluding the marketing authorization. The details of the hearing procedure are specified in GenTAnhV. A hearing procedure must be carried out before a decision is taken on the approval of a release. However, not everyone has the opportunity to participate in the hearing process, even though the assertion of particular individual harm is not necessary. Only those persons have standing who have objected to the concerned project within a defined period, and this only with respect to the contents of their objections. (Art. 18(3) in conjunction with Art. 5(1) GenTAnhV In other words, the public can raise objections freely; however, if the objections have not been raised before the expiry of the objection period, they are irrelevant in the authorization proceeding, especially need not be discussed in the subsequent hearing. Admittedly, if the objections are related to subjective rights, they will play a role at the level of the judicial control. Overall, on the one hand, such hearing provisions can improve the efficiency of administrative decision-making, but, on the other hand, significantly limit the possibilities for public participation. In addition, in the process of marketing authorization, the public is entitled to make comments under EU law (Art. 24 of Directive 2001/18). Technically, this 
public participation takes place on the internet.

\subsection{Marketing of GMOs for Food and Feed Use}

In order to fully respect the public's right to know, Regulation (EC) No 1829/2003 also provides that specific documents submitted by the applicant, the EFSA scientific opinion, opinion of the Ethics Committee, etc., shall be made available to the public. (like under Art. 28 and 29 of the Directive 2001/18). Besides, there is also an opportunity for the public to express their opinion on the scientific opinion of EFSA via the internet (Art. 6(7) and 18(7) of Regulation (EC) No 1829/2003)

\subsubsection{Procedure}

\subsection{Release of GMOs}

The authorization of release of GMOs falls under the member states' competence according to the Directive 2001/18; hence, the procedure is initiated by the member state and ends there. Generally speaking, there are four stages of the whole decision-making process: application, consultation, risk assessment, as well as risk management (making a decision). Directive 2001/18 also lays down a simplified differentiated procedure. The relevant Art. 7 is transposed in Art. 14(4a) of GenTG. It applies where sufficient experience has been gained from the released GMOs. The procedure mainly covers repeated or parallel releases of the same GMO. Although it has significant importance in practice, it will not be further discussed here.

\subsection{Application Stage}

First of all, the notifier shall submit a written request of application for releasing a GMO in accordance with standard data formats ${ }^{78}$, enclosing the documents prescribed in Art. 15(1)

\footnotetext{
78 The format requirements for the submission were provided in Art.6(2a) of Directive 2001/18 inserted by Regulation (EU) 2019/1381.
} 
of GenTG in conjunction with Art. 5 of GenTVfV together with Art. 6(2) of Directive $2001 / 18^{79}$, in particular, risk assessment and safety measures envisaged, to the competent authority, i.e., BVL in Germany. The BVL shall then examine whether the application contains all information necessary for the release's risk assessment. If the information provided is insufficient, the applicant is required to provide further information.

Once the BVL has received the notification and acknowledged the date of receipt, there are two tasks and limited periods of time concurrently activated: firstly, 30 days for information within which BVL shall convey the summary of the application documents in a designated format ${ }^{80}$ to the EU Commission (Art. 16(6) GenTG); secondly "90 days for a decision, within which BVL shall make a written decision responding to the notifier on whether the release will be permitted or not (Art. 16(3) GenTG). Of course, the period of 30 days for information and 90 days for a decision will be suspended in the case that the notifier did not supply the qualified documents and BVL muss waits for the supplement of materials.

In addition, within the 90 days for a decision, BVL is obliged to forward the application together with the necessary documents to ZKBS and related authorities whose competencies are expected to be affected, enclosing a reasonable time limit for the authorities to submit their comments to BVL (Art. 9 (1) GenTVfV), as well as consult the public (Art. 9 of Directive 2001/18). Due to the hearing procedure, the 90 days for a decision period can be extended no more than 30 days, i.e., extended to "120 days for a decision," according to Art. 16(3) of GenTG.

\footnotetext{
79 Annexes III, IIIA, IIIB, IV of Directive 2001/18/EC provide detailed rules on the information that shall be submitted.

${ }^{80}$ Art. 1(1) of GenTBetV in conjunction with Art. 11(1) prescribes that the summary of application documents shall be submitted to EU commission in the designed form in the designed form. The formatted is specified in Council Decision of 3 October 2002 establishing, pursuant to Directive 2001/18/EC of the European Parliament and of the Council, the summary notification information format for notifications concerning the deliberate release into the environment of genetically modified organisms for purposes other than for placing on the market.
} 


\subsection{Consultation Stage}

To safeguard the interests of the EU Member States not involved in the releasing procedure, Directive 2001/18/EC provides for a Community-wide participation procedure for the release, which has been transposed in Art. 16(6) GenTG and GenTBetV. After receiving the summary of the application, the EU Commission shall forward the documents to other member states and Contracting States within 30 days (Art. 11(2) of Directive 2001/18/EC and Art. 1(1) of GenTBetV). Once relevant states are informed about applications for release from Germany, they may also express their observations, if they have, within 30 days and submit them to the EU Commission or the BVL. Therefore, BVL can also consider comments submitted by the Member States and the other Contracting States when making the decision (Art. 1(2) of GenTBetV). However, since the release of GMOs is more local and limited to designated areas, the competent authority, i.e., BVL, possesses the final decisionmaking power if the release area is located in Germany.

In addition to consulting the EU, Art. 18 (2) of GenTG and stipulates that a hearing procedure must be carried out before a decision is made on an approval of a release. In order to implement the procedure for consulting the public, the information concerning the release project, respecting the EU confidentiality requirements ${ }^{81}$, shall be published by the BVL in the Federal Gazette and local daily newspapers, where GMOs are intended to be released. (Art. 2 and 3 of GenTAnhV in conjunction with Art. 9(2), Art. 25 of Directive 2001/18/EC) The application and the documents, such as the place and period for obtaining

\footnotetext{
${ }^{81}$ Article 25(3) of Directive 2001/18/EC, which is inserted by the recent Regulation 2019/1381, enumerates in more detail the types of confidential information to avoid generalisation or expansion of confidential information, namely: (a) items of information referred to in points (a), (b) and (c) of Article 39(2) of Regulation (EC) No 178/2002; (b) DNA sequence information, except for sequences used for the purpose of detection, identification and quantification of the transformation event; and (c) breeding patterns and strategies.

The clear provision on confidential information is intended to safeguard the legitimate rights and interests of the applicant on the one hand, and to ensure the maximum reasonable and effective disclosure of GMO information on the other, which is a balance between public and private interests. At the same time, in order to safeguard public health and safety, Article 25(7) of Directive 2001/18/EC creates exceptions to this balance, namely (a) where urgent action is essential to protect human health, animal health or the environment, or (b) where (the information) forms part of the conclusions of the scientific outputs delivered by the relevant Scientific Committee(s) or the conclusions of the assessment reports and which relate to foreseeable effects on human health, animal health or the environment, the related information shall nevertheless be made public, even if it meets the requirements for confidential information.
} 
access to the project information, the date fixed for raising objections, shall be made available for inspection one month after publication. In the case of release, if necessary, BVL can introduce and explain some information to the public at a suitable location close to the site of the facility or in the municipality where the release is planned (Art. 4 of GenTAnhV), such as the presentation of the possible safety-relevant effects on humans and the environment, report of risk assessment and envisaged precautionary measures, etc. This procedure is not mandatory for BVL.

Anyone may raise objections within one-month BVL has introduced and explained or after the publication of the application documents. The objections have to be substantiated and submitted to the decision-maker in written form (Art. 5 of GenTAnhV). However, a hearing meeting is not mandatory for the release authorization (Art. 11 of GenTAnhV). A hearing process is expected to facilitate gathering information on risks and identifying affected interests. Of course, it also has the function of education to improve the public's acceptance of GMO decisions., even though this is not necessarily the case.

\subsection{Assessment Stage}

As soon as the ZKBS has received the documents from BVL, they shall verify and assess safety-relevant questions, such as the necessary safety measures, and provide corresponding suggestions to the BVL (Art. 16(5) of GenTG and Art. 1(1) of ZKBSV). Furthermore, ZKBS is assigned to deliver opinions to BVL in accordance with ZKBSV, particularly whether the health of humans, the environment, or material goods could be endangered by the planned release (Art. 2(2) of ZKBSV). According to Art. 14 of ZKBS, the suggestion or opinions shall be presented to BVL within six weeks" If the applicant is required to supplement documents, the period can be extended.

Regarding the procedural requirement for the members of ZKBS to adopt a final resolution on the planned release of GMOs, i.e., the opinion or suggestion in the name of ZKBS to BVL, it is mainly specified in Art. 9, 10, 11, and 12 of ZKBSV. In order to reach a final 
resolution, all members have to be invited. A quorum for the meeting is at least ten members with voting rights representing at least six members with voting rights according to Art. 4 (1) sentence 2 No. 2 of Gen TG, i.e., working in the field of recombination of nucleic acids. In the decision-making process of ZKBS, minority views are respected and protected. Those members who vote against the final resolution of ZKBS can express a "minority vote." However, the "minority vote" shall meet the requirement that the member rejects the opinion as a whole and that the subject of the minority vote has been introduced into the discussion in the form of a motion. It has to be justified by indicating the individual considerations on which the rejection of the opinion is based (Art. 11(3) of ZKBSV). There are several other provisions worth mentioning. Firstly, the federal ministries who nominate the members of ZKBS together with BVL have the right to send representatives to attend the meetings of ZKBS (Art. 4 (1)). Secondly, if the ZKBS permits, the applicant or expert delegated by the applicant can give some verbal introductions and explanations to ZKBS (Art. 4(2)). Thirdly, to carry out its tasks, the ZKBS may hear experts, take expert advice, have a third party conduct an investigation, or delegate specific tasks to individual members or alternates (Art. 7 of ZKBSV). The participation of these three groups in the ZKBS's decision-making process can, in part, increase the information available to it and secure a balanced decision.

\subsection{Risk Management Stage}

After consultation of the EU Commission and the member states (Art. 11(2) of Directive 2001/18), other authorities whose competence is affected, the authorities of the states (Länder), the public, and ZKBS, the BVL is responsible for consulting the JKI and FLI (Art. 16(4), (5) in conjunction with Art. 10(7) of GenTG). At last, it makes a decision on the release of the GMO in concert with the cooperating decision-making authorities, i.e., BfN, BfR, and RKI, within 90 days or "120 days, depending on the hearing procedure.

When deciding on the application, the BVL can appropriately take into account, in addition to its assessment, the scientific opinion of the ZKBS, the opinions of the related authorities 
and the JKI, as well as the FLI, comments, and suggestions from other EU Member States (Art. 1(2) of GenTBetV). Most importantly, it shall examine whether unacceptable adverse impacts on humans, animals, or the environment are to be expected and whether and which kind of necessary safety measures have to be taken. More information on the relevant criteria has been presented in section 6.2.1.1.

In the end, the final decision on whether the release can proceed lies with BVL (Art. 6(5) of Directive 2001/18/EC). If the competent authority deviates from the opinion of the ZKBS in its decision, it shall state the reasons for this in writing. After that, the final decision shall be communicated to relevant groups.

\subsection{Marketing of GMOs}

Compared with the release for GMOs, the marketing authorization ing procedure is far more complicated as it may involve an EU comitology procedure..$^{82}$ To a certain extent, decisions on releases are just domestic decisions. By contrast, the marketing decision is more supranational in that other member states, and the EU Commission play a meaningful role in the procedure. Generally, the whole decision-making process consists of five stages: application, domestic assessment report, EU procedure, public participation, comitology, as well as risk management.

\subsection{Application Stage}

The same as in the case of releasing, the notifier shall submit the notification with the necessary materials ${ }^{83}$ to the BVL. Risk assessment, safety measures envisaged, a proposal for

\footnotetext{
${ }^{82}$ Comitology is provided in Regulation (EU) No 182/2011 of the European Parliament and of the Council of 16 February 2011 laying down the rules and general principles concerning mechanisms for control by Member States of the Commission's exercise of implementing.

83 The requirements for the application documents are provided in Art. 15(3) of GenTG in conjunction with Art. 6 of GenTVfV together with Art. 13(2) of Directive 2001/18. Besides, the format requirements for the application materials were provided in Art. 13 (2a) of Directive 2001/18. For detailed standard data formats see footnote 69 in this Chapter.
} 
GMO labeling with a GMO unique identifier ${ }^{84}$, and packaging are required. After having received the qualified documents, BVL has to forward the summary of the application documents ${ }^{85}$ to the EU Commission and ZKBS at once. The summary of the application documents shall be passed to other member states and Contracting States and made available to the public within 30 days for consultation, respecting the EU Commission's confidentiality requirements ${ }^{86}$ (Art. 15, 24, 25 of Directive 2001/18). Besides, a copy of the whole application documents shall be sent to the EU Commission. Since the marketing authorization is valid on the entire Common Market, the EU participation procedure must be carried out before a decision is taken. A product authorized in another EU Member State in accordance with the Release Directive does not require a new authorization in Germany for distribution.

Once having received the applicant's notification, BVL is responsible for preparing an assessment report with BVL's standpoint indicating whether the marketing authorization can be granted or not within 90 days (Art. 16(3) of GenTG). Similar to the application stage in authorizing releases, in calculating the deadline of 90 days, no account shall be taken of the periods during which the notifier did not supply the qualified documents, and BVL must wait for the supplementation of materials. When the notification documents are qualified, BVL shall communicate the designated documents ${ }^{87}$ to the EU Commission without delay, which is obliged to forward them to other member states and Contracting States within 30 days (Art. 3(1) of GenTBetV in conjunction with Art. 13(1) of Directive 2001/18/EC). Besides, prior to the final decision, if new information becomes available regarding the risk of the GMO to human health or the environment, the notifier shall immediately take the necessary measures to protect human health and the environment and inform the competent authorities accordingly.

\footnotetext{
84 The rules for the unique identifiers of GMOS are laid down in Commission regulation No 65/2004.

85 Art. 3(3) of GenTBetV in conjunction with Art. 13(2)(h) prescribes that the summary of application documents shall be submitted to EU commission in the designed form. The format is specified in Council Decision of 3 October 2002 establishing, pursuant to Directive 2001/18/EC of the European Parliament and of the Council, the summary notification information format for notifications concerning the deliberate release into the environment of genetically modified organisms for purposes other than for placing on the market. ${ }^{86}$ About the confidential information see footnote 72 in this Chapter.

${ }^{87}$ It is by Art. 13(2)(h) of Directive 2001/18/EC.
} 


\subsection{Domestic Assessment Report Stage}

Within 90 days for the assessment report, before finalizing the assessment report, BVL shall forward the application and the necessary documents to ZKBS, cooperating decisionmaking authorities, and related authorities whose competencies are expected to be affected, enclosing a reasonable time limit for them to present their comments to BVL (Art. 9 (1) of GenTVfV).

After ZKBS has received the documents, in the same way as in the assessment stage as in the releasing process, ZKBS fulfills the task of verifying and assessing safety-relevant questions and providing corresponding suggestions to the BVL (Art. 16(5) of GenTG and Art. 1(1) of ZKBSV). In addition, BVL shall invite the JKI, FLI, and PEI to make comments ${ }^{88}$. Finally, just like the risk management process of authorizing releases, BVL finalizes the assessment report in concert with BfN, BfR, and RKI (Art. 10, 16 of GenTG), taking the comments and suggestions received into consideration. The guiding requirements of the content of the assessment report have been laid down in Annex VI of Directive 2001/18/EC. Thereafter, the written assessment report shall be communicated to the applicant.

\subsection{EU Procedure and Public Participation}

When the BVL intends to grant approval for the marketing, the assessment report and the information on which it is based shall be sent to the EU Commission within 90 days from the date of receiving the application. When the BVL intends to deny the approval, the same documents shall be communicated to the EU Commission within 15 days after informing the applicant of the assessment report at the earliest and within 105 days from the date of receiving the application at the latest, unless the application is withdrawn before the assessment report is sent to the EU Commission (Art. 3(1) of GenTBetV). When having

\footnotetext{
${ }^{88} \mathrm{It}$ is only in the case of the release of genetically modified vertebrates or genetically modified microorganisms which are applied to vertebrate animals, that FLI and PEI will be consulted.
} 
received the assessment report, the EU Commission shall circulate it to other member states within 30 days.

Furthermore, the assessment report shall be published by the EU Commission. Within 30 days, the public can express their opinion to the EU Commission, which forwards the relevant statements to BVL. However, the GenTG has not provided any access for the public to express their opinion on the marketing of GMOs to the competent authority during the process of preparing the assessment report; instead, public participation only takes place at EU level s (Art. 24 of Directive 2001/18/EC).

During the following 60 days since the date of circulation of the assessment report, the EU Commission, member states, or the Contracting States can make comments, ask for further information or raise reasoned objections against the standpoint of BVL to the Commission (Art. 15(1) of Directive 2001/18/EC). The EU Commission shall circulate the opinions both supporting and objecting it has received to all other competent authorities of member states, including BVL (Art. 15(2) sentence 2 of Directive 2001/18/EC). When reasoned objections have been raised by the EU Commission, member states, or the Contracting States, BVL at the domestic level shall forward the objections to the cooperating decision-making authorities and discuss with them (Art. 3(3) sentence of the GenTBetV). Besides, at the EU level, BVL is also responsible for entering into negotiations on any outstanding issues with the body concerned with the aim of reaching an agreement within 105 days since the circulation of the assessment report (Art. 3(2) of GenTBetV in conjunction with Art. 15(1) sentence 3 of Directive 2001/18). The EU Commission shall consult EFSA on its own initiative or at the request of a member state regarding GMO risks to human health or the environment (Art. 28(1) of Directive 2001/18/EC). During the last 45 days of the 105 days period for reaching an agreement, any time consumed waiting for further information, documents, or samples from the applicant, will not be counted into the last 45 days period".

The subsequent procedure differs according to the standpoint of BVL and the outcome of the consultation process. If BVL intends to reject the application, it can do so in spite of 
existing objections (Art. 15(2) of Directive 2001/18). If no objection has been raised within 60 days or an agreement has been reached within 105 days after distributing the assessment report, BVL is to grant the authorization or make the final decision in compliance with the agreement (Art. 15(3) of Directive 2001/18, Art. 3(3) sentence 3 of GEnTBetV). If BVL wants to approve the application in the absence of an agreement, the authorization process will continue, and the comitology procedure will be initiated.

\subsection{Comitology Procedure}

When the 105 days period for reaching an agreement has run out, and no agreement can be reached, BVL shall inform the EU Commission without delay; then, a 120 days period to make a final decision within the comitology procedure ${ }^{89}$ will start. This committee-based decision-making procedure requires the Commission to submit a draft decision to the Comitology Committee, which will give an opinion on whether it agrees or not with the Commission's draft decision. If the Committee reaches an agreement by a qualified majority, either approving or rejecting the marketing authorization, it has to be implemented by the BVL (Art. 30(2) of Directive 2001/18/EC in conjunction with Art. 5 of Regulation (EU) No 182/2011, Art. 3(4) and (6) of GenTBetV). If the Committee delivers no agreement, the EU Commission may summon an Appeal Committee (Art. 6 of Regulation (EU) No 182/2011). If the Appeal Committee fails to reach an opinion by a qualified majority, the EU Commission may decide on the application. However, this is not true where the Committee rejects the Commission proposal by a qualified majority. Depending on the type of procedure, the Committee may ultimately be able to block the Commission and prevent the Commission from adopting a decision. Before 2011, this in some cases meant that the Council of Ministers could adopt a decision instead of the Commission. ${ }^{90}$

\footnotetext{
${ }^{89}$ The Comitology procedure originally was regulated in Directive 1999/468/EC, which, however, has been repealed and superseded by Regulation (EU) No 182/2011 of the European Parliament and of the Council of 16 February 2011 laying down the rules and general principles concerning mechanisms for control by Member States of the Commission's exercise of implementing powers.

${ }^{90}$ van Asselt \& Vos, EU Risk Regulation and the Uncertainty Challenge, in: Roeser, et al (eds), Handbook of Risk Theory, 2012, p. 1120-1138.
} 
In fact, due to strong divergencies of opinion about the risks presented by GMOs among the member states, qualified majorities are difficult to achieve, whether positive or negative ones. Therefore, in the recent practice, some of the relevant decisions had ultimately to be made by the Commission. Since the Commission was not eager to always assume political responsibility for authorizing highly controversial green GMOs, a more recent amendment introduced an "opt-out" possibility for member states. According to Art. 26b (1) and (2) of Directive 2001/18 as inserted by Directive (EU) 2015/412, if the assessment report consenting to the marketing of GMOs includes their cultivation, member states are entitled to demand that the geographical scope of the written authorization be adjusted to the extent that all or part of the national territory is to be excluded from cultivation (whereas marketing and other uses remain permissible). The applicant may adjust its application accordingly or reject it, i.e., confirm the original scope of application of the relevant agricultural GMOs. If the applicant for the authorization refuses to agree to the adjustment, the Commission may grant the adjustment when there are "compelling grounds" for the opt out.

\subsection{Risk management stage}

After the procedures above, a written decision on the application shall be made within 30 days. During this 30-days period, the BVL shall first consult the JKI and BfK on the marketing application. Then, BVL shall make its final decision collaborating with the BfN, the BfR, and the RKI, and communicate the final decision to the EU Commission. However, when the marketing application has been dealt with in the comitology procedure and a decision been achieved, the BVL can only transpose the decision of the comitology committee, appeals committee, or Commission into a German decision (Art. 18(2) of Directive 2001/18/EC, Art. 3(4) and (6) of GenTBetV).

In case that the authorization can be granted, a written decision shall be issued, which explicitly specifies certain information according to Art. 19 of Directive 2001/18/EC, such as the scope of the consent, the unique identifier, a period of validity of the consent, 
condition of use, handling and packaging of the $\mathrm{GMO}(\mathrm{s})$, and so on. Above all, without prejudice to the applicant's confidentiality, the final decision, no matter whether positive or negative, any other launched risk assessment report and the EFSA scientific opinion shall be made available to the public (Art. 24 of Directive 2001/18/EC).

\subsection{Marketing of GMOs for Food and Feed Use}

Regulation (EC) No 1829/2003 on genetically modified food and feed lays down a procedure for issuing authorizations for the placing on the market of genetically modified food and feed as well as for cultivation for the production of food and feed. Since the procedures on food and feed are the same, this section introduces them together. According to the content of the relevant activities, the decision-making process can be divided into three stages: application, assessment, and decision-making including comitolgy.

\subsection{Application Stage}

First of all, the applicant shall present an application with the prescribed necessary documents in accordance with standard data formats ${ }^{91}$ to the competent national authority, i.e., BVL if submitting in Germany (Art. 5(3) and Art. 17 (3) of Regulation (EC) No 1829/2003). The application must clearly define the application's scope, contain studies and data demonstrating the safety of the product, indicate which parts are confidential, and include a monitoring plan, a labeling proposal, a detection method, etc. Among the documents of special significance are the proposal for labeling, monitoring plan, detection methods, sampling, identification of the transformation event, samples of the food and their control sample, and a summary of the dossier. Besides, if food/ feed contains or consists of GMOs, a risk assessment according to Annex II of Directive 2001/18/EC is indispensable. Then, BVL shall check whether the application contains all information necessary. ${ }^{92}$ If all

\footnotetext{
${ }^{91}$ The standard data formats are provided in Art. 39f of Regulation (EC) No 178/2002 pursuant to Art. 5(3) and Art. 17 (3) of Regulation (EC) No 1829/2003.

${ }^{92}$ According to the new requirement in Art. 5(3) I of Regulation (EC) No 1829/2003 as inserted by Regulation 2019/1381, the information that the applicant requests to be treated as confidential shall be accompanied by verifiable justification. This new requirement in conjunction with the information publication and confidentiality provisions, i.e., Art. 6 (7), Art. 30 of Regulation (EC) No 1829/2003, Art. 39 to 39e of Regulation
} 
necessary documents are submitted, BVL shall acknowledge receipt of the application and then deliver all relevant documents to the EU authority, i.e., EFSA; if not, the applicant has to supplement it.

\subsection{Scientific Assessment and Cooperation Stage}

After receiving the documents, EFSA shall inform the EU Commission and other member states as well as forward them the application and related materials without delay (Art. 5 of Regulation (EC) No 1829/2003). The summary of the dossier without confidential information shall be made available to the public by EFSA (Art. 5(2)(b)(iii) of Regulation (EC) No 1829/2003). Although EFSA is not the competent authority making the final decision, it plays a vital role in organizing the whole authorization process.

In addition to the routine work and daily operations, such as publishing information, exchanging the documents among member states since the date of receipt of the application, EFSA is commissioned to provide a scientific opinion relevant to the risk of concerned GM food/ feed to the environment and human and animal health. It is assisted by member states as well as the Community reference laboratory (Art. 6 of Regulation (EC) No 1829/2003). The assessment report shall be finalized within six months as far as possible.

While preparing the scientific opinion, EFSA is first obliged to verify whether all necessary application documents are provided and examine whether the food/feed concerned complies with the material criteria set out in Art. 4(1) of Regulation (EC) No 1829/2003, such as whether it has adverse effects on human health, animal health, or the environment (Art. 6(3)(a) of Regulation (EC) No 178/2002). If necessary, it can request the notifier to supplement additional information within a specific time limit. Any time spent waiting for additional information from the applicant is not counted into "six months" period for preparing a scientific opinion. EFSA is entitled to request the appropriate food/feed

(EC) No 178/2002, to a certain extent ensures the maximum reasonable disclosure of GM information and prevents the applicant from avoiding disclosure of information by means of claiming confidentiality. 
assessment body in accordance with Art. 36 of Regulation (EC) No 178/2002 and the competent authority of a member state in accordance with Art. 4 of Directive 2001/18/EC to conduct a safety assessment and an environmental risk assessment respectively (Art. 6(3)(b), (c) of Regulation (EC) No 1829/2003). However, when the GMOs concerned are to be used as seeds or other plant-propagating material, EFSA is obliged to ask a member state's competent authority, such as BVL in Germany, to carry out the environmental risk assessment. Besides, EFSA has other obligations. For example, it shall forward methods and samples referred to in Art. 5(3)(i) and (j) to the Community reference laboratory, which shall test and validate the method of detection and identification (Art. 6(d)). In case that the relevant food/feed is, contains or consist of GMOs, EFSA shall also take environmental safety requirements into consideration, assess the risk to human and animal health and the environment referred to in Directive 2001/18/EC, ensure that the safety measures are appropriate, and consult the competent authority of member states responsible for authorizing the releasing and marketing GMOs, such as BVL in Germany, which is obliged to respond within three months after the date of receiving the request.

After fulfilling the above obligations, EFSA has to finalize its opinion. If EFSA agrees with authorizing GM food/feed, it shall make public its opinion excluding confidential information of the applicant in the EFSA Journal ${ }^{93}$. Then, public participation starts in the form of making comments within 30-days to the EU Commission (Art. 6(7) of Regulation (EC) No 1829/2003).

\subsection{Decision-making and Comitology Stage}

Within three months following receipt of EFSA's opinion, the Commission shall prepare a draft implementing decision granting or refusing authorization (Art. 7(1) of Regulation (EC) No 1829/2003). Apart from taking due account of the EFSA's opinion, the Commission is also obliged to respect any relevant provisions of EU law and take into account other

\footnotetext{
${ }_{93}$ According to Art. 6(7) of Regulation (EC) No 1829/2003, which has been revised by Regulation 2019/1381, the confidential information shall satisfy the requirements provided in Art. 30 of this Regulation and Art. 39 to 39e of Regulation (EC) No 178/2002.
} 
legitimate factors relevant to the matter under consideration. ${ }^{94}$ The Commission may diverge from EFSA's opinion, but it must then justify its position. When assessing and evaluating GM food/feed and determining whether a GMO is different from its conventional counterpart, i.e., identifying the "substantial equivalence" 95 between GMOs and its conventional counterpart, "natural variations" must be taken into consideration (Art. 5(3)f and 17(3)f of Regulation (EC) No 1829/2003). After that, the Commission's draft decision shall be submitted to a committee constituted of national representatives, i.e., the Standing Committee on Plant, Animals, Food and Feed (Art. 7(3) and 35(1) of Regulation (EC) No 1829/2003). The follow-up procedure is called Comitology, which is the same as the one in the marketing authorizing procedure for GMOs and detailed requirements of which are provided in Regulation (EU) No 182/2011. In a nutshell, the Committee is mandated to reach an agreement on the Commission's draft decision within three months.

When the Standing Committee approves the Commission's proposal by a qualified majority within the designed period, the final decision to be made by the Commission shall be in line with the agreement. If not, the Commission may summon an Appeal Committee. In case that the Standing Committee or Appeal Committee reaches an agreement with a qualified majority, this is the final decision. When the Appeal Committee fails to reach an opinion by a qualified majority, the Commission may assume responsibility for the final decision (Art. 7(3), 35(2) in conjunction with Art. 5 and 6 of Art. 5 of Regulation (EU) No 182/2011). The decision shall then be communicated to the applicant without delay and published in the Official Journal of the European Union.

\footnotetext{
${ }_{94}$ General Court, TestBioTech eV and Others v European Commission, Case T-177/13, ECLI:EU: T:2016:736 Paragraph 100.

${ }^{95}$ Regarding the principle of substantial equivalence in assessing GM food/feed, the Commission held that it is a "key step in the safety assessment of food and feed derived from biotechnology and that the strategy was considered the point of departure for safety assessment. All differences arising from the genetic modification would then be the subject of an in-depth examination with respect to possible toxicological, allergenic or nutritional aspects." The substantial equivalence is identified through two steps: firstly, detect the statistically significant difference of the GM plant by comparing the GM plant with its comparator; secondly, evaluate the detected statistically significant difference of the GM plant against the values derived from the set of nongenetically modified commercial reference varieties planted in the same field trial to assess its biological relevance. See: General Court, TestBioTech eV and Others v European Commission, Case T-177/13, ECLI:EU: T:2016:736 Paragraph 186.
} 


\subsubsection{China}

\subsubsection{Participants in the Procedure}

\subsection{Competent Authority}

The framework of competent administrative authorities on GMO governance generally corresponds to the legislative framework of GMO law in China (see the following table). ${ }^{96}$

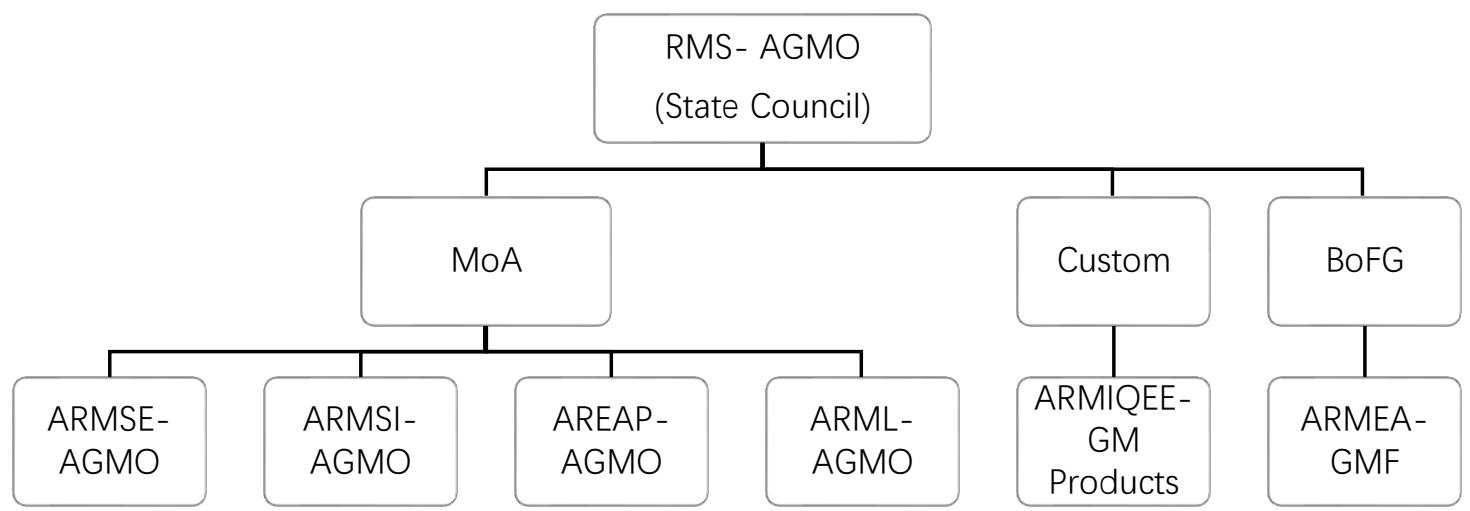

According to Art. 4 of RMS- AGMO and Art. 4 of ARMEA-GMF, MoA and BoFG are designated as the leading competent authorities responsible for nationwide managing agricultural GMOs and GM forest trees, respectively. Considering that the responsibilities imposed on MoA and BoFG are the same, the following section will take MoA as an example to introduce the competent authority.

Overall, in order to safeguard human health and the safety of animals, plants, and microorganisms, protect the ecological environment, and promote agricultural GMO research, MoA is in charge of the authorization of GMOs, supervising and inspecting relevant operations relating to agricultural GMOs, and cooperating with other ministries. In performing its supervisory and inspection duties, MoA is authorized to take a number of

\footnotetext{
${ }^{96}$ China's administrative system, at the vertical level, is composed of four levels of governments: State Council, provincial, municipal and township, each of which, except the township, is empowered specific legislation power. For instance, in order implement the RMS- AGMO, Agricultural Authority has enacted administrative regulations, such as ARMSE-AGMO, ARMSI-AGMO etc. At the horizontal level, with the exception of township governments, all other levels of government are composed of dozens of functional departments, such as, various ministries under the State Council.
} 
measures, such as (1) inquiring the units and individuals, interested parties relating to the research, testing, production, processing, operation, or import and export of agricultural GMOs, and requesting them to supplement materials or other information related to agricultural GMO safety, (2) ordering units and individuals that violate the rules of the safety management of agricultural GMOs to stop their illegal activities, (3) in case of emergency, sealing or seizing agricultural GMOs that are illegally researched, tested, produced, processed, operated, imported or exported, etc. (Art. 16 of ARMSE-AGMO).

In the process of authorizing GMOs and related activities, MoA has the primary responsibility for safety assessment in the manner of, firstly, assigning the internal scientific institute, i.e., Safety Committee for Agricultural GMO ( abbreviated as Safety Committee), the task to conduct a comprehensive safety assessment case by case according to ARMSEAGMO, secondly for commissioning qualified professional inspecting organizations to conduct an independent inspection of the relevant agricultural GMOs. Despite that, the applicant is required to submit an assertion of the safety level of GMOs and relevant information demonstrating it. However, the duty of carrying out a safety assessment is to determine the risk as well as the safety level of the relevant GMOs in accordance with Art. 9-14 of ARMSE-AGMO is imposed on MoA. This is similar to the obligation of risk assessment imposed on the applicant by Art. 4 of Directive 2001/18/EC. Indeed, the Safety Committee is the actual executive institute of safety assessment.

\subsection{Cooperating Authority}

Since GMOs may have a wide range of impacts, in order to fully incorporate knowledge and information from different ministries and reconcile conflicting interests, the InterMinisterial Joint Meeting has been established according to Art. 5 of RMS- AGMO. The Inter-Ministerial Joint Meeting consists of leading officials from ministries of science and technology, environment, health, foreign trade, customs, etc. It is responsible for coordinating significant issues regarding the management of agricultural GMO safety (Art. 
5 of RMS- AGMO). The specific division of regulatory powers is: (1) the MoA is responsible for the safety evaluation and approval of genetically modified crops, the declaration of identification, and the safety management of agricultural GMO imports. (2) the competent provincial agricultural administrative departments are responsible for supervising and managing agricultural GMOs' safety nationwide. (3) the Ministry of Environmental Protection is responsible for assessing and managing environmental pollution involved in the safety assessment of GM products. (4) The State Administration of Quality Supervision, Inspection, and Quarantine is responsible for the inspection and quarantine management

of genetically modified products entering and leaving the country. (5) the Ministry of Health is responsible for supervising and managing the health- and safety-related issues of GM food. (6) the Ministry of Science and Technology is responsible for the technological research and development of genetically modified products. (7) the Ministry of Commerce and Custom is responsible for the importing and exporting management of genetically modified products.

\subsection{Scientific Institute}

The Biosafety Committee for Agricultural GMOs is a scientific institute within MoA, which is composed of experts engaging in biological research, production, further processing, inspection, quarantine, hygiene, and environmental protection (Art. 9 of RMS- AGMO). Likewise, BoFG has also set up an internal scientific institute, i.e., the Biosafety Committee for GM forest trees, specializing in the safety assessment exactly in the same way as the Safety Committee for Agricultural GMOs (Art. 4 of ARMEA-GMF).

ARMSE-AGMO lays down a specific rule for the safety assessment. Safety assessment is designed to assess the dangers or potential risks posed by agricultural GMOs to humans, animals, plants, microorganisms, and the ecological environment. It shall be carried out on a scientific basis and follow the principle of the case-by-case review. Technically, the safety assessment shall be conducted according to the five steps: (1) identify the safety level of the 
recipient organism; (2) identify the type of effect of genetic manipulation on the safety level of the recipient organism; (3) identify the safety level of GMOs; (4) identify the impact of production and further processing activities on the safety of GMOs; (5) and last, determine the safety level of GM products.

In addition to the internal scientific institute, to underpin the scientific nature of decisionmaking, there are external qualified professional inspection organizations or agencies that may or shall be involved in the authorizing process. According to the needs of the safety assessment of agricultural GMOs, the MoA may commission technical testing organizations with testing conditions and capabilities to conduct an independent inspection on the concerned agricultural GMOs to provide a practical basis for subsequent decision-making (Art. 7 of ARMSE-AGMO). Generally, it is to fulfill specific responsibilities, such as carrying out qualitative and quantitative testing, identification and review of agricultural GMOs, issuing test reports and making scientific judgments, researching on testing techniques and methods, and undertaking or participating in the formulation and revision of safety assessment standards and technical regulations (Art. 30 of ARMSE-AGMO). Technical inspection organizations or agencies are obliged to safely destroy the samples used for testing after testing and need to respect the applicant's confidential information. The technical testing organizations or agencies shall meet some necessary conditions to be competent for the testing work.

\subsection{Applicant}

In the process of (preparing for) applying for an authorization of GMOs for various purposes, the applicant has varying degrees and content obligations. On the whole, there are three main types of obligations: the establishment of safety measures, the examination and proposal of the safety level of GMOs, and the submission of specific application materials.

Firstly, an applicant intending to engage in research, testing, production, sale, import, and 
export of agricultural GMOs shall be equipped with safety facilities and measures appropriate to the safety level of the relevant GMOs to prevent the increase of risk from GMO-related activities, and establish an agricultural GMO safety team to be responsible for the internal safety of agricultural GMOs within the unit (Art. 11, 13, 15, 19 and 30 of RMSAGMO). For example, units engaged in the testing and production of agricultural GMOs shall adopt safety control measures and emergency measures for accident prevention, wherein the safety control measures include physical control, chemical control, biological control, environmental control, and scale control ${ }^{97}$ (Art. 35 of ARMSE-AGMO)

Secondly, the GMO safety level shall be identified according to five steps (Art. 9-14 of ARMSE-AGMO) and be enclosed in the application documents. Although the Safety Committee makes the final grade determination of the safety level during the risk assessment process, the applicant must make a proposal on the safety level in advance and submit the related supporting materials to MoA.

Thirdly, before starting GMO-related operations, the applicant shall file the requisite applications in sequential order and submit the prescribed application materials together with supporting evidence. These are obligations as a matter of course for the applicant. As mentioned in section 3.1.2, every GMO shall pass through four stages of authorization

\footnotetext{
${ }^{97}$ Art. 44(14) of ARMSE-AGMO: Physical control measures refer to the use of physical methods to restrict the survival and spread of GMOs and their products outside the experimental area, such as setting up fences to prevent GMOs and their products from escaping from the experimental area or being carried outside the experimental area by people or animals.

Art. 44(15) of ARMSE-AGMO: Chemical control measures refer to the use of chemical methods to restrict the survival, spread or residue of GMOs and their products, such as the disinfection of biological materials, tools and facilities.

Art. 44(16)of ARMSE-AGMO: Biological control measures refer to the use of biological measures to restrict the survival, spread or residue of GMOs and their products, and to restrict the transfer of genetic material from GMOs to other organisms, such as setting up effective isolation and monitoring areas, removing species that can interbreed with GMOs in the vicinity of the experimental area, preventing GMOs from blooming or remove reproductive organs, or adopt measures such as non-flowering period to prevent the transfer of target genes to related organisms.

Art. 44(17) of ARMSE-AGMO: Environmental control measures refer to the use of environmental conditions to restrict the survival, reproduction, spread or residue of genetically modified organisms and their products, such as control of temperature, water, photoperiod, etc.

Art. 44(18) of ARMSE-AGMO: Scale control measures refer to minimize the number of GMOs and their products used for testing or to reduce the area of the testing area, so as to reduce the possibility of widespread spread of GMOs and their products, and to eliminate GMOs and their products more completely in case of unforeseen consequences.
} 
procedure one after the other, i.e., experimental research, restricted field-testing, enlarged field-testing, and productive-testing. Accordingly, the applicant is obliged to apply for the corresponding authorizations. However, in applying for Biosafety Certification, the applicant is, inter alia, required to submit an inspection report, which means that it is obliged to entrust a qualified professional inspecting organization or agency to conduct an independent inspection on the relevant GMO (Art. 15 of RMS- AGMO).

\subsection{Public}

Theoretically, except for GMO labeling, the GMO law does not explicitly formulate any provision to respect the public's right to know or public participation. However, the public's right to know is guaranteed through the "Regulations on the Disclosure of Government Information" in China. Generally, an administrative agency shall take the initiative to disclose governmental information that involves advancing public interest, requires extensive public knowledge, or requires public participation in decision-making (Art. 19 of Regulations on the Disclosure of Government Information).

\subsubsection{Procedure}

\subsection{Research and Restricted Field-testing}

The authorization processes on experimental research and restricted field-testing are relatively simple steps of the procedure compared to the subsequent steps. Specifically, the applicant shall submit a report with the required documents to the competent authority, i.e., MoA in case of agricultural GMOs or BoFG in case of GM forest tree species. As long as the applicant has submitted the qualified application, i.e., supplied to MoA or BoFG the necessary information, it can initiate the relevant activity, including (1) making an experimental research plan or restricted field-testing; (2) identifying the safety levels of agricultural GMOs and supplying the supporting evidence s; (3) providing professional 
technical staff, corresponding laboratory safety facilities, safety management and precautionary measures (Art. 12 and 14 of RMS- AGMO in conjunction with Art. 20 and 21 of ARMSE-AGMO; Art. 8, 9 of ARMEA-GMF). Also, as for restricted field-testing, the summary of the results of experimental research shall be enclosed, which, in particular, contacted molecular identification and target trait detection reports (Art. 21 of ARMSEAGMO; Art. 11 of ARMEA-GMF). Moreover, in the case of restricted field-testing of GM forest tree species, the applicant needs to provide the consent of the landowner or holder of the right to use the land, allowing the applicant to carry out testing on their land.

\subsection{Enlarged Field-testing and Productive testing}

Following the restricted field-testing, enlarged field-testing and productive testing in relation to agricultural GMOs shall be implemented one and the after. However, in contrast to agricultural GMOs, enlarged field-testing and productive-testing in relation to GM forest tree species can be carried out simultaneously (Art. 10 of ARMEA-GMF). Other than that, the authorizing procedure is, by and large, the same.

First of all, if intending to commence enlarged field-testing and productive testing, the applicant shall submit the relevant applications, respectively. The following documents shall be provided: (1) the Application Form of the Safety Assessment, which is designed to present the necessary information on the testing, such as the test plan, a safety assessment according to the safety assessment guidance made by applicant, and so on; (2) the proposal of safety levels of agricultural GMOs and its justifications ; (3) (only appliable to agricultural GMOs) an inspection report issued by a qualified professional technical inspection body of agricultural GMOs, which means that the applicant has to commission one of the technical inspection bodies to conduct an inspection on the testing prior the commencement of corresponding testing; (4) appropriate safety management and precautionary measures; (5) a summary report of the previous testing stage, including the information of the test situation, the impact on the ecological environment, etc.; (6) (only applicable to GM forest 
tree species) the consent of the landowner or holder of the right of use of the land allowing the applicant to carry out testing on their land (Art. 15 of RMS- AGMO and Art. 22 of ARMSE-AGMO; Art. 12 of ARMEA-GMF). In addition, in case of an application for productive testing of agricultural GMOs, samples, control samples, and test methods shall be submitted upon request of MoA (Art. 23 of ARMSE-AGMO). The submitted information in these two stages reflects the fact that the applicant's obligations are more stringent on the grounds that the relevant activity may pose a higher risk than the former two stages. For example, the applicant must commission a qualified professional testing organization or agency to test the relevant agricultural GMOs.

After receiving the application regarding agricultural GMOs, MoA has to organize the Safety Committee for Agricultural GMOs for carrying out a safety assessment on the relevant GMOs and activities (Art. 22 of ARMSE-AGMO). Provided that the corresponding test passes the safety assessment, MoA may grant the authorization. That is, there are two steps here, conducting a safety assessment by the scientific institute and making a final decision by MoA, but the legislation does not specify how the MoA shall weigh the affected interests in the decision-making process. In particular, it is unclear whether the activity of the applicant must be in line with the scientific opinion, or if it is s not, whether there are additional factors that have to or be taken into account by MoA. In practice, while administrative agencies often have broad unfettered authority, they are often willing to hide behind scientific advice rather than take on the burden of assuming the responsibility of their own. Apart from that, there are no more explicit rules to regulate the MoA's decision-making.

Compared to agricultural GMOs, BoFG is not obliged to designate the Safety Committee to carry out a safety assessment, but the standard for authorizing tests related to GM forest tree species is more explicit. According to Art. 13 of ARMEA-GMF, BoFG is obliged to grant consent if the applicant (i) provides a reliable safety assessment; (ii) has security controls in place that meet the security level requirements; (iii) meets the conditions outlined in Art. 8 of ARMEA-GMF, i.e., relating to professional technical staff, corresponding laboratory 
safety facilities, etc.; (iv) complies with the relevant state laws and regulations.

Furthermore, no compulsory time limit has been prescribed for MoA to finalize the decision. However, according to the MoA website instructions ${ }^{98}$, MoA organizes the authorizing process three times every year with the respective deadlines for the applicant to file applications, i.e., March 1, July 1, and November 1. MoA commits itself to complete the safety assessment within six months of the filing application deadline and make the final decision within 20 days after the safety assessment. That is to say, the scientific institute, the Safety Committee for Agricultural GMOs, operates to conduct the safety assessment only three times per year rather than the whole year-round.

In contrast, ARMEA-GMF formulates some basic procedural rules for the authorization of enlarging field-testing, productive testing, as well as biosafety certification and importation relating to GM forest tree species. Specifically, after receiving any of the applications mentioned above, the authority shall issue a written notification stating whether it will review the application or not ${ }^{99}$. In case of a lack of required documents, the authority shall inform the applicant within five days (Art. 20 of ARMEA-GMF). The decision on whether issuing the authorization shall be made within 20 days after the date of accepting to review the application, into which the period of consultation of experts and inspection will not be counted (Art. 22 of ARMEA-GMF). When the statutory period must be prolonged to finalize the decision, confirmed by BoFG, a notification prolonging the reviewing time shall be sent to the applicant (Art. 23 of ARMEA-GMF). The official authorization activities shall be published by virtue of law, which is a rare provision that emphasizes information disclosure (Art. 24 of ARMEA-GMF).

\footnotetext{
${ }^{98}$ Approval to Safety Assessment and Safety Management of Agricultural Genetically Modified Organisms See: http://english.moa.gov.cn/policies/201910/t20191009_297849.html

${ }_{99}$ The authority is entitled to refuse to review the application, but shall explain why it accepts to review or refuses to do so.
} 


\subsection{Biosafety Certification}

Biosafety certification is the core authorization to safeguard biosafety. This is an entitlement and a confirmation, declaring that the GMOs are not dangerous. The procedure of granting the biosafety certification is the most complex one in comparison with other GMO authorizations. After completing productive testing, the applicant can file an application for biosafety certification to MoA or BoFG, accompanied by the prescribed documents, which are almost identical to the stage of productive testing. An exception is that submission of the samples of agricultural GMOs, control samples, and test methods are mandator rather than upon the request of MoA (Art. 16 of RMS- AGMO). However, regarding GM forest tree species, samples, control samples, and test methods are not required.

Once having received the relevant application for agricultural GMOs, MoA shall entrust one of the qualified technical inspection bodies to conduct an independent inspection on the relevant GMOs, and then request the Safety Committee for Agricultural GMOs to carry out the safety assessment (Art. 16 of RMS- AGMO in conjunction with 24 of ARMSEAGMO). If the safety evaluation has been passed, a biosafety certificate of agricultural GMOs may be issued by the MoA. Also, like at the stage of productive testing, no compulsory time limit has been prescribed for examining the application. Yet, MoA announced that there are three times of examinations every year with the respective deadlines for filing the application, March 1, July 1, and November 1 . The safety assessment will be finished within six months after the application deadline, and then a written reply to the applicant will be given to the applicant within 20 workdays. ${ }^{100}$

When authorizing GM forest tree species, the basic procedural rules (mentioned in section 6.3.2.2.2) also apply here. In addition, BoFG has to request the Biosafety Committee to conduct a safety assessment. It may also entrust a qualified inspection institute to conduct

\footnotetext{
${ }^{100}$ Approval to Application for Bio-safety Certificate of Agricultural Genetically Modified Organisms (for Production)

See: http://english.moa.gov.cn/policies/201910/t20191009 297850.html
} 
an inspection test on the relevant GM forest trees. The safety assessment and inspection test period regarding the relevant GM forest tree shall be notified to the applicant within ten days after the date of accepting to review the application. If GM forest tree species pass the safety assessment, BoFG may issue the biosafety certification after taking technical, economic, social, and other factors into consideration (Art. 14 of ARMEA-GMF). The final decision shall be made within 20 days after accepting the application, which excludes the period of safety assessment and inspection test (Art. 21 of ARMEA-GMF).

Generally, the biosafety certificate shall specify the name (number), scale, scope, time limit, responsible person, safety control measures, and other GMO contents (Art. 25 of ARMSEAGMO; Art. 15 of ARMEA-GMF). Units and individuals engaged in the production and processing of agricultural GMOs as well as importing units shall carry out the operation in accordance with the requirements of the biosafety certificate and fulfill the relevant obligations stipulated in the Biosafety certificate.

\subsection{Producing, Processing and Marketing}

Since there are no special procedures for authorizing production, marketing of GMOs, and further processing of GM forest tree species outlined in the GMO law; they will not be described further in this section. The further processing authorization of agricultural GMOs falls under the competence of provincial agricultural authorities. The procedure for authorizing further Processing is relatively simple. Before filing the application, the applicant is obliged to prepare appropriate facilities and measures ${ }^{101}$ (Art. 4 of AREAPAGMO). Moreover, required documents, in particular a copy of the biosafety certificate of

${ }^{101}$ Specifically, the operator has to prepare

(1) Special production lines and closed storage facilities adapted to the processing of agricultural GMOs.

(2) Equipment and facilities for processing waste and inactivation treatment.

(3) Contamination control measures for the conversion of agricultural GMO and non-GMO raw materials for processing.

(4) A comprehensive agricultural GMO processing safety management system. Including: A. raw material procurement, transportation, storage, processing, sales management files; B. job responsibility system; C. Contingency plans for emergencies such as the spread of agricultural GMOs; D. Agricultural GMO safety management team, managers and technicians with knowledge of agricultural GMO safety. 
the relevant agricultural GMO as raw materials of further processing, shall be submitted to the provincial agricultural authority (Art. 5 of AREAP-AGMO). Generally, the provincial authority shall decide and communicate the written decision to the applicant within 20 working days. In certain necessary cases, where the provincial agricultural authority is empowered to make a discretionary to a decision, the authority may organize a panel of experts to evaluate the application materials and request e the panel to conduct a (further processing) site visit and submit a report within a specified period (Art. 6 of AREAPAGMO). Apart from that, there are no explicit criteria on which a decision can be made based.

\subsection{Importing}

As mentioned above, there are seven categories of importing authorizations laid down in RMS-AGMO and one importing authorization in ARMSI-AGMO. Furthermore, ARMSIAGMO prescribes a unified compulsory time limit for MoA for authorizing imported agricultural GMO, i.e., MoA shall make the final decision within 270 days after receipt of application.

In the case of research and testing, the importer shall apply for the corresponding authorization(s), following the same procedure as provided with respect to domestic GMOs (see Sections 6.3.2.2.1-6.3.2.2.2). In addition, imported GMOs shall also meet some "additional conditions," which are the following: (1) The introduced agricultural GMOs have been tested appropriately in a foreign country, and (2) appropriate safety management and preventive measures have been taken (Art. 30 of RMS-AGMO in conjunction with Art. 5, 6 of ARMSI-AGMO). Therefore, in addition to the documents the same that have to be submitted by the applicant of domestic GMOs, the importer shall file the application together with a justification of "additional conditions." 
For the production of GMOs or GM products ${ }^{102}$, the operator is obliged to apply for a series of authorizations, i.e., pass through the whole stages of research, three kinds of different tests, and biosafety certification (for importation) successively, which follow the same procedures a required for domestic GMOs (see 6.3.2.2.1-3). In addition to meeting the essentially same requirements as for domestic GMOs, some "additional conditions" have been prescribed in RMS-AGMO and ARMSI-AGMO. The applicant shall provide relevant supporting materials. These are: (1) the exporting country or region has permitted the marketing of the relevant GMOs, (2) the relevant GMOs or products have been scientifically proven in the exporting country or region to be harmless to humans, plants, animals, micro-organisms, and the ecosystem, (3) appropriate safety management, and preventive measures have been taken (Art. 32 of RMS-AGMO in conjunction with Art. 9 of ARMSI-AGMO).

If the GMOs are intended for further processing or direct consumption, an importer can skip the authorization stages of research and testing and directly apply for the biosafety certification (for importation) from MoA or BoFG. Unlike the domestic GMOs for further processing, the imported GMOs fall under the competence of MoA or BoFG rather than that of the competent provincial authority. Therefore, the importer shall submit the application together with the required documents, which are the same as the documents for obtaining the biosafety certification (for importation) (Art. 12, 13, and 14 of ARMSIAGMO). The biosafety certification (for importation) can be granted if certain conditions are met. Firstly, the GMOs must meet the "additional conditions," which are the same as for the importing authorization for production; secondly, the GMOs have been inspected by a technical inspecting agency ratified by the MoA, and the result confirms that the imported GMOs cause no danger to humans, animals, plants, microorganisms, and the ecological environment, and thirdly, the imported GMOs must pass the safety assessment (Art. 33 of RMS-AGMO in conjunction with Art. 12 of ARMSI-AGMO).

\footnotetext{
102 It should be noted that in addition to seeds, breeding stock, and aquatic seedlings, imported GM products used in the production process, such as pesticides, veterinary drugs, fertilizers, and additives, also fall within the scope of the production purpose, therefore shall pass through the whole authorizing stages until granted a Biosafety Certification (for importation) (Art. 9 of ARMSI-AGMO).
} 
After being granted authorization by MoA or BoGF, the actor must apply for import authorization from Customs straight after (Art. 5). However, Customs will just randomly inspect and quarantine the concerned GM products and verify that they are qualified before granting an importing authorization (Art. 9 of ARMIQEE-GM Products). In fact, ARMIQEE-GM Products does not provide specific inspection and quarantine criteria for Customs to determine whether or not a concerned product qualifies.

\subsection{Summary}

Since the influences of modern risks are to be characterized as wide-ranging, uncertain, high-tech, and value-concerned, ex-ante prevention is far more significant than ex-post remedies. ${ }^{103}$ Regarding the risks and potential risks presented by GMOs, Germany/the EU and China have both established a regulatory framework to regulate the authorization. However, in contrast to German/EU laws, all of China's legislative norms concerning genetic modification have not established any mandatory rules for administrative decisions on GMO-related risk, nor have they designed an open, transparent, science-based, and rational procedure for decision-making. Regarding public participation or information disclosure, there is almost no provision at all. Moreover, there is no separate legislation on GM food in China.

As for the administrative decision-making mechanism, China and the EU have much in common, for example, by adopting a relatively strict precautionary approach to risk. However, they both have some other important different issues. There are two typical differences between China and Germany. Firstly, the scope of responsibility assumed by the government is not the same. German decision-makers have the responsibility of being the primary supervisors, but most of the time, they only review the applicant's documents in writing, i.e., at the "armchair". In contrast, the Chinese government is more deeply

103 The Covid-19 pandemic is a typical example of a risk realization that society cannot afford. 
involved in fact-finding as the basis of the decision-making process, and it is arguably more distrustful of the applicant. Generally, the Chinese government takes on risk assessment tasks independently or commissions testing authorities to conduct the relevant tests. Of course, the possible reason for this difference is the large governmental power and the relatively weak state of judicial control in China. So even with the Chinese government's deep involvement, the scope of review by the judiciary is relatively limited. Secondly, the complexity of the procedure is not the same. In the EU framework, the decision-making process in Germany and the EU is relatively complex. This is mainly due to the complexity of the multi-level structure of governance in a supranational political system such as the EU, where competencies for risk decisions are shared between the Union and the member states and risk decisions need to coordinate the interests of the Union and various member states. Therefore, the procedures are relatively complex. On the other hand, the Chinese system is characterized by strong horizontal parceling of the authorization process into a relatively large number of special types of authorizations. The objective of this approach seems to be the desire to ensure comprehensive control over each part of the whole process of handling GMOs. One can also speak of a radicalization of the step-by-step approach.

Overall, risk decision-making in China and Germany/the EU mainly relies on procedures to ensure the legitimacy of the executive's decisions, but there is a relative lack of substantive decision standards. While this is evident in China, it is less evident in Germany/the EU. In Europe, the precautionary principle is a cornerstone of the decisionmaking process. However, it is not clear how cautious GMO-related decisions need to be and whether and to what extent a risk/benefit or cost-/benefit analysis is permissible in decision-making on GMOs. One can say that both China and Germany/the EU are very cautious about decisions in favor of GMO use, even affecting the whole development of GMO technology. Both the Chinese and German/EU laws are trying their best to balance freedom and safety, but there are limits to the role that the law can play due to the lack of information. The two major tasks of knowledge generation and risk allocation that the law needs to assume are already reflected in the decision-making mechanisms on GMOs. Of course, the law still is confronting many issues that need to be addressed, such as the 
independence and objectivity of experts and public participation and its influence on decision-making. However, ultimately law cannot fundamentally address the uncertainty caused by uncertain risk so that the ultimate solution may be a certain degree of acceptance of uncertainty of risk.

To sum up, this dissertation argues that the law can procedurally guarantee the independence and reliability of experts and guarantees that access to public participation is open. But what the law can do to address public trust and scientific uncertainty risks, in theory, is limited. Due to the lack of in-depth research, the contribution of this dissertation to provide detailed and feasible recommendations for improving the decision-making mechanism is limited. 
Bibliography

Aerni, P., Agricultural biotechnology and public attitudes: an attempt to explain the mismatch between experience and protection. In: Ronald Ross \& Watson VRP (eds), Genetically modified organisms in foods production, safety, regulation, and public health, Elsevier 2015. p. 149.

Adam, Barbara, Beck, Ulrich \& Loon, Joost van (eds.), The Risk Society and Beyond: Critical Issues for Social Theory, London 2000.

Ajami, M, Alimoradi, M. \& Ardekani, MA., Biotechnology: Two decades of experimentation with genetically modified foods. Appl Food Biotechnol Vol. 3:4 (2016), p. 228.

Alberts, Johanna F., van Zyl, Willem H., \& Gelderblom, Wentzel C. A., Biologically based methods for control of fumonisin-producing fusarium species and reduction of the fumonisins. Front Microbiol Vol. 7 (2016), p. 1.

Alexy, Robert, Theorie der Grundrechte, Baden-Baden 1985.

Alexy, Robert, Theorie der juristischen Argumentation, Frankfurt am Main 1996.

Appel, Ivo, Bedeutung außerrechtlicher Wissensbestände für das Management von Unsicherheit, in: Hill, Hermann \& Schliesky, Utz (eds.), Management von Unsicherheit und Nichtwissen, Baden-Baden 2016, p. 116.

Appel, Ivo, Methodik des Umgangs mit Ungewissheit, in: Schmidt-Aßmann, Eberhard (ed.), Methoden der Verwaltungsrechtswissenschaft, Baden-Baden 2004, p. 327.

Appel, Ivo, Staatliche Zukunfts- und Entwicklungsvorsorge: zum Wandel der Dogmatik des öffentlichen Rechts am Beispiel des Konzepts der nachhaltigen Entwicklung im Umweltrecht, Tübingen 2005.

Appel, Ivo, Grenzen des Risikorechts, in: Appel, Ivo, Hermes, Georg \& Schönberger, Christoph (eds.), Öffentliches Recht im offenen Staat: Festschrift für Rainer Wahl zum 70. Geburtstag, Berlin 2011, p. 463.

Appel, Ivo \& Mielke, Sebastian, Strategien der Risikoregulierung: Bedeutung und Funktion eines Risk-Based Approach bei der Regulierung im Umweltrecht, Baden-Baden 2014. Arendt, Hannah, Vita activa oder Vom tätigen Leben (8th edition), München 2010. 
Assmann, Heinz-Dieter, Neue Technologien als Herausforderung, in: Asada, Kazushige (ed.), Das Recht vor den Herausforderungen neuer Technologien: deutsch-japanisches Symposium in Tübingen vom 12. bis 18. Juli 2004, Tübingen 2006, p. 5.

Augsberg, Ino, Von der Gefahrenabwehr zu Risikomanagement und Opportunitätswahrnehmung - Neue Paradigmen im Verwaltungsrecht, in: Peter, Claudia \& Funcke, Dorett, (ed.), Wissen an der Grenze. Zum Umgang mit Ungewissheit und Unsicherheit in der modernen Medizin, Frankfurt, a. M. 2013, p. 209.

Baram, Michael S. \& Bourrier, Mathilde (eds), Governing risk in GM agriculture, Cambridge 2010.

Battis, Ulrich, Bundesbeamtengesetz. BBG. Kommentar(4th edition), München 2009.

Beck, Ulrich, Risikogesellschaft. Auf dem Weg in eine andere Moderne, Frankfurt a. M. 1986.

Beck, Ulrich, Gegengifte. Die organisierte Unverantwortlichkeit, Frankfurt a. M. 1988.

Beck, Ulrich, Risk Society and Provident State, in Scott, L. Szerszynski, B. \& Wynne, B. (eds.), Risk, Environment \& Modernity: Towards A New Ecology, London 1996.

Becker, Bernd, Entscheidungen in der öffentlichen Verwaltung, in: König \& Siedentopf (eds.), Öffentliche Verwaltung in Deutschland, Baden-Baden 1997, p. 435.

Bernstein, Peter L., Against the Gods: The Remarkable Story of Risk, New York 1996.

Beutin, Andreas, Die Rationalität der Risikoentscheidung, Zur Verwendung ökonomischer Kriterien im Risikoverwaltungsrecht, Baden-Baden 2007.

Black, Julia \& Baldwin, Robert, Really Responsive Risk-Based Regulation, Law \& Policy Vol. 32 (2010), p. 181.

Bonß, Wolfgang, Vom Risiko: Unsicherheit und Ungewissheit in der Moderne, Hamburg 1995.

Bora, Alfons, Einleitung: Mehr Optionen und gesteigertes Risiko - Zur Stellung des Rechts in der Risikogesellschaft, Bora, Alfons(ed.), Rechtliches Risikomanagement: Form, Funktion und Leistungsfähigkeit des Rechts in der Risikogesellschaft, Berlin 1999.

Byrne, David, The Genesis of EFSA and the First 10 Years of EU Food Law, in: Alemanno, Alberto \& Gabbi, Simone (eds.), Foundations of EU Food Law and Policy: Ten Years of the European Food Safety Authority, Ashgate, 2014, p. 17. 
Breuer, B., Gefahrenabwehr und Risikovorsorge im Atomrecht, DVBl 1978, p. 829.

Breuer, B., Die internationale. Orientierung von Umwelt- und Technikstandards im deutschen und europäischen Recht, UTR Vol. 9 (1989), p. 43.

Brenner, Michael, \& Nehrig, Anja, Das Risiko im öffentlichen Recht, DÖV 2003, p. 1024.

Brookes, Graham \& Barfoot, Peter, Environmental impacts of GM crop use 1996-2016: impacts on pesticide use and carbon emissions, GM Crops \& Food Vol. 9:3 (2018), p. 1.

Brownsword, Roger \& Yeung, Karen (eds.), Regulating Technologies: Legal Futures, Regulatory Frames and Technological Fixes, Hart Publishing 2008.

Bruening, G. \& Lyons, J., The case of the FLAVR SAVR tomato, California Agriculture Vol.54: 4 (2000), p. 6.

Byungwoog, Park, Wandel des klassischen Polizeirechts zum neuen Sicherheitsrecht: Eine Untersuchung am Beispiel der Entscheidung über sogenannte Online-Durchsuchungen, Berlin 2013.

Bull, Hans Peter, Die Staatsaufgaben nach dem Grundgesetz, Kronberg 1977.

Calliess, Christian, Rechtsstaat und Umweltstaat, Tübingen 2001.

Calliess, Christian, Das Vorsorgeprinzip und seine Auswirkungen auf die Nanotechnologie, in: Reiff, Peter (ed.), Nanotechnologie als Herausforderung für die Rechtsordnung, Berlin 2009, p. 23.

Canenbley, Hans-Wilken, Die Zweckmäßigkeit der Verwendung von Ausschüssen in der Verwaltung, Köln 1968.

Chakraborty, Sweta, The Risk vs. hazard debate: reconciling inconsistencies in health \& safety regulation within the UK and across the EU, https://www.academia.edu/1328407/The Risk Versus Hazard Debate Reconciling Inco nsistencies in Health and Safety Regulation within the UK and across the EU Chatzopoulou, Sevasti, Unpacking the Mechanisms of the EU "Throughput" Governance Legitimacy: The Case of EFSA, European Politics and Society, Vol. 16:2 (2015), p. 159.

Chen, Mao, Shelton, Anthony \& Ye, Gong-yin, Insect-resistant genetically modified rice in China from research to commercialisation, The Annual Review of Entomology 2011, p. 81. Christiansen, T. \& Polak, J., Comitology Between Political Decision-Making and Technocratic Governance: Regulating GMOs in the European Union, EIPASCOPE 2009, p. 
1.

Clive, James \& Krattiger, Anatole F., Global Review of the Field Testing and Commercialization of Transgenic Plants: 1986 to 1995: The First Decade of Crop Biotechnology, International Service for the Acquisition of Agri-biotech 1996.

Clive, James, Global Status of Commercialized Biotech/GM Crops: 2014, International Service for the Acquisition of Agri-biotech (ISAAA) 2015, brief No. 49.

Dadgarnejad, Manouchehr, Kouser, Shahzad \& Moslemi, Masoumeh, Genetically Modified Foods: Promises, Challenges and Safety Assessments, Applied Food Biotechnology Vol. 4: 4 (2017), p.193.

Dagtoglou, Prodromos, Kollegialorgane und Kollegialakte der Verwaltung, Stuttgart 1960 Dagtoglou, Prodromos, Der Private in der Verwaltung als Fachmann und Interessenvertreter, Heidelberg 1964.

Dai, H Y, Miao, Y \& Ji, X Y., Key problems and countermeasures of the safety supervision of genetically modified crops in China, Agricultural economy Vol. 5 (2016), p. 51.

Dale, P., Clarke, B. \& Fontes, E. 'Potential for the Environmental Impact of Transgenic Crops', Nature Biotechnology Vol. 20 (2002), p.571.

Daviesp, Sue, The Consumers' Perspective of EFSA, in: Alemanno, Alberto \& Gabbi, Simone (eds.), Foundations of EU Food Law and Policy Ten Years of the European Food Safety Authority, London 2014, p. 263.

Denninger, E., Gefahreabwehr, in: Lisken, H. \& Denninger, E. (eds.), Handbuch des Polizeirechts (4th edition), München 2007, p. 302.

Delhey, Martin, Staatliche Risikoentscheidungen - Organisation, Verfahren und Kontrolle: Entwicklung eines entscheidungssubjektbezogenen Risikoverständnisses, angewendet auf Ethik-Kommissions-Entscheidungen über klinische Prüfungen bei Menschen, BadenBaden 2014.

Depenheuer, Otto, Das öffentliche Amt, in: Isensee, Josef \& Kirchhof, Paul (eds.), Handbuch des Staatsrechts der Bundesrepublik Deutschland, Vol. III, Demokratie Bundesorgane (3rd edition), Heidelberg 2005, § 36.

Detterbeck, Steffen, Allgemeines Verwaltungsrecht: mit Verwaltungsprozessrecht (17th edition), München 2019. 
Di Fabio, Udo, Entscheidungsprobleme der Risikoverwaltung, NuR 1991, p. 353.

Di Fabio, Udo, Verwaltungsvorschriften als ausgeübte Beurteilungsermächtigung, DVB1 1992, p. 1338.

Di Fabio, Udo, Risikoentscheidungen im Rechtsstaat. Zum Wandel der Dogmatik im öffentlichen Recht, insbesondere am Beispiel der Arzneimittelüberwachung, Tübingen 1994.

Di Fabio, Udo, Gefahr, Vorsorge, Risiko: Die Gefahrenabwehr unter dem Einfluss des Vorsorgeprinzips, Jura 1996, p. 566.

Di Fabio, Udo, Risikosteuerung im öffentlichen Recht, in: Hoffmann-Riem, Wolfgang (ed.), Öffentliches Recht und Privatrecht als wechselseitige Auffangordnungen, Baden-Baden 1996, p. 147

Drews, B., G. Wacke, K. Vogel \& Martens, W. Gefahrenabwehr (9th edition), Heymanns 1986.

Dreyer, Marion \& Renn, Ortwin, EFSA Stakeholder and Public Involvement Policy and Practice: A Risk Governance Perspective, in: Alemanno, Alberto \& Gabbi, Simone (eds.), Foundations of EU Food Law and Policy: Ten Years of the European Food Safety Authority, London 2014, p. 171.

Dreyer, Stephan, Entscheidungen unter Ungewissheit im Jugendmedienschutz: Untersuchung der spielraumprägenden Faktoren gesetzgeberischer und behördlicher Entscheidungen mit Wissensdefiziten, Baden-Baden 2018.

$\mathrm{Du}$ J. et al., Development, challenges and countermeasures for industrialization of genetically modified staple crops in China, Current Biotechnology, Vol. 6: 3 (2016), p. 159. Ehlers, Dirk, Verwaltung und Verwaltungsrecht im demokratischen und sozialen Rechtsstaat, in: Ehlers, Dirk \& Pünder, Hermann (eds.), Allgemeines Verwaltungsrecht, Berlin 2016, p. 1.

Edwards, Marc A. \& Roy, Siddhartha, Academic Research in the 21st Century: Maintaining Scientific Integrity in a Climate of Perverse Incentives and Hyper Competition, Environmental Engineering Science Vol. 34 (2017), p. 51.

Eifert, Martin, Das Verwaltungsrecht zwischen klassischem dogmatischen Verständnis und steuerungswissenschaftlichem Ansatz, VVDStRL Vol. 67 (2008), p. 286. 
Eifert, Martin \& Hoffmann-Riem, Wolfgang, Innovationsverantwortung: Innovation und Recht III, Berlin 2009.

Erichsen, Hans-Uwe, Der Schutz der Allgemeinheit und der individuellen Rechte durch die polizei- und ordnungsrechtlichen Handlungsvollmachten der Exekutive, VVDStRL Vol. 35 (1977), p. 171.

Eichberger, Michael, Gerichtliche Kontrolldichte, naturschutzfachliche Einschätzungsprärogative und Grenzen wissenschaftlicher Erkenntnis, NVwZ 2019, p. 1560.

Engel, Christoph (ed.), Wissen, Nichtwissen, Unsicheres Wissen, Baden-Baden 2002.

European Food Safety Authority. Conclusion on the peer review of the pesticide risk assessment of the active substance glyphosate, EFSA J. Vol. 13: 11 (2015), p. 1

Fassbender, Bardo, Wissen als Grundlage staatlichen Handelns, in: Isensee, Josef \& Kirchhof, Paul (eds), Handbuch des Staatsrechts der Bundesrepublik Deutschland Vol. 4, Aufgaben des Staates, Heidelberg 2006, § 76 .

Fehling, Michael, Kosten - Nutzen - Analysen als Maßstab für Verwaltungsentscheidungen, VerwArch. Vol. 95 (2004), p. 443.

Fehling, Michael, Der Umgang mit Unsicherheit in der ökonomischen Analyse des (Öffentlichen) Rechts, in: Hill, Hermann \& Schliesky, Utz (eds.), Management von Unsicherheit und Nichtwissen, Baden-Baden 2016, p. 203.

Fernandez, M., et al., Glyphosate associations with cereal diseases caused by Fusarium spp. in the Canadian prairies. European Journal of Agronomy Vol. 31: 3, (2009), p. 133.

Fisher, Elizabeth C., Risk Regulation and Administrative Constitutionalism, Oxford 2008. Franzius, Claudio, Modalitäten und Wirkungsfaktoren der Steuerung durch Recht, in: Hoffmann- Riem, Wolfgang, Schmidt-Aßmann, Eberhard \& Voßkuhle, Andreas (eds.), Grundlagen des Verwaltungsrechts, Vol. I, Methoden, Maßstäbe, Aufgaben, Organisation, München 2006, §4 .

Fu, Jianmei \& Li, Biao, Exogenous Cry1Ab/c Protein Recruits Different Endogenous Proteins for Its Function in Plant Growth and Development, Front Bioeng Biotechnol Vol. 8 (2020), p. 685.

Ge, H., et al, Modeling the optimal strategies for mitigating genetically modified (GM) 
wheat contamination risks, Conference: 2016 Agricultural and Applied Economics Association, Boston, p.1

Gerd,Winter, Naturschutz bei der Freisetzungsgenehmigung für gentechnisch veändertes Saatgut, ZUR 2006, p. 456.

Giddens, A., Risk and Responsibility, Modern Law Review Vol. 62 (1999), p. 1.

Götz, Volkmar \& Geis, Max-Emanuel, Allgemeines Polizei- und Ordnungsrecht : ein Studienbuch, München 2017.

Gurlit, Elke, Eigenwert des Verfahrens im Verwaltungsrecht, VVDStRL Vol. 70 (2010), p. 231.

Gusy, Christoph, Rechtsgüterschutz als Staatsaufgabe - Verfassungsfragen der „Staatsaufgabe Sicherheit“, DÖV 1996, p. 573.

Gusy, Christoph, Polizei- und Ordnungsrecht (10th edition), Tübingen 2017.

Hermes, Georg, Das Grundrecht auf Schutz von Leben und Gesundheit: Schutzpflicht und Schutzanspruch aus Art. 2 Abs. 2 Satz 1 GG, Heidelberg 1987.

Heun, Werner, Staatliche Risikosteuerung und Verfassung, RW Vol. 2 (2011), p. 377.

Hill, Hermann, Das fehlerhafte Verfahren und seine Folgen im Verwaltungsrecht, Heidelberg 1986.

Hiller, Petra, Der Zeitkonflikt in der Risikogesellschaft: Risiko und Zeitorientierung in rechtsförmigen Verwaltungsentscheidungen, Berlin 1993.

Hiller, Petra, Probleme prozeduraler Risikoregulierung, in: Bora, Alfons (ed.), Rechtliches Risikomanagement, Berlin 1999, p. 29.

Hofmann, Herwig C.H., Rowe, Gerard C. \& Turk, Alexander H., Administrative Law and Policy of the European Union, Oxford Scholarship Online 2012, https://oxford.universitypressscholarship.com/view/10.1093/acprof:oso/9780199286485.00

\subsection{1/acprof-9780199286485}

Hoffmann-Riem, Wolfgang, „Anscheinsgefahr“ und „Anscheinverursachung“ im Polizeirecht, in: Vogel, Klaus \& Tipke, Klaus (eds.), Verfassung, Verwaltung, Finanzen, Festschrift für Gerhard Wacke zum 70. Geburtstag, Köln-Marienburg, 1972, p. 327.

Hoffmann-Riem, Wolfgang, Innovation und Recht - Recht und Innovation: Recht im Ensemble seiner Kontexte, Tübingen 2016. 
Holoubek, Michael, Die Bedeutung des Amtsermittlungsgrundsatzes, in: Hoffmann-Riem, Wolfgang \& Schmidt-Aßmann, Eberhardt (eds.), Verwaltungsverfahren und Verwaltungsverfahrensgesetz, Nomos 2002, p. 193.

Huang, J. \& Wang, Q. 'Agricultural Biotechnology Development and Policy in China', Journal of Agrobiotechnology Management \& Economics Vol.5: 4 (2002), p. 125.

Huber, Peter M., Risk decisions in German constitutional and administrative law, in: Woodman, Gordon R. \& Klippel, Diethelm (eds), Risk and the Law, Milton Park 2009, p. 21.

Hufen, Friedhelm, Fehler im Verwaltungsverfahren, Nomos 2002.

Isensee, Josef, Das Grundrecht auf Sicherheit. Zu den Schutzpflichten des freiheitlichen Verfassungsstaates. Vortrag gehalten vor der Berliner Juristischen Gesellschaft am 24. November 1982, Berlin 1983.

Ipsen, Jörn, Die Bewältigung der wissenschaftlichen und technischen Entwicklungen durch das Verwaltungsrecht, VVDStRL Vol. 48 (1990), p. 177.

Jaeckel, Liv, Gefahrenabwehrrecht und Risikodogmatik: moderne Technologien im Spiegel des Verwaltungsrechts, Tübingen 2010.

Jansen, Tom, et al., Breaking Down Uncertain Risks for Risk Communication: A Conceptual Review of the Environmental Health Literature, Risk, Hazards \& Crisis in Public Policy Vol. 9: 1 (2018), p.4.

Jähnke, Burkhard, Fließende Grenzen zwischen abstrakter und konkreter Gefahr im Verkehrsstrafrecht, DRiZ 1990, p. 425.

Junk, Judith, Die Rolle des Verwaltungsverfahrens in Deutschland und England: ein Rechtsvergleich exekutiver Wissensgenerierung im gentechnikrechtlichen Freisetzungsverfahren, Baden-Baden 2012.

Kaiser, Anna-Bettina, Generierung und Transfer staatlichen Wissens im System des Verwaltungsrechts, DVBl 2007, p. 169.

Karthaus, Arnim, Risikomanagement durch ordnungsrechtliche Steuerung: Die Freisetzung gentechnisch veränderter Organismen, Baden-Baden 2001.

Kauch, Petra, Gentechnikrecht, München 2009.

Kaufmann, Franz-Xaver: Sicherheit als soziologisches und sozialpolitisches Problem (2nd 
edition), Stuttgart 1973.

King, Alexander \& Schneider, Bertrand, The First Global Revolution, New York 1991.

Klafki, Anika, Risiko und Recht: Risiken und Katastrophen im Spannungsfeld von Effektivität, demokratischer Legitimation und rechtsstaatlichen Grundsätzen am Beispiel von Pandemien, Tübingen 2017.

Klatt, Matthias \& Schmidt, Johannes, Spielräume im Öffentlichen Recht: zur Abwägungslehre der Prinzipientheorie, Tübingen 2010.

Klatt, Matthias \& Schmidt, Johannes, Abwägung unter Unsicherheit, Archiv des öffentlichen Rechts Vol 137 (2012), p. 545.

Kloepfer, Michael, Artikel „Technik“, in: Kunst, Herrmann et al (eds.), Evangelisches Staatslexikon (3rd edition), Vol. 2, Stuttgart, Berlin 1987, p. 3587.

Kloepfer, Michael, Umweltinformationen durch Unternehmen, NuR 1993, p. 236.

Kloepfer, Michael (ed.), Technikumsteuerung als Rechtsproblem: Rechtsfragen der Einführung der Gentechnik und des Ausstiegs aus der Atomenergie ; wissenschaftliche Tagung mit Unterstützung der Fritz Thyssen Stiftung, Berlin 2002.

Kosicki, Michael, Tomberg, Kärt \& Bradley, Allan, Repair of double-strand breaks induced by CRISPR-Cas9 leads to large deletions and complex rearrangements, Nature Biotechnology Vol. 36 (2018), p.765.

Köck, Wolfgang, Risikovorsorge als Staatsaufgabe, Archiv des öffentlichen Rechts Vol. 121 (1996), p.1.

Köck, Wolfgang, Grundzüge des Risikomanagements im Umweltrecht, in: Bora, Einleitung, in: Bora, Alfons (ed.), Rechtliches Risikomanagement, Berlin 1999, p. 129 .

Köck, Wolfgang, \& Kern, Katherina, Rechtliche Strategien zur Bewältigung von Risiken im Stoffrecht - zur konzeptionellen Entwicklung des Stoffrechts, in: Perspektiven des Stoffrechts, UTR Vol. 114 (2012), Berlin, p. 21.

Kritikos, Mihail, Traditional Risk Analysis and Releases of GMOs into the European Union: Space for NonScientific Factors?, European Law Review Vol. (2009), p. 405.

Krüger, Lorenz., The Slow Rise of Probabilism, in: Krüger, Lorenz (ed.), The Probabilistic Revolution, Vol. 1, Cambridge/Mass. 1987, p. 59.

Krüger, Lorenz, Kausalität und Freiheit, Neue Hefte für Philosophie (1992), p. 1. 
Küppers, Bernd Olaf (ed.), Ordnung aus dem Chaos, München/Zürich 1987, p. 1.

Kyburg jr, H. E., Science and Reason, New York/Oxford 1990.

Ladeur, Karl-Heinz, Risikowissen und Risikoentscheidung, Kommentar zu Gotthard Beckmann, Kritische Vierteljahresschrift für Gesetzgebung und Rechtswissenschaft Vol. 74:3/4 (1991), p. 241.

Ladeur, Karl-Heinz, Gefahrenabwehr und Risikovorsorge bei der Freisetzung von gentechnisch veränderten Organismen nach dem Gentechnikgesetz, NuR 1992, p. 254.

Ladeur, Karl-Heinz, Risiko und Recht - Von der Rezeption der Erfahrung zum Prozeß der Modellierung, in: Bechmann, Gotthard (ed.), Risiko und Gesellschaft, Opladen 1993, p. 209. Ladeur, Karl-Heinz, Das Umweltrecht der Wissensgesellschaft: von der Gefahrenabwehr zum Risikomanagement, Berlin 1995.

Ladeur, Karl-Heinz, Risikobewältung durch Flexibilisirung und Prozeduralisierung des Rechts. Rechtliche Bindung von Ungewißheit oder Selbstverunsicherung des Rechts?, in: Bora, Alfons (ed.), Rechtliches Risikomanagement, Berlin 1999, p. 41.

Ladeur, Karl-Heinz, Die Akzeptanz von Ungewissheit: Ein Schritt auf dem Weg zu Einem “Ökologischen” Rechtskonzept, in: Voigt, Rüdiger (ed.), Recht als Instrument der Politik, Heidelberg 1986, p. 60.

Ladeur, Karl-Heinz, Entschädigung für Waldsterben?, DÖV 1986, p. 445

Ladeur, Karl-Heinz, Risikowissen und Risikoentscheidung, KriV (1991), p. 241.

Ladeur, Karl-Heinz, Die Zukunft des Verwaltungsaktes, VerwArch 86 (1995), p. 511.

Ladeur, Karl-Heinz, Privatisierung Öffentlicher Aufgaben und die Notwendigkeit der Entwicklung eines neuen Informationsverwaltungsrechts, in: Hoffmann-Riem. Wolfgang \& Schmidt-Aßmann, Eberhard (eds.), Verwaltungsrecht in der Informationsgesellschaft, Baden-Baden 2000, p. 225.

Laux, Helmut, Der Einsatz von Entscheidungsgremien. Grundprobleme der Organisationslehre in entscheidungstheoretischer Sicht, Berlin 1979.

Lee, Maria, Beyond Safety? The Broadening Scope of Risk Regulation, Current Legal Problems Vol. 62 (2009), p. 24.

Lee, Maria, EU regulation of GMOs: Law and decision making for a new technology, Cheltenham/Northampton 2008. 
Lee, T. Hickey, et al., Breeding crops to feed 10 billion. Nature Biotechnology Vol. 37 (2019), p. 744 .

Leone, Luca, EFSA under Revision: Transparency and Sustainability in the Food Chain, Yearbook of European Law, Vol. 39 (2020), p. 537.

Lepsius, Oliver, Risikosteuerung durch Verwaltungsrecht: Ermöglichung oder Begrenzung von Innovationen?, VVDStRL Vol. 63 (2004), p. 214.

$\mathrm{Li}$, Yunhe, et al. The development and status of Bt rice in China, Plant Biotechnology Journal Vol. 14 (2016), p. 839.

Lofstedt, Ragnar E., Risk versus Hazard: How to Regulate in the 21st Century, European Journal of Risk Regulation Vol. 2 (2011), p. 149.

Luhmann, Niklas, Legitimation durch Verfahren, Neuwied am Rhein 1969.

Luhmann, Niklas, Soziologie des Risikos, Berlin 1991.

Lübbe, Weyma, Die Theorie der adäquaten Verursachung, ZAW 1993, p. 87.

Lübbe-Wolff, Gertrude, Präventiver Umweltschutz - Auftrag und Grenzen des Vorsorgeprinzips im deutschen und im europäischen Recht, in: Bizer, Johann (ed.), Sicherheit, Vielfalt, Solidarität, Baden-Baden 1998, p. 47.

Lyndon, M.L., Risk Assessment, Risk Communication and Legitimacy: An Introduction to the Symposium, Columbia Journal of Environmental Law (1989), p. 291.

Macrory, Richard \& Havercroft, Ian, Environmental Principles in the United Kingdom, in: Macrory, Richard (ed.), Principles of European Environmental Law, Groningen 2004, p. 198.

Möstl, Markus, Die staatliche Garantie für die öffentliche Sicherheit und Ordnung: Sicherheitsgewährleistung im Verfassungsstaat, im Bundesstaat und in der Europäischen Union, Tübingen 2002. .

Möstl, Markus, Gefahr und Kompetenz - Kampfhundeentscheidung, Jura 2005, p. 48.

Murswiek, Dietrich, Die Bewältigung der wissenschaftlichen und technischen Entwicklungen durch das Verwaltungsrecht, VVDStRL Vol. 48 (1990), p. 207.

Murswiek, Dietrich, Die staatliche Verantwortung für die Risiken der Technik, Verfassungsrechtliche Grundlagen und immissionsschutzrechtliche Ausformung, Berlin 1985. 
Norgaard, R.B., Coevolutionary Development Potential, Land Economics Vol. 60 (1984), p. 160.

Vos, Ellen \& Everson, Michelle, Uncertain Risks Regulated, London 2008.

Ossenbühl, Fritz, Vorsorge als Rechtsprinzip im Gesundheits-, Arbeits- und Umweltschutz, NVwZ, 1986, p. 161.

Pache, Eckhard, Tatbestandliche Abwägung und Beurteilungsspielraum: zur Einheitlichkeit administrativer Entscheidungsfreiräume und zu deren Konsequenzen im verwaltungsgerichtlichen Verfahren, Tübingen 2001.

Painter, James, Climate change in the Media: porting Risk and Uncertainty, London 2013. Papier, Hans-Jürgen, Zur veraltungsgerichtliche Kontrolldichte, DÖV 1986, p. 621.

Pardo, José Esteve, Entscheiden und Regulieren in der Ungewissheit. Antworten und Strategien des öffentlichen Rechts, in: Darnaculleta i Gardella, Maria Mercè, Pardo, Josè Esteve, \& Spiecker gen. Döhmann, Indra (eds.), Strategien des Rechts im Angesicht von Ungewissheit und Globalisierung, Baden-Baden 2015, p. 23.

Paciotti, Elena, Law, Uncertainty and Emerging Technologies: Towards a Constructive Implementation of the Precautionary Principle in the Case of Nanotechnologies. Personay Derecho Vol. 62 (2010), p. 15.

Paskalev, Vesco, Losing the Battle, but Winning the War? Standing to Challenge GMO Authorisations and other Acts Concerning the Environment, European Journal of Risk Regulation Vol. 8 (2017), p. 581.

Pieroth, Bodo et al, Polizei- und Ordnungsrecht (6th edition), München 2010.

Polanyi, M., The Tacit Dimension, New York: Garden City. 1966.

Pintado, Citlali, A Taxonomy of EFSA's Scientific Outputs, in: Alemanno, Alberto \& Gabbi, Simone (eds), Foundations of EU Food Law and Policy Ten Years of the European Food Safety Authority, London 2014, p. 29.

Pottschmidt, Axel, Gentechnikrecht, in: Rehbinder \& Schink (eds), Grundzüge des Umweltrechts (5th edition), Berlin 2018, p. 1145.

Poscher, Ralf, Gefahrenabwehr: Eine dogmatische Rekonstruktion, Berlin 1999.

Preuß, Ulrich K., Risikovorsorge als Staatsaufgabe. Die epistemologischen Voraussetzungen von Sicherheit, in: Grimm, D. (ed), Staatsaufgaben, Baden-Baden 1994, p. 523. 
Pünder, Hermann, Verwaltungsverfahren, in: Erichsen, Hans-Uwe \& Ehlers, Dirk (eds.), Allgemeines Verwaltungsrecht (13th edition), Berlin 2006, , p. 365.

Rasmussen, J., Event Analysis and the Problem of Causality, in: Rasmussen, J. (ed.), Distributed Decision Marking - Cognitive Models for Cooperative Work, Chichester 1991, p. 252.

Rehbinder, Eckard, Immissionsschutzrechtlicher Gefahrenbegriff - Beurteilung von Störfällen durch äußere Einwirkungen, BB 1976, p. 1.

Rehbinder, Eckard, Das Vorsorgeprinzip im internationalen Vergleich, Düsseldorf 1991.

Rehbinder, Eckard, Low Doses in Health-Related Environmental Law, in: Streffer et al. (eds.), Low Dose Exposures in the Environment, Heidelberg 2004, p. 325.

Rehbinder, Eckard, et al., Pharming: Promises and risks of Biopharmaceuticals derived from genetically modified plants and animals, Heidelberg 2008, p. 230-231.

Rehbinder, Eckard, Ziele, Grundsätze, Strategien und Instrumente, in: Rehbinder, Eckard \& Schink, Alexander (eds.), Grundzüge des Umweltrechts (5th edition), Berlin 2018, p. 145. Rehbinder, Eckard, Stoffrecht, in: Rehbinder, Eckard \& Schink, Alexander (eds.), Grundzüge des Umweltrechts (5th edition), Berlin 2018, p. 1225.

Reich, Andreas, Gefahr-Risiko-Restrisiko: Das Vorsorgeprinzip am Beispiel des Immissionschutzrechts, Köln 1989.

Reimer, Franz, Das Parlamentsgesetz als Steuerungsmittel und Kontrollmaßstab, in: Hoffmann-Riem, Wolfgang, Schmidt-Aßmann, Eberhard \& Voßkuhle, Andreas (eds.), Grundlagen des Verwaltungsrechts (2nd edition), Vol. 1, § 9, München 2006.

Reinhardt, Materielle Entscheidungsbefugnisse im Gentechnikrecht, Ein Beitrag zur Technikbewältigung durch Recht, NVwZ 2003, p. 1446.

Rengeling, Hans-Werner, Die immissionsschutzrechtliche Vorsorge : Inhalt und Grenzen der Pflicht gemäß § 5 Nr. 2 BImSchG bei Anlagengenehmigung, Baden-Baden 1982.

Renn, Otwin. Concepts of risk: A classification, in: Krimsky, S. \& Golding, D. (eds.) Social Theories of Risk, Praeger 1992.

Rennig, Christoph, Die Entscheidungsfindung durch Schöffen und Berufsrichter in rechtlicher und psychologischer Hinsicht. Empirische, rechtsdogmatische und psychologisch-theoretische Untersuchungen zur Laienbeteiligung an der 
Strafgerichtsbarkeit, Marburg 1993.

Rissler, J. \& Mellon, M., The Ecological Risks of Engineered Crops, Cambridge/Mass. 1996. Rogers, Michael D., Risk analysis under uncertainty, the Precautionary Principle, and the new EU chemicals strategy, Regulatory Toxicology and Pharmacology Vol. 37: 3, p. 370. Roth-Behrendt, Dagmar, A View of EFSA from the European Parliament, in: Alemanno, Alberto \& Gabbi, Simone (eds), Foundations of EU Food Law and Policy Ten Years of the European Food Safety Authority, London 2014, p. 238.

Roth-Behrendt, Dagmar, A View of EFSA from the European Parliament, in: Alemanno, Alberto \& Gabbi, Simone (eds.), Foundations of EU Food Law and Policy Ten Years of the European Food Safety Authority, London 2014, p. 235

Röhl, Hans Christian, Ausgewählte Verwaltungsverfahren, in: Hoffmann-Riem, Wolfgang et al, (eds), Grundlagen des Verwaltungsrechts Vol. II, Informationsordnung, Verwaltungsverfahren, Handlungsformen, München 2008, § 30 .

Sabel, Charles F. \& Zeitlin, Jonathan, Experimentalist Governance in the European Union: Towards a New Architecture, Oxford 2010.

Scheer, Dirk, The Distinction Between Risk and Hazard: Understanding and Use in Stakeholder Communication, Risk Analysis Vol. 34 (2014), p1270.

Schenke, Wolf-Rüdiger, Polizei- und Ordnungsrecht, Heidelberg 2009.

Scherzberg, Arno, Risiko als Rechtsproblem: Ein neues Paradigma für das technische Sicherheitsrecht, VerwArch. Vol. 84 (1993), p. 484.

Scherzberg, Arno, Risikosteuerung durch Verwaltungsrecht: Ermöglichung oder Begrenzung von Innovationen?, VVDStRL Vol. 63 (2003), p. 214.

Scherzberg, Arno, Die Öffentlichkeit der Verwaltung, Baden-Baden 2000.

Scherzberg, Arno, Wissen, Nichtwissen und Ungewissheit im Recht, in: Engel, Christoph (ed.), Wissen, Nichtwissen, Unsicheres Wissen, Baden-Baden 2002, p. 113.

Scherzberg, Arno, Über Klugheit und Rationalität, in: Scherzberg, Arno (ed), Klugheit: Begriff - Konzepte - Anwendungen, Tübingen 2008, p. 25.

Scherzberg, Arno, Risikoabschätzung unter Ungewissheit, ZUR 2010, p. 303.

Scherzberg Arno, Strategien staatlicher Risikobewältigung, in: Hill, Hermann \& Schliesky, Utz (eds.), Management von Unsicherheit und Nichtwissen, Baden-Baden 2016, p. 31. 
Scherzberg, Risikoabschätzung unter Ungewissheit: Preliminary risk assessment im Kontext der Nanotechnologie, ZUR 2010, p. 303.

Scherzberg, Arno, Grundlagen staatlicher Risikosteuerung, in: Albers, Marion (ed.), Risikoregulierung im Bio-, Gesundheits- und Medizinrecht, Baden-Baden 2011, p. 35

Scherzberg, Arno, Risk Communication - Information about and Participation in Legal Decision Making regarding Nuclear and other High-Risk Technologies, Osaka University Law Review No. 62 (2015), p. 85 et seq.

Schmidt, Rolf, Allgemeines Verwaltungsrecht: Grundlagen des Verwaltungsverfahrens; Staatshaftungsrecht (19th edition), Grasberg bei Bremen 2016.

Schmidt-Aßmann, Eberhard, Zur Funktion des Allgemeinen Verwaltungsrechts, DV (1994), p. 137.

Schmidt-Aßmann, Eberhard, Das allgemeine Verwaltungsrecht als Ordnungsidee Grundlagen und Aufgaben der verwaltungsrechtlichen Systembildung, Berlin 2006.

Schmidt-Aßmann, Eberhard, Verwaltungsverfahren und Verwaltungskultur, NVwZ 2007, p. 40.

Schoch, Gerhard, Nachprüfung von Ermessensentscheidungen, in: Schoch, Gerhard \& Schneider, Peter(eds.), Verwaltungsgerichtsordnung, München 2006, § 114.Scholz, Friedrich, Die polizeirechtliche Gefahr, VerwArch. Vol. 27 (1919), p. 1.

Schulte, Martin, How to Deal with Knowledge, Non-Knowledge and Uncertain Knowledge in Law - Illustrated by the Example of the BSE and FMD Conflict, in:

Schuppert, Gunnar Folke, Verwaltungswissenschaft: Verwaltung, Verwaltungsrecht, Verwaltungslehre, Baden-Baden 2000.

Schubert, Gernot, Zwanzig Jahre Gentechnikgesetz - eine Erfolgsgeschichte? NVwZ 2010, p. 871.

Schwabenbauer, Thomas, Einführung in das Recht der grünen Gentechnik - unter Berücksichtigung aktueller Rechtsprechung, NuR 2011, p. 694.

Seckelmann, Margrit, Evaluation und Recht: Strukturen, Prozesse und Legitimationsfragen staatlicher Wissensgewinnung durch (Wissenschafts-)Evaluationen, Tübingen 2018.

Seiler, Hansjörg, Recht und technische Risiken: Grundzüge des technischen Sicherheitsrechts, Zürich 1997. 
Silveira Marques, Antonio, Der Rechtsstaat der Risikovorsorge, Berlin 2018.

Sodan, Helge, Kollegiale Funktionsträger als Verfassungsproblem. Dargestellt unter besonderer Berücksichtigung der Kunststoffkommission des Bundesgesundheitsamtes und der Transparenzkommission, Berlin 1986.

Spieker gen. Döhmann, Indra, Informationsgewinnung im Umweltrecht durch materielles Recht, DVBl. 2006, p. 278.

Spiecker gen. Döhmann, Indra, Rechtliche Strategien und Vorgaben zur Bewertung von Nichtwissen, in: Hill, Hermann \& Schliesky, Utz (eds.), Management von Unsicherheit und Nichtwissen, Baden-Baden 2016, p. 89.

Spiecker gen. Döhmann, Indra, Uncertainty in EU Technology Regulation: How law making and law enforcing matters, in Weimer, M., Caseres, K., \& Eckes, C. (eds.), The Rule of Law in the Technological Age: Challenges and Opportunities for the EU, Collected papers ACELG 6th Annual Conference, 2017, p. 38.

Stein, Reiner, Polizei- und Ordnungsrecht auf einen Blick: für Hessen, MecklenburgVorpommern, Niedersachsen, Sachsen-Anhalt und Schleswig-Holstein : durch Schaubilder mit Erläuterungen, Aufbauschemata, Wörterbuch des Polizei und Ordnungsrechts, Wiesbaden 2019.

Stehr, Nico, Wissen, in: Engel, Christoph (ed.), Wissen, Nichtwissen, Unsicheres Wissen, Baden-Baden 2002, p.17.

Stoll, Peter-Tobias, Sicherheit als Aufgabe von Staat und Gesellschaft Verfassungsordnung, Umwelt- und Technikrecht im Umgang mit Unsicherheit und Risiko, Tübingen 2003.

Tagliabue, Giovanni, The EU legislation on "GMOs" between nonsense and protectionism: An ongoing Schumpeterian chain of public choices, GM Crops Food Vol. 8: 1 (2017), p. 57.

Tan, T., Development path and strategy of commercialization of genetically modified crops in China. Agricultural Technology \& Economy Vol. 1 (2014), p. 22.

Then, Christoph, 30 years of genetically engineered plants -20 years of commercial cultivation in the United States: a critical assessment, 2013. https:/www.testbiotech.org/sites/default/files/TESTBIOTECH\%20Cultivation GE \%20pl ants US.pdf

Thiel, Markus, Die "Entgrenzung" der Gefahrenabwehr: Grundfragen von Freiheit und 
Sicherheit im Zeitalter der Globalisierung, Tübingen 2011.

Tosun, Jale. How the EU Handles Uncertain Risks: Understanding the Role of the Precautionary Principle, Journal of European Public Policy Vol. 20: 10 (2013), p. 1517.

Trute, Hans-Heinrich, Vorsorgestrukturen und Luftreinhalteplanung im Bundesimmissionsschutzgesetz, Heidelberg 1988.

Ulbig, E., Hertel, R. F. \& Böl, G. F. (eds.), Evaluation of Communication on the Differences between "Risk” and "Hazard”, Federal Institute for Risk Assessment, Berlin 2010.

Van Asselt, Marjolein B.A., \& Ellen Vos, Wrestling With Uncertain Risks: EU Regulation of GMOs and the Uncertainty Paradox, Journal of Risk Research Vol. 11 (2008), p. 281.

Van Asselt, Marjolein BA \& Renn, Ortwin, Risk Governance, Journal of Risk Research Vol. 14 (2011), p. 431.

Van Asselt, Marjolein B. A. \& Vos, Ellen, EU Risk Regulation and the Uncertainty Challenge, in: Roeser, Sabine et al. (eds), Handbook of Risk Theory, Heidelberg 2012, p. 1119.

Vos, Ellen \& Everson, Michelle, Uncertain Risks Regulated, Taylor \& Francis 2008

Wahl, Rainer \& Appel, Ivo, Prävention und Vorsorge. Von der Staatsaufgabe zur rechtlichen Ausgestaltung, in: Wahl, Rainer, Prävention und Vorsorge, Bonn 1995, p. 1.

Wahl, Rainer, Risikobewertung der Exekutive und richterliche Kontrolldichte, NVwZ (1991), p. 409.

Wahl, Rainer, Gesetz zur Regelung der Gentechnik, in: Landmann, Rohmer \& Beckmann, Martin, (eds.), Umweltrecht Vol. II, § 1 GenTG, München 1994.

Walker, Warren E., et al, Defining Uncertainty: A Conceptual Basis for Uncertainty Management in Model-Based Decision Support." Integrated Assessment Vol. 4: 1 (2004), p.

5.

Wang, Y.M., et al, Influence of transgenic hybrid rice expressing a fused gene derived from cry $1 \mathrm{Ab}$ and cry1Ac on primary insect pests and rice yield, Crop Protection Vol. 29 (2010), p.128.

Weimer, Maria, 'Risk Regulation and Deliberation in EU Administrative GovernanceGMO Regulation and Its Reform', European Law Journal Vol. 21 (2015), p. 622

Weimer, Maria \& Marin, Luisa, The Role of Law in Managing the Tension between Risk 
and Innovation: Introduction to the Special Issue on Regulating New and Emerging Technologies, European Journal of Risk Regulation Vol. 7: 03 (2016), p. 469.

Weimer, Maria, The Origins of "Risk" as an Idea and the Future of Risk Regulation, European Journal of Risk Regulation Vol. 8: 1 (2017), p. 10.

Weimer, Maria, et al, The Rule of Law in the Technological Age Challenges and Opportunities for the EU Collected Papers. Amsterdam Centre for European Law and Governance, Research Paper No. 2017-02.

Wiener, Jonathan B., The Regulation of Technology, and the Technology of Regulation, Technology in Society Vol, 26 (2004), p. 483.

Wißmann, Hinnerk, Generalklauseln: Verwaltungsbefugnisse zwischen Gesetzmäßigkeit und offenen Normen, Tübingen 2008.

Wollenschläger, Burkard, Wissensgenerierung im Verfahren, Tübingen 2009.

Wolff, Hans, Bachof, Otto \& Stober, Rolf, Verwaltungsrecht (6th edition) Vol. II, München 2000.

Wynne, B., Risk and Social Learning: reification to engagement, in: Krimsky, S. \& Golding, D. (eds.), Social Theories of Risk, Praeger 1992, p. 275.

Xiang Wen, Risk Governance of GMOs in the EU and in China, Ghent University. Faculty of Law, Ghent, Belgium, 2013. See: https://biblio.ugent.be/publication/3160785

Yang, W., 'Regulation of GMOs in China', Review of European Community and International Environmental Law Vol. 12: 1 (2003), p. 99.

Zhang C, Wohlhueter R, \& Zhang H., Genetically modified foods: A critical review of their promise and problems. Food Sci Hum Well Vol. 3: 5 (2016), p. 116

Zhang, Q., 'China: Agricultural Biotechnology Opportunities to Meet the Challenges of Food Production', in: Persley, G. \& Lantir, M. (eds.), Agricultural Biotechnology and the Poor, Consultative Group on International Agricultural Research, Washington, D.C. 1999, p. 46.

Zhao, Jennifer \& Ho, Peter, A developmental risk society? The politics of genetically modified organisms (GMOs) in China, International Journal of Environment and Sustainable Development, Vol. 4 : 4 (2005), p. 370

Zhao, Peng, The Administrative Law's Response to Risk Society: Focusing on Health and 
Environmental Risk Regulation, Beijing 2018.

Zivier, Ezra, Rechtsprobleme des Gentechnikgesetzes im Bereich der Gefahrenabwehr bei legalen Vorhaben, Berlin 1995. 